University of South Florida

DIGITAL COMMONS

Digital Commons @ University of

@ UNIVERSITY OF SOUTH FLORIDA

South Florida

Integrative Biology Books

Integrative Biology

1891

\title{
Morphological Studies on the Echinoderms: A Translation of Études Morphologiques sur les Échinodermes
}

Lucien Cuénot

John M. Lawrence

University of South Florida, lawr@usf.edu

Follow this and additional works at: https://digitalcommons.usf.edu/bin_books

\section{Recommended Citation}

Cuénot, L. (2020). Morphological Studies on the Echinoderms: A Translation of Études Morphologiques sur les Échinodermes (J. M. Lawrence, Trans.). Herizos Press, Tampa.

This Book is brought to you for free and open access by the Integrative Biology at Digital Commons @ University of South Florida. It has been accepted for inclusion in Integrative Biology Books by an authorized administrator of Digital Commons @ University of South Florida. For more information, please contact digitalcommons@usf.edu. 
Cuénot, L. 1891. Études morphologiques sur les Échinodermes Archives de Biologie. 11. 313-680.

Cuénot, L.1891. Morphological studies on the echinoderms. Translated by John M. Lawrence. (C) Herizos Press, Tampa. John M. Lawrence. 


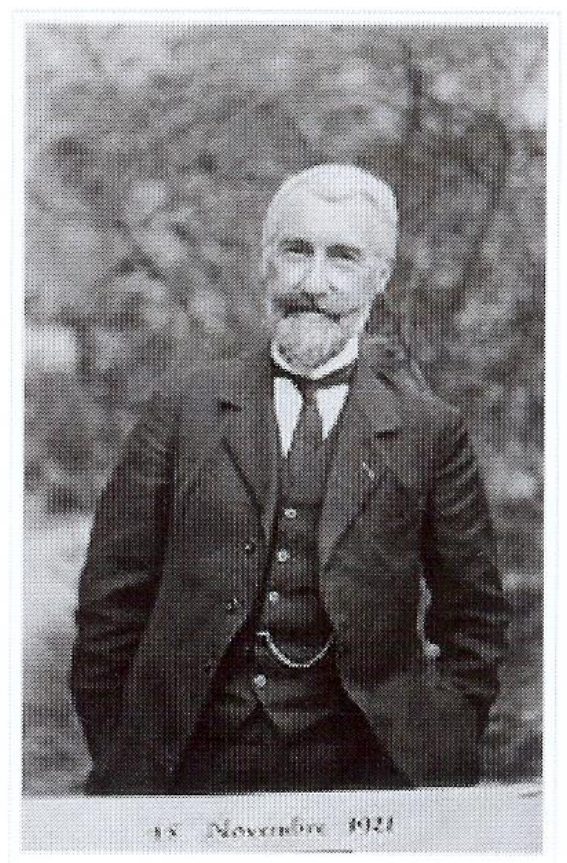

\section{Lucien Cuénot}

Lucien Claude Jules Marie Cuénot was born in Paris on 21 October, 1866 and died in Nancy on 7 January, 1951. He was elected to the Academy of Science in 1932. An account of his life and work was given in a lecture to the Academy by Robert Courrier, Perpetual Secretary of the Academy in 1952. He called Cuénot a biologist of exceptional value who honored the Academy as a member.

Cuénot entered the Sorbonne in 1883. Intially interested in paleontology, the influence of Lacaze-Duthiers directed him to zoology. He received his licentiate in natural sciences in 1885 and the doctorate in natural sciences only two years later in 1887 at the age of 21, both at Paris. He then took the position of préparateur of anatomy and comparative physiology in the Faculty of Science at Paris where he also began studies in medicine. After one year he took the position of maittrise de conferences at Lyon and then joined the Faculty of Sciences of Nancy in 1890. He became chair of zoology in 1898. He stayed in that position until his retirement in 1937. Courrier said Cuénot was very affable to the "humble" but was sometimes biting to his colleagues.

After his thesis on starfish, Cuénot published numerous papers on the anatomy and physiology of echinoderms and other invertebrates with an experimental approach. After his retirement, he published (1948) “Anatomie, éthologie et systématique des Échinodermes" in Traité de Zoologie.

Cuénot is perhaps best known in the scientific world for his work with genetics. According to Hickman and Caims (Genetics. 163, 839-841, 2003), Cuénot was the first to demonstrate that Mendel's laws of inhertance apply to animals as well as plants. They gave an account of Cuénot's contribution. As soon as Mendel's work was rediscovered with plants in 1900, Cuénot asked the question whether Mendel's rules applied to animals. He established a mouse colony and reported in 1902 that inheritance of coat color followed Mendel's laws. Cuénot continued his genetic studies until 1914, when he had to abandon his mouse colony with the invasion of Nancy by German troops. He was over 50 when the war ended and returned to his physiological and zoological studies. 



\title{
Morphological studies on the echinoderms
}

\author{
BY \\ L. CUÉNOT \\ Lecturer of a complementary course of Zoology at the Factulty of Sciences of Nancy \\ PLATES XXIV TO XXXI. \\ INTRODUCTION
}

Echinoderms have been the object of a considerable number of works, mainly monographic, that have little by little clarified the structure and the importance of the different organic systems. From this point of view, agreement is not far from being definitively established. But the morphological studies are far from being as advanced. There is not, as it were, concerted works on echinoderms from a comparative point of view. It is this gap that I try to fill now.

I previously studied asteroids and ophiuroids (1887-88). In later years I have revised the work related to holothuroids and echinoids, laying a little to the side the crinoids for good reason as we shall see later. I have followed moreover as near as possible the transformation of the systems and organs in the different groups, as well as their organogenesis, from the moment where the echinoderm separates itself from the larva and is free up to the adult state. I hope to have found some new facts and above all to have simplified the general concept of the echinoderm. The gaps that I have had to leave and the errors that I have made should be excused in consideration of the considerable work I have undertaken.

A general work on echinoderms would perhaps appear out of place - and presumptuous - when Ludwig has published his vey complete studies in "Bronn's Thierreichs". I want to take a comparative point of view, absolutely different from that of Ludwig. His "Echinodermen" constitutes a true bibliographic monument, to which it will always be necessary to refer.

de Lacaze-Duthiers has kindly sent me fresh and preserved asteroids and ophiuroids from the stations at Banyuls and Roscoff. I express here all my gratitude to him and also to Friant, professor of the Faculty of Sciences of Nancy, whose liberality has permitted me to obtain a certain number of interesting species that are not found on our coasts. I thank very much Herbert Carpenter, Danielssen (director of the Bergen Museum, Brunotte (associated with the Superior School of Pharmacy of Nancy) for the specimens of crinoids and holothuroids that they have kindly given me, and finally to my excellent friends, Doctors Saint-Remy and Hecht, who have obligingly made various histological preparations at Roscoff.

Species studied. - Among the asteroids, in addition to the species of our coasts and the Red Sea cited in my first work ${ }^{1}$, I have studied Asterias tenuispina Lamarck (Mediterranean), remarkable

\footnotetext{
${ }^{1}$ Contribution à l'étude anatomique des Astérides, Arch. Zool. Exp., 2e série, vol. V and following, 1887 (see p. 134).
} 
for its reproduction by fission. Among the ophiuroids, nearly all of the species from the coasts of the Atlantic Ocean and of the Mediterranean (Roscoff and Banyuls), Ophiactis virens Lütken (Gulf of Naples), which also reproduces by division, a certain number of ophiuroids and an Astrophyton from the Red Sea (mission of Dr. Faurot). Among the urchins, the regulars and spatangoids common on our coasts and three clypeasteroids, Echinocyamus pusillus Gray (specimens from the Mediterranean), a specimen of Echinodiscus biforis A. Agassiz (Red Sea, mission of Dr. Faurot) and one of Peronella orbicularis A. Ag.

Among the crinoids, I have studied Antedon rosacea Linck (Roscoff and Banyuls) and the arms of various species collected by the Challenger, for which I am obliged to $\mathrm{H}$. Carpenter (Actinometra nobilis and solaris, Antedon, Escherichtii, Pentacrinus Wyvile-Thomsoni and docorus, as well as the stalk and the cirri of the latter species.

Among the holothuroids, I have had available Cucumaria Planci v. Marenzeller and cucumis Sars from the Mediterranean; Cucumaria Lacazii Hérouard (from Roscoff)'; a species lacking Cuvierian tubules, Holothuria impatiens Gmelin (Mediterranean); and an elasipod in perfect state of preservation, Elpidia glacialis Théel, that Danielsen has kindly sent me.

Among the synaptids, I have studied only Synapta inhæerens Düb. and Koren (Atlantic Ocean).

Synonymy. - Ludwig gave in 1879 a list of all the species from the Mediterranean. I have adopted all the names he used. The reader should certainly refer to this work for the synonymy (see also Carus, Prodromus Faunæ Mediterranæ, part 1, 1884, Stuttgart).

For the asteroids, I have followed Perrier (Revision des Stellérides du Museum), for the echinoids A. Agassiz (Revision of the Echini); I shall refer especially to the list of extant species that he gave in his Report of the Challenger (page 208).

For the other groups, I have referred to the most authoritative specialists, H. Carpenter, Lyman, Lampert, etc.

Techniques. - I have naturally used all methods of study, but especially serial sections that give invaluable certain results. Because of the hardness of the connective tissue, it is difficult to use anything but the microtomes of Yung or Schanze with the dérouleur of Naples that is indispensable.

As a histological fixative, it makes no difference if alcohol, mercuric chloride, picric acid, etc. are used. Echinoderms are preserved indefinitely in excellent state in $90 \%$ alcohol. Flemming's chromo-aceto-osmic acid solution usually gives very good results for cytological studies. Prolonged immersion in $1 \%$ osmic acid (24 hours), then in distilled water is recommended for dissociation.

It is nearly always necessary to decalcify. Here is the procedure I use: the fixed tissue is immersed in $70 \%$ alcohol with some drops of hydrochloric acid or picro-nitric acid that is renewed as many times as necessary in a way that decalcification is slow and complete. After the acid bath, the tissue is immersed in absolute alcohol at least twelve hours under a partial vacuum. In this way, no gas bubbles remain in the tissue. It is much preferable to stain in bulk in order to have a selection. I often use a double stain that I have borrowed from Remy Perrier and Bernard on the prosobranchs (Ann. Sc. Nat., $7^{\circ}$ série, vol. 8, 1889; vol. 9, 1890) and which has given me excellent results. The decalcified and washed tissue is stained either with ammonium picrocarmine or boric acid picrocarmine. It is then dehydrated by immersion several hours in $70 \%$ to $90 \%$ alcohol, then

\footnotetext{
${ }^{2}$ Cucumaria Lacazii has been placed by Hérouard into the genus Colochirus. As H. Ludwig has kindly informed me in a special letter this species completely lacks the characters of the genus Colochirus (buccal area divided into five rays; tube feet of the bivium transformed into simple papillae). As Hérouard and others remarked, this species is very near various exotic Cucumaria described by Ludwig. He also agrees to their integration into this genus.
} 
immersion from 6 to 12 hours in absolute alcohol containing a little methylene blue (to give a celestial blue color). Methylene blue has a very remarkable affinity for most connective tissues and for certain cellular elements (holothuroids, synaptids, asteroids) that take a beautiful blue or violet color. After removal from the blue-colored alcohol, the tissue is put into paraffin saturated toluene, then to melted paraffin at nearly $50{ }^{\circ} \mathrm{C}$. It is necessary to leave it in the melted paraffin for several days for inclusion to be perfect. Sections are glued on the slide with the help of Schällibaum's collodium, washed in toluene and mounted in Canada balm.

For routine processing, I have also employed a process of staining on sections that give valuable histochemical indications. It was inspired by the procedure of Biodi (see Zeitschrift für wiss. Mikroskopi, vol. V, number 4, 1888, p. 520). Saturated solutions in distilled water are made of methyl green, orange III, and acid fuschin ${ }^{3}$. These solutions are mixed in the proportions of one part of fuchsine, two parts of orange and three parts of methyl green. This produces a very intense red mahogany liquid. Approximately $1 \mathrm{ml}$ of this is added to $150 \mathrm{ml}$ of distilled water in a glass container

The fixed and decalcified preparations are firm and included as usual. They are glued on slides with Mayer's glycerinated albumin. After placing the sections into toluene and alcohols successively, they are immersed a variable time (12 to18 hours) in the prepared stain. When staining appears sufficient, they are rapidly dehydrated and mounted in balm. The selections are very variable and of great detail. All the nuclei are green, all those that are proteinaceous (nerves, globules with hemoglobin, cells, muscles) are colored orange, the color having a remarkable intensity in reserve organs that accumulate protein (when the selection is very clearly orange, one can be nearly certain that it is protein, but I believe that there are some that are not stained). Connective tissue is weakly stained pink by fuchsine. It is necessary naturally to use this procedure only to define doubtful tissues and organs and then modify it to find the appropriate concentration of stain. The method is especially useful for histochemical information.

Plan of work. - There remains to indicate the ideas by which this work is conceived. I have undertaken to compare all the systems of organs of echinoderms in order to deduce their evolutionary path, the real homologies and adaptations that developed in the course of centuries. This is a point too often forgotten in morphology: two organs, in different types, are homologous only when they derive from the same ancestral organ. Without this condition sine qua non, whatever be their resemblances, there are no homologies possible. These are analogies due to an adaptation to the same goal, to a phenomenon of convergence. Darwin has made this distinction clear and he gave a striking example. The electrical organs of various fish are surely not homologous because no one suggests they derive from the same ancestral stock: they are, following Darwin's expression, analogous variations. Ray Lankester has proposed to call homogenic modifications of a common ancestral structure and homoplastic those that result from an adaptation to the same goal without hereditary relation.

It is thus indispensable, in morphological research, to penetrate as deeply as possible into the organogenesis and to rely on them much more than on superficial resemblances and relations. I have not failed to do this for the echinoderms. Many excellent works have given me valuable indications that I have completed as much as in my power.

These investigations are divided naturally into two parts. In the first, I analyze in succession the different organ systems, recall as briefly as possible the facts already known in order to develop more extensively on new or discussed points. I deliberately leave crinoids a little to the side. In

\footnotetext{
${ }^{3}$ All these products obtained from Grüber, Leipzig.
} 
fact, these animals, basically known only from Antedon, are too far from the original stock and too evolved for the information they would give to have a great phylogenic value.

In the second part, I will make a synthesis, search to establish the genealogy of the phylum by comparing the different stages taken by the organs. I will rely on the fundamental biogenetic law (correspondence of phylogeny and ontogeny), interpreted in a sense more precise than usual.

\section{BIBLIOGRAPHY}

I give here a simple numbered index of the works cited in this memoir. Ludwig has published a nearly complete bibliography of echinoderms up to 1879 (103), and of holothuroids up to 1889 (114). H. Carpenter has given, in his Challenger Report, the complete bibliography of neocrinoids up to 1884 (21). I have to state that the admirable Berichte of Naples, whose section on echinoderms was edited successively by Ludwig, Hamann and H. Carpenter, has been of great use and that I used much of the information.

1. Agassiz, AleX. On the embryology of Echinoderms. Memoirs of the Americ. Acad., vol. 9, 1864

2., --- Revision of the Echini. Illust. Catal. Of the Mus. Of comp. zool. At Harvard College, $\mathrm{n}^{\circ}$ 7, Cambridge (Mass.), 1872-74.

3. --- Report on the Echinoidea. The voyage of H. M. S. Challenger, vol. 3, 1881, London.

4. --- ANKUM (VAN). Jets omtrent de generatic-organen bij Echinus esculentus, Tijdschr. der nederl. dierk. Vereenigung, t. 1, 1872, p. 52.

5. ApostolidÉS. Anatomie et developpement des Ophiures, Arch. Zool. Exp., $1^{\text {re }}$ série, t. 10, 1882, p. 121.

6. AYERS. On the Structure and Function of the Sphaeridia of the Echinoidea, Quart. Journ. Mic. Sc., vol. 26, 1886, p. 89.

7. BARRANDE. Système silurien du centre de la Bohême, $1^{\text {re }}$ partie vol. 7, Ordre des Cystidés (ouvrage posthume, Prague, 1887).

8. BeDDARD. Striated muscles in Echinida, Ann. Mag. Nat. Hist. vol. 17, 1886, p. 428.

10. BELL, JEFFREYS. Note on an abnormal (quadriradiate) specimen of Amblyspneustes formosus, Journ. Linn. Soc. London, Zool., t. 15, 1880, p. 126.

11. ---. Note on the Echinoderm-Fauna of the Island of Ceylaln, together with some observations on heteractinism., Ann. Mag. Nat. Hist., vol. 10, 1882, po. 218.

12. --- Note on the spicules found in the ambulacral tubes of the regular Echinodea, Journ. Roy. Mic. Soc., t. 2, 1882, p. 297.

13. ---. Studies on the Holothuroidea. On the structural Characters of the Cotton spinner and especially of its Cuvierian Organs, Proc. Zool. Soc. London, 1884, p. 827.

14. --- Echinodermata of Deep-Water of the S. W. Coast of Ireland, Ann. Mag. Nat. Hist., t. 4, 18889 , p. 432.

15. BRock. Die Ophiuridenfauna des indischen Archipels, Zeits. für wiss. Zool., bd.47, 1888, p. 465.

16. BURY. The early stages in the development of Antedon rosacea. Phil. Trans. of the Roy. Soc. of London, vol. 179, 1888, p. 257.

17. --- Studies in the embryology of the Echinoderms, Quat. Journ. Misc. Sc., vol. 29, 18889, p.490. 
18. CARPENTER, H. On the oral and apical systems of Echinoderms, Quat. Journ. Mic. Sc., vol. 18,1878 et $19,1879$.

19. --- The minute anatomy of the brachiate Echinoderms, Quat. Journ. Mic. Sc., vol. 21, 1881, p. 169.

20. --- On the apical system of the Ophiurids, Quat. Journ. Mic. Sc., vol. 24, 1884, p. 4.

21. --- Report on the Crinoidea. The Voyage of H. M. S. Challenger, vol. 11, 1884.

22. --- The morphology of Antedon rosacea, Ann. Mag. Nat. Hist., t. 19, 1887, p. 19

23. --- On the development of the apical plates in Amphiura aquamata, Quat. Journ. Mic. Sc., vol. 28,1887, p.313.

24. --- On the supposed presence of symbiotic algae in Antedon rosacea, Quat. Journ. Mic. Sc., vol. 27, 1887, p. 379.

25. --- Report on the Crinoidea, part 2. The Comatulae. The Voyage of H. M. S. Challenger, vol. 26, 1888.

26. --- On certain points in the anatomical Nomenclature of Echinoderms, Ann. Mag. Nat. Hist., vol. 6,1890, p. 1.

27. Colton et Garman. Some notes on the development of Arbacia punctulata, Studies Biol. Labor. Johns Hopk. Univ., vol. 2, 1882, p. 247.

28. Cuenot, Contribution à l'étude anatomique des Astérides, Arch. Zool. exp., $2^{\text {me }}$ série, t. $6^{\mathrm{a}}$, $2^{\text {me }}$ mémoire, 1887.

29. --- Etudes anatomiques et morphologiques sur les Ophiurea, Arch. Zool. Exp., $2^{\text {me }}$ série, t. 6, 1888 , p. 33.

30. --- Sur le système madréporique des Echinodermes, Zool. Anz., no 337, 1890, p. 315.

31. --- Le système nerveux entérocalien des Echinodermes, Comptes rendus Ac. Sc. Paris, t. 111, $\mathrm{n}^{\circ} 22.190-$. [/ 937/

32. --- Etudes sur le sang et les glandes lymphatiques (Invertébrés). Arch. Zool. exp., $2^{\text {me }}$ série, t. 9, 1891.

33. --- Etudes morphologiques sur les Echinodermes, note préliminaire, Arch. Zool. exp., $2^{\text {me }}$ série, t. 9, 1891, Notes et Revue.

34. Cuenot et JAnet. Note sur les orifices génitaux multiples, sur l'extension des pores madréporique hors du madréporite et sur la terminologie de l'appareil apical chez les Echinides. Bull. Soc. Géolog. de France, t.19, séance du 2 février 1891.

35. DANIELSSEN ET KoREN. Observations sur le développement des Holothuries. Fauna littoralia Noravegia (Sars, Danielssen et Koren), $2^{\text {me }}$ liv., Bergen, 1856.

36 --- Holothuroidea. Den Norske Nordhavs-Expedition 1876-78, Zoology, Christiania, 1882.

37. --- Astseroidea. Id. 1884.

38. DENDY. On the regeneration of the visceral mass in Antedon rosaceus, Stud. Biol. Lab. Owens College, Vol. 1, 1886, p. 229.

39. DoHRn. Mittheillungen aus und über die zoologische Station von Neapel, Zeits. Für wiss. Zool., t. 25, 1875, p. 457.

40. DunCAN. Remarks on Dr. Hamann's Researches in the Morphology of the Echinoidea, Ann. Mag. Nat. Hist., vol. 18, 1886, p. 66.

41. --- On the Ophiuridae of the Mergui Archipelago, Journ. Linn. Soc. London, Zool., vol.21, 1887, p. 85.

42. --- Revision of Genera and great groups of Echinoidea, Journ. Linn. Soc. London, Zool., vol. 28,1889, p. 1. 
43. DunCan et Sladen. On the family Arbaciadae, Gray, part 1. The morphology of the test in the genera Calopleurus and Arbacia, Journ. Linn. Soc. London, Zool., vol. 19, 1885, p. 25.

44. --- On some points in the Morphology and classification of the Salinida, Ann. Mag. Nat. Hist., vol. 19, 1887, p. 117.

45. DuRHAM. The emigration of amaboid corpuscles in the Starfish, Proc. of the Roy. Soc., vol. 43, 1888, p. 327.

46. --- Note on the madreporite of Cribella oculata, id., p. 330.

47. EBNER. Skelettheile des Kalkschwämme, Sitzungsber. der K. Akad. der Wiss., bd. 95, 1887, p. 55.

48. FEWKES. On the development of the calcareous plates of Amphiura, Bull. Mus. Comp. Zool. At Harvard Coll., vol. 13, 1887, p. 107.

49. --- On the development of the calcareous plates of Asterias, Bull. Mus. Comp. Zool. at Harv. Coll., vol. 17, 1888, p. 1.

50. FoetTINGER. Sur l'existence de l'hémoglobine chez les Echinodermes, Arch. De Biologie, t. 1,1880, p. 405.

51. --- Sur la structure des pédicellairs gemmiformes de Sphorechinus granularis et ai'austres Echinide, Arch. de Biologie, t. 2, 1881, p. 455.

52. FöRSTE. The power of motion in Crinoid stem, Amer. Natur., vol. 18, 1884, p. 5.

53. Fredericq. Contributions à l'étude des Echinides, Arch. Zool. exp., $1^{\text {re }}$ série, t. 5, 1876, p. 483.

54. GEDDES. Observations sur le fluide péiviscéral des Oursins, Arch. Zool. exp., $1^{\mathrm{re}}$ série, t. 8, 1879, p. 483.

55. GEDDES ET BeDdARD. On the histology of the Pedicellaria and the muscles of Echinus sphara, Trans. Roy. Soc. Edinb., vol. 20, 1881, p. 392.

56. Giard. Sur certaines monstruosités de l'Asteracanthion rubens, Comptes Rendus Ac. Sc. Paris, t. 85, 1877, p. 973.

57. --- Particularités de reproduction de certains Echinodermes, Bull. Sc. du départ. Du Nord, $2^{\text {me }}$ série, t. 1, 1878, p. 296.

58. --- L'automie dans la série animale, Revue Scientifique, Paris, t. 39, 18887, p.629.

59. --- La Castration parasitaire. Bull. Scient. de la France et de la Belgique, t. 19, 1888, p. 629. 60. GIESBRECHT. Der feinere Bau der Seeigelzählne. Morph. Jahrb., bd. 6, 1880, p. 79.

61. GREEFF. Ueber den Bau der Echinodermen, Sitzber. d. Gesellsch. z. Beförderung der ges. Naturw. zu Marburg. 1872-76-79.

62. GRIFFITHS. Further Researches on the Physiology of the Invertebrata, Proc. Roy. Soc. London, vol. 44, 1888, p. 826.

63. HAACKE. Ueber eine Abnormität am Darm von Asteracanthion rubens, Zool. Anz. $\mathrm{n}^{\circ} 44$, 1879, p.641.

64. --- Zur Morphologie der Seeigelschale, Zool. Anz, Jahrg. 8, 1885, p.490.

65. --- Die Radiäthiernatur der Seeigel, Biol. Centralb., bd. 7, 1887, p.289.

66. HAMANN. Beiträge zur Histologie der Echinodermen, Zeits. für wiss. Zool., bd.39, 1883, p. 145 et p. 309.

67. --- Id. Heft 1. Die Holothurien. Jena, 1884.

68. --- Id. Heft 2. Die Asteriden. Jena, 1885.

69. --- Id. Heft 3. Anatomie und Histologie der Echiniden und Spatangiden. Jen. Zeits. Naturw., bd. 21,18887, p.87. 
70. --- Die Wandernden Urkeimzellen und ihre Reifungstätten bei den Echinodermen, Zeits. für wiss. Zool., bd. 46, 1888, p. 80.

71. HARTOG. The true nature of the "Madreporic system" of Echinodermata, with remarks on Nephridia, Ann. Mag. Nat. Hist., vol. 20, 18887, p.321.

73. HEROUARD. Recherches sur les Holothuries des Côtes de France, Arch. Zool., exp., $2^{\text {me }}$ série, t.7, 1889, p. 535.

74. HindE. Description of a new species of Crinoids with articulating spines, Ann. Mag. Nat. Hist., vol. 15, 1885, p. 157.

75. HofFMANN. Zur Anatomie der Echinen und Spatangen, Niederl. Arch. für Zool., bd. 1, 1871, p. 11.

76. --- Zur Anatomie der Asteriden, id, bd. 2, 1875, p. 1.

77. Howell. Obesrvations upon the blood of Limulus polyphemus, Callinectes hastatus and a species of Holothurian. Stud. Biol. Lab. John Hopkins Univ., vol. 3, 1886, p. 267.

78. --- Note on the presence of Hamoglobin in the Echinoderms. Id., p. 289.

79. JANET. Note sur un Echinocorys carinatus présentant neuf pores génétaux, Bull. Soc. Géol. de France, $3^{\text {me }}$ série, t. 18, 1889, p. 158.

80. JATTA. Sulle forme dhe assume il nucleo vitellino delle Asterie e die alcuni regni, Atti Acad. Napoli, vol. 9, 1882.

81. JENSEN. Recherches sur la Spermatogénèse, Arch. de Biologie, t. 4, 1889.

82. JiCKELL. Vorlaüfige Mittheilungen über den Bau der Echinodermen, Zool. Anz., 1884, Jahrg. 7, p. 8486.

83. --- Über einen der Begattung ähnlichen Vorgang bei Comatula mediterranea, id., 1884, p. 448.

84. --- Vorläufige Mitheilungen über das Nervensystem der Echinoderrmen, 2. Über das Nervensystem der Asteriden, Zool. Anz., 1888, $\mathrm{n}^{0}$ 282, p. 839.

85. ---. Id. 3. Über das Nervensystem der Ophiuren, 1889, n 305, p. 213.

86. JouRdAn. Recherche sur l'histologie des Holothuries, Ann. du Musèe d'His. Nat. de Marseille, t. 1, 1883, mém. $n^{\circ} 6$.

87. KoeHLER. Recherches sur les Echinides des côtes de Provence, Ann. du Musée d'Hist. Nat. de Marseille, t. 1, 1888, mém. № 3.

88. --- Recherches sur l'appareil circulatoire des Ophiures, Ann. Sc. Nat. $7^{\text {me }}$ série, t. 2, 1887, p. 101.

89. KROHN. Beobachtungen aus der Entwicklungsgeschichte der Holothurien und Seeigel. Muller's Archiv, 1851, p.844.

90. --- Ueber die Entwicklung der Seesterne und Holothurien, Muller's Archiv, 1853, p.317.

91. KRUKENBERG. Über de Enzymbildung in den Geweben und Gefüssem der Evertebraten, Unters. a. d. physiol. Institut Heidelberg, bd. 2, 1879, p. 838.

92. --- Vergleichend-physioloische Studien zu Tunis, Mentone und Palermo, Abtheilung 3, Heidelberg, 1880, p. 104.

93. --- Vergleichend-phys. Studien, Abth. 5, Heidelberg, 1881, p. 49.

94. LAMPBERT. Die Seewalzen (in Semper, Reisen im Archipel der Philippinen), bd. 4, Abth. 3, Wiesbaden, 1885.

95. LANGE. Beitrag zur Anatomie und Histologie der Asterien und Ophiuren, Morph. Jahrb, bd. 2, 1876, p. 211.

96. LEYDIG. Anatomische Notizen über Synapta digitata, Muller's Archiv, 1852, p.507.

97. Ludwig. Beiträge zur Anatomie der Crinoideen, Zeits. für wiss. Zool., bd. 28, 1877, p. 255. 
98. --- Beiträge zur Anatomie der Asteriden, Zeits. für wiss. Zool., bd. 30, 1878, p. 197.

99. --- Trichastaer elegans, Z. f. w. Z., bd. 31, 1878, p.59

100. --- Zur Kenntniss der Gattung Brisinga, Zeits. für wiss. Zool., bd. 31, 1878, p. 216.

101. --- Beiträge zur Anatomie der Ophiuren, id., p. 346.

102. --- Ueber die Genitalorgane der Asterina gibbosa, id., p. 395.

103. ---. Die Echinodermen des Milttelmeeres. Mitth. aus der Zool. Stat. zu Neapel, bd. 1, 1879, p. 523.

104. --- Das Mundskelett der Asterien und Ophiuren, Zeits. für wiss. Zool., bd. 32, 1879, p. 672.

105. --- Ueber Astenosoma varium Grube und über ein neus Organ beiden Cidariden, Zeits. für wiss. Zool., bd. 34, 1880, p. 70.

106. --- Ueber den primaren Steinkanal der Crinoideen, etc. Zeits. für wiss. Zool., bd. 34, 1880,

p. 310.

107. --- Neue Beiträge zur Anatomie der Ophiuren, id., p. 333.

108. --- Über eiine lebendiggebärende Synaptide und zwei andere neue Holothurienarten der

brasilianischen Küste, Arch. de Biologie, t.2, 1881, p. 41.

109. --- Zur Entwicklungsgeschichte des Ophiurenskelettes, Zeits für wiss. Zool, bd.36, 1882, p. 181.

110. ---. Entwicklungsgeschichte der Asterina gibbosa, Forbes, Zeits. für wiss. Zool., bd. 37, 1882,

p. 1.

111. --- Über sechstrahlige Holothurien, Zool. Anz., nº 229, 1886, p. 472.

112. --- Ophiopteron elegans. Eine neue, wahrascheinlich schwimmende Ophiuridenform, Zeits. für wiss. Zool, bd.47, 1888, p. 459.

113. --- Berichtgung zu dern von $D^{r}$. Semon beschriebene Falle von "Neubildung der Scheibe in der Mitte eine abgebrochenen Seesternarms”, Zool. Anz. n 315,1889, p. 454.

114. --- Echinodermen (Stachelhaüter), Bronn's Klassen und Ordungen, Leipzig und Heidelberg, 1889-90.

115. --- Bemerkungen über einige ceylonesische Echinodermen, Sitzungsber. der Niederreinischen Gesellschaft zu Bonn, Juin 1890.

116. --- Über die Function der Madreporenplatte und des Steincanals der Echinodermen, Zool. Anz., n 339,1890, p. 377.

I17. Loven. Etudes sur les Echinö̈dées, K. Sv. Vetenskape-Akad. Handlingar, vol. II, n 7 , Stockholm, 1884.

118. --- On Pourtalesia, a genus of Echinoidea, K. Sv. Vetenskaps-Akad. Handl., vol. 19, n 7 , 1883.

119. LutKen. Description de quelques Ophiurides nouveaux ou peu connus avec quelques remarques sur la division spontanée chez les Rayonnés, Ann. Mag. Nat. Hist., vol. 12, 1873, p. 323.

120. Lyman. Ophiuridae and Asrophytidae, Illust. Catal. of the Mus. Comp. Zool. Harvard Coll., Cambridge (Mass.), $\mathrm{n}^{\mathrm{o}} 1,1865$.

121. --- Report ono the Ophiuroidea, The Voyage of the H. M. S. Challenger, vol. 5, 1882.

122. MAC-MunN. On the chromatology of the blood of some Invertebrates, Quat. Journ. Mic. Sc., vol. 28,1885 , p. 469.

123. MARSHALL. On the nervous system of Antedon rosaceus, Quat. Journ. Mic. Sc., vol. 24, 1884, ,p. 507.

124. MARTENS (VON). Über einen sechstheiligen Schlangenstern, Sitzgs. ber. Berrlin Ges. Naturfors. Freunnde, 1879, p. 127. 
125. --- Über das Wiedererzeugungsvermögen der Seesterne, id., 1884, p. 25.

126. --- MeTSCHNIKOFF. Studien über die Entwicklung der Echinodermen und Nemertinen, Mém. de l'Acad. Imp. des Sc. St-Pétersbourg, $7^{\text {me }}$ série, t. 14, 1869.

127. --- Mourson et Schlagdenhauffen. Nouvelles recherches chimiques et physiologiques sur quelques liquidies organaiques, Comptes rendus Ac. Sc. Paris, t. 95, 1882, p. 791.

128. Muller JOH. Ueber die Larven und die Metamorphose der Echinodermen, Abhandl. d. K. Akademie der Wissensch. zu Berlin, 1848-55.

129. --- Anatomische Studien über die Echinodermen. Muller's Archiv, 1850-52.

130. --- Ueber den Bau der Echinodermen, Abhandl. d. K. Akad. d. Wiss. Zu Berlin, 1854.

131. --- Muller Joh. Et Troschel. System der Asteriden, Braunschweig, 1812.

132. MuniER-Chalmas. Observations sur l'appareil apical de quelques Echinides crétacés et tertiaires, Comptes Rendus Ac. Sc. Paris, t. 101, 1885, p. 1074.

133. NeumaYR. Die Stümme des Thierreichs, etc. (Echinodermen), Wien und Prag, 1889.

134. Niemiec. Recherches sur les ventouses dans le règne animal. Rec. Zool. Suisse, t. 2, 1885, p. 1 .

135. Noll. Mein Seewasser Zimmeraquarium. Der Zoolog-Garten, 22 Jahrg., n. 5, 1881, p. 137.

136. PARKER. Poisonous qualities of the Starfish (Solasaster papposus), The Zoologist, vol. 5, $\mathrm{n}^{\mathrm{o}}$ 53, London, 1881, p. 214.

137. PEACH. On the Nigger or Cotton-spinner of the Cornish Fishermen, Ann. Mag. Nat Hist., vol. 15,1845, p. 171.

138. PERRIER. Recherches sur les pédicellaires et les ambulacres des Astéries et des Oursins, Ann. Sc. Nat., $5^{\text {me }}$ série, t. 12-13, 1869-70.

139. --- Recherches sur l'anatomie et la régéneration des bras de la Comatula rosacea, Arch.

Zool. exp. $1^{\text {re }}$ série, t. 4, 1875, p. 605.

140. --- Recherches sur l'appareil circulatoire des Oursins, Arch. Zool. exp., $1^{\text {re }}$ série, t. 4, 1875, p. 605.

141. --- Revision de la collection des Stellérides du Muséum, Arch. Zool. exp., $1^{\text {re }}$ série, t.4 et 5 , 1875-76.

142. --- Sur une Astérie des grandes profondeurs de l'Atlantique, pourvue d'un pédoncule dorsal,

Comptes Rendus Ac. Sc. Paris, t.95, 1882, p. 1379.

143. --- Mémoire sur les Etoiles de mer recueillies dans la mer des Antilles et le golfe de Mexique,

Nouv. Arch. du Musée d'Hist. Nat. de Paris, t. 6, 1884, p. 127.

144. --- Recherches sur l'organisation des Etoiles de mer, Comptes Rendus Ac. Sc. Paris, t. 102, 1886, p. 1146.

145. --- Mémoire sur l'organisation de le développement de la Comatule de la Méditerranée,

Nouv. Arch. du Mus. D’Hist. Nat. de Paris, $2^{\text {me }}$ série, t. 9, $1886 ; 3^{\text {me }}$ série, t. $1,2^{\text {me }}$ fascicule, $1889 ; 3^{\mathrm{me}}$ série, t. $2,1^{\mathrm{er}}$ fasc., 1890.

146. --- Sur la collection d'Etoiles de mer recueilliers par la Commission scientifique du Cap

Horn, Comptes Rendus Ac Sc. Paris, t. 106, 1888, p.768.

147. --- Notions actuellement acquises sur l'organisation des Echinodermes, Bibliothèque de

l'Ecole des Hautes-Etudes, t. 34, 1888.

148. Petit. Ankyroderma Perrieri et hispanicum, Bull. Soc. Philom. Paris, t. 7, 1883, p. 162.

149. --- Remarques sur la Synapta inharens. Bull. Soc. Phil. Paris, t. 8, 1884, p. 50.

150. PREYER. Über die Bewegungen der Seesterne, Mitth. Aus der Zool. Stat. zu Neapel, t. 7, 1886-

7, p. 27 et 191. 
151. Prounou. Recherches sur le Dorocidaris papillata et quelques autres Echinides de la Méditerranée, Arch. Zool. exp., 2érie, t. 5, 1888, ,p. 213.

152. --- Du sens de l'odorat chez les Etoiles de mer, Comptes Rendus Ac. Sci. Paris, t. 110, nº 25, 1890, p. 1343.

153. --- Du röle des pédicellaires gemmiformes des Oursins, Comptes Rendus Ac. Sci. Paris, t. $111, \mathrm{n}^{\mathrm{o}} 1,1890, \mathrm{p} .62$.

154. Quatrefages (DE). Mémoire sur la Synapte de Duvernoy, Ann. des Sc. Nat., $2^{\mathrm{me}}$ série, vol. 17,1842, , p. 19.

155. ROMANES ET EWART. Observations on the locomotor system of Echinodermata, Phil. Trans. London, part 3, 1881, p. 829.

156. RomANES. Observations on the physiology of Echinodermata, Journ. Linn. Soc. London, vol. 1i, 1884, p. 131.

157. Sarasin, P. ET F. Die Augen und das Integument der Diadematiden, Ergebnisse Naturw.

Forschungen auf Ceylan in den Jahren 1884-6, bd. 1, heft 1, Wiesbaden, 1887.

158. --- Knospenbildung bei Linckia multifora Lamarck, id., bd. 1, heft 2, 1888.

159. --- Ueber die Anatomie der Echinothuriden und die Phylogenie der Echinodermen, id. bd. 1, heft 3, 1888.

160. SCHLUMBERGER. Seconde note sur les Holothuridées fossiles du calcaire grossier, Bulletin de la Soc. Géol. de France, $3^{\text {me }}$ série, t.18, 1890, p. 191.

161. SELENKA. Beiträge zur Anatomie und Systematik der Holothurien, Zeits. für wiss. Zool., bd. 27, 1876, p. 155.

162. --- Zur Entwicklung der Holothurien, Zeits. für wiss. Zool., bd. 27, 1876, p. 155.

163. SEMON. Das Nervensystem der Holothurien, Jen. Zeits. für Naturw., bd. 16, 1883, p. 578.

164. --- Beiträge zur Naturgeschichte der Synaptiden des Mittelmeeres, Mith. Zool. Stat. zu Neapel, bd. 7, 1887, p. 272 et 401.

165. --- Die Entwicklung der Synapta digitata und ihre Bedeutung für die Phylogenie der Echinodermen, Jen. Zeits. für Naturw., bd. 22, 1888, p. 175.

166. --- Ein Fall von Neubildung der Scheibe in der Mitte eines abgebrochenen Seesternarmes, Jen Zeits. für Naturw., bd. 23, 1889, p. 585.

167. --- Die Homologien innerhalb des Echinodermenstammes, Morph. Jahrb. Bd. 15, heft 2, 1889, p. 28.

168. SEMPER. Reisen im Archipel der Philippinen ( $2^{\text {me }}$ partie, bd. 1), Holothurien. Wiesbaden, 1868.

169. Simroth. Anatomie und Schizogonie der Ophiactis virens, Zeits. für wiss. Zool., bd. 27 et 28, 1876 et 77, p. 417 et 419.

170. SLADEN. On the structure of Astrophiura, a new and aberrant genus of Echinodermata, Ann. Mag. Nat. Hist., vol. 4, 1879, p. 401.

171. --- On a remarkable form of Pedicellaria, etc., Ann. Mag. Nat. Hist., vol. 6, 1880, p. 101. 172. --- On the homologies of the primary larval plates in the test of brachiate Echinoderms, Quat. Journ. Mic. Sc., vol. 24, 1884, p. 24.

173. --- Report on the Asteroidea. The Voyage of H. M. S. Challenger, vol. 30, 1889.

174. STEWART. On certain organs of the Cidaria, Trans. Linn. Soc. London, $2^{\text {me }}$ série, vol. 1, p. $569,1879$.

175. --- Note on an abnormal Amblypneustes griseus, Journ. Linn. Soc. London, Zool., vol. 15, 1880, p. 130. 
176. STÜRTZ. Beitrag zur Kenntniss palaeozoischer Seesterne, Paleontographica, bd. 32, 1886, p. 75.

177. --- Neuer Beitrag zur Kenntniss palaeozoischer Seesterne,, Paleontographica, bd. 36, 1890, p. 203.

178. TeusCHER. Beitäge zur Anatomie der Echinodermen, Jen. Zeits. für Naturw., bd. 10, 18876, p.243 et p. 498.

179. THEEL. Mémoire sur l'Elpidia, Kongl. Sv. Vet. Akad. Handlingar, Stockholm, bd. 14, 1877. 180. --- Report on the Holothurioidea, The Voyage of H. M. S. Challenger, vol. 4, 1882.

181. ViguiER. Anatomie compare du squelette des Stellérides, Arch. Zool. exp., $1^{\text {re }}$ série, t. 7, 1878, p. 33.

182. Vogt et Yung. Traité d'Anatomie comparée pratique, t. $1^{\mathrm{er}}$, 1888, Paris, Reinwald, p. 514.

183. WALTER. Untersuchungen über den Bau der Crinoiden, etc. Paleontographica, bd. 32, 1886, p. 155.

184. Wachsmuth et Springer. Revision of the Palaeocrinoidea, part 3, Proc. Acad. N. Sc. Philadelphia, 1885-86.

185. WiLliams. On a Crinoid with movable spines (Arthoacantha Ithacencisi), Proc. Amer. Phil. Soc., vol. 21, 1884, p. 81.

186. ZitTEL. Traité de Paléontologie (traduction Barroisi), t. 1, 1888, Paris (Doin).

\section{ORIENTATION}

Before beginning any anatomical study, it is indispensable to agree on the position to give the animals studied in order to be able to relate all the descriptions.

As in my preceding works (asteroids, ophiuroids) and with H. Carpenter and Perrier (crinoids), Prouho (urchins), Hérouard (holothuroids), I place echinoderms, whatever it be, in a vertical position, the mouth or oral pole above, the opposite pole or aboral below. The oral face (often called ventral) will be above. The aboral or dorsal face will be below. In this manner, the synaptids, the holothuroids and the crinoids rest in the normal orientation. The urchins, ophiuroids and asteroids will be inverted to the ordinary orientation. The advantages of adopting such a equal convention are so evident that it does not seem useful to discuss the conventions adopted by Ludwig, Hamann, Carl Vogt and Yung.

NOMENCLATURE OF THE RADII. - Because the echinoderms are divided into five radii and five interradii, it is convenient to adopt from the beginning a nomenclature that permits designating these diverse regions. For that, it is necessary to have a fixed point of departure. This will be for us the first hydropore of the young. All authors accept, in fact, especially since Ludwig, that the interradius where this pore opens is always the same in the various echinoderms. This hypothesis agrees perfectly with all the organogenic results. Suppose now the echinoderm is placed as we just defined it, i.e. resting on the apex, and projected onto a horizontal plane, a circle or a pentagon results with the mouth at the center from which leave the five radial ambulacra. In one of the interradial spaces opens the first hydropore. We shall extend to all echinoderms the nomenclature so simple and so logical proposed by $\mathrm{H}$. Carpenter for crinoids. The radius opposite the hydropore will be radius $\mathrm{A}$. The other radii, in a clockwise direction, will be radii $\mathrm{B}, \mathrm{C}, \mathrm{D}, \mathrm{E}$. The interradii are designated by the letters of the radii that contain them. Thus the interradius of the pore will be 
$\mathrm{CD}$. The following will be $\mathrm{DE}, \mathrm{EA}, \mathrm{AB}, \mathrm{BC}$. This nomenclature seems to me much preferable to all those proposed by others, Lovén for the urchins and Ludwig for the holothuroids (114).

PLANE OF BILATERAL SYMMETRY. - The plane of bilateral symmetry is very difficult to define. As we know, all the echinoderms descend from a larva with bilateral symmetry. They only secondarily take on a radial appearance. However they keep unpaired organs or can return to symmetry in relation to a plane (holothuroids, spatangoids). First important remark: the plane of bilateral symmetry secondarily acquired or determined by the existence of unpaired organs has no relation at all with the plane of symmetry of the larva and is completely superficial, at least in the present state of our knowledge, using the latter to determine the former (Bury, Ludwig). Second remark: bilateralness of echinoderms, when it is very clear, is entirely a secondary mechanical adaptation and the plane of symmetry is not at all the same in the different types. When bilateralness is not evident, this is little more than a point of view whose study can have interest but that is not necessary to consider as a morphological fact. In the same type of urchin, asteroid or ophiuroid, there are in fact several planes of symmetry of which one is more or less predominant according to the species (see pl.XXXI).

$1{ }^{\circ}$ Synaptids and holothuroids. - In adult synaptids the bilateral plane is obvious. It passes by the stone canal and the mesentery (called dorsal) where the gonads are found. Although synaptids are transformed directly from the larva, it is easy to see that this plane does not coincide at all with that of the latter. In fact, the water pore is to the left of the plane of symmetry in the larva while it is found in it in the adult.

Holothuroids have the same plane of symmetry. It is very pronounced in Stichopus, Mulleria, Colochirus, Psolus and elasipodes according to locomotory differentiation of the face next to the substratum, containing the radii $\mathrm{E}, \mathrm{A}$ and $\mathrm{B}$, forming the trivium. The two others, $\mathrm{C}$ and $\mathrm{D}$, make up the bivium. We shall call the plane of symmetry of synaptids and holothuroids the holothuroid plane (interradius $\mathrm{CD}$, radius $\mathrm{A}$ ).

$2^{\circ}$ Crinoids. - In crinoids, the holothuroid plane is still the plane of symmetry. In Antedon, for example, it is clear that this is determined by the mouth, the anus and the base of the calyx. Bury demonstrated (16) with arguments that seem convincing to me that, contrary to the opinion of Luldwig, the anus opens into the same interradius $C D$ as the hydropore (Ludwig thought the anus opens into the adjacent interradius BC). If, instead of multiplying pores in the calyx, Antedon remains in this state, the bilateral plane passes through the mouth, the apex, the anus and the hydropore, i.e. that it would be identical to that which is so well defined in holothuroids. This identity of position is even one of the reasons I prefer Bury's opinion to that of Ludwig.

In present crinoids, the bilateral plane is not of great importance. However when the mouth leaves the middle of the oral face to become eccentric, as in Actinometra, it still keeps the holothuroid plane determined by the apical pole, the anus and the center of the oral face.

$3^{\circ}$ Echinoids. - It is convenient to begin with the form that has best kept the primitive characters, i.e., the regulars. This is a rule too often forgotten in morphology.

The regular urchins show the interesting fact of having several planes of symmetry, having different meanings.

$1^{\circ}$ Holothuroid plane. - In the young urchin, while the anus has not yet opened, the sole plane of symmetry is that which goes through the mouth, the apical pole and the hydropore, i.e., the holothuroid plane. It is moreover of little importance in urchins as most organs are arranged outside it. 
$2^{\circ}$ Lovén's plane. - This is more important in the class that concerns us. It was proposed by Desor and Cotteau, but it was Lovén (117) who has mainly defined it well and we shall designate it by the name of the Swiss scholar. It passes through interradius $\mathrm{AB}$ and radius $\mathrm{D}$, adjoining the madreporite, and makes an angle of $36^{\circ}$ with the holothuroid plane. In some urchins with an eccentric anus, this is found in Lovén's plane, close by interradius AB (Acrosalenia, Pseudosalinia, Peltastes, Goniophorus and various cretaceous diademids, Pseudodiadema, Cypohhosoma, Echinocyphus). The digestive tube is most often symmetrical in relation to this plane, or to say it better, the latter is crossed only once by the two intestinal loops (this is not absolutely exact). Heterocentrotus Brandt, Colobocentrotus Bdt, Parasalenia Ag. have an elliptical test (like Echinometra) with the short axis in the two first genera and the long axis for the third coincident with Lovén's plane. The latter is thus the plane of bilateral symmetry like the echinoid plane for Echinometra Van Brunti and lucunter.

It has been little noted until now that elongation of Echinometra does not occur in the same plane for all species and that even it is not constant in all individuals of the same species. I have in hand a specimen of Echinometra subangularis Desm., that Cotteau has kindly let me determine, whose long axis coincides nearly precisely with Lovén's plane. On the other hand, in the photographs that Agassiz gave of Echinometra viridis and subangularis, it is very clear the long axis of the ellipse passes through radius $\mathrm{E}$ and the middle of interradius $\mathrm{BC}$, i.e., it does not coincide at all with the three planes we have examined until now. The same thing should be studied in numerous specimens.

In irregular urchins (clypeasteroids, spatangoids), bilateral symmetry of the test becomes very apparent. Lovén's plane is so predominant that the holothuroid and echinoid planes are not recognizable. The anus, which is between the echinoid plane and Lovén's plane in the regular urchins, is fixed definitively in the later. All the organs tend to become symmetrical in relation to this plane, as the gonads, two (Shizaster) or four (Spatangus, Echinocyamus etc.) in number, loops of the digestive tube and all the structures of the test (ambulacra, fascioles, spines etc.). Finally the stone canal and axial gland leave the holothuroid plane and approach Lovén's plane.

The three planes (holothuroid, echinoid, Lovén's), primitively very distinct in regular urchins, tend to be combined into a single one (Lovén's) in the irregular urchins that have acquired a true bilateral symmetry.

When one places through the apex a vertical perpendicular plane perpendicular to Lovén's plane, the radii are separated into two groups. The three radii C, D, E form the trivium; A and B, the bivium. The bivium and trivium, as Ludwig (106) very clearly showed, are not at all identical to the parts of the same name in holothuroids that are comprised of radii E, A and B and radii C and D.

$4^{\circ}$ Asteroids and ophiuroids. - In normal ophiuroids (with five arms), adult Astropectinida and all young asteroids whose anus is not yet open, the only plane of symmetry seen is the holothuroid plane passing through the apex, the mouth and the hydropore. As the organs are perfectly symmetrical, this plane has little importance in these animals.

In adult asteroids, the anus is eccentric, in interradius BC (Ludwig). Lovén (117) mistakenly thought the anus would be in radius B as in echinoids. However several of his figures are correct and formally contradict his text. We shall call the plane passing through the apex (where the brachial muscles meet), the mouth and the anus (interradius BC, radius E) the asteroid plane. It makes a $108^{\circ}$ angle with the holothuroid plane. It has moreover no more importance than the latter. Ludwig, in several of his works, has however used it to orient asteroids.I 
$\S$ The preceding pages show no morphological plane of symmetry truly exists in echinoderms. The only one that could have a claim is the holothuroid plane because it is determined by the first unpaired organ formed in the young (hydropore) $\left({ }^{4}\right.$ ). But by various mechanical influences various planes of secondary symmetry are produced in echinoderms that are more or less important (echinoid plane, Lovén's plane, asteroid plane), and that have no relation with each other. The study of anomalies in number completely supports this point of view. In fact, as Haacke (65) has already remarked for urchins, when there is a radius more or less (6 or 4), the anomaly produced by it is of no importance for the echinoderm and always remains unpaired. The echinoderm appears to us thus from its origin (and not least in its exterior form and its body wall) strongly radial and secondarily bilateral.

It is thus entirely artificial and useless to determine a right and a left. In the course of this work, I will simply designate the radius and interradius by their respective letters without preoccupying myself with their position in relation to various axial planes. I shall not attend to the conventions adopted by different authors, conventions often contradictory that make impossible to separate the simplest descriptions.

\section{FIRST PART}

\section{INTEGUMENT}

A section of the integument of any echinoderm nearly always shows an external epithelium, a thick middle layer, connective, muscular or calcareous, and an internal epithelium or peritoneal covering. The first of these three layers is not always present and seems to have disappeared in some cases (ophiuroids, Antedon, Cucumaria etc.).

Before examining them in detail, it is convenient to follow their origins. The internal epithelium represents the wall of the enterocoelic sacs (vaso-peritoneal vesicles) derived from the archenteron, whose wall is applied on one side to the digestive tube and the other to the integument. This is the mesoderm, following the terminology of Hertwig, which furnishes simply a thin layer of peritoneal cells and a part of the nervous system (enterocoelic nervous system). The middle layer, in the young (at the moment when they separate from the larva), is represented by an accumulation of cells derived from preexisting layers that become free in the segmentation cavity, divide considerably and end by filling it completely. These cells represent the true middle layer (Hertwig's mesenchyme), very thick in echinoderms, at least of those forming all the connective and muscular tissues $\left(^{5}\right.$ ). These mesodermal cells, which are very abundant in young individuals

\footnotetext{
${ }^{4}$ Various authors (Agassiz, Müller) have tried to use the madrepore to orient echinoderms. Agassiz applied it especially to embryological observations and de Lacaze-Duthiers formerly proposed it in his courses at the Museum. 5 In the description that follows, I have not taken into consideration, like Semon, Hamann etc., of the distinction proposed by Hertwig between the mesenchyme and the mesoblast. It is not useful to maintain these distinctions in echinoderms, at least from the histological point of view. In fact, the mesenchyme in some schizocoelic cavities, often takes the epithelial form characteristic of the mesoblast. I shall call the enterocoel mesoderm the covering of the coelom and mesoderm all the rest of the middle layer.
} 
(pl. XXV, fig. 26), have a large nucleus. They often have nucleoli and always an indistinct protoplasm. In adults some undifferentiated or connective tissue cells are always found. They are sometimes rounded, sometimes more or less star-shaped.

MUSCLE TISSUE. --- Muscle fibers, formed by differentiation of a single mesoderm cell, have the same characters in all groups. It is completely smooth, clearly terminated at its ends. It has a lateral nucleus surrounded by some cellular granules. They are found in the figures of Jourdan (86), Hamann $(67,68,69)$ and in my memoir on asteroids (28) etc. All stains give it special colors that do not permit mistake. E.g., in triple staining with methyl green, orange and fuchsine (see page 317 ), it takes a clear orange color while the connective tissue becomes pink. It is always rectilinear or slightly waved while connective fibrils are folded with all the movements of the organs where they are found.

Striated muscle fibers are known in a certain number of echinoids. Geddes and Beddard (55) have reported them with a strong uncertainty. Hamann studied them with more care and I have completely confirmed his results (69). The adductor muscles of buccal and tridactyl pedicellariae (Centrostephanus longispinus, Dorocidaris papillata, Arbacia pustulosa, Strongylocentrotus lividus, Sphachinus granularis, Echinus acutus and microtuberculatus according to Hamann; $E$. Melo according to Beddard) as well as the muscles of the spines of the periproct of Centrostephanus longispinus (with the exception of other spines, Hamann) are entirely formed of them. They are very short fibers, nucleated as usual, having thin dark close striations. They are very close together and very clear. They disappear towards the ends (figures in Hamann, 69). The striation is always very difficult to recognize. It is very apparent in specimens in alcohol. In agreement with Hamann, adductor muscles that quickly close the valves of pedicellariae are the remarkable exception.

Only in crinoids does muscle tissue show truly inexplicable characters. Here are the facts: the calcareous pieces of the arms and pinnules are united from the side of the ambulacral groove by a pair of muscles perfectly characteristic in all ways like muscles of other echinoderms (refringent muscles of Perrier) and from the opposite side by a unique mass of special fibrous tissue (Hamann's spindligen Muskelfasern, Perrier's hyaline muscles) completely different in aspect. Most authors except Jickeli, Hamann and Perrier have considered them ligaments. In the cirri and the stalk, there are no refringent muscles at all. The pieces are united simply by packets of fibrous tissue. The only reasons this fibrous tissue could be considered muscular are physiological ones: the cirri of Antedon are certainly susceptible of movement, very slowly to be sure; the stalk of Pentacrinus can effect certain movements (Förste has even described a fossil stalk of an undetermined crinoid that was twisted into a spiral, 52). The arms can move water from top to bottom and from bottom to top as if these antagonistic bundles were both muscular. But if from the physiological point of view, as Jickeli has well proven and as Perrier has noted correctly (145), it is necessary to admit that this tissue acts like a muscular tissue, it is necessary to recognize that there are enormous histological differences. It is formed of very delicate nucleated fibrils (figures in Hamann, 71) mixed at their two ends with the organic network of calcareous pieces that unite them instead of being clearly separated as are the muscle fibers. In the contracted state, these parallel fibrils do not stay rigid. They bend and show a strong undulation in their middle as Perrier (145) observed very well. Their contraction, if it really exists, is thus something completely different from that which characterizes muscles. Picrocarmine colors it bright pink. It does not absorb eosin well. Finally, in triple staining, they absorb fuchsine and are colored pink while true muscles are orange (Antedon, Pentracrinus). At their ends, these fibrous packets are mixed, as I 
have said, with the calcareous network, covered at this point by cellular masses that Perrier considered like small miniscule ganglia in connection with the nerve centers. For my part, I have not been able to reach an opinion on their nature and cannot confirm in Antedon even that they exist. They do not exist in Pentacrinius Wyville-Thomsoni. They are not at the level of true muscles.

The muscular nature of this singular tissue still does not appear to me definitively demonstrated. It would be indispensable to undertake their study in vivo with very precise physiological experiments, because it seems to me completely extraordinary that two contractile tissues as different in their histological makeup as in their histochemical properties could coexist in the same animal. Perrier considered this hyaline fibrous tissue as truly muscular and by a reaction that I do not believe well founded he appeared very disposed to interpret as ligaments the true typical refringent muscles. Hamann calls the first "spindligen Muskelfassern" but he has no more convinced than I of their nature because he says expressly, "Eine strenge Grenze zwischen elasticher Faser und kontkraktiler Spindelzelle kanne ich nicht auffinden (71, p. 353)." The fact is that it is impossible to draw a deep divide between these fibrils and articulating connective tissue that has exactly the same color. We find in other echinoderms fibrillar tissue that is very similar to that of crinoids, but never in masses as great and it has always been considered, with good reason it seems, according to its location, as ligament. It would be desirable to decide definitively about the so-called hyaline muscle of crinoids.

NON-CALCIFIED CONNECTIVE TISSUES --- In spite of the great diversity in appearance, it is not very difficult to establish a classification of non-calcified connective tissue:

$1^{\circ}$ Rounded or star shaped connective cells that never have a very great development.

$2^{\circ}$ Fundamental substance (Grundsubstanz, Intercellularsubstanz of Semper and Hamann). This is a non-cellular substance secreted from mesoderm cells that takes a variable consistency depending on the organ. It forms all the middle layer in asteroids and notably Calcita $(20 \mathrm{~mm}$ thick in Culcita coriacea) and acquires a consistency comparable to that of rubber. Sometimes, as in the innermost wall of holothuroids (lacunar layer of Jourdan, Hamann and Hérouard), it remains in a soft gelatinous state in which are found a large number of migrating cells. Very often, instead of remaining amorphous, it disintegrates into interconnected, more or less elongated fibrils whose arrangement can vary infinitely. Nearly all the integument, as well as articulations, elastic ligaments and organ walls are formed of this fundamental substance, either amorphous or fibrous, containing a more or less large number of mesoderm cells.

$3^{\circ}$ Connective tissue fibrils of variable form and length have a nucleus (see the specialized monographs of Jourdan, Hamann, and Cuénot for details). It is sometimes very difficult to establish a distinct limit between these fibrils and the fundamental substance with a fibrous texture. They are especially clear in the skin of holothuroids and synaptids.

CALCAREOUS TISSUES. --- The histology of calcareous tissues, which plays such a great role in the makeup of echinoderms, is now well known. The differences mainly concern their mode of formation. These tissues take the form either of a more or less complex network (calcareous matrix) or of very varied spicules. There are only rare exceptions to cite such as the otoliths of elasipods and the biscuit-shaped corpuscles of synaptids. As for the teeth of urchins, they are formed by the accumulation of a quantity of intercalated spicules between connective tissiue membranes (see the complete work of Giesbrecht (60).

The works of Leydig, Valentin, Hoffmann etc. have shown that the calcareous tissue is formed of two tangled networks that are joined together. One is mineral and the other organic. After decalcification, only the organic network remains, pierced by holes corresponding to the 
calcareous mesh removed by the acid (pl. XXIV, fig. 3). In synaptids and holothuroids, the organic network is nearly absent in the plates of small size. In contrast, it is very clear in the pieces of the calcareous ring. In sections of the non-decalcified sections of the holothuroid skin, each plate is fixed solidly in the surrounding tissue by small fibrous bundles that pass into the holes. They cross in all directions, accompanied naturally by the more or less numerous mesoderm cells. In pieces of some size, the organic network is made up nearly in the same manner in all groups: a loose fundamental substance with scattered mesoderm cells and sometimes granules of black pigment (Arbacia, Spatangus, ophiuroids). The fundamental substance does not have channels strictly speaking, although fluid can be circulated within it. In fact, colored gelatin injected against the plate results in very deep penetration between the fibrils of the fundamental substance. It is in Dorocidaris papillata, as Prouho (151) has quite exactly described and still more in Spatangus purpureus, that the channeled appearance is most clear. The circulating coelomocytes that are very numerous in urchins, holothuroids and Ophiactis virens, likewise move in the fundamental substance (pl. XXIV, fig. 3). Finally, in addition to the pigmented material that is frequently found in the skin, there are sometimes excretory products accumulated as in other tissues, particularly in urchins (especially Spatangus purpureus), some ophiuroids, Antedon rosacea etc.

The mesoderm cells often form small clustered masses of the network. Occasionally the cells are joined and form a more or less extended sort of syncytium, as I have shown from examples in asteroids and Perrier in Antedon.

The organic network evidently serves for the nutrition of the calcareous network, although that must be very insignificant. It is especially the way by which nutritive fluid reaches superficial parts (especially in urchins with a continuous calcareous test). Finally, its numerous cells represent an important reserve for the entire organism.

Spicules. --- Spicules are surrounded by a very fine structureless membrane that is molded to its contours (pl. XXIV, fig. 6). It is quite visible after slow decalcification (synaptid anchors, urchin spicules etc.). Often some believe they have seen a clearer zone in the interior, a canal according to some authors. I believe rather that this is an illusion produced by a difference in refringence of the first layers. Van Ankum (4) however described a fine central canal in spicules that enclosed a protoplasmic filament (spiculine). Semper, Semon, Théel, Herapath, Ludwig etc., generally agree calcite covers an organic axis. Because I have not being able to find it by staining, even after decalcification, I think its demonstration is still not sufficient.

Calcite network. --- The calcareous network has been studied from the optical point of view mainly by Ebner (47, p. 137). In polarized light, echinoderm calcareous tissues (spicules or plates) seem to have a crystalline structure exactly like sponge spicules. Each skeletal part behaves optically like a single crystal. I can confirm entirely these results for all echinoderm calcareous bodies with the exception of otoliths, which have no action at all on polarized light.

Development. --- When a calcareous plate is formed either in the embryo and the young or in the adult, first is an accumulation of mesoderm cells that multiply abundantly and form an entirely cellular mass. Prouho has clearly reported this in the young spines and pedicellariae of Dorocidaris (151). Deposition of calcite begins then. Semon (164) showed that a large number of cells enclose at this moment small tetrahedrons of calcium carbonate, which is material all ready to be utilized. According to Semon, all calcareous tissue begins in this tetrahedral form. But there are still several cases to clarify. Consider first a reticulated plate.

$1^{\circ}$ The first appearance takes place in the form of a trifid spine with $120^{\circ}$ angles (according to Semon, the three points are oriented according to three of the axes of the primordial tetrahedron). It is very clearly extracellular and covered on all sides by mesoderm cells that have contributed to 
its formation. This is thus a fundamental distinction from many other spicule formations (sponges) that, it seems, result from mineralization of a cell. In echinoderms, calcite is deposited between the cells in the fundamental substances (good figure in Semon, 164). Many authors have stated the appearance of the primordial trifid spicules (Schultze for Amphiura squamata, Ludwig for ophiuroids, Simon for different classes, Fewkes for Echinarachnius parma etc.). The trifid spine grows rapidly by new calcareous layers like a crystal in a saline solution.

It is bifurcated at its two ends, always at an angle of $120^{\circ}$, ini a way to make a $>-<$ form that has been repored nearly everywhere (Théel for young plates of elasipods, Semon in the anchor plates of synaptids, Ludwig in aspidochirotes and dendrochirotes; we see it more or less clearly in the figures of embryos of Ludwig, Fewkes, Bury etc.)

Development continues in the same way. The ends are bifiurcated always at $120^{\circ}$, joining in such a way to form a hexagonal network containing large holes in which are lodged calcigenic mesoderm cells (bl. XXIV, fig. 1). The network continues sometimes to develop regularly, as for example in the plates of the skin of holothuroids and synaptids. But most often it becomes irregular, the mesh becomes very unequal, the angles rounded and are thus unrecognizable.

$2^{\circ}$ As for the valves of pedicellariae, spines (asteroids, ophiuroids, echinoids) wheels (holothuroids, larval Auricularia), the first form that appears is a spicule with three of four points (Semon, Ludwig). Then it generally forms a sort of wheel with six spokes on which arise stalks perpendicular to the plane of the wheel. But the stalks and the spokes instead of being regularly bifurcated multiply in diverse directions. They are covered with bumps. They build between the mesoderm cells a more or less complex structure that takes little by little the definitive form.

$3^{\circ}$ Development takes place following a third type for the non-reticulated bodies like the anchors of synaptids, the arc-shaped spicules characteristic of Stichopus among the holothuroids and the echinids and echinometrids in urchins (J. Bell) etc. The first appearance with the form of a short baton elongates little by little, is curved and by a series of transformations reaches its definitive stage without having any stage with regular geometry. The developing spicules are surrounded by numerous mesoderm cells, as all embryologists have illustrated for the rods of Pluteus. When they reach their definitive size, the cells emigrate and the spicule remains isolated in the layer where it was formed without having any organic stroma.

Semon (164) and Ludwig (114) give good figures showing well these diverse processes of developoment.

$\S$ All the phases calcareous cells go through are fixed in different echinoderms. Thus large trifid spicules (with some supplementary ornaments) are found in many organs of cidarids, notably Cidaris tribulö̈des (Ludwig, 105), Dorocidaris papillata etc. The plate in $>-<$ is well developed as well as the network with four equal links at the base of the tube feet of Holothuria catanensis Grube (according to Hérouard) and several other species (114, see page 50). The large wheels with spokes that are the first phase of the spines of asteroids, ophiuroids and echinoids are found isolated in the skin of numerous species of Chiridota (illustrated in Semper, Semon, Ludwig etc.) In the skin of Holothuria aspera J. Bell, the spicules show a lower stage; they have the form of a star with six branches.

In summary, I think like Semon that the deposition of calcite in echinoderms is a kind of crystallization operating in the meshes of an organic conjunctive tissue network. The agents of calcite secretion are mesoderm cells that fill at first sight the organic network. The point to remember is that the development of plates and spicules is clearly extracellular. Hérouard (1890) has given a theory quite different for holothuroids. For him, a calcareous areolar corpuscle is formed from a certain number of hexagonal cells. The nuclei of these occupy the areoles and the 
mineral material is deposited along the walls of contact. Ludwig has already criticized the views of Hérouard that I also cannot accept. When decalcification is carefully done, cells are not found at the place of calcareous corpuscles. That is completely certain. The nuclei often seen in the spaces are nothing other than those of migrating coelomocytes or connective tissue cells. Finally, the study of development excludes all idea of intracellular development.

Ototliths, biscuit-shaped corpuscles. --- The otoliths enclosed in the numerous otocytes of elasipods (Elpidids) are formed of concentrate layers (calcium phosphate according to Théel) of glassy appearance. Each otolith is in reality a cell enclosed by a fine membrane whose nucleus is compressed into one of the ends (Elpidia glacialis, pl. XXVIII, fig. 50).

Finally, in synaptids, molpadids and some aspidochirotes (114, p. 49) rounded or kidneyshaped calcareous bodies (biscuitförmigen Kalkkörper) are found. They have on one side a more or less deep notch containing a nucleus (pl. XXIV, fig. 2). The nucleus is rarely surrounded by the calcareous deposit. When it is at the center of the corpuscle, a small groove leaves from the central cavity to open at the periphery. The calcareous deposit appears to be made up of concentric layers. Finally, the corpuscle is bounded by a very fine membrane. The biscuit-shaped corpuscle appears in the interior of a small mesoderm cell in the form of a short rod or ovoid globule. I have not seen a primordial tetrahedron. It then grows little by little in surrounding the nucleus that is only rarely enclosed by the mineral deposit. Otoliths are the only echinoderm spicules whose formation is intracellular. This is the reason I have separated them from ordinary spicules whose development is clearly extracellular.

\section{BODY WALL}

The histology of the different tissues known, we can now examine rapidly their distribution in the body wall of different echinoderms.

Asteroids. - In asteroids, from outside in, are found the ciliated ectodermis with numerous glandular cells (mucous and muriform), a thick layer of very dense fundamental substance containing calcareous nodules towards its surface, then a thin muscular zone with fibers that are sometimes radial and sometimes circular and finally the ciliated peritoneal epithelium. The body wall, while being very resistant thanks to the external calcareous masses, has a certain flexibilitiy. This is very great in case of rupture of the arm or disc, the wound being immediately closed by contraction of the peritoneal muscles.

Ophiuroids. - In ophiuroids all is sacrificed for rigidity of the body wall. There is no distinct external epithelium (pl. XXIV, fig. 8). There are calcareous plates on the outside of the body that cover the internal peritoneal epithelium. In order to know what happened to the ectoderm, it is necessary to study the origin of these layers. To do this I have studied the embryos of Amphiura squamata that are found in large numbers as is known in the bursae of adults. The ectoderm is still visible immediately after the pluteus develops. It is formed of large cells with a thin cuticle and greatly resembles neighboring mesoderm cells (pl. XXV, fig. 26). As Amphiiura grows, the mesoderm cells invade the ectoderm and it is soon completely impossible to establish the separation between the two layers. When calcification begins, it is produced by thickening of the entire test thickness. The peripheral calcigenic tracts usually have a very great number of nuclei filling an elongated cellular body. These are evidently the little differentiated ectoderm cells. Thus the ectoderm has not disappeared by wearing away as one might think. They are simply mixed 
with the underlying mesoderm and probably interact with it in secretion of calcite. The ectoderm clearly exists only in some points, on the ambulacra, in the intervals of tooth plates and finally on the oral surface for the formation of the nervous system.

In euryales (Astrophyton clavatum), the ectoderm remains perfectly visible on the disc and part of the arms, but the fine branches of the latter absolutely lack it like the test of ophiuroids.

Echinoids. - In urchins, although the test is entirely rigid (with rare exceptions), it is well protected by numerous spines and appendages of the surface. Also the ciliated external epithelium covering the calcareous plates is well developed. A ciliated internal epithelium is always found on the internal surface of the coelom.

Crinoids. - In Antedon, Pentacrinus etc., the nonciliated ectoderm is quite visible on the oral surface of the disc and arms (it is ciliated in the ambulacral grooves), but it most often mixed with the mesoderm on the rest of the animal. On certain pinnules, the filiform cells that make it up, lodged in the intervals of the calcareous network, are still quite recognizable. Sometimes they can even form a continuous layer, but more usually they are mixed with the ectoderm and underlying mesoderm are mixed as in ophiuroids.

Before attaching, the larvae of Antedon rosacea has a very clear ectoderm, formed of tall cells. A little after attaching (cystid phase of Perrier and Bury), by a kind of histolysis, it becomes impossible to make the distinction between the mesoderm and the ectoderm on the stalk and the body wall. In sections, the body seems covered by mesoderm, the ectoderm no longer existing as a regular layer (Barrois, Bury, 8, 16; see also the figures of Perrier, 145). Later, after the vestibule opens, the ectoderm is very clear on the oral surface of the disc, the tube feet and the ambulcral groove. But the lower part of the arms, the disc and pinnules remains almost completely lack a distinct epithelium. The process of the mixing of the two layers is very similar to that we have described for ophiuroids.

Holothuroids. - The characters of the body wall differ according to species, especially the ectoderm. In Holothuria (H. tubulosa, catanensis), the strongly pigmented external epithelium is well defined but lacks cilia. It is covered by a thick strong cuticle (see a good figure in Jourdan, pl. 1, fig. 2). The middle layer comes next. It is a dense fundamental tissue with connective fibrils containing calcareous plates that are especially abundant on the outer side. On the internal side, the middle zone has a remarkable differentiation. It is formed of very loose gelatinous fundamental substance with migratory amoebocytes. There are also many intercalated excretory products. This zone is very characteristic of holothuroids and has been thoroughly studied by Hérouard 13). He and Jourdan called it the lucunar layer (Plasmawanderzellenschicht of Hamann). It is followed by circular muscles and the peritoneal epithelium.

In Cucumaria, the ectoderm has a very different aspect (pl. XXIV, fig. 4). The cells are gathered together in small separated masses embedded in the surrounding fibrous tissue. Some packets of fibrils pass between them and extend below, under the cuticle, so that the masses are entirely buried in the fibrous tissue. Those under the cuticle contain a very large number of migratory cells. Below each cellular mass is found a kind of chamber filled with gelatinous fundamental substance. It is stained clear blue by methylene blue. It contains a very large number of migratory ameobocytes. The ectoderm cells have a basal nucleus. Their cellular body is reduced to a very fine filament that ends at the cuticle, crossing perpendicularly the sub-cuticular fibrous layer. Figure 4 of plate XXIV will make clear this arrangement that is very difficult to describe. Hérouard (73) has clearly seen the chambers but does not seem to recognize their meaning and their relative arrangement. 
Over the entire body surface ectoderm is always mixed with connective tissue. The masses come together and nearly make a continuous epithelium on the buccal tentacles and tube feet. I have found the same mixture on the ambulacra of Holothuria Sanctorii. These are covered with turriform calcareous corpuscles that underlie the cuticle. Under them is a continuous epithelium formed of cells with a basal nucleus and an extension to the cuticle. But between the latter and the nucleus is a base of connective tissue fibrils that is connected from place to place (especially at the level of the calcareous corpuscles) to the conjunctive layer of the tube feet. This singular mixture of the ectoderm and mesoderm probably is related to the greater toughness of the body wall. It will probably be found in many other holothuroids. I do not believe it has been reported previously.

In Elpidia glacialis (Elasipode), the body wall is remarkably rigid, thanks to the entangled long calcareous spicules (Théel, 179) whose points project to the exterior. The ectoderm has completely disappeared except on the buccal and tentacular regions as Théel noted. A thin connective tissumuscular layer comes after the spicule layer and, as always, the peritoneal epithelium. The body wall of Elpidia does not have another structure to support the entangled spicules. Even very slow decalcification produces considerable retraction of the body wall that is shriveled in a way to make sectioning impossible.

Synaptids. --- In symaptids, the perfectly defined ectoderm, pigmented in places, contains numerous glandular and sensory cells (pl. XXIV, fig. 5) covering a middle layer formed of connective tissue fibrils and fundamental substance. Then comes a very strong layer of circular muscle fibers and finally the peritoneal epithelium. There is no permeable lacunar zone as in holothuroids. The migrating cells circulate throughout the body wall without being more abundant at any point. The anchors are completely superficial. The biscuit-shaped corpuscles, to the contrary, are adjacent to the peritoneum and are very numerous especially along the five radial muscle cords.

Pigmentation of the body wall. - I have done very little personal research on pigments that are very interesting in echinoderms. Considerable information and an adequate bibliography can be found in MacMunn (Contibutions to animal chromatology, Quat. Jour. Mic. Sci., vol. 30, 1889, p. 51).

\section{BODY WALL APPENDAGES}

The body wall has numerous appendages in echinoderms that have the most variable functions. These are anchors (synaptids, molpadids), hooks (ophiuroids), spines of all kinds (echinoids, ophiuroids, asteroids), pedicellariae (echinoids, asteroids). It is not possible to categorize them by function because an appendage can have several roles (spines for example).

\section{ANCHORS}

When one looks at a flattened piece of the skin of Synapta inharens, one sees a large number of anchors oriented transversely in relation to the longitudinal axis of the animal. When they are vertical, all the flukes of the anchor are horizontal. None of them are oblique (Woodward and 
Barett, 1859, identified them perfectly). The points of the anchor are sometimes to the left, sometimes to the right. There is no regularity in their distribution.I

The five radial bands in Synapta inhoerens are very often regularly bordered with anchors aligned against each other.

Good figures of the calcareous parts are especially found in de Quatrefages, Leydig, Semper, Luldwig, Semon etc. Their development has been carefully studied by Semon (164). There is less agreement on their soft parts. The basal plates embedded in the connective tissue are held in place by a quantity of fibrils that pass across its meshes in forming a kind of felting. It is bordered on the sides by other packets of fibrils. The terminal part of the fluke and the points of the anchor are covered in a fibrous membrane that projects outside, crossing the epithelial layer. The base of the fluke, as is known, is thick and held in an ingenious cup-like cavity. A large bundle of connective tissue fibrils passes below this base and attaches it solidly to the plate and the surrounding connective tissue in a way that is cannot leave its usual place. I have used various selective stains to carefully look for the muscles that have been reported by several authors and I am convinced that there is not a single muscle fiber as Semper, Semon and Ludwig thought. It is evident that the bundle at the base is only connective tissue and functions as a ligament. As could be expected, the anchor receives no nerve.

The entire part of the anchor that extends from the skin is covered with a membrane as Semper showed very exactly in Synapta Beselii (168, taf. VII, fig. 1). This membrane is bordered by two strong packets of connectiave tissue fibrils that envelope the points. Finally, there are numerous mesoderm cells, often accumulated the length of the flukes. This is without doubt what Semper described at this place in the epithelium. It does not exist as a regular layer. The complete anchor, flukes and points, has a very thin structureless envelope of organic nature quite visible after slow decalcification with acetic acid. The anchor is crossed in the center by a fine canal that Semper and Semon thought filled with organic material. This is quite possible but I must declare on my part that I have not been able to find it after decalcification. A similar central canal exists moreover in many spicules. I have notably found it in the long needles in the skin of Elpida glacialis.

Broken anchors are quite certainly repaired. One often sees them with points that are very small in relation to their other dimensions. Mesoderm cells of the membrane are involved in this case.

Nearly similar anchors occur in all species of the genus Synapta (they are lacking in Anapta gracilis Semper, which completely resembles except for this point, a true synaptid). In Synapta Petersi Semper (coming from Amboine), the anchors are very remarkably asymmetrical and deformed (168, taf. 39, fig.12). Schlulmberger (160) has found in shell sand of the coarse calcite of Chaussy anchors of six species that are completely like those of living species.

Danielssen and Koren described (36) analogous small organs arranged in regular series in molpadids of the genus Ankyroderma (A. Jeffreysii D. and K., musculus Riss, etc.) $\left(^{6}\right.$ ) The basal plate is replaced by an ensemble of five to six spatula-like plates. They are arranged radially around a center and their large ends touch. At the center of this structure arises an anchor completely identical to the finest details of the anchors of synaptids (figures in 114).

Functions. - Opinions differ on their function. Semper thought the anchors could increase tactile power of the skin. This is doubtful because there is scarcely any nervous formation in the region. Semper and Hérouard $(168,73)$ also attributed a defensive role to them. I can no longer take exclusively this opinion because the anchors are completely removed from the animal's control. Moreover, this would scarcely explain their remarkable alignment. If they have a defensive role, it is evidently passive just like any ornament or calcareous plate.

${ }^{6}$ Ankyroderma muscululs, eine Molpadiide des Mittelmeeres, by Ludwig. Zeits. für wiss. Zool. t. 51, 1891, p. 569. 
When a synaptid contacts another body (either dead or alive) the small anchors insert themselves into the crevices of the body and the animal adheres to it in the very remarkable way. This observation made by all authors since Forskål leads quite naturally to think of the anchors as organs of locomotion (de Quatrrefages, Semon). One can still make another remark: when a synaptid is very dilated (both in the living and in preserved specimens), the anchors are erect (contrary to the opinion of Semper) because of the pressure on the body wall produced by the coelomic fluid. In addition, synaptids adhere to all foreign bodies To the contrary, the anchors are flat in contracted zones and adherence is not possible. It seems to me that one can now give a very good account of their function. One knows that synaptids live in sandy beaches in more or less deep holes. When it is quiet, the erect anchors maintain it suspended as by small hooks. When it is disturbed, the body contracts by successive zones, the anchors flatten, attachment ceases and the synapta can thus dig deeper. Semon thought synaptids can suspend their facility of adherence by mucus secretion (164). I believe it is simply by contraction of the body wall that the anchors flatten and the animal can detach from foreign bodies.

The explanation we take agrees perfectly with the consistently transverse position of the anchors. It also explains why these structures occur only in echinoderms lacking ambulacra, such as Synapta and Ankyroderma.

\section{HoOKS}

Hooks, restricted to ophiuroids, are a kind of small fish-hook, about $0.1 \mathrm{~mm}$, more or less toothed and always ending in a very recurved tooth. They are found most specially towards the ends of the arms, the oral surface and nearly all tentacles. Their orientation is constant: the point is directed towards the ends of the arms, sometimes a little outside. They are either articulated with the test (Ophiothrix) or attached to the arm by a membrane (Astrophyton clavatum). Hamann (71) showed small muscular bundles at the base of the hooks. In all species I have examined, these are connective tissue fibrils and not muscles. Nor have I been able to verify the existence of the small ganglianated nerve that Hamann saw going into the hooks of Ophiothrix fragilis.

Hooks exist only in a small number of ophiuroids, especially in species with long spines living on rock bottoms (genera Ophiothrix, Ophiopteron elegans Ludwig). They are always absent in species with smooth arms (Ophioglypha, Ophioderma, Ophiolepis etc.) as well as in those with short arms living on muddy or sandy bottoms (Ophiocoma, Ophiactis, Amphiura etc.). Euryalids, whose arms coil around foreign bodies, nearly always have them (Asteronyx, Astrophyton, Trichaster). In Astrophyton clavatum, the hooks are extremely numerous on the fine branches of the arms. They are found in the figures of Müller and Troschel (131, taf. X, fig.5 and 6), in my memoir on ophiuroids (29, pl. XXVI, fig. 1 and 2) and in that of Hamann (71, taf. 16, fig. 4 and 6). Ludwig showed hooks of Trichaster elegans (99) that he incorrectly called pedicellariae and those of Ophiopteron elegans (112, taf. 35, fig. 10) that much resemble hooks of Ophiothrix hirsute.

Functions. - The hooks are evidently attachment organs, analogous from this point of view to anchors of synaptids. They are very developed in the young. Adult Ophiothrix echinata (Banyuls) often carry very young Ophiothrix on their body, held by their hooks. In adults, they have a passive role in locomotion by implanting themselves into crevices when the arms advance and thus giving it a point of attachment. Their specific distribution and their constant orientation 
in relation to the direction of the arm are evident proofs of this. In euryalids with branching arms, the hooks are extremely numerous and because of their curves, are directed in all directions. This permits the fine brachial arms to attach solidly without muscular effort.

\section{SPINES}

Spines ${ }^{7}$ are test appendages of variable form characterized by their articulation on the skeletal pieces. They exist only in echinoids, ophiuroids, stelleroids and a genus of crinoids. There are two categories to distinguish: $1^{\circ}$ ambulatory and defensive spines that are convenient to separate from glandular spines; $2^{\circ}$ ciliated spines.

$1^{\circ}$ AMBULATORY AND DEFENSIVE SPINES; URCHINS. - It is in the echinoids that they attain the highest degree of differentiation. We distinguish the articulating head that is molded onto a mamelon of the test and the rod that is separated from the head by a pad. The head is attached to the mamelon by ligaments and muscles. First a crown of muscles immediate underlying the epidermis is attached on one side to the circumference of the mamelon and on the other to the bottom of the pad. Second is a crown of more internal connective tissue ligaments that completes the articulation of the rod (see figure of Prouho, 151, pl. XVI, fig. 5). Third is a strong central ligament developed in cidaroids, acrosalinids, diademids, echinothurids, clypeasteroids and spatangoids and missing in echinoids, salinids, arbciadids, echinometrids and cassiduloids. The preceding groups often have small secondary spines. The presence of this central ligament is shown in dry specimens or fossils by the presence of an insertion cavity on the head and another deeper one on the articulating mamelon. It is said they are perforated. The substance of the ligaments is continuous with the organic threads of the mamelon and the spine. The muscle fibers likewise insert on them.

For the makeup of calcareous tissues I shall refer to the works of Mackintosh, A. Agassiz (2, 3 ) etc. The most complicated spines, like those of cidaroids, with a marrow, a middle and an outer layer, go through a series of fixed stages in different urchins. The spines of clypeasteroids and spatangoids, formed of latticed rods, are identical to the characteristic spines of young echinoids. They have thus kept in these groups the most primitive makeup.

Skin and nervous system. - All the basal part of the spine, the head and the beginning of the baguette, are covered by a well developed ectoderm. On the rest of the rod, the ectoderm is fused in part with mesoderm. The periphery of the calcareous stalks has grooves with ectoderm cells that are often ciliated. They are in part mixed with the organic stroma. Prouho and Hamann have carefully described these peculiarities that] are found in all the urchins of our coasts (151, pl. 15, fig. 17 and 18; 69, taf. 16, fig. 10).

The mode of innervation of the spines is now well known following the research of Prouho (151), Sarasin (157) and Hamann (69). The peripheral nerve plexus is located between the ectoderm cells and ends at the base of the spine in a nerve ring, lenticular in section, in the epidermis. The only point I want to emphasize, and it is true for all urchins examined, is that this ring must be considered a ganglion. In fact, the external surface is covered with nerve cells (some of them also have a more or less large number on the internal surface) that are easily distinguished

\footnotetext{
${ }^{7}$ Following the example of most paleontologists, I write radiole as masculine, the word coming from radiolus, petit rayon.
} 
from epidermal cells by their strong staining with boracic carmine. These nerves have a fine extension that soon disappears in the midst of the annular fibrils.

Functions. - It is unnecessary to stress a defensive role to spines, especially those of small size. Some of them are in places that must be especially protected, arranged in a matter to respond to attack by forming an impenetrable wall. Some are found the length of the radial grooves to protect the ambulacra (all urchins), on the periproct (small periproctal spines of Centrostephanus longispinus have striated muscles, Hamann), at the base of large spines (cidaroids), around the genital pores, the terminal tentacles (ocellar pores of authors) etc.

Large spines that must be erected on their tubercles in case of danger make a general defense for the animal. All those who have collected urchins certainly have found this out at their expense. They are not well developed in some animals, asteroids for example, but there are many others that must be distinguished by this spiny system that sometimes is so developed (Phyllacanthus) and forms an impenetrable wall in some species (see the beautiful photographs of Heterocentrotus in Agassiz, 2).

The large spines of cidaroids make up the primary locomotory system (Prouho, Dorocidarisi) as in Arbacia and Caelopleurus (A. Agassiz) and probably many spatangoids and clypeasteroids. In echinids, this role is less although they greatly aid the movements of the animal. The spines around the mouth very often are prehensile for feeding. Finally, it is quite certain that spines (especially in the species with short tube feet) have tactile functions and are sensitive to foreign objects.

Glandular spines of Asthenosoma (Giftköpfchen). --- The Sarasins described (159) a large number of scattered glandular spines in the interradii of Asthenosoma urens. At the top of the calcareous stem (159, taf. 17, fig. 43) is a poison sac (Giftbeutel) covered by a thick muscular layer. The sac opens at the top of the spine. Its contents probably must be injected by them when it enters into contact with an enemy. According to Agassiz (3), imprudent contact with Asthenosoma when it is seized imprudently causes acute pain and slight swelling comparable to sensations causes by physalids.

Crinoids. - Some crinoids have a few short articulating spines on the calyx. They form the genus Arthroacantha Williams (syn. Hystricrinus Hinde), which has only two species, $A$. Ithacensis, found by Williams (185) in the Upper Devonian of Ithaca (New York) and $A$. Carpenteri Hinde (74) from the Middle Devonian of Canada.

Ophiuroids. - Ophiuroid spines are much less developed than those of urchins and occur only some genera. Ophioglypha, Ophioderma, Ophiolepsis, Ophiomyxa, euryalids etc. have completely smooth arms.

Even in the species where they are best developed, their movements are not extensive and are reduced to a rotation on the base. They occur only on the arms in vertical rows often comprising 4 spines of variable size and form. They rarely occur on the aboral disc (Ophiothrix). I except the scales that protect the tube foot pores.

In Ophiocoma scolopendrina that, thanks to its great size, is a good subject to study, when a spine is detached from its articulating mamelon, two holes very close together are seen. A central muscle is inserted into the larger, very deep one. A nerve passes through the second smaller one and continues through the test. The spine is attached to its mamelon by a thick circular ligament arranged like that of urchins. It is inserted on the circumference of the mamelon and the articulating head by a central muscle. This is inserted on one side into the deep hole in the mamelon and continues on the other side with a ligament that enters the spine (pl. XXIV, fig. 7). This central muscle is very clear in the spines of Ophiocoma scolopendrina, Ophiothrix fragilis and in some 
Ophiactis virens. It is sometimes entirely replaced by a strong central ligament (Ophiactis virens, Amphiura squamata).

There is no differentiated ectoderm on the spines except sometimes at the base. As in the rest of the test of ophiuroids, this layer is entirely mixed with calcified mesoderm. The nerve comes from the peripheral branch from the radial nerve band (fig.33 and 36). Where the spine nerve goes into the mamelon, it is swollen into a small ganglion bordered on the periphery by numerous nerve cells. This ganglion is evidently homologous, from the functional point of view, with the basal ring of urchin spines. From the ganglion leaves a very large nerve that is entirely fibrillar. It goes through the mamelon and enters into the spine. After a short distance, it divides into fine branches that run on the organic mesh of the spine towards the periphery.

I described for the first time the innervation of the spine in 1888 (29). Hamann confirmed my observations without citing me in 1889 (71). I found the basal ganglion and the nerve in all species having spines that I have studied (Ophiothrix, Ophiocoma scolopendrina, Ophiactis virens, Amphiura squamata).

Functions. - Spines do not function in locomotion in ophiuroids. Moreover those bordering the oral surface are always the smallest. The central muscles fill primarily the role of a very elastic ligament, attaching the spine solidly to its mamelon. Outside their defensive function that can have a certain importance (Ophiothrix hirsute and echinata, Ophiacantha setosa etc.), the spines have primarily a tactile role. They inform the animal on the form of cavities into which they introduce its arms, on the foreign bodies they contact etc. It is necessary not to forget moreover that a large number of ophiuroids totally lack spines. I shall cite only the remarkable palmate spines described by Ludwig in Ophiopteron elegans (from Amboine, 112). Each vertebra of the arm has a true membranous fin whose rays are formed by fine calcareous spines. Ludwig thought Ophiopteron, which is very near Ophiothrix, can use these appendages to swim. The presence of hooks makes this hypothesis unlikely. It will be necessary to observe the living animal to resolve this question.

Glandular spines. - As abnormal forms I hardly ever see cited, the Keulen-Stacheln or clubshaped spines of the genera Asterochema Ltk., Ophiocreas Ltk., Ophiomastix M. and Tr. These spines are found on the arms, mixed with other spines. Müller and Troschel (131) give a very reduced figure of them in Ophiomastix annulosa. Lütken and Brock noted them in nearly all species of Ophoimastix.

According to Hamann who studied them (1889), the end of these spines is covered by a very thick epithelium reported previously by J. Brock. They are richly innervated and enclose many glandular and sensory cells. Ludwig $(1890,115)$ confirmed the existence of a thick inter-epithelial nervous layer coming from the radial nerve. The epithelium is formed of glandular cells and unspecialized cells (not sensory, as Hamann said). Nothing is known of the physiology of the Keulen-Stacheln because all species that have them are exotic. It is possible they are a glandular defensive system like the glandular spines of Asthenosoma.

Asteroids. - Asteroid spines are always very small and very variable in form. They are usually immobile on the aboral surface. On the oral surface, those that protect the nervous system, the tube feet, the terminal tentacles etc. have, to the contrary, muscles and are very mobile. I shall take as an example the spines that border the ambulacrum in Asterias glacialis (pl. XXIV, fig. 8).

Strictly speaking, there are neither mamelon nor articulating head nor differentiated ligaments. The spine is attached to the test by ligamenous fibers uniting the organic network from one to the other. There are two muscle masses. One is very dense (depressor muscle). The other is formed of longer but fewer fibers mixed with ligamentous fibrils (erector muscle). The entire spine is covered with a thick layer of fibrillar connective tissue and of ectoderm with many glandular cells. There 
is scarcely any part on the end of the spine that the calcite is not covered. There are no special differentiated nerves as in the spines of urchins and ophiuroids. The intraepithelial nervous layer, very thick on the side where the spine is depressed, becomes very thin in all the epithelium covering it.

The spines of the aboral surface Asterina gibbosa are in small groups of two, three or four (Norman, Perrier), united two by two by a sheath of transverse muscular fibers. These spines are susceptible of coming together when irritated, a little like pedicellariae but their movements are not so active and their efficiency as prehensile organs must be very weak. They move because of the elasticity of their ligaments. There are no abductor movements. This is a very interesting case because it shows (with many others, notably Archaster, see Perrier, 143), how the pedicellariae were made primitively by adaptation of spines joined in small groups like those of Asterina. If Darwin had known of this fact, he would have had another good argument to counter Mivart who had supposed that one could not conceive of the production of pedicellariaie by the hypothesis of natural selection. ${ }^{8}$

The paxillae of Astropectinidae are made up of a small column fit into the test and having small radiating spines at their end that are more or less mobile according to species. These can be lowered horizontally in a way to protect the papilae located in the intervals between the paxillae (see 28, $\mathrm{p}$. 29). All of the paxilla is covered by ectoderm and has many mucous and granular cells. The superficial nerve plexus, which is very thick between the paxillae, is very thin in the covering epithelium.

$2^{\circ}$ CiLiATED SPINES. - This category indicates generally very small spines with no defensive or ambulatory role that have a very developed ciliated epithelium.

Asteroids. - The most characteristic type is found in Luidia ciliaris and in a certain number of Astropecten reported by various authors (Sladen, Cuénot etc.). On the lateral surface of marginal plates is a covering of small spines. These spines are connected to them by connective tissue fibrils and some muscular bundles. They have a delicate calcareous skeleton covered by a tall ciliated epithelium (28, pl. I, fig. 19). I think these numerous ciliated spines, about $0.5 \mathrm{~mm}$ in length, cause a current of water that renews oxygen around the papulae hidden under the paxillae.

Sladen (173) described "cribriform organs" in several related genera, Porcellanaster, Hyphalaster, Styracaster and Thoracaster. They probably fall into the same category as the ciliated spines of the marginal plates. These small, very complicated organs are variable in number. They are always located on marginal plates in the interradius.

I note here a statement of Agassiz (3, page 13): "I have also shown the presence of such rudimentary fascioles in Starfishes... etc" He refers to Contr. Nat. Literature History U. S., vol. 5, 1865. I have not been able to obtain this so I do not know what he is referring to.

Echinoids. - The semites or fascioles of spatangoids are covered with ciliated spines (clavules of Lovén) that are set apart by their small size (about $2 \mathrm{~mm}$ ) and their delicacy from the surrounding large spines. The spine of the fasciole has a lattice-like calcareous skeleton at the center and is slightly swollen at the end. It articulates to the test like a large spine, with a small central ligament, a circular ligament and a circular muscular layer. The skeleton is covered by a tall, very ciliated epithelium. It contains a thick layer of nerve fibers as Hamann (69) recognized well but has no differentiated nerve ring at the base of the spine.

Fascioles occur in all extant anachytids except Platybrissus Grube and in some fossils of this group. All extant spatangoids have them. The arrangement of these bands is very variable, sometimes even in individuals of the same species (Agassiz). They are of great importance in

${ }^{8}$ Origine des espèces, Reinwald, Paris, 1873, p.443. 
taxonomy and have even been used in artificial classification (Lutken). But whatever be their variation, they exist only in two locations: near the anus and around the petaloid zone. All the necessary details on their form is found in the works of Lovén (117) and Agassiz (2, 3).

Functions. - As Lovén (117) remarked, fasciolar spines are extremely sensitive, which is related to the thick nerve layer at the base. When one is touched, nearby ones also move. Agassiz though fascioles function to stop movement of mud to protect the petals against foreign material. Koehler refuted this opinion, noting that there was always just as much mud in the fascioles as in the petaloid zones. For my part, I believe the fascioles cause a more or less strong ciliary current that renews the water across the mud that covers the animal. This is the reason they surround the petaloid zones (peripetal fasciole, etc.). It is clear that renewal of water is related to respiration of the tube feet of the petals. This agrees perfectly with the statement of Agassiz: "... the spatangoids with peripetal fascioles also have the most petaloid ambulacra" (3, p. 14); i.e. the most differentiated from the respiratory point of view.

For the fascioles that surround or are close to the anus (infra-anal or lateral fascioles, etc.), it is very possible the water current removes from the test sand ejected constantly from this opening.

Clypeasteroids. - The aboral surface of Echinodiscus biforis (Red Sea) is covered with a myriad of small spines forming a velvet-like covering. These spines are ciliated, a little less massive than those we just discussed, forming as it were the way to true spines. They are articulated to the test as usual with a central ligament and a circular ligament and muscles. The calcareous skeleton is covered with a tall epithelium with very long cilia. It is swollen at the end as in spatangoids. A ganglionated nerve ring is found at the base of the spine.

This special covering, which is well developed only in a small number of clypeasteroids, probably cleans the test and to produce a water current around the respiratory tube feet of the petals.

Ciliated spines probably occur in many other urchins, but it is indispensable to examine them fresh and not from tubercles of insertion. This is the reason I cannot accept without reservations the comparison of Agassiz (3) of fascioles with rows of military tubercles existing in various Phormosoma.

\section{PEDICELLARIAE}

Pedicellariae are small prehensile organs that occur in all echinoids and some asteroids.

Urchins. - The numerous forms of pedicellariae have been classified into four slightly artificial groups (Valentin, O. F. Müller, Perrier etc.), connected to each other by form of connection.

$1^{\circ}$ Gemmiform pedicellariae: three more or less long valves articulating on a stalk with sharp tips. The convex part of these pedicellariae have glandular valves with mucus that is probably venomous (Sphorechinus, Echinus, Strongylocentrotus, Toxopneustes, Hipponoe, Dorocidaris etc.) and sometimes with mucous glands along the stalk (Spharechinus, Echinocardium etc.) (P. Sladen, Fættinger, Hamann). They are sometimes tetradactyl in Corocidaris papillata (Stewart).

Globiferous pedicellariae are attached to the gemmiform pedicellariae (Hamann, Duncan). These are pedicellariae whose terminal part is atrophied (the calcareous vales are small) and there remains only the stalk and three mucous glands (Centrostephanus, Sphorechinus). Headless 
claviform pedicellariae that Fættinger reported in Diadema setosum (51) are also globiferous pedicellariae. Good figures of these are in Hanann's memoire (69).

$2^{\circ}$ Tridactyle pedicellariae: long stalk with three long and very thin valves, more or less ended in spoons. They are never glandular but, in contrast, reach often reach a very large size. To this form are attached the tetradactyle pedicellariae of Phormosoma fenestratum W. Thomson and of certain spatangoids, Schizaster canaliferuis (Kæhler, 87) and Pourtalesia carinata Agassiz.

$3^{\circ}$ Ophiocephalus or buccal pedicellariae, found on the buccal membrane, short stalk with three short and massive valves.

$4^{\circ}$ Trifoliate pedicellariae, scattered all over the test of the urchin, with a thin stalk and three short valves enlarged at the top.

Pedicellariae of urchins, particular the gemmiform, are extremely complicated organs, with muscles that are sometimes striated and ligaments, tactile mamelons (tactile cushions discovered by Sladen, 171, numerous nerves etc. I can only confirm the nice works of Hamann. I have verified most of the histological results that allow little hope of going further into his analysis of these interesting organs (69). For the calcareous parts, figures of them are found in Perrier (183), Kœhler (87), Agassiz (3) etc.

It is in regular urchins, and especially in those of large size, the pedicellariae are most developed and of most varied forms. In spatangoids, complexity is much less and finally, in clypeasteroids, each species has only one or two forms of small and relatively simple pedicellariae that greatly recall trifoliate pedicellariae of the regulars.

In the latter group, Agassiz was the first to report them in three species (Echinanthus rosaceus, Clypeaster subdepressus, Echinarachnius parma). I have also found them in Echinocyamus pusillus, Echinodiscus biforis and Peronella orbicularis. They are relatively simple, small and not numerous on both test surfaces. In Echinociamus (pl. XXIV, fig. 9), they much resemble those of Echinanthus rosaceus (2) and certain spatangoides (Echinolampas). The stalk is very short and ends in a kind of sunken cup. On the border of the cavity are attached three valves connected to the stalk by three muscles. The values differ in form. One has a very large basal part on which articulates the two small valves. In Echinodiscus biforis, these are the small trifoliate pedicellariae whose three valves, enlarged above and finely toothed, are connected to the stalk by a long connective peduncle. In these two species, there is also a second form of small tridactyl or tripholis pedicellaria found everywhere on the oral surface.

Asteroids. - Pedicellariae of asteroids, lacking in some species (Astropecten, Cribrella etc.), are much simpler than those of urchins. Nearly always didactyl (except in Luidia and some Asterias glacialis), they articulate directly on the test or at least are never at the end of a stalk as in urchins. The calcareous plates are shown well in the memoir of Perrier (138). For histology, I refer to my memoire of 18887 (28), whose results I have verified.

Morphological value of the pedicellariae. - Pedicellariae of urchins and asteroids are certainly not homologous organs in the strict sense because the do not come from the same ancestral form. They developed independently in the two groups, attaining a high degree of differentiation and generality in urchins, much less specialized in asteroids. As Agassiz particularly showed, pedicellariae are adaptations of spines that differ in the two groups.

In asteroids, when a pedicellaria develops (28), there appears first in the founding mamelon two calcareous blades that are the future valves. As a result, the pedicellariae are two coupled and transformed spines. We can also find nearly all the transitions between normal spines and the most differentiated pedicellariae (notably in Asterina, Archaster, Culcita et al., according to Perrier).

In urchins, there are likewise three valves that appear first. The stalk forms only secondarily. 
As a result, as Darwin thought, pedicellariae are first sessile, originating first by the combining three spines. Later, by an improvement extending their zone of action, the common pedicel is extended and at its interior is developed the calcareous stalk. It is to be noted that this is lacking a ganglionated nerve ring characteristic of spines. Only, as in asteroids, there are sufficient transitional forms to follow the phylogenetic evolution of pedicellariae, those completely lacking in urchins, all these organs show nearly the same degree of evolution.

We shall consider the functions of pedicellariae in the chapter of "Means of defense".

\section{CUVIERIAN TUBUles}

The tubes of Cuvier, found in a small number of holothuroids, are whitish caeca attached in large number to the wall of the cloaca in addition to the respiratory tree that can be ejected outside voluntarily. I have studied them in Holothuria impatiens. I confirm in large part the results of Jordan in this species and those of Hamann in Holothuria Poli. The best procedure to use is to make longitudinal sections of the tube still fixed to the cloaca as shown in fig.19, pl. XXIV.

A Cuverian tubule is formed from a slightly swollen basal vesicle. It is a simple diverticulum of the cloacal wall and a glandular tube that can be ejected. The latter, in the normal state, is folded into a spiral-like screw, following the quite appropriate expression of Hérouard (73). It has an external glandular epithelium, a connective tissue and muscular zone and an internal epithelium lining the lumen of the tube, which is greatly reduced and spiral.

The internal epithelium, which is formed of large granular cells, has a very unusual appearance. It does not appear to have a very important role in the functioning of the tube or, to be more exact, the function has not been clarified.

The connective tissue layer is extremely thick. It is formed of fine, separated fibrils strongly colored by carmine and methyl blue. It folds onto itself in a way to make a kind of cylindrical spring with very tight coils. From the periphery of the helix are detached bundles of fibrils, directed nearly perpendicularly to the external epithelium and appearing to be inserted between its folds. All these details are shown very well in the figures of Jourdan (86).

The circular and longitudinal muscle fibers form separate bundles. They are in the connective tissue zone at the edge of the spiral and radial fibrils. The more external longitudinal bundles are formed of eight to fifteen fibers connected together. The more internal circular bundles are composed of only two connected fibers and do not form at all a continuous layer that Jourdan described incorrectly. Hérouard thought the circular bundles in Holothuria catanensis formed a single spiral muscle extending from one end of the tube to the other and able to compress or extend like a spring. I think it is the same in Holothuria impatiens.

The glandular epithelium, perfectly described by Jourdan, is formed of flat cells (grooved cells), folded in two by contraction of the tube. They are filled with granules strongly stained by carmine that appears identical to the granules of muriform cells I described in the ectoderm of asteroids. Below this glandular epithelium, Jourdan and Hamann described a thin flat epithelial covering, ciliated according to Semper (168). In my sections, I have not been able to clearly come to this view. The spots one often finds at the periphery of the tube seem to be amoebocytes in the wall. The grooved epithelium totally disappears a little before the basal vesicle and is replaced by the usual peritoneal epithelium (pl. XXIV, fig. 19). 
The basal vesicle, which Semper showed clealy in Bohadschia marmorata Jåger (168, taf. 37, fig. I), is slightly ovoid. Its internal cavity is nearly entirely obliterated by a mass of connective tissue cells that appear continuous with part of the Cuvierian tubule. The wall of the vesicle has a thick continuous muscle layer formed of circular and longitudinal fibers. The latter make up the insertions of the fibers of the tube. All is covered by the peritoneal epithelium.

Packets of yellow granules (excretory products) are often found in the vesicular walls. They are rarely in the tube itself. Migratory amoebocytes are found in very small number under all the connective tissue layer.

It is certain the makeup of the Cuvierian tube is very complex, but it seems to me that it can be considered in this way: Imagine a central spring formed of connective tissue fibrils so the turns are applied against each other because of the presence of a muscular network that completely encloses them. The mesh of the network is made up of the longitudinal packets and the muscle spring. The interior cavity becomes filled with water to elongate the tube. The external epithelium is transformed into inflexible and sticky mucus when it has been exposed and unfolded after extension of the tube.

Ejection of the Cuvierian tubules. Let us now examine the process of ejection that is produced when the holothurian is irritated. As Hérouard has shown, water in the cloaca enters the basal vesicle and from there gradually into the tubes that are dilated little by little. This dilation coincides with the contraction of the irritated animal. The pressure in the interior of the body increases. The tubes tend to be ejected outside. At this moment there is a point that escapes direct observation. They are broken at their base of insertion on the basal vesicle that probably is the point of least resistance, crosses it and the cloaca and are ejected outside by the anal opening. When the basal vesicle is contracted, the powerful muscular walls are applied against each other and interrupt all communication between the coelom and the exterior. When the ejected tubules are examined, there are as many small contracted furrows found on them as on the basal vesicles.

When the tubules are ejected into the surrounding water, they undergo curious modifications. The longitudinal muscles are broken as they are inserted on the basal vesicle. The muscle spiral also is unwound. The dissociation of the muscle network causes the connective tissue spiral also to unwind to produce a tube that is twenty and thirty times longer. The external epithelium unfolds and is transformed into an extremely tenacious sticky material so that the Cuvierian tubules attach to all objects it contacts. A little later, the connective tissue fibrils themselves dissociate and separate from each other, forming a skein of extremely fine entangled threads.

Cuvierian tubules are found only in some molpadids and some aspidochirotes. Among the European species, they are found in Holothuria impatiens Forskal (Mediterranean), catanensis Grube (Mediterranean, Atlantic Ocean), Poli Delle Chiaje (Mediterranean), and nigra Font. (English coast). Ludwig (114) lists exotic species with Cuvierian tubules.

Functions of Cuvierian tubules. --- Semper (1868), after having refuted the opinions of Leydig, Müller, Carus, and Jäger, who thought the Cuvierian tubules were excretory organs as Gegenbaur did later, attributed a defensive role to them. Bell, Greeff and Jourdan adopted this view. Hérouard (1890) recently raised objections to this interpretation, wrongly we believe.

All that we know about Cuvierian tubules prove they are certainly defensive organs.

$1^{\circ}$ Their so singular makeup agrees perfectly with this point of view. They are not glands because the epithelial covering is external and corresponds to peritoneal epithelium. There is no excretory product nor any possibility of evacuation even if it existed. They are not at all transformed respiratory trees (Hérouard) because these exist perfectly developed and normal beside the Cuvierian tubules. Finally, the granular cells that play so important role in production 
of adhesive material greatly resemble the muriform cells of the ectoderm of asteroids (see 28) and it is difficult not to give the latter a role as defensive glandular cells.

$2^{\circ}$ Ejection of the tubules, according to Hérouard, "is only the first act of evisceration when the animal is in bad conditions. When the wall of the cloaca begins to rupture, the Cuvierian tubules that are the organs closest to this site are involved and extended into the surrounding water etc. (73, page 140)". This is not the opinion of Jourdan or mine. I have had a Holothuria impatiens with an intact gut attached to the cloaca that had only seven or eight tubules. It had thus ejected many of them (this species, according to Jourdan, has nearly a hundred of them). Some of them were even in the process of leaving the anus. Cuvierian tubules, when the animal is irritated, can certainly be ejected in very large number without the gut showing the least indication of rupture. It is only later, if it occurs, that the gut is, in its turn, ejected and not connected correlatively to that of the Cuvierian tubules.

$3^{\circ}$ Among the observations related to the action of the ejected tubules, I have only the report of Peach $(137,1845)$, a little suspect as the author did not know Cuvierian tubules existed (it was then confirmed by Bell for the same species, 13). Holothuria nigra Font., common in Ireland and on Cornish coast in rock holes, is called by fishermen cotton spinner because of the long threads it ejects. "It is extremely irritable and when it is touched or disturbed ejects a tuft of white threads a thumb long and an eighth of a thumb wide... These are soon are attenuated, either by the agitation of the water or the contact with a foreign body and become very long threads of a great tenacity. They adhere to anything they touch and for that reason fishermen call them cotton spinners. This small packet becomes a great mass of threads, finer than the finest cotton sewing thread. There is no doubt they are defensive used to protect the animal. I have seen a crab so completely wrapped up in the threads that it could not move and a fish that could free itself only after a long fight. If the holothuroid is very irritated, it ejects the entire gut. This invariably happens when they are kept in aquaria for two to three days, etc."' (pages 173-4). Not only the tubules, whose connective tissue fibers quickly dissociate, form an inextricable network that entangle the assailants, as Peach noted, but they are extremely sticky, thanks to the tenacious mucus produced by the peripheral cells. It is extremely difficult to separate them because they adhere to everything they touch (Jourdan).

It seems to me thus proven, for all the reasons I just enumerated, that the singular Cuvierian tubules are certainly defensive organs and nothing else. New observations on this subject would be far from superfluous. Unfortunately, the holothuroids that have them are very rare on our coasts and it is difficult to acclimate them sufficiently in aquaria to be able to experiment in nearly normal conditions.

\section{MEANS OF DEFENSE}

This is a chapter particularly difficult to write. Except for some organs, observations that have been made are very incomplete. To do it well, it would be necessary to observe the animal in its normal environment and see how it behaves towards it natural enemies. This second part of the program is very difficult to do. Also to supplement it with experiments that are not a little artificial.

Synaptids. - Except for their commensals and numerous parasites (a gregarine, Syncystis synaptce Ray-Lank., some receolarian infusorians, Trichodina synaptce Cuénot that are very abundant in the coelomic flud; perhaps a rotifer reported by Ray Lankester; some mollusks, 
Entoconcha in the synaptid Entocolax Voit in Myriotrochus etc. $)^{9}$, I do not see how synaptids that live buried in sand could have enemies. The anchors surely are not important as organs of defense as Semper and Hérouard thought. The special mucus (?) they can secrete when excited (see chapter on the nervous endings of the skin) perhaps act in this sense, but in all cases it does not prevent various animals (infusorians and several rotifers such as Discopus synapta Zelenka ${ }^{10}$ from establishing themselves on the skin.

According to Semon (164), Synapata hispida and digitata in general have the same color as the sandy bottom where they live. This makes it possible to think these animals spend a certain part of their life on the surface. It is not certain this is true for Synapta inharens that always has the same pink color wherever it is found.

Finally, various authors think synaptids can escape their enemies by autotomy. I do not believe this is a very normal act in these animals. Autotomy occurs especially when synaptids are in bad situations, starved or half asphyxiated. In this case, it is a pathological phenomenon without a defined function. It occurs in the same conditions in various Phascolosoma (Ph. elongatum Keferst.). It would be important to define what conditions produce autotomy and to see if it losing a wounded part really is a defensive mechanism. For my part, I have observed nothing like that.

Holothuroids. - Holothuroids often have a very well developed covering (Elpidia glacialis). The thick coriaceous body wall can defend very well against attacks. But true defensive dispositions exist only in some aspidochirotes. We know neither what can defend dendrochirotes against predators nor even what their predators are.

Aspidochirotes can be attacked by fish, crabs etc. Those with Cuviereian tubules eject them at the least wounding contact in such a way their stickiness hinders the assailant. As for ejection of the viscera by most Holothuria and Stichopus, is it necessary to consider it a defensive mechanism? The holothuroid would furnish thus an easy prey to the assailant in such a way to satisfy it and to save the rest of its body and moreover repair the lost part easily. As extraordinary as this appears, it is certainly possible. It must be noted that if the ejection of viscera occurs nearly always when the animal is disturbed, it also occurs spontaneously when the animal is kept in captivity under bad conditions.

Nothing is known of the phenomena or mimicry and protective coloration in holothuroids, whose colors are generally not bright.

Crinoids. --- Autonomy is the sole defensive mechanism in comatulids. Preyer (150) showed electrical shock causes the arms to fall one after the other, just like pinching them with forceps. $37-38{ }^{\circ} \mathrm{C}$ sea water has a still more marked effect. Not only do the arms detach from the disc and are broken into many pieces, but the pinnules themselves separate from the arm. These observations are interesting but it is necessary to admit completely artificial. Frequently incomplete arms are found in specimens. This is probably the result of a true defensive autotomy but we completely lack indisputable observations.

It is the same for evisceration. It is known (Carpenter, Marshall, Dendy) that it is possible to completely remove the visceral sac of Antedon so that only the arms and calcareous calyx remain without the animal dying (under good conditions). It continues to move as if nothing had happened.

\footnotetext{
${ }_{9}^{9}$ Protozoaires commensaux et parasites des Echinodermes, Revue bibliogique du Nord, t. 3, $1^{\text {er }}$ mai 1891.

${ }^{10}$ (C. Zelinka. Studien über Raderthiere, II. Der raumparasitismus und die Anatomie von Discopus synaptæ, n. g. nov. Sp., Zeits. Für wiss. Zool., t. 7, 1888, p. 353.) Zelinka described this commensal rotifer attached to the skin of Synapta digitata from Trieste. I have discovered another commensal rotifer in Synapta inhærens from Roscoff that I have not examined with care. But it seems to me identical to Discopus. Ray Lankester reported a rotifer in the coelom (?) of synaptids from Guernesey.
} 
The lost parts regenerate little by little. Dendy (38) saw a complete visceral mass, although small and not greatly pigmented, regenerate in 21 days. Dendy though evisceration and subsequent regeneration could occur naturally to remove either dangerous parasites or "poisonous particles". The fact is that eviscerated Antedon are frequently found at the seashore (Roscoff). H. Carpenter (21, p.67) reported Challenger collected a certain number of Actinometra and Antedon lacking a visceral sac. The so-called recent cystid (Hyponome Sarsii) described by Lovén, is nothing else than a visceral sac of an Antedon, common at Cap-York, detached from the calyx (H. Carpenter). There would have to be experiments tried in this way with Myzostoma. However Antedon does not seem to profit much from their ability to eviscerate Myzostoma, Stylina and crustaceans that are often attached to their disc.

Echinoids. - Many fish are fond of urchins, among others cod (Agassiz), Gadus aeglefinus (Giard), Mugil (Prouho) etc. Asteroids readily eat them. Urchins are well protected by their thick skin bristling with small and large spines so well adapted to protect delicate organs. In echinothurids with a soft skin, the spines have poison glands (described by Sarasin in Asthenosoma urens). It should be pointed out that nearly all echinothurids have spines ending in an enlarged muscular extremity (-- sheathed spines). These also are probably protective. According to Agassiz (3, page 71), "It is quite dangerous to handle these specimens when alive (or even in spirits); the wounds they make with their numerous sharp stinging spines producing a decidedly unpleasant sensation accompanied by a slight numbness, fully as painful as that occeasioned by the stinging of a Physalia." In contrast, no special defensive structures have been described in other urchins with a flexible body wall (Astropyga, Cystechinus).

As Darwin thought, pedicellariae and particularly the glandular pedicellariae are very perfected defensive organs that, to be exact, bite a little to hurt and penetrate. It is sufficient to put fish, mollusks etc and urchins in the same aquarium. The former soon have pedicellariae on their surface torn from the test. No matter what part of the surface is touched, not only do the spines respond for protection but the pedicellariae of the region point towards this point and seek to bite the assailant.

Prouho (153) recently described a fight between a Strongylocentrotus (or Sphaeerechinus) and an Asterias glacialis and the tactics used to unmask, not its batteries, but its pedicellariae. Each time one of them bites the asteroid, it draws back detaching the pedicellaria but soon returns to the charge. When the urchin has exhausted its supply of attack appendages the starfish ends by winning the victory.

Regarding mimicry or protective coloration, we know nearly nothing. The fragments of shells, pieces of algae etc. that several urchins (Sphorechinus granularis, Strongylocentrotus lividus, Echinus microtuberculatus) maintain on the apical pole or against the test in the middle of the ambulacra serve either to dissimulate (see Dohrn's observations on Spharechinus, 39) or perhaps to protect them against unexpected attack (Strongylocentrotus).

It is curious to note as Agassiz did that spatangoids and clypeasteroids, that represent in some ways higher types than regulars, are the least powerful of all urchins from the defensive point of view. Their pedicellariae are small and not numerous and the spines are very weak. They can move only very slowly. The test is relatively fragile in spatangoids, sometimes even flexible as in Cystechinus. The only resource consists of burying into the sand to escape detection by their enemies. It is not impossible the cause of their great organic differentiation must be sought in their poor defense, all the organs being adapted to the subsurface life.

Ophiuroids. - Ophiuroids are sufficienctly protected by the calcareous body wall and their spines (sometimes glanular, Keulen-Stacheln). They have only one well known defense, autotomy. 
It is sufficient to leave Ophioglypha or Ophioderma with asteroids, fish etc. in an aquaria to find the next day either ophiuroids more or less amputated, fragments of dead arms here and there and partly eaten. If an Ophiothrix is held a little brusquely by one of the arms or pricks it with a needle, it autotomizes and the rest remains in the hand. Preyer (150) has made very interesting observations about ophiuroid autotomy. If a rubber band is placed around the arm of an Ophioglyipha, the animal first tries to remove it by oscillatory movements. Then, if it cannot, the arm autotomizes at its base. It is important not to confuse this evasive autotomy (following Girard's happy expression, 58) with reproductive autotomy of various ophiuroids (notably Ophiactis virens) that is not at all related to defense.

In general, ophiuroids are not brightly colored and some are nearly the same color as the bottoms on which they live. Ophioglypha albida and lacertosa, which live in sand, are whitish. The color of Ophiothrix fragilis varies greatly according to the bottoms where they are found. Protective coloration can preserve ophiuroids to some degree from their enemies. The species of our coast will have to be examined in this regard with more care than I have done. It is necessary to remember moreover that living animals are often buried in mud or sand or in rocky cavities where it is very difficult to reach them.

Asteroids. - Asteroids are the best provided from the defensive point of view of all echinoderms and I can even say without contradiction of all marine invertebrates. No matter which animal is put into an aquarium, mollusks, annelids, crustaceans, coelenterates, etc and Asterias glacialis, it is certain that sooner or later the latter will eat the others without taking care of spines, bristles, pinchers, mucous glands, etc. Not only are they well provided from the defensive point of view but they appear moreover completely indifferent to the processes employed by the other animals. Even the nematocysts of coelenterates appear to have no effect on them. In the various combats observed in aquaria, I have never seen an animal attempt to attack an asteroid in good condition.

All defensive means are accumulated in asteroids. In addition to their calcareous body wall, usually not very mobile it is true (except in the case of paxillae of Astropecten) the body wall skin has a considerable quantity of mucus and muriform cells (see 28) that secrete an abundant very sticky mucus that has a special odor. It is quite probably venomous. ${ }^{11}$ Echinasster sepositus has this arrangement to a high degree. The skin as true mucous glands in the body wall in considerable number and releases a very dense mucus at the slightest touch (see 28). It should be noted that Echinaster sepositus, which has only these glands for defense, lacking spines and pedicellariae, have a bright color, an intense red. It is an example of aposematic coloration, as is often present in animals defended by secondary metabolites (Heliconia according to Wallace, Eolis, Herdman, a large number of caterpillars and insects, certain Gasterocanthida among araneids etc.). Echinaster appears very well protected by its mucus glands because it is one of the species of the littoral that rarely has lost an arm. Examples with incomplete arms are relatively rare.

To document this I cite the experience of Parker $(136,1888)$ that tends to prove Solaster papposus contains sufficient venomous products (leucomaine) to cause the death of small animals:

\footnotetext{
${ }^{11}$ It should be noted this secretion does not prevent various commensal infusorians from establishing themselves on the skin of asteroids. Frequently found on Astropecten squamatus from Banyuls is an urceolar Licnophora Auebachii Cohn, previoius found by Gruber on asteroids and by Fabre-Domergue on Opohiothrix. The latter author described an infusorian on the papulae of Asterias glacialis. (Etude sur l'organisation des Urcéolaires, Journal de l'Anat. et de la Phys., t. 24, 1888, p. 124. Uronema digitiformis F. Dom. sometimes live on the skin of this latter species. Cyclochaeta asterisci Gruber is a commensal on the papulae of Asterina gibbosa.
} 
two cats, one young, the other adult that ate a Solaster. The younger died after 15 minuites, the second in two hours.

The pedicellaria, still more than in urchins, efficieintly protect asteroids that have them. I refer to my memoir of 1887 for the experiments regarding their functioning (28). They can be very unequally developed in the same species according to the source of the individuals as I have shown for Asterias glacialis of our coasts. Sometimes even in extreme cases (Gymnasteria, Luidia) the form and the distribution of the pedicellariae showo great differences. The environmental conditions evidently have a great affect on the number and sometimes the form of these organs.

Finally the asteroids (except those that are nearly globulous like the culcites) readily autotomize diseased or attacked arms. Sometimes autotomy is spontaneous because the animal is in bad environmental conditions or has been damaged during dredging. Luidia ciliaris shows this phenomenon to so high a degree that is very rare to dredge a complete specimen. There are always some arms in process of fragmenting. Asterias rubens and glacialis break the arms at the edge of the disc, especially when removed from water (see Preyer 150). Very often one finds specimens of these species reduced to the disc and a single arm, the four others being in the process of regenerating (comet-like forms). According to Preyer, the arms of Ophidiaster ophidanus also detach at the disc edge. Echinaster, Cribella, Asterina, Solaster, Astropecten, etc. equally show autotomy but less frequently. The arms break at a point anywhere along their length. It is to be noted that autotomy of asteroids and ophiuroids appear to be most often voluntary and not at all a reflex as in decapods crustaceans, sauterians and lizards (Fredericq, Contejean, etc.).

In all the asteroids of our coasts that I have been able to examine sufficiently, the isolated part after having survived a more or less long time, up to a month, ends by gradually disintegrating. The surface of the remaining section is completely sealed. It is important to clearly distinguish between this evasive autotomy, a truly defensive act, and reproductive autotomy or schizogony that produces in some asteroids under a completely different influence. The first results in a loss to the animal while the second results in the formation of a new individual. In general, authors, Simroth, Pryer and others have confused these two processes that are very different in cause and result.

\section{BODY APPENDAGES}

I include under this title the cirri and stalks of crinoids as well as the various formations of the asteroids; the body cavity is extended into their interior. They are true limbs.

The histological makeup of the stalk and cirri is now well known. At the center is an extension of the enterocoel (chambered organ) divided into five chambers in the stalk of true crinoids, into two in the cirri of Antedon etc, by small connective tissue septa. Around this cavity is a thick nervous layer, extending from the neural cup that surrounds the chambered organ. Finally all these pieces are united, not by true muscles, but by bundles of tissue with the appearance of connective tissue (hyaline muscle of Perrier) that we studied before. However the stalk (Agassiz, Förste) and the cirri can move, very slowly to be sure. Ample details and good figures are found especially in the works of H. Carpenter (21), Perrier (145) and Hamann (71).

Ontological and phylogenetic development of the stalk and cirri. - The stalk first appears in the ancestors of the Pelmatozoa, from which it was transmitted to cystids, blastoids and crinoids. It is certain several cystids lacked the stalk, either completely free (Lichenoides priscus Barr. and 
Prodocrinites oviformis Eich.) or fixed by their base on foreign bodies (Agelacrinus, Echinospharites). In the other cystids, the stalk is in general very short and does not appear to serve as an organ of fixation. In fact, it becomes thin near the base and has no thickening or root extension (Zittel). Perhaps these animals simply lived buried in mud by their apical extension.

It does not appear doubtful, and is I believe the opinion of all paleontolgists, that the stalk arose gradually by extension from the point of fixation (dorso-central plate). It then divided into superimposed pieces and with attaching appendages (roots of the base or cirri: the stalk is thus a dependence of the apical pole, intercalated between the dorso-central piece and the rest of the calyx.

This is not however the opinion of Barrois and Bury. According to these investigators $(8,16)$, the ciliated larva of Antedon rosacea is fixed by its anterior end (preoral pit), a kind of stalk, instead of being a dependence of the apical pole, seems to represent the preoral lobe.This remarkable contradiction between phylogeny and ontogeny is only apparent. I have already insisted on the fact that the orientation of adults has nothing to do with that of the larvae and that it is not logical to make a conclusion about one from the other. No account should be made from the phylogenetic point of view of the relative agreement of the embryos, following the expression of Carl Vogt. The preoral fixation of the larva does not say at all that the stalk itself is preoral. It is a secondary, adaptive phenomenon that is destined to facilitate true attachment recalling that of the primitive pelmatozoan. When the larva is thus attached to a foreign body, its organs try an analogous displacement to that which is produced in ascidians after fixation of the tadpole larva. The skeleton is designed, the stalk at the center of the apical pieces and the adhesive epithelial disc is transformed into a calcareous plate. The stalk of the young Antedon is quite apical in comparison to the developed animal, although the first point of fixation is preoral in comparison to the larva.

Asteroids. - In all the Astropecten of our coast and expecially in the small species, very quiet animals have a conical eminence that appears in the middle of the aboral surface. It is interesting to observe, especially in Astropecten spinulosus or squamatus, placed on a bottom of fine sand. The star promptly buries in the sand and nearly completely disappears. It leaves only the five ends of the arms (whose tube feet explore the water, as usual) and the turgid aboral eminence covered naturally with paxillae like the rest of the body. It appears to function as a tactile organ. In fact, if it is touched, it retracts and nearly completely disappears while the animal burrows deeper into the sand. This eminence is formed voluntarily and is nothing other than part of the aboral surface with a very thin integument covered with fine paxillae and swollen by coelomic fluid.

According to Sladen (173), the aboral cone projects conspicuously and is not retractile in the sub-family Porcellanasteridae. It forms an "elongate tubular prolongation" that could be as long as a radius. Perrier (142) has recently described an asteroid (two very young specimens from 3 to $5 \mathrm{~mm}$ ), Caulaster pedonculaus, that also has a relatively very raised and probably non-retractile projection. Perrier connects Caulaster to Ctenodiscus. Sladen believes however it is a young Porcellanaster.

Danielssen and Koren also have described a young individual (a single specimen, $\mathrm{R}=11 \mathrm{~mm}$ ) that they call Ilyaster mirabilis. It has a long extension on the aboral surface that is covered with paxillae that are very different from the rest of the disc and the arms. The extension seems to be mobile and is certainly not retractile.

Lyman (121) also found a dorsal cone in an ophiuroid collected by the Challenger, Ophiopyrgus Wyville-Thomsoni. It is a kind of conical projection from the middle of the dorsocentral plate. 
Perrier, A. Agassiz, Danielssen and Koren, Smon and Stürtz have compared these different conformations, until now specialized to the family of astropectinids (but which is lacking in some species) to the stalk of crinoids. They seem to think that asteroids go through a phase analogous to that of fixed crinoids and that this extension (greater in the young than in adults) is the last remains of the stalk separated from its point of attachment. Sladen and Carpenter have expressed doubts on this point of view and I am entirely of their opinion. Even if very young Astropectinida were attached, which is more than doubtful, this would be simply analogous with crinoids and not a trace of their phylogenic relation. Because we know with certainty that all stars and ophiuroids whose development has been followed have no such stage of attachment. For us, this aboral extension is probably a tactile extension, perhaps more developed in young than in adults, that has no morphological or physiological relation to the stalk of crinoids. We insist on this fact because presently several authors (Perrier, Semon, Neumayr, etc.) derive all types of echinoderms from types attached to the surface by a stalk. Naturally these appendages are for them indications of phylogenetic relations. We do not believe there is homology between these conformations and the peduncle of embryonic Leptychaster (Wyville-Thomson). This asteroid is viviparous and the young are attached to the integument of the mother by the aboral surface. This clearly shows it is a special adaptation. It is a fact that in the equally viviparous Asterias spirabilis the embryos (Perrier) are attached to the mother by an interradial and preoral peduncle.

\section{COELOM}

Study of the coelom, produced by the fusion of the enterocoelic vesicles, is of great importance for the morphology of echinoderms. We will study successively: $1^{\circ}$ its form and its subdivisions in different groups; $2^{\circ}$ its covering and its ciliated system, $3^{\circ}$ its contents, i.e. blood.

\section{SYNAPATIDS AND HOLOTHUROIDS}

The body cavity has various mesenteries, well described by Semper, Ludwig, Hérouard. that connect the intestinal circumvolutions to the body wall. The most important and most constant is the dorsal mesenary that runs along the upper part of the interradius $\mathrm{C} \mathrm{D}$, and encloses the genital canal. It is continuous with the lateral mesentery (interradiius D E) and a ventral mesentery (int. E A or A B). There is thus nearly half of the coelom that is not separated by any mesentery. Two well defined cavities are attached to the coelom, placed at the two ends of the digestive tube, perianal and the peripharyngeal space.

Perianal space. - It is very clear in sagittal sections of the lower end of the body (Cucumaria and especially Holothuria). It is lalcking in synaptids. Semper, Hérouard, etc.have reported it very briefly. It is a ring, completely closed, between the wall of the cloaca and that of the body, covered internally by the peritoneal epithelium. Its walls contain a strong layer of circular muscular fibers and form a sphincter. The perianal space has an important role in closing the cloacal opening. When its muscle fibers contract, the liquid it contains presses against the wall of the rectum and closes it. Often in animals killed very quickly, the perianal space protrudes slightly out of the animal in the form of a bag. 
Peripharyngeal space (Schlundsinus, asophageal sinus). - The peripharyngeal space likewise forms a ring around the pharynx from the buccal opening up to the water ring. It exists in all synaptids and holothuroids. It has been described by numerous authors, Selenka, Semper, Hamann, Théel, Semon, Ludwig and Hérouard. The last author gives an excellent figure of it (73).

In Synapta, when the water ring begins to extend the buccal tentacles, they are expanded and contain between them and the digestive tube a ring (peripharyngeal space). They are closed at the botton by a horizontal chamber attaching the water ring to the esophagus (Semon). Above, the tentacles leave a number or openings (10 to 12) between them as they diverge, by which the coelom communicates freely with the peri-esopharyngeal cavity (see pl. XXVIII, fig. 52). In the adult, this is crossed by a large number of small perpendicular septa to the wall (esophageal tract), often with ciliated urns. The septa are lacking above, so that there is a completely free circular space (peribuccal sinus of Hérouard). The septa are formed of connctive tissue filled with spongy corpuscles.

In holothuroids, the arrangements are not much different (see the excellent descriptions of Hérouard). The peripharungeal space in Cucumaria communicates with the coelom by five large interradial openings. Above, as in synaptids, there is a restricted peribuccal space.The esophageal tracts are formed of loose fundamental tissue with muscle fibers. In Cucumaria, a large number of migratory corpuscles are moved to the interior. In Holthuria, they are more solid and contain only a few amoebocytes.

In elasipods, Théel likewise described the peripharyngeal space and the esophageal tracts. All communication with the coelom is often interrupted by the presence of a continuous membrane connecting the water ring to the body wall (Elpidia glacialis, Benthodyte sanguinolenta, Latmogene, 180).

\section{CRINOIDS}

The arrangement of the various coelomic compartments is very complex. Having no new information, I shall content myself with repeating the summary of Perrier $\left(145,3^{\text {rd }}\right.$ series, v. 2 , p.67-68). It has been demonstrated (Perrier, Bury) that the chambered organ, with five chambers ooccuping the base of the calyx, is a dependency of the right enterocoel (Bury), divided by radial septa arranged around the axial organ (genital stolon of Perrier). Grovved extensions of this cavity enter into the cirri and the stalk, when one exists.

\section{ECHINOIDS}

The body cavity of echinoids is very large. In Gnathostomata, the intestinal circumvolutions and the gonads are connected to the body wall by perforated mesenteries, following the path of these organs. Moreover, a vertical lamina connects the axial gland and the stone canal to part of the esophagus and the other part to the apical pole. In regular urchins, the rectum is attached to the test by a very thich membrane that determines a sub-periproctal cavity. As in holothuroids, a completely closed perianal space surrounds the anus (reported by Prouho in Dorocidaris papillata). This makes two cavities superimposed around the rectum. Their wall contains circular 
muscle fibers whose contraction compresses the liquid in the cavity and consequently closes the lumen of the rectum.

In spatangoids, the mesenteries are more complicated and more solid because of the considerable weight of the intestine filled with sand. In addition to those just described in regular urchins, solid and nearly horizontal chambers connect the various circumvolutions. Vertical lamina (two oral and two aboral) attach the intestine to the two opposite regions of the test. The mesenterial lamina are so important in this group that a special skeleton is developed for their insertions. This is the case for the two lamina that border the apical pole (Spatangus) and the irregular plate located near the mouth in interradius A E. This plate, reported first by Hoffmann (15) and considered incorrectly by Agassiz as rudimentary auricles, exists only in spatanngina (Spatangus, Maretia, Eupatagus, Lovenia, Breynia, Echinocardium).

Peri-esophageal space of spatangoids. - All around the beginning of the digestive tube of Spatangus, under what are called lips, is found a completely closed peri-esophageal space notably described by Hoffman (1871) and Teuscher (1876). One part of its membrane connects to one part of the esophagus and the other to the periphery of the irregular pentagon of the water, lacunar and nerve rings. Sagittal sections show its arrangement very well (pl. SSVIII, fig. 54). This cavity is insinuated between the nerve ring and the water ring, thus simulating an annular space in the form of a schizocoel in asteroids and ophiuroids. The five radial schizocoel sinuses end in a cul-de-sac in contact with the peri-esophageal space without the two communicating. A small separating septum can be seen in sections. Moreover, the contents of the radial sinus and the periesophagealspace are completely different in sectioned samples. However Koehler (87) said that injections often pass from the sinus into the cavity and vice versa. My injections have never shown this. It is however a point that requires verification with fresh specimens because it is of great importance as we shall see later.

Peripharyngeal space in gnathostome urchins. - The labial cavity of spatangoids is very reduced in height in gnathostomids (regular urchins and clypeasteroids). In contrast, it is very developed and completely encloses the masticatory apparatus and its appendages and called the peripharyngeal cavity (pl. XXVIII, fig. 53).

Its limiting membrane (lantern membrane, Valentine) inserts below on the esophagus, just at the point where it leaves the masticatory apparatus. It is molded on the latter, notably on the soft parts of the teeth (dentary sacs), then goes up to cover the various masticatory muscles to attach circularly to the test at the level of the auricles. The cavity thus limited is crossed by numerous organs (all the radial organs) and is subdivided by the secondary chambers without importance. It iss perfectly closed and does not communicate either with the exterior or the coelome. This can easily be proven by inflation or injection with a dye.

The peripharyngeal cavity has various appendages that it is convenient to examine in detail. These are $1^{\circ}$ external gills, $2^{\circ}$ Stewart's organs.

External gills. - On the oral surface of a Strongylocentrotus are 10 tufts arranged in pairs at the edge of the bouccal membrane and the coronal plates, one in each interradius. Theres are the external gills, placed in indentations of the test. This makes it possible to confirm their presence in dry samples and fossils. As Prouho remarked, these gills communicate only with the peripharyngeal cavity and not at all with the coelom as is generally believed (Hamann). Their histological makeup is very simple.The very thin and simply connective tissue walls are covered on both sides with a ciliated ectoderm with small cuboid cells. The internal epithelium is strongly ciliated (especially at the point where the gills open into each peripharyngeal chamber in a way to determine the active currents of the fluid). 
The external gills are very developed in echinothuroids (Ludwig recognized them in Asthenosoma varium Grube, Agassiz in various Asthenosoma and Phormosoma, the cousins Sarasin in Asthenosoma urens) and most of the regular urchins (echinids, diadematids, arbaciids, echinometrids). It has been proven, contrary to the ideas of Müller, that the gills are present in salenids (Acrosalenia, Peltastes, Salenia). Stuart (1877), Agassiz (1880) and especially Duncan and Sladen (1887) described them both in extant species and in fossils whose peristome had the characteristic indentations. There were probably gills also in the Paleozoic Archoeocidaris, as shown by the presence of interstices between the actinal plates and the primary interambulacrals (A. Agassiz). In contrast, external gills are completely lacking in cidaroids and clypeasteroids.

Stewart's organs. - This name, proposed in 1888 by Prouho (151), refers to internal diverticula of the peripharyngeal cavity discovered in 1871 by Stewart (174). On the five radial angles of the internal surface of the matiscatory apparatus of Dorocidaris are arched voluminous appendages that project into the perivisceral cavity (see figures of Stewart and Proho, 151, pl. 19, fig.1). It is easy to demonstrate by sections and injections that these organs are diverticula of the peripharyngeal cavity. The very thin wall is ciliated on both surface and contains numerous spicules that are lacking in the small secondary mamelons of the convex surface.

Stewart's organs seem to be present in all cidaroids. Ludwig recognized them in all that he studied (Cidaris tribuloides and metularia Blainv., Goniocidaris canaliculata Agassiz). Small supplementary caeca are found at their base (105). Ludwig also reported them, in a rudimentary state in Diadema setosum Gray. The cousins Sarasin found them in a high state of development in Asthenosoma urens. They are enormous smooth vesicles located in the five radial angles of the masticatory apparatus and fill a large part of the coelom of this echinothurid (159, tabl. XIV, fig.21). Judgment should be reserved for the rudiments they reported in Toxopneustes pileolus Agassiz. I have found Stewart's organs, very different from those just discussed, in the clypeateroids Echinodiscus biforis and Peronella orgicularis (pl. XXIV, fig. 10). They are extremely delicate vesicles on the interior surface of the masticatory apparatus, one pair in each interradial segment. But as the digestive tube is attached to masticatory apparatus, it prevents the development of several of these organs so that instead of ten, there are only eight or nine of them. Sections and injections clearly show that these vesicles are diverticula of the peripharyngeal membrane. Their very thin wall is formed of two joined epithelia without a discernable interposed connective tissue zone. I have not found Stewart's organs in Echiocyamus pusilllus, although I examined them with care by dissection and sections. Perhaps Agassiz recognized them in various clypleasteroids. He said, in fact (2, p. 689) that the membrane of the masticatory apparatus "is in the Clypesteroids reduced to the small bursiform appendage of the inner part of the pyramid." Except for this phrase, he said nothing about it and did not show it in any of his figures.

Functions of the external gills and Stewart's organs. - The gills evidently serve for respiration of the peripharyngeal liquid that bathes many important organs (nerve centers, masticatory muscles, teeth, etc.).

In cidaroids and clypeasteroids, which lack external gills, it seems logical, as Prouho proposed for Dorocidaris (151), that Stewart's organs replaces them functionally and that the peripharyngeal liquid can no longer take oxygen from the surrounding medium but takes it into the liquid cavity by these vesicles.The thinness of the walls makes them very appropriate for this function. It is not doubted that the gas exchange can operate in this way but it is to be noted that diffusion seems to operate over the entire surface of the peripharyngeal membrane. This is, in fact, very thin and presents a very considerable expanse so that, from the respiratory point of view, the Stewart's organs appear to be truly superfluous. 
This is evidently not the sole function of the Stewart's organs. They are found in Diadema setosum that has external gills. They reach a considerable size in Asthenosoma urens, which also has well developed gills. This led the Sarasins to propose another theory (159). In Asthenosoma, with a flexible test as is known, the vesicles are strictly confined to the length of the ambulacral area, forming thus a kind of elastic cushion that supports the wall. The Sarasins suppose the vesicles function to prevent the collapse of the dorsal wall, especially when the weight of the mature gonads could depress it. This explanation seems to be very extraordinary, but as I have not had the good fortune to study echinothurids, I shall abstain from other comments about it. Jeffreys Bell (14) noted that in another echinothurid, Phormosoma placenta, Stewart's organs are absent or rudimentary. They also appear missing in Ph. bursarium and tenue, which does not support the theory of the Sarasins.

We lack much information on the presence of Steward's organs in types with or without external gills to make a very firm opinion. For my part, I believe the external gills and Stewart's organs, as well as the tentacle sacs of the regulars, in addition to their respiratory functions that I consider very insignificant, play an important role in the equilibrium of internal fluids of the urchins, similar to that Hérouard has so well defined for the respiratory trees of holothuroids (73). But I return to the study of this question in a later work.

Importance of the peripharyngeal space. - It is very probable that the peripharyngeal chamber of gnathostomes is exactly homologous to the peri-esopohageal cavity of spatangoids. In fact, these two cavities have exactly the same relations except that the former is considerably dilated to accommodate the masticatory apparatus. They enclose the oral nerve ring, the five radial schizocoeloic sinuses end in caeca against their wall without communicating with them, and finally the water and lacunar rings both lie on their membrane and consequently outside these cavities.

In the preceding chapter, I consider the peri-esophageal space as part of the coelom, of enterocoelic origin. But because I have never followed its development, this point of view is only a hypothesis. It should be noted that in echinoids, the schizocoelic space present in synaptids, asteroids and ophiuroids, which we shall later study under the name of oral sinus, is not found below the nerve ring. It can be asked if a part at the very least of the cavities that we just described do not represent this very developed oral sinus. Teuscher and Hamann, have in fact attributed this importance to the peri-esophageal space in spatangoids. In the absence of developmental observations, I content myself with asking the question without trying to resolve it.

\section{OPHIIUROIDS}

In the disc, the coelom is very reduced because of the presence of the digestive tube and respiratory sacs. It extends the length of the arms, particallly divided by the cross walls.

Disc. - In the disc, other than the small digestive sac, there are one or two circular chambers attaching the esophagus to the peribuccal pieces (pl. XXV, fig. 29). The strongest is inserted ono one part above the nerve ring, on the other hand on the esophagus at the point were it is curved to form the digestive sac. It is composed of connectiave tissue with circular muscle fibers.. Both surfaces are covered with the enterocoelic epithelium. The space it encloses around the esophagus (oral space of Koehler, 88, inner Perihamalraum of Ludwig, 107) can be easily demonstrated by injections. It is completely closed. 
The second chamber, thinner than the first, is inserted on one hand nearly at the level of the water ring and on the other hand to the wall of the digestive sac. It does not contain muscle fibers. Hamann made a singular error about this. He believed the water ring opened into this space (791, pl. 23, fig. 21 and 22). This would be quite extraordinary from the morphological point of view. It is easily seen in section (pl. XXV, fig. 29) that the water ring is completely separated from the two oral spaces and there is no communication between them.

The two chambers are present in Ophiothrix fragilis, Ophiocoma scolopendrina and Ophioglypha albida. Most often there is only one in Amphiura squamata and Ophiactis virens. The chambers evidently function to maintain the separation between the body wall and the digestive tube. The oral spaces form elastic cushions that probably play an important role in the closure of the buccal opening (it basically has the same mechanimal arrangement as the perianal spaces of holothuroids and regular urchins.

Arms. - At the beginning of formation of the arms (Amphiuira squamata), they are obviously complete as in the larvae of Antedon rosacea (Perrier). There is no trace of the enterocoel (pl. $\mathrm{XXV}$, fig. 26). It is only later that this is extended in the form of a cellular tube. As development continues, the tube grows laterally until it touches the edge of the radial nerve band. If development continues in this direction, we will have an asteroid arm, with its large coelomic cavity, between the vertebral axi, the sides and the base of the arm. But in ophiuroids, another processs intervenes. A transverse calcareous chamber is formed connecting the axis (formed by the discoid ossiclesl) to the outer wall of the arms. The coelom is thus divided into a series of small chambers (see 29, figures 6, 7 and 8) that connect all the lower part of the arms (dorsal canal in the literature). I reiterate that in each of the lateral spaces the radial schizocoel communicates with the enterocoel by an orifice, recently unrecognized by Hamann.

\section{ASTEROIDS}

The mesenteries do not form any interesting chambers. There is no peri-esophageal space. Each radial cecum of the digestive tube is attached to the aboral wall of the arm by two mesenteric chambers, forming a kind of canal that extends the entire length of the cecum. (See the diagram of Ludwig, 98, plate 8, fig. 38.)

HOMOLOGIES. — There is a peripharyngeal space in synaptids, holothuroids, echinoids and ophiuroids, but it is important to note that these various formations are only analogous. Their origins are very different. In the first two classes, they are processes from the oral water ring and develop in parallel with the pharynx. They make between them and their walls a circular space that usually remains in communication with the rest of the coelom.

It is quite probable that the peripharyngeal cavity of gnathostome urchins are derived in the same ancestral formation as the peri-esophageal space of spantangids, as we have said above. It is certain that this space has a very different origin than that of holothuroids. These two formations thus cannot be considered as really homologous. ${ }^{12}$

\footnotetext{
12 I do not see why Hérouard, in the conclusions of his work (73, page 695) says that "the peripharyngeal sinus (of holothuroids) does not correspond to the peripharyngeal space of Dorocidaris, but to the lacunae sunken into its pharyngeal ridge." The peripharyngeal sinus of holothuroids is certain of enterocoelic origin, while the pharyngeal lacunae of urchins are schizocoelic and formed from the lacunar system. There is thus no correspondence between these two formations.
} 
As for the oral spaces of ophiuroids, they are chambers certainly located below the nerve and water rings. As a consequence they have no resemblance to the peripharyngeal cavities of urchins and holothuroids.

\section{COVERING AND CILIARY ORGANS OF THE COELOM}

In all echinoderms, the enterocoelic cavities are covered with a continuous ciliated epithelium forming a mosaic after treatment with silver salts. The contents of the coelom are circulated by the cilia of the peritoneal covering and often also by special ciliated systems either fixed or free in the liquid cavity. We are going to consider them successively in the different groups.

\section{SYNAPTIDS}

CILIATED URNS (WIMPERTRICHTER, WIMPERORGANE). - The ciliated urns of synaptids, discovered by Mertens (1835) in the mesentery of a Chridota, have been studied by Grube (1851), J. Müller and Leydig (1852), Berlin (1853), Semper (1868), Semon (1887) etc. But their functions and their histology are still very unclear.

They are small ciliated funnels of variable forms (pantoufles of Leydig, 99), sometimes grouped in packes, inserted by their base onto the mesentery and hanging free in the coelom. They are present in all species studied of the genera Synapta, Chiridota and Anapta. Danielssen and Koren (36) reported them also in the related types, Myriotrochus Rinkii and Acanthotrochus mirabilis. Actually, their figures are not very definitive. In summary, they are well defined only in the synaptids.

There are arranged in a fashion constant for each species. In several Chiridota, Synapta similis and Beselii Semper, the funnels are accumulated in large numbers in interradius AB of the trivium all along the mesentery of this interradius (Semper). Semon said that there are many of them to the right and left of the dorsal mesentery Synapta digitata. For my part, I have always found them in large numbers in Synapta inharens in interradius DE. They are many in the peripharyngeal space. They are very scattered or missing completely in the other interradii. A small, slightly proecting fold passes between the urns (pl. XXIV, fig.11) at the base of which are inserted some funnels. I am completely ignorant of the reason it occurs.

In Synapta, the funnels are general isolated or in small number on the same peduncle. In Chiridota and some synaptids ( $S$. Kefersteiinii Selenka), they are in contrasted assembled in a mass on the same stalk to form tufts (Wimpertrichterbaümchen), well illustrated by Semper (168, pls. VI and VIII).

Histology. - I have studied the urns of living Synapta inhorens and fixed in Flemming's liquid. I have in addition clarified and extended the results obtained by Semon on Synapta digitata. The form is very variable. Sometimes they are a largely open urn, sometimes with a funnel with shortened walls and more or less deep with a height of 300 to 400 ų.

The urns are attached to the wall of the coelom by a short connective tissue peduncle. The entire external surface is covered with a thin connective tissue layer and the parietal epithelium (pl. XXIV, fig. 11). The internal surface has a ciliated epithelium formed of tall filiform cells, 
tightly packed against each other and with long cilia that pass across the pores of the cuticle (pl. XXIV, fig. 12). This epithelium is basically identical to all ciliated organs (stone canal, ciliated organ of ascidians, etc.). They are a little recurved on the external surface.

I have found only once a funnel in the process of developing (pl. XXIV, fig. 11). The ciliated epithelium was well differentiated only in the bottom of the shallow cup. However, this funnel was already active despite its small size.

Contents. - The urns always have a very large plalsmodium (pseudo-plasmodium) formed of corpuscles like those of the liquid of the coelom. These plasmodia that swirl in the center is kept a distance from the wall by the action of the cilia. The cells that compose it are identical to those that are free in the coelom.

Functions. - The ideas of J. Müller and Leydig, which make the ciliarted urns the termination of the blood vessels or tube feet and considered them consequently as excretory organs, are now completely abandoned. However, the cousins Sarasin have recently revived them $(159,1888)$ without providing new arguments to support this point of view and repeating the error of Leydig. Semper (168) thought they serve perhaps to determine the currents in the coelomic fluid. Semon (164) gave a completely different hypothesis. According to him, the numerous cells emigrate to cross the stalk of the ciliated funnels, which would make up consequently organs that attract coelomic amoebocytes to facilitate their passage into the skin. "Wir hátten uns doch danach die Wimpertrichter als Organe vorzustellen, die dazu bestimmtsind, die lymphoiden Zellen der Leibshöhle aufzunehmen und eine Anfangsstation für ihre Wanderungen in die Gewebe zu bilden. Es wären grosse und complicirt gebaute Lymphstomata der Leibesehöhle.” (p. 420).

For my part, I cannot accept the opinion of Semon. There are no more migratory cells in the stalk of the funnels than elsewhere. This can be confirmed with living specimens. They can sometimes be found coming from the skin and not from the coelom because the cilia hold at a distance the plasmodium attracted by the funnel. It is very difficult for the cells to come into contact with the skin. Diapedesis can occur at most other points more easily than in the funnels. As Sember supposed, it is quite probable that they serve to produce an active current in the coelomic fluid, making up for the inadequacty of the cilia of the peritoneal covering. Their constant position along a mesentery supports this opinion. When urns are observed in living specimens, one sees that all the corpuscles that pass near the opening are actively pulled into the interior of the funnel, the cilia producing an incurrentt cone in the zone of attraction from which the cells are quickly mixed. In my opinion, and Semper also makes this connection ${ }^{13}$, the ciliated funnels of synaptids are completely homologous to the urns found in Sipunculus and to the ciliated cups that I have described in various Phascolosoma (329); Like the synaptids, these sipunculids are found nearly immobile buried in sand. Their body fluid is relatiavely great. It is thus not surprising to encounter these organs either free (sipunculids) or fixed (synaptids) to put it in motion. It should be noted however that the urns of Sipunculus nudus are first fixed to the wall of the lymph gland (dorsal vessel in the literature) that runs the length of the esophagus (Ray Lancaster, Cuénot). In their young state, they are thus absolutely comparable to the ciliated organs of synaptids.

It is very possible that the energetic mixing of the ameobocytes facilities their disintegration and the subsequent phagocytosis of the dead cells, but I do not have sufficient observations to make a conclusion.

Enigmatic formations. - In Synapta inhorens, I have encountered formations on the wall of the coelom whose function escapes me completely. I shall only describe them.

\footnotetext{
${ }^{13}$ Die Stimmesverwandtschaft der Wirbelthiere und Wirbellosen, Arbeiten aus dem Zool. Zootom. Inst. In Warzburg, 1. 2, 1875 (see p.61).
} 
When we examine vertical sections of the upper part of the body, we seen in places the peritoneal covering has an unusual lappearance (pl. XXIV, fig. 13). It seems to cover small rounded mamelons, arranged side by side in large numbers, nearly sessile on the wall. They are filled with fibrillar connective tissue arranged radially around a central nodule. All of it is covered with a plate epithelium, exacatly like that of the peritoneum. These mamelons appear to be forming continuously, at least all stages of development are seen, from a slight protrusion of the wall up to a more or less accentuated pyriform aspect. These enigmatic formations are always encounted in large number ony on the upper prt of the coelom near the origin of the radial muscles and in the culs-de-sac between the internal portions of the tentacles. I have not seen them in other parts. Nothing indicates these formations are glandular or sensory. Are they ciliary organs? It is necessary to study the living animal, which I have not been able to do.

\section{HOLOTHUROIDS}

Ciliary organs are not known in holothuroids. Circulation of the coelomic fluid appears to be active around the respiratory trees.

1

\section{CRINOIDS}

CILIATED CUPS (WIMPERSÄCHEN). - The ciliated cups, discovered by Ludwig in various Antedon (1877), are modifications of the coelomic epithelium of the arms. They are only in the lower cavity (called dorsal). They are very abundant in the pinnules where they touch each other. They are found in the figures in the memoir of Perrier (145). Hamann has represented those of Antedon rosacea perfectly (71).

They seem to be present in most crinoids. That have been reported in various species of Antedon, Actinometra, Hyocrinus and Pentacrinus.

They are small hemispherical culs-de-sac, bounded by connective tissue and lined with an epithelium whose cells are taller toward the end, with a long cilium. In Antedon rosacea and Eschritii, Pentracrinus Wyville-Thomsoni, the base of the cup has flat non-cilary cells (Hamann) that Ludwig, probably in error, showed as large cells. The cups are very near the axial nerve cord but I have never seen nerve fibers ending there.

The cups appear very early in the pentacrinoid larva (Perrier). The cells of the coelomic epithelium become larger in places and form cups sunken into the connective tissue of the arms. For all authors, these ciliated cups function to circulate the fluid in the cavity of the pinnules. Ludwig considered them homologous to the ciliated urns of synaptids, which is completely our opinion (from the physiological point of view, of course).

\section{ECHINOIDS}

Because of the large volume of the coelom, we should expect to find special ciliary organelles, because it is evident that the action of peritoneal cilia cannot efficiently circulate the entire mass 
of coelomic fluid. These organelles are represented by globules with a long flagellum floating in large number in the midst of the blood cells. They very much resesmble spermatozoa. The head is formed by the nucleus and a thin protoplasmic layer to which is attached a long, thin flagellum. If a drop of coelomic fluid is examined microscopically, one always sees a more or less large number of the ciliary globules moving the surrounding ameobocyes with their flagellum. Refer to my work on the blood of invertebrates for more details (illustrated by Prouho, 151, pl. XIX, fig. 12; 32, pl. XVIII, fig. 14).

According to Prouho (151), these globules in Dorocidaris papillata are formed in a spongy tissue covering the surface of the madreporite cavity. I have not been able to verify this in the various urchins I have studied.

\section{OPHIUROIDS}

The general cavity and the enterocoelic cavities of the arms are lined with a ciliated epithelium formed of flat cells. This epithelium is strongly modified in the lower part of the canal (called dorsal canal). This part of the coelom has its upper half covered with the usual flat epithelium while that of the lower half has a tall epithelium that is strongly ciliated. Hamann described and illustrated it perfectly in Ophioglypha albida (7). I have found this arrangement in all the ophiuroids I have studied, with maximum development in Ophiactis virens and Amphiura squamata and a minimum in Astrophyton clavatum. This epithelium is exactly like that of the ciliated cups of crinoids and Hamann has not failed to make the comparison. It is evident that this ciliated region that extends the length of the arm to the disc produces an active current, whose direction of the current has not been determined, and probably also to facilitate exchange between the coelom of the arms and the radial schizocoel by openings at the level of each ambulacral ossicle (wrongly denied by Hamann).

This ciliated epithelium differentiates very early in embryos of Amphiura squamata.

\section{ASTEROIDS}

Asteroids do not appear to have special ciliated structures. The currents of the coelomic fluid appear to be particularly active in the interior of the papullae and at the level of the openings between the radial schizocoelic sinus and the general cavity of the arms.

\section{BLOOD}

In a preceding work, I studied completely the blood of echinoderms (32). I shall add only some complementary details and take up the question.

The contents of the coelom, the water vascular system and the lacunar system are in general identical as far as the elements they contain (except in some types of red cells that are located either in the coelom or in the water vascular system). They differ only in the amount of dissolved 
albuminoids. There is always a great deal of this in the lacunar system. The fluid it contains is sometimes slightly colored (Krukenberg in holothuroids).

In asteroids and ophiuroids, the amoebocytes, which all look alike, contain a quantity of small yellow, very refrigent grains that I have called albuminogenic granules. As they age, the granules decrease in number. The protoplasm decreases so much that at the end there is only the nucleus that doubtlessly dissolves in turn in the surrounding fluid.

Iin all other echinoderms (echinoids, crinoids and holothuroids), the amoebocoytes are simple amoeboid cells filled with various reserve products, fat (echinochrome in echinoids) or protein. In this form of reserve amoebocytes, they pass into the tissues (migratory cells, Wanderzellen) and doubtless provide for their nutrition.Carl Vogt and Yung incorectly considered the migratory cells of holothuroids (Cucumariai) as parasitic productions.

Synapta inhorens. - The blood corpuscles of this synaptid that I have not studied in my work on blood, are very like those of urchins. The normal amoebocytes, as they leave the producing glands, are very amoeboid cells with clear protoplasm, very often with waste granules, strongly stained with safranin and methyl green (pl. XXIV, fig.15, $c$ and $d$ ). But these amoebocytes are for the most part filled with reserve material, consisting of either small colorless granules (fig. 15, $a$ ) or of mahogany red granules that become black in osmic acid (b) that I reported as a fatty substance, echinochrome, very frequent in urchins. These modified amoebocytes go into all the tissues where they are easily recognized in living specimens. A large number of parasitic organisms are found in the coelom. Brown bodies (Leydig and Berlin) surround gregarines that I illustrated under the name of Syncystis synapta (Revue Biologique du Nord, $1^{\text {st }}$ May 1891) (we also sometimes find them in the lacunar system). An infusoirian of the urcelarians, Trichodina synapta, etc.

Red blood cells. In some echinoderms, we find red blood cells with hemoglobin that have exceptional characteristics. In Ophiactis virens, these red blood cells that Fættinger (50) discovered are found only in the water vascular system. They are small flat discs that lack nuclei like the red cells of mammals. In Cucumaria Planci, Thyone gemmata Pourt. (Howell) and Thyone aurantiaca (Cuénot), the red blood cells are often irregular in form with small, thin pseudopods and a small nucleus. They are always found in the coelom and in more or less considerable quantities in the water vascular fluid. In all species, the stroma of red blood cells is filled with hemoglobin.

This hemoglobin, with characteristic specral bands, is very different from a chemical point of view from the hemoglobin of mammals. This led Kruckenberg and Preyer to deny they had a respiratory role. Preyer (150) noted that turacine and helicorubine have exactly the same spectrum as hemoglobin. From this he concluded that the existence of the latter has not been demonstrated for echinoderms. For Ophiactis virens, at least, it is definite that these red blood cells are respiratory red cells like those of mammals. The anatomical distribution of the water vascular system, that replaces the missing respiratory sacs, leaves no doubt in this regard. It is probably the same for the holothuroids. However, the red blood cells have great individual quantitative variation that it would be useless to try to give a physiological demonstration of their role in the uptake of oxygen.

I have represented (pl. XXIX, fig 60) the enucleated red blood cells of Ophiactis virens. Illustrations of the red blood cells of holothuroids are found in my work on blood (32, pl. 8, figs. 17 and 18).

Lymph glands. - The lymph glands or plastidogens, according to the term proposed by Perrier, are very numerous in echinoderms. With the exception of the Tiedemann bodies (asteroids) and 
Polian vesicles (asteroids, ophiuroids, holothuroids and synaptids), they open into the water ring. They are connected to the lacunar system. We shall descripe them in the chapters related to these two circulatory systems.

\section{DIGESTIVE TUBE}

I do not intend to describe the path of he digestive tube in each family. It is known in minute detail. I shall only describe the morphological relationships and especially the ancestral form in each group.

Holothuroids and synaptids. - In holothuroids, comprised of molpadids, elasipods and synaptids (Myriotrochus, Chiridota, Acanthotrochus, etc.), the intestine runs from the mouth to the anus directly opposite the mouth (I say nothing about the secondary adaptations in Rhopalodina etc.). The animal being placed vertically with the mouth above, if the digestive tube is placed on the horizon plane, we see that it forms a clockwise spiral crossing successively radii D, E, A and $\mathrm{B}$ to end at the anus. It is connected to the body walls by various mesenteries that we have reported. When the digestive tube is straight, as in some Synapta, it forms a very elongated single spiral although the various mesenteries show it has conserved their place. An important character to note is that the anus of the adult is nothing other than the blastopore of the larva.

Crinoids. - With the same arrangement, the disc of Antedon, Rhizocrinius, Bathycrinus, Pentacrinus etc. in a horizontal plane, the digestive tube leaves from the central mouth and makes a complete clockwise spiral.But instead of opening at the aboral pole, it opens on the oral surface in the middle of interradius CD as Bury (16) has emphasized. But there is a great difference compared to holothuroids. The larval anus or blastopore is closed and the anus of the adult is a secondary formation. Perhaps the closing of the blastopore occurred in the pelmatozoan ancestor because of the development of calcareous pieces. The rectum can no longer open on the aboral pole, filled by the calyx and the stalk, has moved upward towards the oral surface and always rests in the holothuroid plane (radius A, interradius CD) and opens in interradius CD at a point very far from the aboral pole. This is the case in cystids, crinoids and blastoids.

H. Carpener (21) has shown that the intestine of Actinometra makes up to four complete spirals from the mouth to the anus (see his figure, p. 92).

Echinoids. - It is probable that the digestive tube of all urchins is first like that of young Hemiaser cavernosus described by Lovén (118). The intestine is straight, swollen in the middle. It ends at the center of the oral surface, the other part under the apical system. In this specimen (diameter $=2.3 \mathrm{~mm}$ ), both ends are closed.

In another young of the same species ( $D=2$ to $3 \mathrm{~mm}$ ) described by Agassiz (3), there is a little more advanced stage. The mouth is still in the center of the oral surface. The intestine ends at the aboral surface at a point we shall soon describe, making a complete clockwise spiral. This trajectory, completely like that of holothuroids and crinoids, should certainly be found in all young urchins. It is fixed in the adult state in clypeasteroids, where the anus instead of being near the aboral pole is more or less moved to the oral surface. In fact, in the clylpeasteroids I have examined (Echinocyamus, Echinodiscus, Perionella) and Clypeaster subdepressus (according to the figure of Agassiz, 2), the digestive tube, leaving the masticatory apparatus, crosses radii E, A, is curved to cross radii $\mathrm{B}$ and $\mathrm{C}$ and a little before reaching radius $\mathrm{D}$ is curved again to the anus in interradius AB (pl. XXIV, fig.16). We see that it makes a single spiral. 
In regulars and spatangoids, because of the elongation of the intestine, the primitive arrangement is hidden. When the intestine reaches the end of the first spiral, nearly in interradius $\mathrm{CD}$, it recurves upon itself and makes a second spiral in the inverse direction to open in the anus placed either at the apical pole (regulars) or at a point in interradius AB (spatangoids).

As in crinoids, the larval anus is closed and the anus of the adult is a new formation without any relation to the blastopore. All urchins certainly derive from types with an apical anus located opposite the mouth. In fact, as is proven by the investigationns of Lovén, Agassiz etc., all young clypeasteroids and spatangoids pass through this stage that is fixed in regulars. The anus, first at the apical pole, descends little by little towards the oral surface, always in interradius AB. Thanks to paleontology, it is possible to establish the entire series of intermediary forms like that followed in ontogeny. Among the cypeasteroids, Pygaster still has the anus close by the apical system. Spatangoids and a large number of cassiduloids have this character.

It is very difficult to explain, especially because of the lack of information on development, the displacement of the anus in regulars. In young Strongylocentrotus, Lovén has shown that the anus opens between the dorso-central plate and terminal B, where we find it in adult Salenia and Heterosalenia, maintaining the ancestral location and also in all Mesozoic and extant echinoids, although the periproctal space is filled with small plates. It seems most probable that this is the place, in the echinoid plane (radius B, interadius DE), that the anus is found in the ancesters of regular urchins. The exactly central anus in adult Palaechinus, cidaroids, arbacioids, echinothuroids, diadematoids (Aspidodiadema, Micropyga etc.) could quite possibly have been primitively excentric and then is central because of the development of small periproctal plates. But how to explain the present case in Acrosalenia, Pseudosalenia, Peltastes, Goniophorus, various Cretaceous diadematids (Pseudodiadema, Cyphosoma, Echinocyphus), in which the anus is no longer in the echinoid plane but in the plane of Lovén (radius D, interradius $A B$ ) more or less sunken into the basal B (the genital pore corresponding to it having disappeared in various Acrosalenia?

All irregulars certainly descended from forms with the anus in the plane of Lovén, located near the calyx (stage shown in all small individuals, fixed in Hyboclypus and Galeropygus in spatangoids). It is not possible to say with certainty that this is the ancestral form, the anus being endocyclic, as in Acrosalenia, or exocyclic in contact with the external edge of the calyx. The fact is that in small individuals, the first appearance of the anus is exocyclic near the basal AB. But this could easily be due to an acceleration of development. In fact, in echinoconids (Pygaster), Lovén showed that the calyx was open so to say, as if the anus became free of its limits to be placed in interradius AB. In small Hemiaster cavernosus (shown in 118), the digestive tube ends in a caecum exactly below the apical center. It then is displaced a little to open outside the calyx. It is thus quite possible that all the irregulars descend from endocyclic forms. In the course of development the anus descends more or less on the aboral surface and can even pass to the oral surface.

Ophiuroids and asteroids. - The primitive form is that of a more or less large sac, whose volume is related to that of the disc (pl. XXV, fig. 25). As in crinoids and echinoids, the larval anus closes. The digestive sac remains closed in ophiuroids and some asteroids (astropectinids). But in the others, an anus is secondarily produced on the aboral surface in interradius BC.

The digestive tube in the form of a closed sac persists in ophiuroids as is known. It is only transitory in asteroids. In fact the digestive tube of asteroids develops various appendages on the aboral surface of the sac (stomach caeca, lacking in Luidia). The others go into the arms (radial caeca, lacking in Hymenodiscus). 
The development of these appendages and the trace of the anal opening in Astropecten is in my work on asteroids (28).

$\S$. In summary, the blastopore does not become the anus in adults except in synaptids and holothuroids. In all other classes, it is obliterated at some point during development and during a more of less length of time the digestive tube terminates in a cecum at its aboral end. This state is fixed in ophiuroids and astropectinids. The secondary anus opens independently in various groups as shown by the different positions it has: in interraduis $\mathrm{CD}$ in cystids and crinoids, near radius $\mathrm{B}$ or in interradius $\mathrm{AB}$ in urchins, in interradius $\mathrm{BC}$ asteroids.

At the same time the digestive tube extends the length of the body, it always spirals in a clockwise direction. The spiral is simple in synaptids, holothuroids, crinoids (Actinometra has a secondary complication) and clypeasteroids (regulars and spatangoids have a secondary complication).

Appendages of the digestive tube. - The digestive tube is often complicated because of the addition of appendages that either have a special role or to increase the secretory suface.

The rectum of synaptids and holothuroids is enlarged into an enlarged cecum that is connected to the body wall by muscular attachments. The respiratory trees open into the cloaca. The tubes of Cuvier are there. In some elasipods, Elpidia glacialis and others, the rectum has at its end a large lateral pouch that Théel inaccurately called a cloaca (179) and that appears to function as a reservoir for feces. In the specimen I have studied, it was filled with mud like the rest of the intestine.

In Antedon, the intestine has more or less complicated enlargements in its path that have been called the stomach, hepatic diverticula etc. that do not vary much from the general form. The projecting anal tube can be called a special differentiation. It is muscular and perhaps is a respiratory organ.

Echinoids can be divided into two sections in regard to the masticatory apparatus. One is peripharyngeal spaceta (regulars and clypeasteroids) and Atelostomata (spatangoids). It is probable these two groups were separated before the formation of this apparatus. However many authors, Agassiz, among others, thinks the masticatory apparatus was once present in Atelostomata (cassiduloids) but atrophied. That is not my opinion. Development would solve the question because, if the hypothesis is true, it is impossible that rudiments of the apparatus in question would not be found in young animals. The very complicated structure of the teeth has been studied by Valentin, Hoffmann and especially Giesbrecht (60). In spatangoids, the digestive tube, nearly at the place it crosses interradius DE, has a diverticulum. This is a large sac into which food does not enter, with abundant capillary lacunae. It probably has an important role in digestion. It secretes a deep brown liquid that fills the cavity (Koehler) that has not been studied physiologically. The rectum of Echinocardium flavescens and Schizaster (Koehler) has a small diverticulum that seems to be a reservoir for feces like the rectal diverticulum in Elpidia glacialis. Finally, the intestinal siphon (missing in Dorocidaris) must be mentioned. It is probably a respiratory organ (Perrier). Koehler described a second siphon in Schizaster, Brissus, and Brissopsis (confirmed by Hamann).

In ophiuroids, the digestive tube is a simple sac without any kind of appendage. What are often called interradial hepatic appendages are nothing other than portions of the sac that are insinuated between the gonads and respiratory sacs. They show no special differentiation and have no regularity.

In asteroids, the digestive tube has some glandular appendages covered with a very active digestive epithelium, the radial caeca, two in each arm, and the stomach caeca (Blinddarmchen, 
cæcums interradial or rectal) that open at the top of the stomch sac. They are missing in Luidia. Finally, the esophagus of echinasterids has ten very folded and glandular diverticula that I have called esophageal pouches (28).

Histology. - Digestive cells, mixed in large number with supporting muscle cells, have characteristics that are very constant in echinoderms. These are tall cells with protoplasm filled with granules nearly always brown or yellow. They are illustrated in many monographs, Jourdan (86), Hamann $(67,68,69)$, Cuénot $(28,29)$, etc.

There are never differentiated glands. It is always a simple cellular layer. However, Koehler has described true glands in the esophagus of spatangoids, but this requires confirmation. I do not know of any author who has seen them since. Kohler.

Finally, the digestive tube is richly enervated, especially in the esophageal region, with packets of nerve fibers coming from the oral ring and located either between the epithelial cells (asteroids, urchins, gnathostomids, crinoids) or in the connective tissue wall of the intestine (ophiuroids, spatangoids, holothuroids and synaptids.

Regarding the action of digestive enzymes, comparable to trypsin of higher animals, consult the works of Krukenberg and Frederiq ${ }^{14}$. MacMunn has made observations on the pigments of the intestine (enterochlorophyl, etc. ${ }^{15}$ ).

Nutrition. - The food of echinoderms is extremely variable and nothing is more curious than to compare the different processes used by these animals to ingest their prey and obtain nutritive particles.

Synaptids, elasipods and aspidochirotes swallow the sand or mud in which they are buried. The buccal tube feet more or less aid ingestion. Synapta, as is known, has the digestive tube filled with sand. According to Danielssen and Koren, that of Acanthotrochus is filled with biloculines and mud. I have found the entire digestive tube of Elpidia glacialis, from the mouth to the anus, filled with fine mud with globigerimans, diatoms and radiolarians (also reported by Théel, 179). It is the same for Kolga hyalina (Danielssen and Koren, 36). The intestine of Holothuria impatiens (from Naples) contains sand very rich in diatoms.

It is known that the buccal tentacles of dendrochirotes collect food. They capture all particles floating in the water (diatoms, protozoans, larvae, etc.) and from time to time they are inserted into the esophagus to remove them.

It is now proven that holothuroids that live on madrepore reefs do not feed on the polyps as is often said, but absorb only the fine mud accumulated in the crevices (Kent, Grenfell, Guppy, etc.).

In crinoids, the food is captured by ciliated currents of the rows of ube feet and moved to the more or less open mouth where they are ingested. This was probably also the case in paleocrinoids, whose disc was covered with a kind of closed dome (homologous to the vestibule of the young in extant crinoids). The intestine of Antedon is filled with a quantity of radiolarians, diatoms, small algae, etc.). According to Carpenter (21), peridinians (Ceratium tripos), globigerimans and radiolarians are the principal food of crinoids at great depths. In young pentacrinoid larvae, from the opening of the vestibule, food is captured primarily by the tentacles.

Most urchins, despite their powerful masticatory apparatus, eat only algae that they gnaw with their teeth (Agassiz, Fewkes, etc.). In dissections, I have always found vegetable cells in the intestine of Strongylocentrotus, Echinus, etc. Prouho (151) reported that hungry Strongylocentrotus sometimes gnaw on the test of others. Dorocidaris papillata, in contrast, eats

\footnotetext{
${ }^{14}$ Fredericq. La digestion des matières albuminöides chez quelques Invertébrés. Arch. Zool. Exp., $1^{\text {re }}$ série, t. 7, 1878, p. 391.

${ }^{15}$ MacMunn. Contributions to animal chromatology.Quat. Journ. Mic. Sc., vol. 30, 1889, p. 51.
} 
animals (Prouho), sponges, gorgonians, fish, crustaceans, and annelids. According to Dohrn (39) Sphoechinus granularis in aquaria is a formidable carnivore that, with its tube feet, can capture large crustaceans such as Squilla mantis. Clypeasteroids dig into the substrate with their teeth, as with a shovel according to Agassiz. Sand with diatoms, radiolarians, etc. are found in the intestine (Echinocyamus, Echinodiscus, Peronella). The intestine of spatangoids is filled with sand that is probably pushed into the mouth by the movements of the peristomial tube feet (ambulacres fouisseurs, Lovén). The lower lip is shaped exactly like a shovel. The great weight of the sand ingested has led to correlated modifications of the intestine, which has a very great development of the mesenteries and thickness of the walls, etc.

Ophiuroids feed on animal prey, dead or inert, that are pushed into the stomach by the peristomial teeth. These are not involved in mastication, or at least their role in this is is very limited. It is rare to find anything else in the stomach. I once found sand (accidentally ingested?) in Ophiocoma scolopendrina. The stomach of an Amphiura squamata had two small crustaceans (probably young decapods) approximately one-half $\mathrm{mm}$ in length. According to Wallich, the intestine of ophiuroids from great depths contains numerous globigerinans.

Asteroids are very carnivorous, as has been known for a long time. They consume little other than animals whatever is their special means of defense. From this point of view, it can be said without emphasis that these are the queens of the aquarium. They feed very well on living animals (urchins, crustaceans, molluscs, etc.) as well as dead prey $\left({ }^{16}\right)$. In some localities, they make great destruction in natural banks of oysters and mussels (de Montaugé, Hodge, White, etc.). Asterias glacialis and most asteroids extrude their stomach to envelope the prey and digest them exteriorly (Deslongchamps, Andrew and Barrett, Rymer Jones, etc.). Astropecten preferentially ingests animals, as Hamann and others have said. They remain for a more or less long time in the stomach that, as well as the disc, can be considerably dilated (mentioned by Carl Vogt and Yung). I have previously (28) cited the case of an Astropecten aurantiacus containing twenty digested Venus ovata. I have found another specimen of the same species having swallowed a Cassidaria ecinophora and a third that had swallowed a Murex brandaris of very large size, complete with the long extensions of the shell!

\section{RESERVE ORGANS}

Organs of reserve are closely connected to that of blood, because in nearly all groups the ameobocytes are filled with nutritive products they will then transport to the tissues. These are various albuminoid material, rarely fat (echinoochrome of urchins and Synapta). Glycogen has not been found in echinoderms (Krukenberg).

Synaptids. - No attempt has been made to experimentally show utilizable reserves in synaptids. It is probable they are represented by the modified amoebocytges that are found both in the coelomic fluid and in the wall of various organs. Some (pl. XXIV, fig.15) are muriform amoebocyes filled with colorless granules, probably protein in composition. The contents are strongly colored by safranin and methyl green. Othrs are mahogany red amoebocoytes filled with fat, echinochrome that osmic acid turns yellowish black. This question of reserves is related to fragmentation of synaptids (154):

\footnotetext{
${ }^{16}$ According to Sluiter, Culcita Schmideliana from seas of Java consume urchins, notably Echinometra lucunter despite its strong spines.
} 
"When synaptids are kept for some time in mud, they fragment. It could be said that the animal, sensing that it cannot obtain food for the entire individual, suppresses successively the parts whose contents would cost too much together, a little like useless mouths are chased from a beseiged city. At the end of some days, only a small spherical balloon surrounded by tentacles remains. The synaptid has fragmented nearly all the body and continues to live with a head." (de Quatrafages, 154.)

By this process the animal decreases in size, but it also decreases its reserves, because it is easy to demonstrate that each fragment of the synaptid contains just as many amoebocytes as the head segment. This phenomenon does not have the importance generally attributed to it. Spasmodic contraction of the circular muscles, coinciding with weakening of connective tissue, leads to fragmentation of the animal. Phascolosoma elongatum Keferstein in the same circumstances shows an analogous phenomenon. The circular muscles contract in places, giving the animal a chambered and quite striking appearance. But there is no consecutive fragmentation because of the thickness and tenacity of the cuticle of Phascolosoma.

Holothuroids. - At least for some holothuroids, it is known that they can remain a long time without food. They eviscerate when they are irritated but do not die afterwards. The digestive tube completely regenerates (in four months, Johnston?). It is necessary for the holothuroids to live on reserves during this period. These are evidently composed of numerous muriform amoebocytes (Plasmawanderzellen de Hamann, Wanderzellen of Ludwig) in so great abundance (especially in Cucumaria) in the interior of all tissues. These amoebocytes are even found in the nervous system (pl. XXVII, fig. 39. They are less abundant and smaller in Holothuria (notably H. impatiens).

What is the chemical composition of these granules? In Cucumaria cucumis, reaction with dyes indicates there are two types of reserve amoebocytes. Staining all of them with boracic carmine and methylene blue, granules of some cells become pale blue or deep blue. These cells appear to be slightly "migratory". They are especially found near the sinus and the coelom. The other larger cells with clearer and more numerous granules are not stained. These are especially fouond in the lacunar layer and deep in the tissues (pl. XXIV, fig. 4). In both cases, the colorless and refringent granules in living tissue are intact in pieces fixed with osmic acid, acids, mercuric chloride, alcohol, etc. These characteristics indicate clearly albuminoid granules. But I have not been able to obtain absorption so characteristic of orange 3 that I do not want to be too positive about their chemical composition.

Crinoids. - We place saccules among the organs of reserve, a little prematurely perhaps because we have not been able to do decisive experiments. But their microscopical and microchemical study allows us to defend this opinion.

Saccules (name of W. B. Carpenter (calcareous glands of Wyville Thompson, Kugeligen Körpor of Ludwig, spherical bodies of Perrier, zooxanthellae of Carl Vogt and Yung) are small spheres (colorless in alcohol specimens) that are found in great number the length of the ambulacral grooves, on the disc, the arms and pininules, alternating with the triads of tentacles (Antedon). They are sometimes found elsewhere, in the wall of the digestive tube (in adults, Ludwig and Carl Vogt and Yung) or at the base of the calyx below the chambered organ (in young larvae, H. Carpenter). In a specimen of Antedon rosacea from the Mediterranean that I sectioned, saccules of all sizes were extremely numerous in the mesenteries near the wall of the digestive tube, especially in the upper circumvolutions. At the base of the anal tube, saccules form a thick annular layer. All these saccules are perfectly like those of the ambulacral grooves and filled with the same products. I have seen one (pyriform mass) even in the interior of the digestive epithelium. 
Their distribution in the crinoids is very capricious. According to H. Carpenter (21) they are very abundant on the pinnules of Antedon species. In some species (Ant. Acala) the lateral plates of the skleton of the pinnule have small cavities wherethey are embedded. Saccules are also found in the pinnules of various Promachocrinus, three species of Eudiocrinus (E. varians, atlanticus, indivisus), more rarely in Atelecrinus, Rhizocrinus, Bathycrinus. Finally, they are completely lacking in Actinometra, Holopous, Hyocrinus, Metacrinus, Pentacrinus, in two specis of Eudiocrinus (E. Semperi, japoniscus). Their distribution is specific and has no relation witih locality. H. Carpenter cited numerous examples showing the dredging at the same station of abundant types with sacccules with others in which they are absolutely lacking.

Histology. - Saccules are completely buried in the mesoderm, one side being very close to the exterior (pl. XXIV, fig. 17). They have no opening to the outside and their wall is as limited superficially as it is deeply. Their contents were well described by Perrier $(139,1873)$ and Bury $(16,1889)$. It is formed of pyriform masses (pl. XXIV, fig. 18), extended at one end by a long very thin tail. It is formed entirely of small colorless, very refringent spherules. When a saccule is dissociated, it generally leaves a large number of pyriform masses whose long extensions remain attached to the wall, nearly all toward the same point. In the intact saccule, the arrangement of the masses is vaguely radial.

Bury described flat cells on the wall of the mature saccule whose role he did not appear to understand. For my part, I have seen a very clear epithelium formed of large nuclei surrounded by a thin, irregular protoplasmic layer, with fine yellowish grannulations to which a pyriform mass attaches. In dissections, the presence of this basal cell with an intact pyriform mass at its end can very often be seen (pl. XXIV, fig. 18). It is thus very probable that the latter with its filament results from the differentiation of a cell. This epithelium does not exist over all the surface of the saccule. It is especially well developed on the deep surface. The wall near the exterior nearly always lacks it (pl. XXIV, fig.17). It is there the filaments are usually attached. Bury, in the figure he gave of the mature saccule $(16, \mathrm{pl} .46$, fig. 44) shows well that the most external wall lacks nuclei but it attaches the filaments to the deep surface. I have always seen the contrary.

Development of the mature saccule. - In order to understand the composition of the saccule, it is necessary to study the development of the pyriform masses. Some saccules do not appear to contain them, or at least they are very small and poorly defined. Nearly certainly these saccules have an epithelium with very clear cells. In the protoplasmic layer above the nucleus are one or two refringent granules. Other cells have a small pyriform mass attached to the protoplasm and a short filament (pl. XXIV, fig. 18). It seems to me that this was only when the mass was well formed with the elongated filament that becomes resistant and goes to attach to the opposite wall.

Development continuing, the number of refringent granules gradually increases. Sometimes the well developed pyriform masses are still attached to the basal cell (fig.18, ep). But most often they are separate, becoming free in the cavity of the saccule, maintained only by their filaments. The nuclei rest on the saccule wall, more or less difficult to see because of the accumulation of spheres (this is probably the stage that Bury describes). Later, when the refringent granules have been resorbed, the epithelium becomes clearer, probably because of the regeneration of the protoplasm and perhaps a new formation of cells.

In the same arm of an Antedon, saccules in all stages are nearly always present, some where the pyriform masses are progressing, others where they are regressing. In the latter, a more or less large number of free granules are found in the center, surrounded by plates probably resulting from the rupture of the masses. The epithelium is very clear and in process of reconstitution. 
Development of saccules in the embryo. - Saccules develop very early in Antedon rosacea. Five small cellular masses are seen when the larva is fixed near the $10^{\text {th }}$ day, located in the radial angles of the water ring (W. Thomson, Ludwig, Perrier, Bury). Each of these masses has the form of a small sunken capsule covered with identical cells with surrounding mesodermal cells. The pyriform masses form early, near the $12^{\text {th }}$ day by the same process as in adults. The refringent spherules accumulate little by little in the protoplasm of the cells of the wall, then forming a mass projecting into the cavity. According to Bury (16) some of the cells become free in the cavity of the saccule, then change as before. But it not quite certain and this could be an optical illusion.

Perrier $(139,1873)$ has similarly described the formation of saccules in developing arms. The process seems to differ little from that we just described. Some cells are seen on the interior of the limiting membrane, a simple specialization of the surrounding mesoderm that little by little fills with refringent spherues.

Chemical analysis of the granules. - The chemical composition of the granules can be studied only with various stains under the microscope: osmic acid gives a grayish yellow tint without affecting their refringence. They thus are not fat, which is confirmed by their insolubility in the usual solvents of fatty bodies. Mercuric chloride, acids and alcohol do not affect them. Finally, they have a remarkable affinity for various dyes, eosin particularly (Perrier, 145). After death of an Antedon, they become red by absorbing the coloring material freed from the skin (Comatulinei). In sections fixed witih picric acid and stained with picrocarmin, they keep a beautiful yellow color. In preparations stained with a mixture of orange, fuchsine and methyl green (see Technique), the granules have a remarkable affinity for the first. In the midst of the other dyes, the saccules can be seen in a glance thanks to the very intense orange color. This process also shows that it is not a single granule of this substance outside the saccules (which refutes, if necessary, the theory of zooxanthellae proposed by Carl Vogt and Yung). We can thus conclude with certainty from the various reactions that the granules are formed of a very condensed albuminoid substances whose development and regression takes place in the saccules.

Functions. - Saccules have been considered successively as glands secreting calcite (Wyville Thomson), excretory organs (Ludwig, Hamann ?), collections of parasitic algae (Carl Vogt and Ung), mucus glands (Bury). The first two opinions scarecely have proponents. The hypothesis of zooxanthellae has been completely refuted by Carpenter (24) and Bury (16) and I believe there is no reason to believe them. Bury claims that mucus exists in the saccules, produced probably by rupture of the pyriform masses. He thinks, not without some hesitation, that the wall of the saccules ruptures from time to time and releases the mucus that fills them. I believe this hypothesis is no more well founded than the preceding ones. The mucus released by living pinnules evidently come from mucus cells of the tube feet epithelium and not the saccules. I have not been able to find with any stain such a product in their interior. In addition, it is quite evident that the histological and chemical makeup is not at all that of mucus glands.

For my part, I think the saccules are only reserve organs, accumulating protein. I must recognize that Walther also had this idea in his work on fossil crinoids $(183,1886)$. Here is what he said: "Their function, according to the literature, is still unknown. According to the following observations: strongly refringent, great affinity for dyes, absence of a cellular structure, polygonal or rounded structure, located at the points of greatest growth and a certain elasticity in their distribution, I think that it is reserve material (nutritive yolk). The excretory functions must definitely be discarded because of the impermeable membrane."

The reasons of Walther, among those that are correct, are not of great value. But the chemical composition of the granules, most certainly albuminoid, their precocious appearance in larvae 
when it begins to feed (the vestibule and the anus are open and the digestive tube is filled with diatoms), the capricious distribution of saccules in various crinoids and even their anomalous position in Antedon rosacea are in perfect accord with their functions as reserve organs. We have shown that the granules develop constantly in living Antedon and that in some cases more or less empty saccules are found, probably to meet the needs of the animal. It is know that eviscerated comatulids (Marshall, Dendy) regenerate their organs very rapidly and repair very extensive wounds, etc. It is thus quite possible they have important reserves that allow them to meet the considerable requirements. As to the nearly always superficial location of the saccules, it evidently is to facilitate excretion and respiration of the organs.

To demonstrate this in a rigorous manner, it would be necessary to do physiological experiments that we have have not been able to do: 1. Starve Antedon in filtered sea water and see if the contents of the saccules are used; 2. Amputate the arms and even remove the visceral mass to see if the nearby saccules become empty, etc.

Yellow cells (yellow connective tissue corpuscles, oil cells, yellow cells). - These are cellular elements discovered byWyville Thomson that are abundant in the integument. They are filled with yellow or greenish yellow granules with indistinct borders whose nature is still strongly debated. These cells are often in the midst of ectodermal cells (figure in 32, pl. 18, fig. 20), notably on the border of amulacral grooves. They can have slow movements in which the granules they contain are clearly perceived. I believe I have observed their amoeboid movements but this requires confirmation because it is denied by most authors, Götte, Bury and Perrier. They are not seen in sections, the reagents (even osmic acid, Bury) destroy the color of the granules.

For Perrier (139) the yellow cells are connective tissue corpuscles. For Bury (16), they are glandular ectodermal cells. I cite only for reference the opinion of Carl Vogt and Yung who thought they were algal amoeboid spores (refuted by H. Carpenter, Bury and MacMunn). I think the yellow cells are migratory amoebocytes because we have seen identical cells that transport reserve products to various organs in echinoids. I have found them free in the coelomic fluid (32). As to their content, I think it is protein but without good reason I admit.

The yellow cells appear in the larva after it has ruptured the vitilline membrane (Götte, Bury). They are very abundant in the pentacrinoid larva (Wyville Thomson) and the adult (Perrier). Thus their appearance is very precocious like the migratory amoebocyotes of urchins (Pluteus) and most reserve organs.

Echinoids. - Urchins can remain a long time without food as low as the surrounding water is sufficieintly aerated.

Reserve products are evidently accumulated in the interior of amoebocytes that occur in great number in all tissues of the animal. Some (muriform amoebocytes) contain colorless, more or less refringent granules within a protoplasmic network. These granules disappear after reaction with reagents like osmic acid. Others are mahogany red amoebocyotes, clearly amoeboid, containing echinochrome (MacMunn, 122) that are considered true fats because of their reaction to osmic acid, ether, etc. (see 32 for more details).

Under good conditions, amoebocytes normally have in abundance either colorless granules or mahogany granules. Once filled with these products, they move into the tissues to be utilized according to the needs of the animal.

Ophiuroids. - Few observations in ophiuroids show the existence of reserves. In aquaria, ophiuroids appear to survive a very long time without food. Observations by Verrill, Semon (166) on Amphiura abdita V. and Ophiopsila aranea show these animals can regenerate extensive wounds of the disc. There are no definite reserve products, neither amoebocytes nor in the organs. 
It is probable that the reserve must be very diffuse, probably in the organic fabric of the calcareous plates as we will see in asteroids.

Only in Ophiactis virens I have a found on this organic fabric, principally near the exterior border (pl. XXIV, fig. 3), numerous cells that very clearly are reserve cells. They measure 10 to $30 \mu$ and contain a very clear nucleus and a quantity of small round granules that show affinity with orange 3 characteristic of albuminoid material.

Asteroids. - In asteroids there are no longer definite reserves, neither in amoebocytes or elsewhere. However, experiments show they exist they exist in great quantity. They are probably in the organic network of the calcareous pieces, filled with numerous cells and anastomosing protoplasmic filaments.

Asteroids can, in fact, live for a very long time without food and even in this state repair extensive wounds. I have cited elsewhere (32) the example of an Asterina gibbosa that had lost by injury the entire aboral disc and digestive tube, and thus all the perivisceral fluid, that completely regenerated the lost parts and reformed a new digestive tube, evidently at the expense of preexisting reserves.

\section{RESPIRATION AND EXCRETION}

There is an advantage to considering excretion and respiration together. In summary, the respiratory organs release carbonic acid and all the products of soluble waste into the water. What characterizes most echinoderms is the great development of appropriately called respiratory organs corresponding to a complete absence of excretory, renal, organs. The products of soluble waste that cannot be expelled outside accumulate in all the tissues (an arrangement compared to the kidneys of accumulation of ascidians).

\section{Synaptids}

All synapatids (Apneumona of Semper) lack respiratory organs. Respiration must be across the very thin skin. The great development of ciliary urns on the internal surface that strongly moves the cavity fluid is without doubt related to this respiratory function of the skin. The role played by the buccal tentacles is not unimportant despite their small size. It is exactly the same in elasipods.

Excretion must result in great part by diffusion because a great accumulation of products of waste are not seen at all. The mass of brown granules that are often found in the general cavity (reported by Leydig and Berlin) generally surround gregarines and their cysts. I do not know if these must be considered excretory products related to the presence of parasites.

In Synapta inhorens, the only particles that can be reported are not numerous and of organic nature. These are small round granules that stain strongly by methyl green and safran after fixation in Flemming's solution. These isolated granules are found in the body wall, in the wall of the ciliated urns, in the coelomic fluid etc. (pl. XXIV, fig. 12). Many amoebocytes contain some in their interior that they evidently have absorbed (pl. XXIV, fig. 15). These granules, which appear to be the products of waste, in any case are not abundant. 
Holothuroids

In molpadids, aspidochirotes and dendrochirotes, the respiratory trees, in addition to their hydrostatic functions (Hérouard), are respiratory. The tube feet have no importance in this regard except for the delicately branched buccal tube feet of dendrochirotes.

In some types, the cavity fluid contains red blood cells. These are more or less irregularly disc shaped and contain hemoglobin (Thyone gemmata, Pourtalès, Cucumaria Planci, Howell, Thyone aurantiaca, Cuénot). Their number varies greatly with the individual (see 32). In Cucumaria Planci, the water vascular system often contains very large numbers of red blood cells. Kruckenberg (93) has expressed doubts about the respiratory importance of the hemoglobin although it appears identical to hemoglobin of vertebrates. The fact is that the red blood cells are often assembled into large pacts that do not seem very appropriate for rapid respiratory exchange. It is equally striking that their number varies with individual. Although I am not clear about the importance of these red blood cells in respiration, it is appropriate to think that their presence, in the species that have them, does not constitute a very great functional advantage.

The very thin body wall of the respiratory trees is formed of an easily removed internal epithelium of flat cells, a connective tissue layer formed of fibrils and a fundamental substance with gelatinous consistency, muscle fibers arranged in all directions but mostly circular, and finally a ciliated peritoneal epithelium. Immediately below the internal epithelium are often found masses of yellow granules (excretory products) reported by Semper, Jouordan, Hamann, Hérouard. Finally, in the connective tissue layer, as also in all tissues of holothuroids, are large numbers of muriform amoebocytes.

For the functioning of the respiratory trees, I refer to the excellent description of Hérouard. There is however one thing I cannot accept. Hérouard thinks these probably are lymphatic (amobocytogenic glands, according to his expression). This is not my opinion. In fact, the muriform amoebocygtes included in the wall are migratoroy cells, already very far from their original state, seeing that they are filled with reserve products. They are certainly not formed in the respiratory trees that contain them just like all the other tissues of holothuroids.

Excretory products. - Waste products are accumulated in masses, sometimes very large, in all tissues and preferentially in the respiratory trees, Polian vesicles, mesenteries, lacunar tissues, etc. I have seen them in all species I have studied (Thyone aurantiaca, Cucumaria Planci, cucumis and Lacazii, Holothuria tubulosa and impatiens, Stichopus regalis). They are made up of fine round granules of various sizes, with a beautiful yellow color when fresh and very refringent. We will examine their chemical characteristics later. In sections, they are very irregular granules of various sizes. Some are yellow, some blackish (the largest are black). I have not been able to find crystalline forms. There are many free in the coelom, the fluid of the water vascular system, Polian vesicles (the mass sometimes measures several millimeters and are the brown bodies reported in the literature. They are also found in the interior of amoebocytes. These have been absorbed, like they absorb all solid material, by phagocytosis. It is quite probable that they finish by expelling them again into the tissues. It is important to note that these yellow granules are not found in cells, as has been incorrectly said. They form irregular masses that can enclose a variable number of nuclei included mechanically but they themselves are clearly extracellular. There is no reason to think that the yellow granules result from the destruction of amoebocyotes as many think. They are breakdown products of the organism in general. 
In the lacunar layer of the skin, the waste products often accumulate in great quantity and produce a characteristically blackish speck that is striking in Cucumaria and Stichopus. They are formed by granules that are different than those accumulated in other organs and most often are blackish or brownish.

Most of these waste products remain indefinitely in holothuroids that cannot eliminate them. However, a small quantity is expelled by the respiratory trees as Hérouard has shown. It happens that the internal epithelium, under the weight of the mass of granules, can be detached so that they are released to the outside. In fact, they are often in the water expelled by these organs.

It is quite certain that the yellow granules are waste products. They are noticeably more abundant in old individuals than in young ones. Their manner of occurrence in the tissues, their non-cellular nature, the release of part of them by the respiratory trees all agree to prove this. This is moreover the opinion of all who have studied holothuroids.

As to the chemical nature of these granules, I have not been able to determine it. They are insoluble in cold concentrated acids, sulfuric, nitric and hydrochloric. They are equally insoluble in hot and cold hydroxides, ammonium and potassium. Finally, when an organ that containes them is burned, deep brown intact granules are found in the residue. These reactions show that the granules in question are not formed of uric acid, urea or urates, nor by one of the xanthic series (guanine, xanthine, etc.). Carus (18853) reported guanine in the respiratory trees of various holothuroids. This very old claim has never been confirmed (Selenka). For my part, I have sought guanine and xanthine in Cucumaria cucumis and Holothuria impatiens and have never found a trace.

\section{Echinoids}

Intestinal siphon. - It is thought that the perivisceral fluid respires by means of the intestine. In fact, that is done by the intestinal siphon (name of Perrier) or Nebendarm, a kind of sunken tube opening at its two ends into the digestive tube, one not far from the esophagus and the other in a part of the intestine lacking absorbing lacuna (second curve). This siphon allows water swallowed by the urchin to bypass the intestinal tube without entering the truly digestive and absorbing portion. The walls are sufficiently thin for diffusion to occur easily. The current of water must be attributed to the cilia of the pharynx. However, precise data about this are still lacking.

The siphon is lacking in Dorocidaris papillata (Prouho, 151). Perhaps it is replaced from the morphological point of view (and even functional) by a kind of epithelial gutter that is found in the interior of the intestine, beginning and ending at exactly the points where the siphon usually opens. The siphon has been described in all other regular urchins studied from this point of view. Its structure is similar to that of the intestine. The internal epithelial layer is formed of cylindrical, non-glandular cells (Kæhler, Hamann).

The intestinal siphon is present in all clypeasteroids that I have studied (Echinocyamus, Echinodiscus, Peronella). It is a cylindrical tube (pl. XXIV, fig. 16) that leaves the esophagus some millimeters below the matiscatory apparatus, makes a more or less accentuated curve and goes to open into the intestine, either opposite inerradius AE (Echinocyamus) or near interradius AB (Peronella, Echinodiscus). The siphon has the same histological makeup as the intestine. The epithelium is not very tall.The wall of the digestive tube, much thicker where it leaves the 
esophagus, begins to decrease in thickness a little after the opening of the siphon. All of the part of the intestine located in radius $\mathrm{C}, \mathrm{B}, \mathrm{A}$, has very thin walls (Echinocyamus).

It is evident, although I have not been able to make studies in vivo, that, as in regular urchins, the portion between the two openings of the siphon is very glandular and is active in digestion and absorption.

In spatangoids, the siphon is arranged nearly like that in the preceding types, the portion between its two openings being very glandular and provided with numerous absorbing lacunae (Kæhler). Kæhler (87) has discovered a second accessory siphon in Schizaster, Brissus, and Brissopsis. It is very small with a very variable arrangement. Its functions do not seem to me to be identical to that of the first siphon. Hamann has confirmed the results of Kæhler and has studied the histology of this accessory siphon (69).

Physiology. - It is Perrier, in 1875, who has demonstrated by precise experiments with Echinus microtuberculatus the role of the intestinal siphon in the transport of water from one end to the other of the intestine. This current of water is evidently related to respiration of the cavity fluid. I do not doubt that these facts are identical in clypeasteroids. The anatomical arrangements, at the very least, absolutely confirm these results.

Has there been repetition of these experiments with Dorocidaris that lacks the intestinal siphon and for spantangoids? When the digestive tube of the latter is absolutely filled with sand, the current of water should not be very important and respiratory diffusion should be much reduced. I recall thatMarion and Kæhler, in the spatangoid, have not proven movement of water by the siphon. In the regular urchins and clypeasteroids, at least in some cases, the digestive tube is filled with food, sometimes sand, and, so that it has a very efficient current. We know nothing more about the role of the accessory siphon of Schizater, Brissus and Brissopsis.

In summary, although the respiratory role of the siphon and the intestine is not disputed, it is however possible there there would be interruptions in this function when the digestive tube is completely filled by inert material, obstructing too much of the lumen for the current of water to be possible.

From the phylogentic point of view, it is quite probable that the intestinal siphon of various urchins derives from the same ancestral formation. The connections are too similar for them to have developed independently. But in this hypothesis, it becomes incomprehensible that the siphon is lacking in Dorocidaris, to admit at least a regression that would have made it disappear. The present state in this type would thus not be primitive but secondary.

Respiration. - The peripharyngeal liquid respires by the external gills or, when they are lacking, takes the necessary oxygen to the coelomic fluid. Thus it is separated only by a very thin membrane, sometimes having special diverticula facilitating diffusion (Stewart's organs, dental sacs).

The tube feet have a very great importance from the respiratory point of view, either only by petals (clypeasteroids and spatangoids) or in all the perforations of the cornal plates (regulars). In all respiratory tube feet, the external part, more or less a sac or extended (pl.XXVII, fig. 38; pl. XXVII, fig. 56) communicates with the internal vesicle by two pores. Moreover, the mucular bundles that cross the cavity are arrange so that the current determined by the internal cilia is nearly constantly circular, the liquid passing by a pore from the external to reenter into the internal vessel by the second pore. The oxygen absorbed by the tube foot liquid passes in large part by diffusion into the coelomic fluid. Respiration is thus mediated by the by the tube foot. The coelomic fluid, according to the results of an analysis by Mourson and Schlagdenhauffen (127) is less oxygenated and contains more carbonic acid than the surrounding sea water. 
Excretion. - It is very probable that a good part of the broken down substances pass to the exterior by diffusion. The rest is fixed in the tissues in the form of colored granules, sometimes crystalline, recalling exactly those we have described in holothuroids. Mourson and Schlagdenhauffen (127) have reported in the coelomic fluid of Stronylocentrotus lividus the presence of urea ( 0.01 to $0.013 \mathrm{~g}$ per $1000 \mathrm{~g}$ of liquid) and of leucomaine in small quantities it is true. We have presumed without proof that this leucomaine resulted more specially from development of gametes.

The colored granules accumulate indiscrimately in all tissues. There are few or none in young individuals while samples of aged specimens are filled with them. That is understandable because these excretory products cannot be eliminated. They are found in all cidaroids (Prouho), echinoids and spatangoids examined. They are much less in cylpeasteroids. The granules are found especially in lymph glands (axial gland, spongy vesicles), in mesenteries, lacunar tissues (intestinal, genital, radial lacunae, etc.), in the wall of the digestive tube, test, etc. They even are found sometimes in the interior of nerve cords. In old Spatangus purpureus notably, the calcareous netework of the test and even the external epithelium contain considerable quanties. Finally, there are free masses in the coelomic fluid and consequently in the interior of amoebocytse (figures in 32, plate 18). In sections of living individuals, the granules are yellow, brown or black, very refringent, and variable in size. The largest are found and generally are found in the center of the mass of fine granulations. At very high magnification, the smallest yellow granules (especially in Strongylocentrotus lividus) they are clearly small crystalline cubes with slightly curved surfaces (figures in 32, pl. 18, fig. 12 and 13).

Their chemical composition allows us to identify them with the yellow granules of holothuroids. They are insoluble in hot and cold ammonium and potassium solutions, as well as in cold mineral acids.

History. - There is no organ that merits the name kidney in urchins. The abundance of waste products has often led attributing this quality to the axial gland (Jourdain, Perrier, Kæhler, Hamann, and more recently the cousins Sarasin, 159), but this proves only that the gland has high activity. The presence of granules has no functional significance because there are also many in other connective and lacunar tissues.

Giard $(1877)\left({ }^{17}\right)$ has attributed to the gonads (Echinus microtuberculatus, Echinocardium cordatum), during the non-mature periods, an excretory function based on the presence of colored granules in yolk cells that remain in the walls after spawning of the sperm and ova. These are probably waste granules as they are found everywhere and their presence is no more significant for the gonads than they are for the other tissues that contain them.

Kowalevsky (1889), in his investigations on excretory organs $\left({ }^{18}\right)$ injected a solution of ammonium carminate. Note that in these circumstances, the axial gland is stained red and the spongy vesicles (Polian vesicles) remain colorless. He concluded that the first excreted carmine and had an acidic reaction. I have already criticized Kowalvesky's conclusions. I still have the same opinion about this. Fixation of carmin in an organ cannot be related to an excretory function.

\section{CRINOIDS}

\footnotetext{
${ }^{17}$ Giard. Sur une function novelle des glandes génitales des Oursins. Comptes rendus. Ac. Sc.. Paris, 187, v. 85, pl. 858.

${ }^{18}$ Kowalsky. Ein Beitrag zur Kenntnis der Exkretionsorgane. Biol. Centralblatt, v. 9. 1889 (analysis in Arch. zool. exp. $2^{\text {nd }}$ series. v. 7, 1889. Notes et Revue, p. 34).
} 
Respiration. - It is usual to consider, since Müller, the anal tube as a respiratory organ. In fact, this organ is is filled with circular muscle fibers and in constant movement in living animals, alternatively taking in and expelling sea water. It is possible that the current of water thus plays a role in respiration. However, to decide this formally, it is necessary to place living Antedon in colored water and see if there really is osmosis as can be shown for the respiratory organs of other echinoderms.

The tube feet, whose walls are very thin, probably have a great respiratory importance for the liquid of the water vascular system. Finally, the role of vibratile funnels from this point of view is still doubtful, and for my part, I believe it is more prudent to retain the question.

Excretion. - In the calcareous network of the calcareous pieces and in the mesenteric chambers of the visceral sac are found masses of granules that really seem to be the products of breakdown. To see them well, it is only necessary to stain a section with methyl green. These granules are stained in fact, more less strongly a dull green. In the mesenteric bands are very irregular masses of refringent colorless or slightly yellowish granules. With high magnification they appear as cuboid crystals or sometimes small regular prisms. Although they could have no importance for the visceral sac, the crystalline masses are always abundant near the esophagous and in the poart of the viscereal sac beneath the oral disc.

The mass of the calcareous network of the test are formed of crystals and large rounded granules that take on a dull green color with methyl green. These masses are verey irregular and more or less abundant according to the individual (perhaps in relation to their age). All I can say about their chemical properties is that they are insoluible in mineral acids.

\section{OPHIUROIDS}

Respiration. - The respiratory organs have been well known since the nice work of Ludwig (1878). They are respiratory sacs (genital bursae), a kind of invagination of the skin to the right and left of each arm. These ten bursae are found in ophuroids and euryalids with differences in detail, notably in the genus Ophioderma where the space is divided into two. They are lacking in Ophiactis virens, a species also aberrant in its mode of asexual reproduction.

The bursae have a very thin wall formed of a very vibratile internal epithelium with a thin connective tissue layer and a ciliated peritoneal epithelium. In the interior the internal epithelium (sections stained with safranin) has flattened undifferentiated cells with projecting rows of special cells (very ciliated according to Hamann) with very small nuclei that are strongly stained by dyes (p. XXIV, fig. 14). When they are very dilated, the bursae completely fill the space between the organs of the disc. Their volume is moreover intimately connected with that of the gonads that lie on them.

In Ophiothrix fragilis and Ophiocoma scolopendrina, they have an unusual arrangement. Each of the bursae in the same interradius, one to the right and the other to the left of two adjacent arms, send a diverticulum that penetrates into the interradial muscle. This very large muscle is formed, as is known, of numerous horizontal intertwined faschia. In Ophiocoma scolopendrina (pl. XXV, fig. 29), the two diverticula ramify and pass, so to say, between the faschia of the muscle. In 
Ophiothrix, the arrangement is simpler. The diverticula descend simply into the muscle mass where they are easily seen in horizontal sections. Their histology is otherwise like that of the sacs.

Phyisiology. - Sea water circulates continuously in the sacs, first under the influence of ciliary currents and also because of raising and lowering of the discs. These are true respiratory movements that are easily seen in living individuals. Their respiratory function is without doubt. In Ophiactis virens, where they are lacking, they are replaced, as we shall see, by the water vascular system. This is greatly developed and filled with red blood cells with hemoglobin. They also have a role in hydrodstatic equilibrium, their development being inverse to that of the gonads.

As for the diverticula that penetrate into the interradial muscle, I do not believe that they are there only for respiration and excretion of the muscle. Perhaps their movement during mastication contributes to the movement of wataer in the interior of the burasa. In any case, their importance should be very secondary because I have found them only in these two species.

Finally, it is known that the gametes are expelled by the exterior slit and that in viviparous species (Amphiura squamata, Ophiacantha marsupialis Lyman), the embryos develop in the interior of these bursae. In Amphiura, their formation is relatively late. Shallow invaginations in these young individuals $(\mathrm{D}=1.5 \mathrm{~mm}$ ) reach their normal size only after the first spawning. The histology of these bursae is moreover identical in this species to that we have described for the others. It is quit probable that the role of the matrix has very little effect on respiration.

Excretion. - Excretion in large part must be by diffusion across the bursae. No accumulation of waste products is found either in any organ or in tissues. Some yellowish granules I have rarely found (calcareous network, Ophioglypha lacertosa) can perhaps be referred to them.

It is completely different in Ophiactis virens in which the bursae are completely absent. Numerous floating yellow, irregular granules formed of very clear small granules are found in the water vascular system and also in the coelom, expecially in the Polian vesicles. These granules are completely like those of holothuroids and urchins. There are also many of them in the body wall, the calcareous tracts, etc. These black or yellow granules, perhaps different from those of water vascular system, are either enclosed in large mesodermal cells of approximately $10 \mu$ that they fill completely or scattered on the tracts. The black ones are rounded granules. The other very refringent yellow ones are much smaller and appear to be cuboid prismatic crystals. But they are so small that I have not been able to define them with the magnification that I have. Their chemical nature appears to me to be the same as for the excretory granules of the other groups. All that I have been able to observe is that they are insoluble, as they are, in mineral acids.

\section{ASTEROIDS}

Respiration. - In asteroids, the respiratory organs are also formed by differentiation of the integument. They are small caeca projecting into the external environment (papulae or lymphatics, tubules, Hautkiemen, Kiemenbläschen) that are very characteristic of the class (they are missing on in Brisinga coronate according to Ludwig). The histological makeup is very simle: an external epithelium with long cilia, very richly enervated, a connective tissue layer with longitudinal and circular muscular fibers, and the ciliated peritoneal epithelium. I have no details to add. Hamann, Carl Vogt and Yung and I have reported at the top of the papulae a small thicknening of the internal epithelium. I have confirmed in serial sections that this thicknening really does not exist. The connective tissue wall at this point is taller than the others and, if the section is slightly oblique, 
the epithelium is cut tangentially and thus seems to form several layers. It is known (Ludwig, Teuscher, Hamann, Cuénot) that the papulae are surrounded at their base by a closed cavity that plays a role in closing the papula, as the perianal space does for holothuroids and urchins. This cavity is embedded in the connective tissue and has no epithelial covering (Cuénot). I refer to my work on asteroids for the study of the different forms of these organs in Culcita, Luidia, Astgerina, etc. and for figures (28).

It is not difficult to demonstrate the respiratory function of the papulae that have such a large surface for diffusion. It is easy to demonstrate by putting the living animal into water colored with an inoffensive aniline salt.

The tube feet play only an insignificant role from the respiratory point of view. The walls are, in fact, very thick and moreover, at least in the stationary animal, are always contracted.

Excretion. -Excretion must occur entirely across the wall of the papulae, as in ophiiuroids. In fact, no solid waste products accumulate in the tissues, as in holothuroids, urchins and crinoids. Thus there are very great differences in the process of excretion in astereoids and ophiuroids on one hand and the other echinoderms on the other hand.

Carus (1873) reported the presence of guanine and Milne Edwards of uric acid in the stomach caeca of asteroids. Müller and Troschel, Krukenberg and I have investigated these products without results. Moreover, the histology of these caeca being identical to those of the very glandular parts of the digestive tube, it is completely improbable that they have an excretory function (see 28, p. 43). More recently, Griffiths (1888) said he found uric acid in the stomach secretion (especially in the five dilations that project at the origin of the arms) in Asterias rubens. He concluded that the wall of the gastric pouoches have a role in excretion. But his assertions relative to the presence of uric acid in leeches, earthworms and crayfish, being completely contradicted by M. Marchal ${ }^{19}$, it seems very doubtful to me that this acid exists in the stomach secretion of asteroids. Griffiths was probably mistaken again because of some unreliable reaction.

Hamann $(1885,68)$ considered the axial gland as an excretory organ (chromatogenic organ). Kowalevsky (1889) attributed this function to the Tiedemann bodies (according to the localization of carmin injected into the water vascular system. These opinions do not seem acceptable to me, the axial gland and the Tiedemann bodies being completely characteristic lymph glands that contain no substance that could be related to a waste product.

\section{HYDROSTATICS}

Under this title I consider the processes by which echinoderms reach equilibrium between the interior pressure and that of the surrounding medium. It is also the study of the processes used to become turgid. These questions are very important in the group because of the calcification or the non-elasticity of the body wall.

Introduction of sea water in some circumstances into an animal still remains a very controvserial question. It is very difficult, in echinoderms, to accept that it takes place during spawning. In fact, in most types, the gonads, at the state of maturity, occupy a considerable part of the coelom, compressing the other organs. After spawning (which lastz some hours or even days), there is a considerable change. How can the volume of eggs or sperm spawned be replaced? Because of the rigidity of the walls (especially urchins), the body cannot be contracted as in

\footnotetext{
${ }^{19}$ MARChal. Contribution a l'étude de la déssimilation de l'azote, etc. Bulletin de la Soc. Zool. de France, 1889.
} 
annelids, molluscs, etc. And I think the dilation of compensatory organs (digestive tube, respiratory organs) cannot match the considerable decrease in volume of the gonads. In consequence, it is necessary to accept that at this moment a certain quantity of sea water must be introduced into the organism (I do not know how) to equalize the interior pressure with the exterior. Precise experiments will be necessary to decrease a little the obscurity where we are regarding all these physiological questions.

Synaptids. - In an expanded Synapta, the integument is far from its maximum extension. They are only moderately dilated. If the synaptid is irritated at some point, the segment touched contracts slowly and moves the liquid it contains to the rest of the body, which swells proportionally. If the contraction occurs over some length, the pressure increases in the rest of the body to the extent that the wall swells enormously and is not slow to burst. This always happens when an intact synaptid is placed in a reagent such as alcohol or sublimate. All the muscles contract spasmodically, the body ruptures and the viscera are ejected through the opening.

Synapatids thus have no way (except by rupture) to decrease the volume of the internal liquid. I cannot explain why Petit (149) thought the animal could expel water contained in the general cavity through the anus. All the small increases in the internal volume (digestive tube filled with sand) are easily understood by a corresponding dilation of the body wall.

Holothuroids. - In holothuroids, the hydrostatic processes are much better known thanks especially to the excellent description of Hérouard (73).

If a holothuroid is well expanded, with its buccal tentacles evaginated and limp, rapid intake of water results in ejection by the anus of all the water contained in the respiratory trees. Its tentacles are invaginated at that time, then the anus is closed and the animal has the rigidity of a solid body, all the muscles being contracted. It is easy to analyze the phenomenon. Contraction of the tentacles has led to an increase in pressure inside the body, the internal vesicles swell proportionally. Moreover, the buccal disc and the tentacles are withdrawn to the interior of the pharynx. Finally, the radial muscles contract. This shortens the animal and consequently decreases its internal volume. In order to accommodate this increase in pressure, it is thus necessary that all the available water be expelled by the respiratory trees. As Hérouard has said very well, to make a holothuroid remain completely expanded, it is sufficient to close the anus with forceps or a ligature in a way to prevent expulsion of water from the respiratory trees.

For dilation, the process is inverse. The radial muscles relax, the body swells and elongates by the entry of waer into the respiratory trees. These are thus a kind of regulator to maintain the equilibrium of the interior medium by their dilation and passive contraction.

Echinoids. - The hydrostatic processes are very complex and very obscure in urchins, whose test is quite rigid. The extension and retraction of the tube feet produce very notable changes in pressure, but that are easily compensated by the digestive tube and the peripharyngeal membrane. When the internal ampullae are filled and the peripharyngeal cavity (and Stewart's organs or the dental sacs if they are present) are compressed. Consequently the peribuccal membrane is pushed outward. It is probable the external gills also swell as a result of the movement of the peripharyngeal liquid. When the ampullae are contracted, the contrary effect is produced. As Prouho (151) correctly noted, it is useless to attribute a compensatory role to the stone canal. The deformation of the flexible membranes (that can be proven experimentally by injectiing water into the coelom) suffices sufficiently to compensate the small differences in pressure produced by action of the tube feet.

But it is more difficult to give a complete account of the action of the digestive tube. Sometimes it is filled with sand or food and consequently occupies a considerable space in the coelom. Other 
times it is empty and its walls are applied against each other. It is evident that, in the first case, a notable quantity of coelomic fluid has been expelled outside in order to accommodate the dilation of the intestine. In the second case an equal quantity of waer must enter into the organism. These changes are actually very slow but they exist never the less. Is the uptake and expulsion of water by filtration across the organic network of the calcareous pieces? It is quite possible, because we have shown that they can be displaced in this network that often appears to have canals. Perhaps also the madreporite, by means of its communication with the easily permeable axial gland plays a role in maintaining equilibrium. In the absence of precise experiments, it is better to reserve the question.

Ophiuroids. - Ophiuroids cannot have very great changes in the interior volume. The increase in pressure resulting from the development of the gonads is easily compensated by a corresponding depression of the bursae (or of the esophageal wall in Ophiactis virens, in which the bursae do not exist). The bursae are the compensatory organs, just like the respiratory trees of holothuroids.

Asteroids. - In asteroids, the digestive tube and the papulare are susceptible to compensatory changes. When the asteroid is quiet and in good health, the papulae are turgid, thanks to a slight compression produced on the coelomic fluid by the muscles of the body wall. When the asteroid wants to extrude its stomach for external digestion of prey, the muscles of the body wall contract, all of the available liquid is pushed between the buccal walls and the exophagaus so that it is evaginated outside the animal.

When the digestive tube is retracted into the interior, the muscles of the body walls relax, those of the esophageal bands are contracted, coelomic fluid enters the arms while the esophagus, obeying the exterior pressure, retakes its normal place.

\section{NERVOUS SYSTEM}

The nervous system in echinoderms has at most three parts: 1 . The first, perfectly constant in all classes, of ectodermal origin, forms what can be called the epidermal nervous system that mainly innervates the skin, the tube feet and the digestive tube. 2 . The second has considerable variability. Sometimes it is quite reduced as in urchins, sometimes it is very well developed as in synaptids, holothuroids, ophiuroids and asteroids. It is probable it is at least in part of mesodermal origin, but that is not certain. This second system that can be called the deep nervous system, more specially innervates the motor muscles. 3 . The third part is equally very variable. It is completely lacking in synaptids and holothuroids but is enormously developed in crinoids. It is certainly of enterocoelic origin, being derived from the peritoneal epithelium. I shall call it the enterocoelic nervous system. It is especially involved in innervations of muscles.

Evolution of the epidermal nervous system. - It is in asteroids that the ancestral physiognomy is best retained. It is thus that we shall commence its study with them.

Asteroids. - All around the mouth and in the radial grooves, the ectoderm is greatly thickened over a cavity (oral sinus, radial sinus) (pl. XXV, fig. 21 and 22). The epithelial cells there are very long, the nucleus being relegated to the external side. Between the cellular filaments runs a thick layer of nerve fibers, circular in the ring, longitudinal in the radial nerves, with some ganglionic cells included. The epithelial cells have a thick ciliated cuticle. On the opposite side, they insert into the adjacent connective tissue. It is this epithelial ensemble of nerve fibrils that constitute the central parts of the epidermal nervous system. It is moreover entirely continuous with the rest of 
the ectoderm on one hand and the entodermal wall of the digestive tube on the other. The nerve bands are continued laterally onto the tube feet and form an epithelial-nervous covering (see the diagram, pl. XXV, fig. 24). Between the tube feet, they are continuous with the epidermis of the body, providing the peripheral plexus. Fibrils are particularly abundant in the very sensitive regions (pedicellaria, papulae, etc.). At its end, the radial nerve covers the terminal tentacle with the ocular cup at its base.

The oral ring, equally continuous with the surrounding ectoderm (pl. XXV, fig. 22) cannot be separated from the epithelial covering of the digestive tube. Its fibrils, especially numerous in the esophageal portion, go into this endodermal epithelium and innervate the entire intestine.

Crinoids. - The epidermal nervous system of crinoids, slightly reduced, is exactly the same as that of asteroids. In the ambulacral grooves of the arms, pinnules and disc is found a thick ectodermal band formed of tall ciliated cells with nerve fibrils running longitudinally below them. These radial bands are extended onto the tentacles forming the epidermal covering. It is continuous with the ectoderm of the lappets and the disc in giving them an extremely reduced fibrilar plexus. The five radial bands extend around the mouth in a ring formed by the buccal epithelium, enclosing here very thick circular nerve fibers. This ring is continuous on one hand with the surrounding ectoderm and on the other with the covering the digestive tube to which it gives nerve fibers (figures in Ludwig, Carpenter, Perrier, Hamann, etc.).

Evolution of the system in other echinoderms. - In ophiuroids, echinoids, holothuroids and synaptids, the epidermal nervous system loses its connections with the ectoderm. The entire length of the radial nerves and the oral ring in all its circuit are sunken into the surrounding mesoderm by a more or less characteristic invagination. This process, that obviously has the function to more effectively protect the central nervous system by sheltering it in the depth of the tissue, has some interesting consequences. 1. The histological makeup of the radial bands and the oral ring is constant in all the groups. They are formed of epithelial cells, sometimes even covered with a cuticle, a nucleus near the external edge, that are attached at their base to a membrane of connective tissue. All the free space between the cellular filaments is filled with nerve fibers. 2 . The adults of some groups (ophiuroids, urchins, gnathostomes) and in all young, the oral ring remains continuous with the esophageal epithelium to which it gives nerve fibers (pl. XXV, fig. 28). 3. At their extreme end, the radial bands always fuse with the external epithelium of the body (pl. XXVII, fig. 40, 41, 42 and 43). In fact, it is at this point that the invagination ends. 4. The radial bands and the oral ring, now that they are not continuous with the ectoderm or the surrounding endoderm, produce true nerves with a defined form. The ring gives nerves to the digestive tube and its adjacent parts (buccal tentacles, muscles of the peribuccal pieces, etc.). The radial bands give nerves destined for the tube feet and integument (peripheral plexus). 5. Between the invaginated nervous system and the skin is found a cavity, part of the enclosed exterior environment enclosed in the tissues by invagination completely homologous at least in ophiuroids and urchins. Like the ependyme of vertebrates, the sub-neural or epineural sinuses contain naturally a circular cavity just below the oral ring and five radial sinuses just below the radial bands. It is unusual that these cavities are completely missing (synaptids).

History and names of the epineural cavities. — This system of invaginated cavities has been known for a long time. But authors in general have attached them to another system of frankly schizocoelic origin and a completely different importance, formed by the radial sinuses and a subjacent oral ring with nerve cords ( $s$ in various plates). For Ludwig, Koehler, Hamann, etc., these two types of cavity form perihemal or perineural canals. Prouho (1888) separated them in fact in Dorocidaris, calling the part beneath the nervous system the intraneural cavity and the subjacent 
part the perineural cavity. In ophiuroids, I (1888) have insisted on the fundamental difference in establishing two types of cavities according to their mode of origin and the relation. I have called them respectively subneural sinus and vascular sinus. Hérouard (1889) likewise separated them in holothuroids. The cavity beneath the nerve cords forms by itself the extraneural cavity. That which is beneath it is the subneural canal. Finally, Ludwig, at about the same time (1890), joined the point of view of the three French authors, in a way that this question appears definite. The follow table summarizes the very complicated synonomy of the two systems of cavities. I have omitted those authors who have improperly interpreted these canals and those that have cited them only in passing (J. Müller, Greef, Teuscher, Danielssen and Koren, Théel, Jouordan, Semon, Vogt and Yung.

\begin{tabular}{|c|c|c|}
\hline & $\begin{array}{c}\text { Cavities of sub-neural } \\
\text { invagination }\end{array}$ & Sub-neural schizocoels \\
\hline Name adopted in this work & Ring and epineural sinuses & Oral sinus. Radial sinus. \\
\hline (178) Teuscher, 1876. & \multicolumn{2}{|c|}{ Perineural vessels } \\
\hline Ludwig, Koehler, Hamann. & \multicolumn{2}{|c|}{ Perihemal canals } \\
\hline (151) Prouho, 1888 (urchins). & Intra neural spaces & Perineural spaces \\
\hline (147) Perrier, 1888. & \multicolumn{2}{|c|}{ Sub-ambulacral cavities. Labial ring. } \\
\hline (29) Cuénot, 1888 (ophuroids) & Ring and sub-neural sinuses. & Ring and vascular sinuses. \\
\hline $\begin{array}{l}\text { (78) Hérouard, } 1899 \\
\text { (holothuroids). }\end{array}$ & Extraneural spaces. & Subneural canals. \\
\hline $\begin{array}{l}\text { (114) Ludwig, } 1890 \\
\text { (holothuroids) }\end{array}$ & Epineural canal. & Pseudohemal canal. \\
\hline
\end{tabular}

Importance of ectodermal cells of the neural centers. - It is to be noted that the neural centers of echinoderms contain only an insignificant quantity of typical nerve cells, i.e., filled with more or less numerous extensions. This absence has been shown by several authors who denied the neural importancde of the centers and who looked elsewhere for the usual nerve cells.

In fact, the ectodermal cells, instead of differentiating into ganglionic cells, as happens in other animals, arthropods, annelids, tunicates, vertebrates, etc., keep their epithelial form exactly like the anterior part of the dorsal nerve tube in Balanoglossus (Kæhler) $\left({ }^{20}\right)$. One side is enlarged and contains the nucleus, little protoplasm, a cutilcle and sometimes ciliated cells. The other side is extended in a long very thin, more or less wavy, filament that inserts on the underlying connective tissue. This form is characteristic of all echinoderms without exception. What is the significance of these cells? Are theey supporting cells, as Hamann thought and as their form logically suggests? Are they, to the contrary, nerve cells, as believed for urchins, ophiuroids and holothuroids by authors who have mistaken their true histology? For me these cells that appear to be epithelial correspond from the organogenic and physiological point of view, are ganglionic cells that are found in the nerve centers of other animals. They are ectodermal in origin as in the latter. Their position and their manner of having a relation with the fibrillar part are identical, to such a point that an unbiased observer who examined a section of the nerve cord of an ophiuroid or urchin would undoubtedly identify the mass of nuclei on the external surface as nuclei of nerve cells. It is what most authors who have studied the nervous system have dpme. Their form alone places an obstacle to this interpretation. It is quite true that it is very aberrant for a nerve cell, and I believe

${ }^{20}$ KÆHLER. Contributions a l'études de Entéropneustes. Internat. Monats. Anat. u. Hist., v. 3, 1886. 
that we find in a similar example only in Balanoglossus. But this same objection can be raised: in fact, some organs that are the seat of reflexes, such as tube, spines, etc., receive nerves that I will call ganglionic because their fibrils are accompanied by a large number of nerve cells. Sometimes these are uni- or bipolar, i.e. typical. Sometimes they take an epithelial form (tube nerves of holothuroids, for example) like the cells of nerve centers. Their nuclei become terminal and their cell body is reduced to a thin filament that perpendicularly crosses the layer of fibrils (pl. XXVII, fig. 45). The same thing can be observed in the plates of the plaques of the deep system whose cells are sometimes typical and sometimes epithelial in form (holothuroids, echinoids, asteroids) and also for the enterocoelic nervous system. From these three indisputable observations come this important fact: from obviously homologous cells embedded in the nerve center or ganglionic cells have either the form of typical nerve cells or the appearance of epithelial cells. We thus must conclude that the ectodermal or mesodermal cells of the centers and of nerves that have kept or acquired the epithelial form do not correspond, physiologically speaking, to ganglionic elements. This conclusion makes very clear the makeup of the different parts of the nervous system of echinoderms. It is moreover possible that some among them lose the epithelial form to take the structure of multipolar cells. In any case, they never form a tiny minority.

It is evident that the extensions of the peripheral cells have a role also in supporting the nerve fibers that cross them. In isolated nerves (e.g., in ophiuroids), sometimes filaments detach from the connective tissue Schwann's cells that more or less penetrate the nerve mass. They are supporting elements.

I will say nothing about the fine structure of the nerve elements. Their small size makes cytological examination extremely difficult. Scarcely anything can be seen that corresponds to the results obtained with other invertebrates by F. Nansen and Leydig.

Nervous system of asteroids. - I summarized above our knowledge of the epidermal nervous system of asteroids. For more details, I return to the works of Hamann (68) and mine (28). The deep nervous system remains to be studied. If serial transverse sections are made (pl. XXV, fig. 21) for some length of the radial canal, preferably with Asterias glacialis or Astropecten aurantiacus, the thick radial band is seen first. It extends laterally on the tube feet or the skin. It is above a large cavity, the radial sinus crossed by a septum. It is glandular in the first species. The radial band is fromed of: 1 . an ectodermal epithelium with an external nucleus enclosing a thick layer of nerve fibrils wih some included cells. 2. A thin connective tissue-muscular layer on which the septum is inserted; 3 . The epithelium of the radial sinus, formed of small cuboid cells, each wih a cilium. It is necessary to give our attention to the middle layer. In the median part, it is solely connective tissue with a row of longitudinal muscle fibers. The connective tissue and the muscle are continuous in the septum. On the sides, right and left of the median line, is a slight projection that makes up the deep nervous system. The muscle fibrils and connective tissue have disappeared. The thickness is filled entirely with longitudinal nerve fibers, containing some nerve cells. The epithelium of the radial sinus is found there as elsewhere, but its cells, instead of being simply cuboidal, extend a short filament that crosses the fibers and seems to be lost in their midst (perhaps it attaches to the thin connective tissue compartment that separates the epidermal system from the deep system). These deep cells, probably of mesodermal origin, thus take the characteristic form of the ectodermal epithelium of the radial band. I think they similarly are important as ganglionic cells.

All along the arms, the internal surface of the radial band has two longitudinal masses and nerve cells. These masses remain separated by the connective tissue-musclar part and I have seen no communication between them. I have found them in all the species I have studied. Their 
presence thus quite probably is general. In young Echinaster sepositus, these masses are very narrow and bordered by nerve cells.

Near the level of each tube foot, each nerve mass has a covering of fibrils (pl. XXVI, fig. 20) that at first follows the contour of the radial sinus and then goes into the axis of the arm. This covering, of variable size, is covered by the epithelium of the radial sinces whose cells are extended for the most part in a fine filament that is lost in the midst of the fibrils. As soon as the nerve is buried in the arms, its fibrils dissociate and it is impossible to follow them in sections. They are probably distributed to the motor muscles, ampullae, etc.

Let us now examine sections of the oral ring (plate XXV, fig. 22). The projection formed by the epidermal neural ring, also covers an annular cavity, the oral sinus, separated into two by a septum. It is glandular in Asterias, simply connective tissue in the others. The nerve ring is composed as in the arms of a thick neuro-epithelial layer, a thin connective tissue wall and finally the ciliated epithelium of the oral sinus. On the distal side (in relation to the central axis of the asteroid), the connective tissue layer contains a mass of circular fibrils, having the same relation with the epithelium of the sinus as in the arms. I cannot say if this mass exists all around the ring. It is especially clear in the interradius. In the interradius of the deep ring is a covering of nerve fibrils that is buried in the connective tissue of the peribuccal skeleton. As in the arms, the fibrils dissociate as soon as they enter the tissue and become impossible to follow. However, I have seen them sometimes go to the large interradial muscle that they probably innervate.

The deep nerve ring is very clear in Astropecten squamatus and Asterias glacialis. In the latter species is likewise another nerve mass that perhaps is not very constant in the class. From the proximal side in relation to the axis, the underlying connective wall to the ectodermal ring contains a second mass of fibrils, smaller than the preceding. I have seen nerves go to the connective tissuemuscular wall of the esophagus.

Enterocoelic nervous system. - A strong muscular cord is found on the aboral side of each arm that gives off branches in all directions that go to the body wall. The role of these cords is very complex. I believe they act especially as angtagonists to the longitudinal muscles that connect the ambulacral pieces. All these muscular cords converge towards the center of the aboral surface thus forming a star with five branches.

A section of the body wall in these regions (pl. XXV, fig. 23) shows the muscular bands covered on the internal surface by a not very thick layer $(40 \mu$ in Asterias glacialis), formed of a nerve center and the peritoneal epithelium. The nervous part is made up of fibrils directed in the same direction as the muscle fibers and contains a very large quantity of nerve cells. The peritoneal cells, aligned in a single very regular layer, extends to the deep part in a thin filament that crosses the fibrillar layer perpendicularly and attaches to the underlying connective tissue. The histological makeup of this system is thus identical to that of the epidermal system, except the ectodermal cells of the latter are replaced by enterocoelic cells.

In summary, this peritoneal nervous center forms a kind of star with five branches whose orientation and path are similar to those of the muscle bands. When the peritoneal muscles are seen in sections of the body wall, it is certain a nerve layer will be found above running between the filaments of the enterocoelic epithelium. From place to place are very clearly seen packets of filaments and connective tissue fibrils that cross the nerve band and extend between the muscular bundles. On the borders of the muscle bands, the fibrillar layer decreases in thickness little by little. The covering epithelium is continuous without a line of demarcation with the ciliated paving cells that cover the entire iinternal surface of the coelom. 
I have found the enterocoelic nervous system in all the species I have examined, Asterias glacialis and tenuispina, Echinastersepositus and Astropecten aurantiacus, but this is the first time I have the most demonstrative preparations. I have not been able to show its presence in Asterina gibbosa. Its small size makes it difficult to do such delicate studies. I believe that there is no communication between the enterocoelic and the superficial intraepithelial plexus that goes between the ectodermal cells.

$\S$ In summary, the nervous system of asteroids has three parts (see figure of the arm, pl.XXV, fig. 24). $1^{\circ}$ An epidermal part whose fibrils are found in all the external epithelium and nearly all the intestinal epithelium. $2^{\circ}$ A deep part forming two longitudinal masses in each radius and one or two circular masses in the oral ring. The nerves coming from this deep mass separate as soon as they enter the tissues. $3^{\circ}$ A peritoneal system on the aboral surface found opposite the first two that apparently forms a separate center.

What is special about asteroids is that the nerve fibrils are extremely delicate and never form defined nerves. Whereas in ophiuroids, for example, it is possible to follow in sections the smallest nerves up to their end, in asteroids I have never been able to see the innervations of a muscle or any organ. It is probable that all the tissues are covered by a very fine network of fibrils that, instead of uniting into visible nerves reach the organs and muscles on their entire periphery. One is reduced to these hypotheses about the role of the three nervous centers. The first is especially sensory, although very probably it also innervates certain muscles (tube feet, skin, etc.). The second and third systems appear to be only motor, especially in relation to the muscles of the arms and the disc.

History. - Greef (18781), Hoffmann (1874) and Teuscher (1876) made the first descriptions of the nervous system in a recognizable way. However they took the row of nuclei of the long filaform cells as an epithelial layer. Lange (1876) reached completely different conclusions. He described very well the fibrils of the epidermal nerve band as well as the epithelial cells that crossed them (Stabchenepithel). But he did not make them a nervous system. For him, the latter is represented by two cellular plates that are spread out on the internal surface of the band, projecting into the radial sinus and forming a large ganglioin at the level of the eye. An analogous circular mass is found in the oral ring. These ganglionic masses (our deep system) represented for Lange the only nervous sysem. Thus they are often called, justly, Lange's nerves. One can see that the work of Lange made at the same time progress because he discovered new parts and a regression because he denied the epidermal system a nervous quality.

Ludwig (1878), Hamann (1885) and I (1887) have restored to the radial bands and the oral ring their true importance by describing their histology and their connections. But the two German authors, like myself, erroneously considered the masses of Lange as thickenings of the epithelium of the radial sinus without importance. I described this epithelium as formed of ciliated cuboid cells, which was otherwise correct.

Perrier (1886) considererd the epithelium of the radial system and septum as nervous: "Towards the end of the arms, notably in the swelling of the ocular patch, they (the epithelial cells of the sinus) no longer forming a simple epithelial covering, are supported by special transverse trabeculae and are put in relation to the sensitive cells of the pits, usually considered eyes. They are thus certainly nervous cells and the epithelial cells with which they are united across the layer of support that has been considered untl now as the nervous system itself are nerve cells of the epithelium" (144). In 1888 (147) Perrier agreed that the fibrillar layer could be a nerve layer but he still considered the cells bordering the radial sinius as ganglionic cells. One part of the vertical filaments that cross the epidermal fibrillar layer would be in connection with the internal cells and 
the other part with the cells that border the exterior of the nerve band. Perrier ended by saying "I believe thus that Lange was not completely wrong when he described the cellular plates of the wall of the ambulacral cavities as kinds of ganglion" (147, p. 14).

Jickeli (1888) describes the epidermal nervous system as formed of two masses, a ventral cellular one and a dorsal fibrillar one and fell thus into the error of Greeff and Teuscher. The description of the superficial plexus, very difficult to follow in the absence of figures, seems equally erroneous to me. Finally, Jickeli thinks to have discovered the intestinal nervous system, previously described in detail by Hamann and myself. However, he considers Lange's mass as nerves (Lange'schen Nerven) and reports the branches that go to the muscles of the ambulacral pieces.

Hamann (1889), in his work on ophiuroids and crinoids, returns with respect to Lange's mass to his original opinion and declares incidentally "that, in ophiuroids just as in asteroids, the dorsal cellular layer with its fibrils has a nervous nature" (71, p. 360).

We see that the question does not cease being discussed and merits careful rexamination. For the epidermal nervous system, I have only confirmed the results of Ludwig, Hamann and my own. For the deep system, I recognize now with Lange, Jickeli and Hamann, that the fibro-cellular masses are certainly of nervous nature. I have illustrated them and the nerves they emit for the first time. As for the enterocoelic system (described for the first time in 1890, 31), it has until now not been reported by anyone.

\section{NERVOUS SYSTEM OF OPHIIUROIDS}

As in asteroids, the epidermal and deep nervous systems are superimposed in the ring and radial cords, separately simply by a thin membrane. But instead of being superficial, they are embedded in the integument. The row of vertical plates separates them from the outside.

Development. - I have studied the development in Amphiura squamata. While making serial sections of adults, we also sectioned at the same time embryos contained in the bursa. It is not uncommon to find some suitable stages.

In a young Amphiura with a disc $240 \mu$ in diameter, the arms are not yet clearly formed. The buccal water ring has about fifteen tentacles that later form the first five pairs of buccal tube feetl and the terminal tentacles (pl. XXV, fig. 25). The nervous system is already well differentiated and is formed by an oral ring that is invaginated in the center in order to be continuous with the digestive tube. This ectodermal ring is completely superficial as in adult asteroids. The relation with the digestive tube, fixed in them and some ophiuroids is transitory in most of the latter. The radial cords (pl. XXV, fig. 26) are equally superficial, but in the youngest embryos that I have been able to study, we already see the lateral folds that go above the band but still without joining it.

In the cords and the oral ring, the nervous fibrils are well developed the very recognizable. The ectodermal cells, whose nuclei only can be seen, are on the periphery, often forming (in the radial cords) two lateral masses. The nervous system is extended onto the tube feet in the form of an annular cushion filled with nuclei (pl. XXV, fig. 27). It likewise forms around the tube feet a fold of integument. Figure 27 gives is very good illustration of the arrangement.

To arrive near the adult state, it is necessary to study an embryo of twice the diameter $(500 \mu)$. Above the oral ring and the radial cords, the folds of the integument are rejoined to include those of the integument. Between the internal surface of the fold and the former superficial surface of the nerves is found a cavity that is the epineural (or ring) sinus. On the lower surface of the epidermal system are found masses of nuclei that represent the rudiment of the deep nervous 
system. I am led to believe that they are mesodermal but it is quite possible they result from a lateral extension of the ectodermal cells of the nerve centers. This question is difficult to answer in a positive fashion.

Around the tube feet, the same process takes place. The circular fold in figure 27 is fused to the wall of the tube feet in a way that a portion of it, formerly free, is now in the interior of the integument. It is truly the annular mass filled with nuclei that I have described before. It is now found surrounded by a cavity derived from the exterior (pl. XXVI, fig.36) and usually in communication with the epineural sinus.

In summary, we see that at a certain moment the epidermal nervous system is completely comparable to that of asteroids. It is in fact superficial and is directly continuous with the esophagous and the tube foot epithelium. Then, by a process that resembles more an epiboly than an invagination, the integumentary folds are formed above the ring, the radial cords and the basal part of the tube foot and encloses them in the tissues, enclosing a small portion of the external surrounding that forms the system of epineural cavities. It is possible that in some Paleozoic ophiuroids (Protaster, Eugaster, Taniaster, Ptilonaster), the nervous system is superficially like that of asteroids. In fact, the tube feet pieces do not appear to be covered on the oral surface by ventral plates.

Relation to the digestive tube. -At its beginning, the nerve ring is always continuous with the esophagus (fixed stage in the asteroids). I have found it in young Ophiothrix fragilis with a disc 2 $\mathrm{mm}$ in diameter. This relation is nearly absolutely conserved in Amphiiura squamata and Ophiactis virens, as Simoroth has illustrated for this last species (169). In large species (Ophiothrix fragilis, Ophiocoma scolopendrina and Ophioglypha lacertosa), it is almost completely the same.The esophagus (pl. XXV,fig. 28) is inserted onto the peribuccal pieces nearly in contact with the ring but without direct continuous contact with it except in the places where nerve fibers are detached to innervate the digestive tube. This arrangement is stil more accentuated in euryalids (Astrophyton clavatum). As I have illustrated (29, pl. V, fig.3), the esophageal epithelium is clearly continuous with dentary pieces.

Most authors, notably Kæhler and Hamann, have misconstructed these relations that I first indicated the morphological importance (1888).

Epineural sinus. - The epineural sinus, whose development I have studied, are well defined in ophiuiroids with the exception of Ophiactis virens, in which they are nearly completely obliterated (pl. XXIX, fig. 59). The epineural ring is often separated from the exterior only by a very thin septum (Amphiura squamata).

The epineural sinuses is not covered by an epithelium. They are simply limited by connective tissue. Sometimes their cavity is crossed by small connective tissue tracts attaching to the surface of the nerve bands (Astrophyton, Ophiocoma, Ophioglypha lacertosa). The tube feet are surrounded at their base by a circular cavity (fig. 36) that is also, as we have seen, only a portion of the external environment. The tube feet ganglia project into this cavity in the form of a semicircle. In some sections, a connection is visible between the epineural sinus and the periambulacral cavity (Astrophyton, etc.) but most often I believe the connection is interrupted.

The epineural sinus system is completed closed and never connects with the coelom nor with the schizocoelic sinus, as Kæhlelr and Hamman incorrectly described. This is easily seen when their mode of formation is followed.

Histology of the nerve centers. In a cross section of the radial band (pl. XXVI, fig. 35 and 36), we see in the upper part a layer of cells arranged nearly symmetrical in relation to the medial plane and often have a free space in the middle. The rest of the band is filled with longitudinal nerve 
fibers. I showed in 1888 (29) that these cells have the general form of epithelial nerve cells, i.e., they extend in a thin filament that crosses the fibrillar layer to go to attach to the conjunctive wall. But these filaments are so thin that they generally are not seen in sections, at least in special preparations. I have recognized them very clearly in Ophiothrix fragilis, Ophiocoma scolopendrina, Ophioglypha albida and lacertosa. Hamann (1889) has revived this question without referring to my work. For him, the peripheral nuclei are true ganglionic cells (some large, some small). I do not deny there are some in the mass of nuclei. But certainly the great majority of them correspond to epithelial nerve cells as in other echinoderms. The distinction of the two types of cells is not the same deeper. There is only a kind of nucleus in most species (Amphiura, Ophiactis, Ophioglypha).

The makeup of the nerve ring is nearly identical (pl. XXV, fig. 28). The nuclei are more abundant near the esophagus than at the distal edge as shown very clearly by Hamann (71, plate 14, fig. 3 and 4).

The epidermal ring is double on the internal surface by the deep nervous sytem, forming a not very thick ring with equally circular fibrils with numerous nuclei on the free surface and in its midst. The deep ring is much thicker in the interradial zones than in the radius (pl. XXV, fig. 28). We shall soon see the nerves emitted by the two nervous systems.

The radial bands are likewise doubled by a layer of the deep nervous system, likewise with longitudinal fibrils containing many cells that are truly typical ganglionic cells. It is formed of two lateral masses separated in the midline by a radial lacuna (pl. XXVI, fig. 35) that do not visibly communicate. They are very projecting between the tube feet and become thinner and reduced nearly to a layer of nuclei at the level of these latter (fig. 36).

The plates of the deep system are separated from the epidermal system, ring and radial bands by a very thin structureless membrane that seems to be perfectly continuous without any visible connection between the two systems. The deep system is important solely as a motor center as seen by the nerves it produces.

History. - The nerve centers have been described more or less exactly by dissection or section by numerous authors, Joh. Müller, Baudelot, Teuscher, Apostolidès, etc. Lange (1876) did not consider this ensemble as a nervous system. For him, the latter is made up of two ganglionic tracts united by transverse commissures that are found on the deep or dorsal surface of the nerve bnds. Except from the commissures, which do not really exist, our deep system is recognized there (Lange'schen Nerven of authors). Simroth (1876), Ludwig (1878), Kæhler (1887) and myself (1888) have given the epidermal system its true importance, sometimes not recognizing the deep system, considered as a simple connective tissue without importance. Perrier (1888) had some doubts on this point of view. Jickeli and Hamann (1889) have in their turn clearly considered these deep masses as nerves. The latter author perfectly described them in the ring and the radial bands and except for some divergence in detail, especially from the histological point of view, my description completely agrees with his.

DESCRIPTION OF THE NERVES. The distribution of the nerves is extremely complex. I want first to enumerate those that leave the oral ring, then succinctly describe the path of each of them and return to the ensemble in two schemes, fig. 29 and 30. The first represents a vertical section of the interradius, passing a little to the side of the medial interradial plane. The second has been constituted after serial transverse sections, verified with care from horizontal and longitudinal sections.

A. Nerves of the oral ring. - The oral ring emits: $1^{\circ}$ a variable number of nerves to the digestive tube (only from the epidermal ring). $2^{\circ}$ five pairs of nerves that go to the peribuccal 
pieces, dentary and interradial muscles and to the nearby organs (mixed nerves formed of the two epidermal and deep layers, $3^{\circ}$. five pairs of nerves for the first ten buccal tube feet (internal or inferior) also from the epidermal ring.

$1^{\circ}$ Nerves of the digestive tube (pl. XXV, fig. 28). - The nerves the epidermal ring sends to the digestive tube are also found in the radius and the interradial zones (according to Hamman, there are ten of them. There certainly are many more in Ophiocoma scolopendrina). They are formed of packets of fibrils with some nerve cells that are located in the connective tissue of the intestine in contact with the epithelium. In sections are found on nearly all the surface of the digestive tube small nerve branches resulting from their ramification (Ophiothrix, Ophiocoma, Ophioglypha, Astrophyton, etc.). Consequently there is no intraepithelial network. In Ophiocoma (pl. XXV, fig. 29), it gives off digestive nerves with small branches that innervate the mesenteric chambers.

I described and illustrated for the first time (1888) the esophageal nerves in Astrophyton clavatum. Hamann and Jickeli (1889) simply reported them in ophiuroids without describing their path.

$2^{\circ}$ Interradial nerves (pl. XXV, fig. 29). - There is a pair in each interradius. Each of them comes chiefly from the deep part of the ring. I believe I have confirmed that their epidermal part also has fibrils but in small number. Each of the large interradial nerves divides when it leaves the ring. A large, very short branch goes to the interradial muscle (interradialis aboralis of Simroth, 169). Sometime it goes into it immediately and sometimes it extends on it for a more or less great distance. In Ophiocoma scolopendrina, this muscle nerve also innervates the diverticula of the bursa included in the muscle. To do this, it gives off numerous small branches strewn with nerve cells that are lost in the wall of the diverticula.

The second part of the interradial nerve has a very complicated path. It isdivided into a great number of branches that innervate the dentary muscles (musc. interrdialis adoralis superior) and the teeth, the muscles of the buccal region (musc. interradialis adoralis inferior), part of the external epithelium, etc. These branches often form a nerve plexus but never have ganglionic swellings as Hamann wrongly showed (71).

The paired dental muscles each receive a nerve branch. The unpaired interradial muscles (abooral interradial and lower adoral interradialis) each receive two nerves.

I described in 1888 the interradial nerves and their endings in ophiuroids and an euryalid. Hamann confirmed my description in the principal points. Jickeli (1889) spoke also about these nerves but his descriptions are incomprehensible in the absence of figures.

$3^{\circ}$ Nerves of the first buccal tube feet (pl. XXVI, fig.30). - These nerves are detached from the epidermal ring, all near the radial band. One could almost say that they belong to the origin of the latter. They are very short, because the origin is tangential to the nerve ring, and ganglion. At the point of contact with the tube feet, the nerve increases greatly in size and forms a nearly complete ganglionic ring around its base. This ring is surrounded by a small epinerual cavity. It gives off a fibrilar nerve that is placed in the connective tissue layer and goes along the tube foot nearly to its end.

According to Ludwig (1880), the nerves of the first radial tube feet are separated from the radial band. I believe with Hamann that it more correct to consider them as coming from the oral ring, so much the more because they are the only tube foot nerves that are not accompanied by a peripheral nerve. Hamann apparently did not see the ganglionic nerve ring at the base of the tube foot that I described in 1888. 
B. Nerves of the radial band. - The distribution of the nerves in the arm, already complex themselves, becomes even more so in the portion of the radius enclosed in the disc. We shall first study the nerves of a segment of the free part of the arm. They are very regularly followed, always in the same order, by muscle nerves, tube foot nerves and peripheral nerves. The latter two are joined from the beginning.

$1^{\circ}$ Muscle nerves (pl. XXVI, fig. 35). - These nerves are separated from the deep nerve layer, formed as is known of two longitudinal masses separated by the radial lacuna. These two masses, in the interval between two successive ambulacra, are very swollen and filled with nerve cells. At the level of the latter they are, to the contrary, reduced to their most simple expression (pl. XXVI, fig.36). From each of these swollen masses leaves a large fibrilar nerve, strewn with nerve cells, that crosses the radial sinus and buries itself in the discoidal ossicle. There it divides into two or three branches that all end in the motor muscles of the arm. All the nerves of the left side innervate the left muscles and those of the right, the right muscles. It is known that in crawling movements of the animal, the right and left muscles are antagonistic.

Teuscher (1876) appears to have been the first to report these muscle nerves (surmised by J. Müller), although very incompletely in an Ophiolepsis. Lange (1876) described them in Ophioglypha lacertosa as having a ganglionic system (deep nervous layer), which is perfectly correct. The commissure that he shows between two mucle nerves of the same pair does not really exist. These are either variable connective tissue bundles or trails of coagulations that unify the two nerves in passing belowthe radial lacuna. Ludwig (1880) and Kæhler (1887) also speak incidently of muscle nerves, without give details of their path. In 1888, I described their mode of termination and their connections. But I have not seen how they leave the deep nerve masses. I was equally incorrect when I reported two pairs of them in some ossicles of Ophiocoma. There is only one of them in all ophiuroids that have been studied. Hamann (1889) has confirmed the description of Lange on the subject of their actual origina. His descriptions on the path of these nerves $(71$, plate 12 , fig. $1,2,3)$ are completely different than mine. If my investigations are more general than his, I think that the German author has taken some connective tissue bundles for nerve branches. The brief description of Jickeli (1889) does not seem to accord either with mine or with that of Hamann.

$2^{\circ}$ Tube foot and peripheral nerves (plate XXVI, fig.36). - If we continue the series of sections, after having left the muscle nerves, we reach the area of a tube foot. The radial band (only the epidermal portion) gives off nerves so closely connected that I did not recognize their duality in 1888. The very thick, single peripheral nerves with some included nerve cells is applied to the wall of the tube foot (the side turned towards the center of the animal) turn there and enter into the calcareous wall of the arms. It is divided into a large number of small branches. Some turn again, innervating the integument of the oral surface of the arms. The others descend into the aboral wall. Their mode of ending is different in the species with spines (Ophiothrix, Ophiocoma, Ophiactis, Amphiura) and those with smooth arms (Ophioglypha, Ophioderma, Astrophyton). In the first case, the small nerves are directed towards the spines, where they innervate the muscles and the rod after swelling into a small ovoid ganglion (pl. XXVI, fig.36). In the second case, the peripheral nerves do not have a ganglionic swelling. Their fibrils are dissociated and probably end in contact with the integument (pl. XXVI, fig. 34). The mode of division of these nerves varies greatly according to species. But I cannot give details, which are of minimal interest.

The tube foot nerve is much smaller at its origin than the peripheral nerve. It is ganglionic, i.e., covered with the same cells as the radial band. Joined to the preceding nerve and surrounded by an epineural sinus, it comes in contact with the tube foot. From this ring leaves on the internal 
border, the true tentacular nerve, fibrillar everywhere, that enters into the connective tissue wall of the tube foot to contact the epithelial covering. We have seen in development that this ganglionic demi-ring (pl. XXV, fig. 27) is originally exterior. Because of the formation of folds, it has been embedded into the tissues surrounded by a small epineural cavity.

C. Nerves of theportion of the arm enclosed in the disc. - The distribution of nerves in this part is extremely complicated and variable from one species toanother. They can be studied only by serial transverse sections. Figures 30, 31 and 32 of plate XXVI have been prepared by this means. To best understand the relations, it is necessary to describe in some detail the arrangement of the skeleton and the muscles. The portion of the arms that is enclosed in the disc contains a variable number of ossicles and consequently of tube feet (3 in Ophioglypha albida, 6 in Ophioglypha lacertosa, 4 in Ophiothrix fragilis, Ophiocoma scolopendrina, etc.). On each side of the arm is found the slit that gives access to the bursa. All along the slit, between it and the arms, is a raised calcareous projection that becomes more and more prominent according to its distance from the mouth and that to the confines of the disc. It ends by rejoining the aboral wall and is fused with it (pl. XXVI, fig. 33, pi). The figures make this arrangement very clear. All along the length of this calcareous band is a large nerve, lateral nerve, to which end all the peripheral nerves of this region of the arm.

The first muscle of the arm is unpaired, the superior radialis muscle of Simroth. Thus the fibers are transverse in relation to the longitudinal axis of thearm. It is found nearly at the level of the second buccal tube feet in contact with the water canal. The other muscles are paired and their fibers are parallel to the axis of the arm.

We begin with Ophioglypha albida, which presents the simplest arrangement: $1^{\circ}$ the nerves of the first buccal tube feet are detached from the ring, close to the point where it produces the radial nerve; $2^{\circ}$ the radial nerve emits a pair of nerves for the superior radialis muscle (leaving from the deep nervous layer); $3^{\circ}$ the peripheral and ambulacaral nerves of the second buccal tube feet. The peripheral nerves give from their origin two branches that innervate the oral surface of the arms. It then continues its path around the tube foot and, in being curved the length of the bursal slit, marks the beginning of the lateral nerve. $4^{\circ}$ A pair of nerves for the muscles of the arm. $5^{\circ}$ Peripheral and tube foot nerves of the third pair of tube feet. The peripheral nerve gives as before two small nerves going toward the oral surface. It mingles at its end with the lateral nerves. $6^{\circ} \mathrm{A}$ pair of muscle nerves. $7^{\circ}$ The peripheral and tube foot nerves of the fourth pair of tube feet. The peripheral nerve goes to join the lateral nerve. But at this point the calcareous oband that runs along the bursal slit rejoins the aboral wall of the disc. The lateral nerve passes into the aboral integument and forms the peripheral plexus of the body wall as is shown in figure 32 .

The lateral nerve of each side, from its orgin, gives off an interradial nerve that extends to the interradial muscle, and contributes a major part of the inervation of the integuments of the oral surface (compare with fig. 29).

All these nerves lack ganglia. They are formed of fibrils containing a large number of nerve cells.

In Ophiothrix fragilis (pl. XXVI, fig. 31, the arrangement is a little more complex. $1^{\circ}$ Nerves of the first buccal tube feet. $2^{\circ}$ Nerves of the superior radial muscle. $3^{\circ}$ Peripheral and tube foot nerves of the second buccal tube feet. I do not believe these peripheral nerves go to join the lateral nerve. They appear to me to end in the integument. $4^{\circ} \mathrm{A}$ pair of nerves leaving the epidermal layer is carried directly towards the bursal slit to end in the lateral nerve (bursal nerves of Luidwig. I call them Ludwig's nerves). $5^{\circ}$ Muscle nerves, etc. are as in the figure. The peripheral plelxus of the aboral surface of the disc has the same formation. 
The arrangements in Ophiocoma scolopendrina are nearly the same as in Ophiothrix.

The maximum complexity is found in Ophioglypha lacertos (pl. XXVI, fig. 30). $1^{\circ}$ Nerves of the first buccal tube feet. $2^{\circ}$ Nerves of the superior radial muscle, $3^{\circ}$ Peripheral and tube foot nerves of the second buccal tube feet. The peripheral nerves clearly make up the lateral nerve of each side, which gives off as always the interradial nerve. $4^{\circ}$ The large Ludwig's nerves that go to join the lateral nerve. $5^{\circ}$ A pair of very small nerves that go to innervate the integument of the oral surface of the arms (integumentary nerves) that does not exist in the other species. $6^{\circ}$ Muscle nerves. $7^{\circ}$ Peripheral and tube foot nerves of the third tube feet. $8^{\circ}$ Integumentary nerves. $9^{\circ}$ Muscle nerves, etc., etc. The peripheral plexus of the aboral surface of the disc has the same constitution. In Ophioglypha lacertosa, as in Oph. albida, each peripheral nerve gives from its origin a small branch that innervates the integument of the oral surface of the arm (as in fig. 34).

It is necessary to emphasize that are not nerves for the bursae in the true sense of the word. In fact, the slit is innervated by small branches from either Ludwig's nerve or the lateral nerve, or even nearby integumentary and peripheral nerves.

GENITAL NERVOUS SYSTEM. - It finally remains to speak of the genital nervous sytem that we also find in echinoids. We know the path of the aboral vascular ring shown by Ludwig in his classic figure (107, plate xv, fig. 12). In an interradius, this ring is continuous with the axial gland. And it is on it, the length of the arms, that are implanted the gonads. If a transverse section is made of it at a point of its path (pl. XXVI, fig. 66), a very large cavity is seen. On its wall is attached a projecting cord filled with cells that is the genital cord. Usually opposite from the point where the cord is attached is a small projection. Careful examination shows it is of nervous nature. This genital nerve includes, in addition to fibrils, a very large number of nerve cells, especially peripheral nerves. I have followed the entire path of the aboral ring in Ophiocoma scolopendrina, Ophioglypha lacertosa, albida, Ophiothrix fragilis, etc. (in figures 30, 31 and 32, it is represented by a line of small dashes).Coming to an end, it emits fibrils that are very difficult to follow that innervate the surrounding muscle bundles and, without doubt, the gonads also although I have not been able to see fibrils going to them.

It is probable that this genital ring is an automous center that is capable of producing reflexes. However, it connects with the general nervous system. In each interradius, recall that we have reported two interradial nerves coming from the lateral nerves of two adjacent arms and extending to the base of the interradial muscle. I have seen very clearly in Ophiothrix fragilis, at the point where the vascular ring extends equally to the muscle, that the interradial nerve is anastomosed with the genital nervous ring. Perhaps it even terminates at this point.

Another connection that I am less certain of is the communication between the genital nervous system and the lateral nerve. At the point where the aboral ring passes into the arm and the periphery of the disc, I have often seen, but not with sufficient clarity for me to confirm, a communication established between the nerve ring and the lateral nerve of each side of the arms.

History. - The only authors who have been concerned with the description of the nerves are Ludwig, Hamann and Jickeli. For Ludwig, I have mentioned only the nerve that he believed to go to the bursae that I have called Ludwig's nerve. The descriptions of Jickeli (1889) and Hamann (1889) refer only to the free part of the arms are completely different from mine, especially for Ophioglypha albida. I cannot give a detailed critique that would be tedious. Jickeli has described much more of the nervous system than there is. He has taken coagulations or connective tissue tracts for nerves. Hamann has confirmed my description of the peripheral nerve of Ophiothrix fragilis (1888). There are some details that it appears he has seen clearly, with many others with 
which we disagree completely. I shall recall that he studied only one species while my results are from several types.

\section{NERVOUS SYSTEM OF ECHINOIDS}

As in ophiuroids, the radial cords and oral ring of the epidermal nervous system are embedded in the underlying tissues, but by a process probably a little different. The more exterior nervous system has never been observed or the process of invagination followed in young urchins. However, there is no doubt that it occurred.

Radial bands. - If the edge of the radial band of an asteroid is recurved above until it is united on a median line, there would be a tube enclosed in the tissues of which the internal or inferior wall would be formed by the radial band, the upper wall by a much thinner epithelium. Thus the cavity would be a portion of the external environment. This is the condition that is nearly completely fixed in Dorocidaris papillata. In fact, as Prouho has very clearly shown, the radial band is raised on its edges in decreasing thickness to continue by a kind of flat covering forming the external wall of the tube (151). The enclosed space is the intra-nerve space of Prouho. We prefer to call it epineural because, in fact, the nerve elements are contained in the band and do not extend very far into the raised border. There is surely no trace of it in the external wall.

In the other regular urchins (Sphaechinus, Strongylocentrotus, Echinus, etc.), the arrangement is nearly similar (pl. XXVII, fig. 38), although less clear than in Dorocidaris. The radial band is raised on its edges, but the epithelium soon becomes so indistinct at the upper part that it is not possible to distinguish the connective tissue wall of the tube.

In clypeasteroids and spatangoids the nerve band has a similar plan and resembles completely that of ophiuroids or holothuroids. The epinieural sinus is always well defined.

At their aboral end, the radial bands merge with the ectodermal epithelium of the body. As in ophiuroids and asteroids, this is the point where the terminal tentacle is found, passing through the pore called ocular. At the same time that the radial water canal is extended, the nerve cord accompanied by epineural sinus also goes through the pore or ocular notch. The cord merges with the thickened ectoderm. The water canal and the epineural sinus end in a cecum in contact wit the thickening (pl. XXVII, fig. 42). In arbaciids (pl. XXVII, fig. 43) the radial cord is bifurcated at its aboral end. Each branch ends at the external epithelium (see section on terminal tentacles).

On the oral side, as is known, the radial cords go into oral ring. The epineural sinus forms likewise above the nerve ring, but with the cavity extremely reduced and nearly absent in places. The radial epineural sinuses are not completely free from the epineural ring. It is known, in fact, that when an injection is made into their interior, the dye is stopped at the level of the auricles and does not go further. It is only by ruptures that it escapes into the general cavity, as Kohler said. At the place where the nerve cord passes under the peristomial membrane, it is applied to the test in such a way that the lumen of the epineural sinus is obliterated to reappear immediately after. In gnathosome urchins, the oral ring keeps its embryonic connections with the esophagous. In fact, it is continued on all its periphery by a very thin membrane with the esophageal epithelium on one side and the buccal lip on the other. The figure shows this arrangement well that, according to Prouho, is still clearer in Dorocidaris. At the points where the ring sends nerves to the esophagous, the communication is then quite evident. It is even impossible (Sphorechinus granularis) to say where the esophageal epithelium begins and where the nerve epithelium ends. At this point, if the 
buccal lip is not attached to the edge of the nerve ring, the epineural annular sinus opens to the exterior.

In spatangoids (pl. XXVIII, fig. 54), to the contrary, the nerve ring is very elongated (especially on the side) of the esophagous and the original connection has completely disappeared in the adult. The ring is covered by an annular cavity (epineural ring) that Hamann clearly recognized and which is especially clear on the side where the pentagonal nerve is very close to the esophagous.

Nerves produced by the epidermal system. - The oral ring sends numerous fibrils to the digestive tube. Although I have not been able to determine the exact number of these nerves, I can however say that they especially border the radii (one or two per radius). Longitudinal packets of fibrils leaving the circular fibrils of the ring pass into the esophageal epithelium. It is easy to discover them in dissociations with osmic acid and distilled water. Between the filaments of the cells of the digestive tube appears a more or less thick layer of fibrils (approximately 1/10 of the thickness) exactly as in the intestine of asteroids. This nerve plexus can be follow in the entire pharynx and in the beginning of the first curve. But soon after it decreases in thickness and is no longer detectable in sections or dissociations. Hamman has clearly recognized this system and gives good figures for this esophageal region (69, plate 112, fig. 6). To the contrary, in the figures of the intestine that show bundles cut crosswise, it appears evident to me that they are migratory cells (muriform corpuscles) that he has taken for packets of nerve fibrils (pl. 12, fig. 7; pl. 13, fig $6,69)$. Packets of fibrils likewise leave to oral ring to innervate the lip. I have seen them especially clearly in a clypeasteroid Echinodoiscus biforis.

In spatangoids, the arrangement is a little different. All around the edge of the oral ring leave a certain number of fibrilar nerves (shown by Lovén after a dissection) that ran in the chamber the covers the ring and the esophagus and soon entered into the connective tissue wall of the digestive tube. The nerves divide and form a very complicated plexus in the connective tissue layer as in ophiuroids. Very clear in the esophageal part, the nerves disappear little by little as they follow the digestsive tube. Hamann has completely described them and I only confirm his results (69).

Tube foot and peripheral nerves (pl. XXVII, fig. 38). - All along the radial bands are detached nerves destined for the tube feet and the periphery of the test as in the ophiuroids. To study them, it is necessary to make serial sections perpendicular to the radius. An extension from the radial nerve at each tube foot while keeping its structure forms the tube foot nerve that has, consequently, the quality of a ganglionic nerve. The radial band is folded back above slightly to be continuous with the upper covering of the epineural sinus. It is from this lateral fold that leave, to the right and left, the peripheral nerves. They are closely associated with the tube foot nerve so that a cross section shows a kind of tube, a virtual cavity, of which half will be formed by the tube foot nerve and the other half by the peripheral nerve. It is necessary only to glance at the figure to understand how the cells are placed in the central part of the ensemble formed by these two nerves. The tube foot nerve, after having crossed the test, enters into the epithelial layer of the tube foot and continues to the end.The peripheral nerve, arriving under the under the external epithelium, expands into a large sheet into which penetrates the epithelial filiaments whose fibrils contribute to the formation of the peripheral intraepithelial plexus. Sometimes (aboral surface of Strongylocentrotus lividus) there is a small free space, opening outside, that separates the tube foot and peripheral nerves at their terminal part, as if an invagination was formerly produced at this point.

This description fits perfectly the regulars and clypeasteroids I have studied. In spantagnoids (Spatangus purpureus) there is a small difference. The peripheral nerve and the tube foot nerve are separated one after the other from the radial band, not simultaneously, one from the upper fold 
and the other from the band as in the regulars. The peripheral nerve, especially fibrilar, is spread under the epithelium in a very visible nerve sheet whose fibrils soon passs into the cells. The ganglionic tube foot nerve passes into the pithelial layer of the tube foot.

Deep nervous system. - The deep nervous system is found only in gnathostome urchins. It consists of five fibro-cellular plates located in the radii, part on the ring and part on the radial bands at the point where they detach from the ring. These five very large plates are not joined to each other however, at least in a visible fashion. They are separated by a thin connective tissue compartment. Numerous ganglionic cells, probably of mesodermal origin, cover the free surface. These five masses are related to the innervations of the muscles of the masticatory apparatus. Iin fact, a large fibril nerve is comes from each side and descends along the edges of each jaw and gives off fibrils that probably innervate the motor nerves (pl. XXVII, fig. 37).

The deep plates, only motor, and their nerves exist in all gnathostomes that I have studied (regulars and clypasteroids). They are completely absent in spatangoids because they have no trace of jaws. They have not been seen until now. In fact, as Prouho has remarked, the nerve fibers that Valentin, Fredericq and Kæhler have describe as leading to the jaws are instead only ligament cords.

History. - Prouho (1888) has described very well in Dorocidaris papillata the path of the nerve network. It even appears that in this species the tube formed by the two peripheral and tube foot nerves have a true cavity, not potential. Hamann (1887) has not seen in echinoids the separation of the two nerves. He described them mixed into a single mass with central cells. The separation of the tube foot and peripheral nerves has however some importance, because we will find it in holothuroids and ophiuroids. How they end, to the contrary, has been well illustrated by the German author.

In spatangoids, Hamann has described well the peripheral plexus and the path of the tube foot nerve. But he has not understood well the relations of the tube foot and peripheral nerves, whose arrangement is not greatly different from those of regular urchins (the peripheral nerve is separated more clearly from the tube foot nerve). The Hautnerv, described by Hamann as going directly from the radial cord to the skin is probably our peripheral nerve.

Histology. - In all urchins, the central parts of the nervous sytem have the same construction. They are formed by a tall epithelium of ecotdermal orgin and nerve fibers. The epithelial cells are enlarged and their external end and even have a thin cuticle. The nuclei enclosed in protoplasm are found in the extreme portion thus simulating a peripheral layer of nerve cells. The cell body is reduced to a long, thin filament that attaches to the connective tissue layer that limits the band on the internal side. The nerve fibers, longitudinal in the radial bands and circircular in the oral ring, mixed with some bipolar never cells are extended to enter the epithelial filaments up to contact with the nuclei. Finally, the inner surface of nerve cords, except in certain places where the deep nerve plates are found, have a thin connective tissue layer and the epithelial lining of the radial sinus (pl. XXVII, fig. 38).

Most authors (Hoffman, Teuscher, Fredreicq, Kæhler, Prouho) have taken the epithelial nuclei as cells of the external layer. Hamann (69) interpreted them most exactly. As he said correctly, the nuclei with the long filaments (seen by Prouho) are ectodermal cells like those of asteroids.

GENITAL NERVOUS SYSTEM. - This ensemble probably must be referred to the deep nervous system of enterocoelic origin (like the enterocoelic system of asteroids). It is formed by a ring, located on the aboral surface, tangential to the five gonopores. It is always located at the periphery of the annular sinus of the aboral surface (a sinus of enterocoelic origin whose relations and significance we shall examine later), forming a slight projection to its internal wall (see pl. XXX, 
fig. 69 and 72, and in 151). In Echinodiscus biforis, its thickness is ca. $20 \mu$. At the level of each gonad, it emits a short branch that goes to the gonopore where it enters the test (pl. XXX, pl. 69). From the histological point of view, this ring is formed of ciricular fibrilar nerves with a simple layer of nerve cells at the surface. This ring is thus gnaglionic and perhaps acts as a center, i.e., the seat of reflexes.

The genital nerve ring was discovered by Prouho (151) in Echinus acutus and Strongylocenntrotous lividus. According to this author, it is missing in Dorocidaris papillata, without being able to see what can replace it. I can confirm the results of Prouho for this species. I have also found it in Arbacia pustulosa and a clypeasteroid, Echinodiscus biforis. It is probable that it exists in the great majority of urchins. I have not been able to see it in Echinocyamus pusillus, but it should be so small in this species that it would be necessary to make extremely delicate investigations to reveal it. To my great regret, I have not been able to investigate it in spatangoids.

There is one point that I cannot accept without reserve the views of Prouho. According to him, the genital ring would be connected to the ends of the five radial cords, which would thus make it only an emanation. The figure of Prouho is not very instructive (151, pl. XVI, fig. 2). I have investigated this connection with care and I have not been able to find it in any species. Moreover, the ring is so separated from the end of the radial cords in Echinodiscus that it is difficult to accept a connection between them. For me, the genital nerve ring is an isolated center that is self sufficient and does not connect directly to the centers of epidermal origin. However, the thing is so difficult to prove that I do not pretend to reject positively the assertion of Prouho. It is a point that, to be completely clarified, requires new investigations.

\section{Nervous System of Crinoids}

In crinoids, the epidermal nervous system is reduced to its simplest expression (Greeff, Teuscher, Ludwig), while the deep system, that all authors agree is of mesodermal origin, aquires an extraordinary development (W. Carpenter, Semper, H. Carpenter, Jickeli).

Epidermal nervous system. - The g grooves are filled with a layer of epithelial-nervous tissue, identical to that of asteroids. Between the filamentous bases of the epidermal cells are found longitudinal nerve fibrils (Ludwig, Hamann, Peerrier, Carpenter, etc.). This epithelial-nervous layer covers the entire length of the tentacles as well as the intertentacular lappets, but no further. The rest of the skin lacks a definite epidermis. The five ambulacral cords merge around the mouth with circular fibrils located as always between the cells of the buccal epithelium and from which leave the intraepithelial fibrils going to the digestive tube,. They are especially abundant in the esophageal region. This buccal ring, well illustrated by Ludwig, H. Carpenter, Perrier in various crinoids, represents the epidermal ring of asteroids or, that which is the same thing, the oral nerve ring of urchins, holothuroids and ophiuroids. This homology, doubted by some authors (notably Jickeli and Carl Vogt and Yung) does not appear disputable. Up to here, the homologies with the other echinoderms are perfectly maintained. This system is ony rarely atrophied in some places, for example in the pinnules of Antedon accela and angusticalyx, as well in some arms of Actinometra magnifica that lack grooves.

It must be noted that crinoids have no trace of the deep system adjacent to the epidermal system that is so developed in asteroids and ophiuroids. 
Enterocoelic nervous system. - The deep nervous system, whose enterocoelic origin is certain, is considerably developed. I have no intention of describing it. I refer for that to the memoirs of Ludwig, who described it well, although not having recognized its nature) (97), H. Carpenter (21), Jickeli (82), Perrier (145) and Hamann (71). It is certainly of enterocoellic origin, like the aboral centers of asteroids, ophiuroids and urchins. H. Carpenter says (1884) that the axial cords of neocrinoids are at first in contact with the enterocoelic epithelium in the paleocrinoids with imperforated radials (transitory stage in the pentacrinoid larva of Antedon). Perrier (1886) has very clearly confirmed the fact for the axial cords of the arms and pinnules. This is first the cellular mass in contact with the enterocoelic epithelium and very probably results from the proliferation of the latter. Then they are isolated little by little by sinking into the underlying calcareous tissue. Moreover, the central part of the system, the nerve cup located at the apex, has kept its original connections with the enterocoel. In fact, the nerve tissue is in direct contact with the epithelium of the chambered organ, that is known to be an appendage of the enterocoel (Perrier, Hamann, Bury).

The axial cords are very llike those in the peritoneum of asteroids. If a transverse section is made of an arm of an asteroid and of an arm of Antedon, the exact same elements are found, i.e., beginning with the oral surface: $1^{\circ}$ an ectodermal nerve band continuous with the epithelium of the tube foot and in asteroids, also with the ectodermal covering of the body; $2^{\circ}$ a radial schizocoelic cavity that is well developed and crossed by a septum in the asteroid and more reduced but indisputable in the neocrinoids (Antedon, Actinometra, Penacriniius); $3^{\circ}$ the radial water canal; $4^{\circ}$ a vast cavity, an extension of the coelom of the disc, simple in asteroids, divided by septa into three principal cavities in crinoids; $5^{\circ}$ the aboral surface of the body containing muscle fibers and axial nerve cords of enterocoelic origin (see fig. 24, pl. XXV).

It can be seen the analogy is complete and that the deep nervous system of crinoids, that has so greatly intrigued morphologists, is no longer an isolated formation in echinoderms.

Finally, Jickeli has described a third nervous systm whose existence has been confirmed by Hamann and Perrier. It consists of a periesophageal ring, from which leave two nerve branches for each arm, going to the right and left of the water canal. This system, whose development cannot be followed, communicates with the nerves emitted by the axial cord. Perhaps it is necessary to consider it a part of the enterocoelic nervous system. In any case, nothing can be found in other echinoderms that can be compared to it.

\section{NERVOUS SYSTEM OF HOLOTHUROIDS}

The nervous system of holothuroids is now very well known. It is in these animals that were first discovered those distinctive features that were then found in other echinoderms.

The nerve ring and the radial cords derived from the ectoderm (Selenka, Ludwig, etc.) are so sunken into the underlying tissues that they reach the internal body wall. The nerve ring has lost all connection with the esophageal epithelium as in spatangoids. Moreover, it is by its external face in direct contact with the surrounding tissue, i.e., that it there is no epineural ring. The five radial bands, to the contrary, are separated from the body wall by a free space (Semper, Greeff, Hamann, Carl Vogt and Yung, etc.), the extra-neural space of Hérouard, that terminates in a caecum at the two ends of the band. As the process by which the nervous system, initially in contact with the ectoderm, passes to the interior of the integument has not been followed. It is impossible to know if this epineural sinus represents, as in ophiuroids and echinoids, cavities of invagination, 
portions of the exterior environment, or schizocoelic spaces developed afterwards. As for me, I will lean toward this latter interpretation, based mainly on the fact that there is no epineural cavity below the neural ring. The epineural sinus gives off small divertidcula, often accompanying the lateral nerves (tube foot and peripheral nerves) for a part of their path (pl. XXVII, fig. 39, $s n^{\prime}$ ).

The oral ring is formed entirely by the epidermal system. The radial cords, to the contrary, are double their entire length by a deep nervous system, separated from the external layer by a connective tissue wall (interlocular partition of Semper, Teuscher, Semon, Hérouard). The histology is identical to that of other echinoderms. The centers are formed by an epithelium with superficial nuclei between the cellular filaments that run the nerve fibrils. Hamann insists correctly on the homology that exists between the "Deckepithel" and the epithelium of the superifical water cord of asteroids. Like Semon, I think that these cells with an epithelial form play the role of ganglionic cells, all the more because they are identical on the internal surface of the deep nerve layer and in the tube foot nerves (pl. XXVII, fig. 39).

At their lower end (Cucumaria) the radial cord is reduced to the epidermal layer and enters into the integument and fuse with the ectoderm of the body wall. They are accompanied by an extension of the epineural sinus that ends in a caecum in contact with the extermal epithelium and by the radial water canal (pl. XXVII, fig. 11). These five formations must be interpreted as the vestige of terminal tentacles, like those that exist in the other echinoderms.

Nerves. - The oral ring gives off a variable number of branches to the digestive tube. These fibrilar nerves produce small branches to the epithelium of the buccal area (Semper, Hamann). The nerves ramify into the connectiave tissue layer of the intestine where they are found in great number, especially in the esophageal portion.

It is the same for the nerve ring that leave the ganglionic nerves of the peribuccal tentacles.

The two layers (epidermal and deep) of the radial cords innervate the integument and tube feet: it leaves from the ganglionic nerves (for the tube feet) and fibrilar-cellular nerves (peripheral) that form a complicated plexus in the skin (Müller, Semper, Teuscher, Jourdan, Hamann, Semon). An interesting point to iinvestigatte is the exact origin of these branches on which there is little agreement. According to Semper (1868), except for the different interpretations, the tube foot nerves leave from the external layer (epidermal), those from the body wall from the internal or deep layer. Semon (1883) said that the nerves of the skin come from tube foot nerves, which is certainly not correct (Die Nerven für die Haut warden von den Füsschennerven als ganz feine Zweige abgegeben, 163, p. 592). Hamann (1884), in a schematic figure where the deep layer is not found, shows the peripheral nerves leaving from the epidermal layer. Hérouard recognizes that the two layers of the radial cord, but above all the external layer, contribute to the formation of the amblacral nerves. As for the peripheral nerves, "it is especially the interanl band that seems to contribution most for their formation" (78, p.101).

I have tried in my turn to clarify this question by very thin transverse sections. Although the origins of the nerves are very difficult to see well, I do not know why, I think I have obtained definitive results (pl. XXXVII, fig. 39): the tube foot nerves are certainly extensions of the external epithelial layer, whose fibrils and cells are continuous without interruption into the nerve. The internal or deep layer, is not involved in their formation.

The nerves of the peripheral plexus come from the two layers. The epithelial cells of the covering are not continuous with them, which contains only sparse cells in the fibrils. The section I show in fig. 39 is a little oblique and by happy chance passes through the origin of two kinds of nerves. The peripheral nerve to the right, a little after formation, gives off a branch that goes to inervate the layer of circular muscular fibers. 
According to Hérouard (73), the deep nerve band "is ended above by two symmetrical nerve sheaves whose ends are lost in the longitudinal muscle bundles (p. 82).

The nervous system of elasipods (except the statocysts) are exactly like normal holothurodis (Théel, 180): the nerve rings gives the tube feet nerves and digestive nerves. The radial cords give off ambulacaral nerves and numerous peripheral branches.

\section{NERVOUS SYSTEM OF SYNAPTIDS}

Development. - Semon (165) describes the nerve ring of the embryo of Synapta as formed by a differentiation of the buccal ectoderm (Mundeingang, Mundschild). The radial bands and even the tentacular nerves appear also to come from the deep surface of the ectoderm of the body. There is no stage where they are freely exterior as in the preceding echinoderms. These different formations are little by little separated from the surface by the interposition of mesodermal cells: they are sunken into the tissue until they occupy the place where they are found in the adults. In this very simple process, a kind of delamination that closely approaches they which we know in mollusks, arthropods, etc., there are no cavities of invagination. In addition, the epineural sinus is completely lacking in synaptids.

Anatomy. - The nervous systems are completely like those of holothuroids. An oral ring, located within the calcareous ring and five radial bands. There is no epineural cavity, the contact with the tissues is direct. As in holothuroids, the oral ring has no direct communication with the esophageal epithelium.

The deep nervous system doubles the radial cords nearly their entire length (Hamann, Semon): the deep layer begins a little beyond the statocysts and ends below about the same time as theradial muscle. At their inferior end, the five radial bands, reduced to their epidermal layer, enters into the integument and fuses with the ectodermial epithelium of the cloaca (pl. XXVII, fig. 40). There is no special formation at this point. It is simply the vestige of the primitively superficial situation of the nerve centers or, if one prefers, this is the point where the delamination that separates the radial cords from the superficial ectoderm stops.

The histology of the epidermal and deep systems is identical to that we have described for holothuroids (see expecially Hamann, 67).

The oral ring emits to the buccal tentacles twelve ganglionic nerves, covered with an external layer of cells whose very clear fibrillary extensions perpendicularly cross the nerve (seen by Hamann) (pl. XXVII, fig. 45). A variable number of fibrilar nerves also go to the digestive tube. They are found in large number in the connective tissue layer. Going from the ring to the mouth (pl. XXVIII, fig. 5 2), these nerves give off some small branches to the epithelium of the buccal area (reported by Hamann).

The radial bands, from their origin (still without the deep layer), give a pair of nerves to the statocysts (pl. XXVIII, fig. 48). These nerves leave from the most internal part of the band and have only one fiber. For the remainder of their length, the bands provide peripheral nerves that appear to me to depend on both the epidermal and deep layrs, although I not been able to observe with certainty their mode of origin (Hamann represents them as coming solely from the external layer). Barely formed, they ramify greatly and form a complicated peripheral network with small superficial ganglia (Semper, Hamann) that also innervate the muscular zones. 
The deep layer of the radial bands end insensibly above and below by decreasing in thickness. Like Hamann, I have not been able to recognize in Synapta an upper end analogous to that described in holothuroids by Hérouard (73)

\section{PHYLOGENY OF THE NERVOUS SYSTEM}

The result of the study we just made is that all echinoderms have primitively a superficial nervous system as it is found in asteroids and crinoids. In four groups, probably for protection, the nerve centers are in the interior of the tissues, more are less guarding the primitive cnnections (ophiuroids, echinoids, holothuroids and symaptids). This emigration of the nervous centers is produced independently in each group by slightly different processes. In urchins, it is a well characterized invagination, producing a tube whose internal wall alone contains the nerve elements (especially Dorocidaris). In ophiuroids, it is instead a kind of epiboly, the calcareous plates bordering the nerve bands moving towards to medial line in a manner to cover them like a roof. Finally, in synaptids and perhaps holothuroids, the nerve centers are separated from the ectoderm by a kind of delamination.

The separation of the nervous system into two layers, one epidermal, the other deep, also appears to be produced secondarily and in an independent manner because the nerves they give off do not correspond from one group to another. So the peripheral nerves that, in asteroids, ophiuroids and echinoids come only from the epidermal system, come in part from the deep layer in holothuoroids and from a completely differ system in crinoids. We can relate all the facts together in supposing that the ancesters of different groups had nerve centers, first superficial, as we have proven, and without a trace of division, that give off all the necessary nerves (tube foot, peripheral, and muscular). Then, in each group, a deep part of othese centers is separated by a thin wall from the principal part and is mostly differentiated as a motor center.

There is no trace of a enterocoelic nervous system in synpatids and holothurodis, while it is well developed in crinnoids, echinoids, ophiuroids and asteroids. Is it really homologous in these four groups as certainly is the ectodermal system of the oral surface? In other words, has it been inherited from one group to the other or is it the result of independent formation? Documentation to resolve the question is lacking. The fact that the genital nerve ring is absent in Dorocidaris papilla (Prouho) is for the moment the strongest objection that can be made for the first opinion. However the differences of position are such that the second hypothesis seems to me most reasonable.

\section{TERMINAL TENTACLES}

The history of the terminal tentacles formed at the end of the radial water canals is most instructive, especially from the phylogenetic point of view.

We begin with the asteroids that have kept the ancestral characters nearly intact. We know that in the young, the first five buds formed by the water ring constitue the five radial canals. These buds themselves continually give off the tube feet to the right and left, but always remain one at their end producing a terminal tentacle.

The disk has at this moment two concentric rows of calcareous plates. The most external, placed radially (terminal plates) extend to the end of the arms and come to be placed below the 
terminal tenticles that they more or less completely surround to better protect them. In addition to the terminal plate, the tentacle is surrounded by a circle of very mobile small spines that lower on it at the least touch and cover it completely. Regenerating arms always have a terminal tentacle as soon as the bud begins to appear at the surface of the broken part.

Histology. - The constitution of the tentacle is easy to describe. It is an extension of the water canal, covered by the radial nerve band. Moreover, we know that the ocular cups pile up in the form of a bright red spot at the base of each tentacle.

A section of the tentacle from inside out shows: the epithelium, a layer of longitudinal muscle fibers, a very thin connective tissue zone, and finally a tall external epithelium enclosing a thick nerve layer. This epithelium is formed of non-glandular cells (Sinneszellen, according to Hamann) that are attachd to one side to the conjunctive zone. The other side has a cuticle with long cilia. I refer to my work on asteroids (28) for details.

OPHIUROIDS. - In ophiuroids, development is roughtly similar. The very short terminal tentacle is protected as in asteroids by a terminal plate that, in general, surrounds it like a ring and to which it can be retracted in case of attack. The terminal plates are placed primitively on the disk around the radial plates and carried to the end of the arm as they develop (Fewkes, Bury, Ludwig, etc.).

As is known, there is no ocular spot at the base of the tentacle that is, except for this, is identical to that of as asteroids. As in the latter, its epithelial-nervous covering is formed by the extension of the radial band. I do not see why Hamann said that the nerve cord gives a basal ganglion to the tentacle (71, page 256).

At this point, the nervous system, invaginated into the tissues, becomes exterior as it is completely in asteroids. As for the epineural sinus, it naturlly at stops at the base of the tentacle that marks the limit of invagination. The sinus is moreover very reduced is is scarcely separate ed from the external medium.

Euryales. - In euryales with bifurcdated arms that are then divided into numerous small branches, one can no longer find terminal tentacles, there are none at the end of the branches (Astrophyton). They surely exist at the beginning of development and are probably found at the point of bifurcation of the five primitive arms as in Antedon, but I have not been able to find any trace of them in the adult.

ECHINOIDS. - In young urchins, when they have just separated from the pluteus, the future terminal tentacles are very evident and are even the principal means of locomotion. Called primordial tentacles, all embryologists have figured or described them (Joh. Müller, Krohn, Lovén, A. Agassiz, Bury, Colton and Garman) in the young of Arbacia, Strongylocentrotus, Goniocidaris, Echinus etc. Between them and the mouth are soon formed ten tube feet arranged in pairs that become the locomotory organs. The primordial tentacles at first located on the oral surface are little by little moved toward the aboral surface as the consequence of the formation of new tube feet. Their size remains the same or increases very little while that of the other organs rapidly increases. This explains why Krohon believed he saw absorption and disappearance. In the young specimen of Hemiaster cavernosus Phil., figured by Lovén (188, pl. 14, fig. 164, measuring 2.3 $\mathrm{mm}$ ) the five terminal tentacles are still very projecting and even larger than the adjacent tube feet. This stage is fixed perfectly in the adult Echinocyamus pusillus.

During this time, the calcareous plates of the calyx are developed: one dorso-central at the apex, a row of interradial plates (basals) and a row of radial plates. The migration of the terminal tentacles is stopped by the latter that sometimes shrink to shelter the tentacle like the terminal plates of asteroids, sometimes completely surrounding it. The tentacle passes through a pore or 
less accentuated pore that always turns toward the oral pole near the end. Because of this connection, it seems to me indisputable that the radial plates are quite homologous to the terminal plates of asterois and ophiuroids, contrary to the opinion of H. Carpenter and P. Sladen. I thus give the name of terminals (radials of Lovén, ocellars of Agassiz; pseudo-oculars, Perrier; intergenitals, Hamann; parapicals, Munier-Chalmas; neurals, Seunes). I will come back to this important question of homology in regard to the phylogeny of the skeleton.

The location of the terminal tentacle is easily recognized in dry specimens or fossils by the perforation or notch of the terminal plates (inappropriately called the ocellar pore and that would more appropriately be called tentacle pore or terminal pore).

In most species, the pore is near the oral edge of the plate. In some, however, the primitive facies is kept and the pore is outside the plate that is slighted sunken to receive it or protruding below the pore. The best exmple to cite is certainly Micropedina Cotteaui Coquand (from the Cenomanien) of which a good figure is found in the Paléontologie française of Cotteau. Likewise, in the genus Goniopygus, in Leiosoma Meridanense (Cotteau (Turonien), Acrosalenia patella, Desor, Heterosalenia Martini Cotteau, Salenia, Peltastes, Acropeltis, Glypticus, Micropyga, etc., the pores are, oif not outside the plate, at least as the extreme edige of them and the ambulacral plates. According to the cousins Sarasin, in Asthenosoma urens, which has kept so many of its echionthurid ancestral characters, the terminal tentacles are not always completely surrounded by the ocellar plates.

Histology. - To understand well the constitution of the terminal tentacle, it is necessary to recognize that this is also the point of the termination of the invagination of the radial nervous system. The latter resumes its primitive ectodermal connections. The cavity of invagination, on the other hand, must open outside, at least virtually. It can be studied either by radial sections or perpendicular sections at the radius.

At the level of the terminal plate, the radial nerve band, slightly folded into a groove, receives the water canal in its concavity. The cavity of the radial sinus is completely obliterated at this point. To the contrary, the epineural sinus persists but is divided into two parts separated by the central protorusion of the nerve band (Strongylocentrotus lividus). Then everything straightens vertically and gos into the plate until it contacts that exterior epithelium (pl. XXVII, fig. 42).

The nerve band goes to fuse completely with the ectoderm that froms at the point a rounded proection that is easily seen in the sections. The epithelium is naturally greatly thickend all around the pore.It contains a thick layer of nerve fibrils. The epithelial filaments that become lost in the fibrillary mass of the nerve are seen very clearly. As for the epineural sinus that is divided into one or two cavities, it is separated from the external environment from which it derives, as we have previously shown, only by the thickness of the epithelial layer. The water canal, always lined by a ciliated epithelium, occupies the central part of the epithelial projection that represents the last vestige of the terminal tentacle. It often has at its base, where it enters into the plate, a very large dilation.

In all the urchins that I have studied, regulars and clypasteroids, the terminal tentacle has this description. As one can expect, it is more projecting in young than in adults. In Echinocyamus pusillus (pl. XXVII, fig.12), it is much more developed than usual and constitutes no more a simple mamelon, but a true tentacle is shown in the figure. This species has moreover kept the embryonic character.

In some urchins, evidently because of a secondary arrangement, the terminal tentacles have two pores corresponding to the tentacles. This is the case of Arbaciades and some palechinids (Melonites multipora, Palaechinus elegans). I have studied this arrangement by means of sections 
in Arbacia pustulosa (pl. XXVII, fig. 43.). When we look at the plate by the internal surface, one sees only one orifice. But in the thickness of the latter, the canal that in part is bifurcated and opens with two small exterior pores, placed in very deep depresions, separated by a very thick calcareous spur. The nerve band, accompanied as always by the epineural sinus and the radial water canal, is engaged in the canal, then at the point of bifurcation is divided into two like the water canal. As for the epineural sinus, it is obliterated and disappears. Each branch of the nerve ends at the exterior epithelium with which it merges. This latter is extremely thick and filled with black pigment (as the rest of the test of Arbacia). The nerve fibrils are continuous with the peripheral plexus of the test, as usual. Each branch of the water canal ends also at the place of a small, very deep cup-like cavity.

This curious arrangement is evidently secondary, because numerous authors have observed the embryos of Arbacia (Joh. Müller, Agassiz, Colton and Garma) and have certainly perfectly described the five priordial tentacles. It is probably later in the course of development that a calcareous spur divides the termal pore into two separate parts to form two openings that are found in adults. There is moreover in some types, notably Spatangus, Echinocardium etc., an analogous arrangement but much less complete. The terminal pore has on its aboral edge a spur that incompletely divides its cavity in giving it nearly the form of a $\mathrm{U}$.

The presence of two pores was reported for the first time by Lovén in Arbacia nigra (1874, 117). Then A. Agassiz (1880), Duncan and Sladen (1885) showed that these terminal pores (called "optic pores" by the latter authors, 43) were present in all species of Arbacia and in fossil and recent species of Caelopleurus, also in the family Arbaciadae. As for the third genus of the family, Podocidaris (represented in the Crecaceous by the probably synonymous genera Magnosia and Codiopsis), the authors do not give information on the subject. One can see clearly in the figures of Agassiz (3, pl. 34, fig. 15) three pores on each terminal plate of Podocidaris prionigera. Is the arrangement still more complex in this genus.

Among the Paleozoic urchins, Melonites multipora Norw. (according to Römer) and Palaechinus elegans M'Coy (according to Baily) also have two terminal pores per plate. One sees that it is not always necessary to consider characters present in the most ancient types as primitive as done by most. It is very curious to see that Melonites and Palaechinus, which date from the Upper Silurien and Carboniferouss, have exactly a secondary character of adaptation, which already presupposes a long evolution.

Lovén (118) has not seen ocellar pores in the curious Tiarechinus princeps Laube (Triassic carbonate of Saint-Cassían) that has other aberrant characters.

History. - The terminal pores have always caught the attention of anatomists and it is very curious to see, after twenty one years of indecision, that one returns in a probably definitive way to the first hypotheses proposed.

Valentin believed in the existence of an ocular spot at this level, the origin of the term ocellar plate, still used today by most authors. A. Agassiz (1874) did not accept the existence of an eye. Relying mainly on embryological data, he compares the pores to terminal tentacles of asteroids. Really, there is not a projecting tentacle in the adult as Perrier (1875) noted. But the opinion of Agassiz is none-the-less perfectly correct. It has not been adopted in general by the authors that have followed. Lovén, Duncan and Salen, Prouho, etc. have continued to speak of optical or ocellar pores without being able to recognize the least trace of visual organs. Finally, H. Carpenter and Sladen, based on their work and that of Ludwlig, have homologized the so-called ocellar plates no longer as terminals of asteroids and ophiuroids as Lovén but as radials of these types, that always remain on the disk at the origin of the arms $(20,23,172)$. 
Prouho (1888) showed in different urchins (Dorocidaris, Echinus, Strongylocentrotus) the radial bands pass through the terminal pores and go to merge with the overlying epithelium. He has well described the gutter of the nerve band, but he does not speak of the extension of the epineural sinus to the skin.

Hamann, nearly at the same time, describes the terminal pores in the same way (Echinus, Sphoechinus, Centrostephanus, Strongylocentrotus). He has seen the projecting epithelium, the fusion of the nerve with the ectoderm, but he apparently attached no importance to the extension of the epineural sinus. For Hamann: "The dome-like extension of the sensory epithelium of the intergenital places of echinoids is homologus to the end of the tentacle with the ocular patch of asteroids, but this is not, as Agassiz thinks, the same tentacle" (69, p. 125).

For us, as seen in the previous section, the opinion of Agassiz is perfectly correct. It is certainly the terminal tentacle that goes through the plate. It is very reduced in most types, still well defined in Echinocyamus pusillus. In conclusion, the distinction of Hamann is more subtil than real. This close homology between the terminal tentacles of asteroids, ophiuroids and echinoids evidently includes the plates that protect them, contrary to the current prevailing opinion. Bury, in his nice embryological studies (17), without knowing the anatomical works on the subject, is also brought to believe that the ocular represents well the terminals and that the true radials (which remain on the disk of asteroids and ophiuroids) are not developed in urchins.

Crinoids. - Terminal tentacles are present in crinoids, but only at the stage where they are pentaradial echinoderms. The very young pentacrinoid of Antedon rosacea, before the arms are formed, has as is known twenty five peribuccal tentacles: five groups of two arranged in festoons of the disk between the five primitive triads. When the arms begin to appear, in the form of a slight protrusion, the median tentacle of each of the five triads constitutes the radial water canal of the arms as in normal groups. All the other tentacles remain on the disk. The arms, instead of elongating as usual, soon bifurcate to form the ten arms and the numerous piinnles of the adult. The terminal tentacle remains undivided and remains at the point of bifurcation as described by Wyville Thomson (azygous tentacle) and Perrier. Later, it atrtophies and disappears. One can find no trace of it in adults.

There are no terminal tentacles at the ends of the ten arms and pinnules as Perrier (1873) showed. The water canal ends in a caecum even before reaching the end.

It is noted that, like in cystids, there is no special calcareous plates in connection with the terminal tentacles in extant crinoids. In blastoids, however, (Pentremites), the ambulacral fields end in the area of large plates (radials of H. Carpenter) are very generally homologous with ocellars (terminals to us) of urchins. The ambulacral pores of blastoids are not known very well. Nor has a terminal pore at the end of the ambulacral field been seen, so that this homology does not seem absolutely demonstrated to me.

HolOTHUROIDS. - All authors who have studied the development of holothuroids (Joh. Müller, Krohn, Kowalevsky, Selenka, Danielssen and Koren, Ludwig etc.) do not refer at all to terminal tentacles. At no moment, it seems, do the ends of the water canals project outside as in urchins, ophiuroids, asteroids and crinoids. Perhaps it will be necessary to resume studies on younger larvae because in adults there are indisputable traces of these organs.

The terminal tentacles of adult holothuroids are nearly identical to those of urchins. I have studied them in Cucumaria cucumis and Lacazii. The tentacles form a small circle around the anal opening, but they cannot be detected from the outside. It is necessary to make sections of the terminal part of the body (pl. XXVII, fig. 41.) The radial nerve, the water canal and the epineural sinus cross the thickness of the integument to reach the epidermis. As in urchins, the radial sinus 
disappears at contact with the body wall. The nerve band, until then composed off two layers (internal and external), is reduced to one (external layer) that also becomes much thinner and fuses with the packets of ectodermal cells that we described in regard to the integument of dendrochirotes. The epineural sinus is very clear and ends in a caecum in contact with the epidermis. Similarly, the water canal, sensibly enlarged, is separated from the exterior only by a very thin layer of nervous tissue. It is certainly probable an organ in process of disappearance, a simple morpohological vestige.

In Thyone, five calcareous plates project around the anus. Hérouard has homlogized them with the terminal plates of urchins. These plates are peculiar to the genus and are lacking in other holothuroids. Certainly they can be compared to pieces as constant as the terminals of urchins. It would be no less interesting to investigate the relations of the calcaroues pieces and the terminal tentacles.

I have also studied it by serial sections of Holothuria impatiens. To my great surprise, I have not found terminal tentacles. The tube foot nerve, the radial and epineural sinuses end very abruptly in contact with the internal wall at the same time as the radial muscle, without crossing the integument. Is it the general case in aspidochirotes that, more evolved than the dendrochirotes, have completely lost the already very reduced vestigeof the terminal tentacle. Not having studied an example, I cannot say. It would be appropriate to resume studies on this subject as well as in molpadids in which we do not know the path and constitution of the radial water canals.

The five "kurzen, etwas ästigen Papillen" figured by Semper (168) around the cloacal opening of Haplodactoyla morpadioides (anal papillae of Ludwig) are probably terminal tentacles that project more than in the other holothuroids.

SYNAPTIDS. - In synaptids, which do not have radial tube feet, contrary to the opinion of Metschnikoff, Semon and Hamann, there are naturally no terminal tentacles. The radial nerve alone crosses the bodoy wall and fuses with the ectoderm as I reported above, without having any special formation to report (pl. XXVII, fig. 40).

FUNCTIONS OF THE TERMINAL TENTACLES. - The terminal tentacles are very sensitive, as can be expected given their rich innervations. Aso, they are protected by spines arranged in a way to cover them with the least disturbance (asteroids, ophiuroids, urchins). But their role as tactile sensory organs should be very restricted in view of the slight projection above the test.

Perhaps they have a special sensory function (olfactory?), although this has not been demonstrated. Those of urchins and holothuroids should be considered, I think, as simple morphological remnants without special functions.

\section{STATOCYSTS}

Statocysts are found only in two well defined groups: synaptids (Apneumona of Semper) and some elasipods.

Synaptids. - In Synapata inharens, I can only confirm the nice studies of Semon on young synaptids (164). The statocysts or "Baur'schen Bläschen" the name of the scientist who studied them in the adult (1864) are in five pairs. There is a statocyst on each side of the radial nerve, very near the nerve ring and calcareous crown. They can be studied by either radial or perpendicular sections at the radius. The latter are preferable to study the nerve as Semon described very exactly. 
Statocysts (pl. XXVIII, fig. 48) are hollow spheres about a micron in diameter, completely embedded in the connective tissue of the body wall. They are covered with a squamous epithelium of very small cells that Semon described as having small ciliated cells. The statocysts have a large number of spherical otoliths, well described by Semon, formed of a refringent mineral material. Each otolith is a vesicular cell with a parietal nucleus and a very thin layer of protoplasm. The mineral content (calcareous?) remains obscure in polarized light (figures in Semon, (164; Ludwig, 114; pl. XXVIII, fig. 51).

At the level of the statocysts, the nerve band is formed of only one layer. The supplementary internal part begins a little further. A small nerve from the deep part of the band goes to each statocyst. This very short nerve is on the wall, spreads slightly and disappears. It is formed of fibrils with some nerve cells, but is not ganglionic. This shows the statocysts transmit sensations but are not the seat of reflexes.

It is known the statocysts appear very early in the embryos (the tononeau or pupe stage) where J. Müller (1852) recognized them and very well described under the name "Bläschen mid Doppelkornen" 21 .

In the family of synaptids, statocysts are known in various species of the genus Synapta. Ludwig reported then in Chiridota rotifer $(1881,108)$ and Semon in Chiridota venusta $(1887,164)$ from the Mediterranean, also to the number ten. Danielssen and Koren described them (36), but lacking otoliths (?), in Myriotrochus Rinkii Steenstrup and Acanthotrochus mirabilis Dan. and Kor.

Elasipods. - I have studied them in Elpidia glacialis, there they had been discovered and well described by Théel; (179). There are 14 in this type. There is one on the two radii of the bivium $(\mathrm{C}$ and $\mathrm{D})$ and six on each lateral radius of the trivium (B and $\mathrm{E}$ ). Radius $\mathrm{A}$ lacks them. The statocysts of radii $C$ and $D$ are much larger and near the nerve ringe. Those of radii $B$ and $E$ are smaller, one at the level of each lateral foot. It is impossible to study them by sections. It is necessary to remove the spicular layer. The very thin peritoneal connective tissue wall is thus isolated and allows examination by transparency with the usual stains (pl. XXVIII, fig. 49).

The statocyst is in complete contact against the nerve band so thre is no defined nerve. As in synaptids, it is lined internally with a squamous epithelium with very small cells. It contains five to 20 otoliths. Each otolith (pl. XXVIII, fig. 50) is an elongated ovoid cell filled with concentric mineral layers that Théel though was calcium phosphate. The nucleus is at one end of the ovoid in a notch in the mineral layer. All is covered with a very fine membrane.

The presence of multiple statocysts seems to be localized at this time in the family Elpidida. In Elpidia incerta, Peniagone vitrea and affinis, there are a large number all along radii B and E (Théel, 180). In Paraelpidia elongata, there are statocysts containing thirty to thirty-five statocysts all around the nerve ring (Théel). In Kolga Nana Théel, the radial nerves of radii B and E each have about thirty vesicles containing twenty otoliths. Kolga hyalina Danielssen and Koren also have a larger number of statocysts, approximately fifty-six. There is a pair on each radius of the bivium $C$ and $D$. Each nerve of the trivium $B$ and $E$ has twenty-six vesicles, a greater number than the lateral feet. As in Elpidia, the median A of the trivium lacks them. Each statocyst contains twenty to thirty otoliths (see figure of Danielssen and Koren, 36, tab. III).

We will consider the functions after the study of sphaeridia.

\footnotetext{
${ }^{21}$ Semon though that the statocysts of synaptids came from five invaginations of the buccal ectodoermm. Each of these invaginations then separated into two to form the two statocysts of each radius. However, as he was not able to follow the complete development, there assertions must be confirmed.
} 


\section{SPHAERIDIA.}

Sphaeridia are small organs particular to the echinoids, discovered and named by Lovén (117). Up to now, there is no plausible reason classify them as sensory organs. The sphaerida of the primitive types are less richly innervated than the spines or pedicellariae. But when they are well differentiated, as in cypeasteroids, it is quite evident they are organs of special sensititivity.

Sphaeridia are completely lacking in cidaroids. Duncan has reported them in Salenia profundi Dunc. $(1877)^{22}$ fairly similar to those of other urchins examined from this point of view. They are always in the radial zones near the peristome (Lovén). They appear to be lacking in echinothurids.

In echinids, diadematids, echinometrids, there are numerous sphaeridia, either beside the tube foot pores (Astropyga) or separated from them by a row of large spine mamelons. Their number can be very large in adult specimens. I have counted more than one hundred in an adult Echinus acutus (for the five radii combined).

In Arbacia, there is a single sphaeridium in each radius in a depression very near the peristomial border. In Ceelopleurua in the same family, there are four five pairs per radius as in echinids (Agassiz).

In the Pourtesiæ and spatangoids (Spatangous, Echinocardium, Brissus, Brissopsis, Schizaster, etc., the sphaeridea are placed as the base of the tentacles of the buccal area in shallow depressions, one to three and even more in each depression. Likewise in Echinoneus (cassidulids) there is a sphaeridium in a shallow cavity near the pores.

The depression can become very deep and transformed into a cavity, closed or not, in which is found a single spheridium, always occupying the same positon: the animal in its natural position, i.e., with the oral side down, the spheridium is attached on the upper, internal angle of the cavity, meaning it is pendant. I know no exceptions to this rule that authors until now have not reported. The sphaeridia thus defined exist in most cassiduloids (one on each of the five first peristomial plates) and in a large number of clypeasteroids (one per radius on the first peristomial plate) in a cavity communicating by a narrow canal with the outside. In Clypeaster, Arachnoïdes (according to Lovén), Echinocyamus, Echinodiscus biforsis, Peronella orbicularis, there is only one sphaeridial cavity for each radius, but this time entirely closed (containing two sphaeridia in Clypeaster and Arachlnoïdes, one in the others).

I can only refer to the numerous and magnificent figures of Lovén (117) that show very exactly most of the facts mentioned here.

Development. - Lovén has follow development of sphaeridia in some regular echinoids. At the beginning, there is always only one per radius (fixed stage in Arbacia and as for the number in Echinocyamus, Echinodiscus, Peronella). Then the number increases, more of less according to species. The sphaeridia enclosed in the closed cavities (clypeasteroids) are first exterior. The borders of the depresseion of insertion are gradually raised and end in the sphaeridial cavity.

Histology. - The histology of sphaeridia have been studied histologically by Lovén (1874), Ayers (1886) and Hamann (1887) that do not agree at all in some important points. Other than regulars and Spatangus purpureus, I will direct my attention to the clypasteroids, neglected until now, in which the sphaeridia attain a high degree of differentiation.

Sphaeridia have the form of a more or less small elongated mass. A half millimeter in length. The basal part that is articulated to a small mamelon of the integument that is formed of a

${ }^{22}$ Duncan. On the Salenidae Wright, Ann. Mag. Hist., vol. 20, 1877, p. 70. 
reticulated calcareous tissue, as all other calcified parts of urchins. The mass, to the contrary, is constituted of concentric layers of extremely birefringent vitreous calcite. It is crossed in all directions by a system of canaliculi containing an organic framework with basal cells. When decalcified, there remains only the limiting membrane and the ramified organic framework whose branches reach the periphery (this is what Lovén believed to be the reticulated calcite. Ayers (6) has given a good documentation of this. If the sphaeridia are treated with potash, which dissolves the organic material, washed and mounted in dry balsam, the network is filled with air and appears clearly, especially the peripheral openings of the canaliculi that are hidden in fresh material by the epithelium that covers them.

The sphaeridia are very mobile on the articulating mamelon, to which they are scarcely attached by the organic framework and small connective tissues tracts. In addition, these organs are easily detached in dry specimens. Hamann has described a crown of small muscular fibers in Spatangus purpureus. I have not found them in other species. An epidermis covers the base of the spheridum and the mass. On the mass it is transformed into the flat, squamous, ciliated epithelium, described by all authors (Lovén, Kœhler, Ayers, Hamann, etc.). A plexus of nerve fibrils forms a ring barely or not gangliated that is much less important in appearance than that of the spines. There is no other nervous formation. The ramified nervous tissue in the sphaeridia described by Ayers is nothing other than the organic framework of the vitreous calcilte. The only part that one could consider as sensory is the base of the spheridim. In fact, at the level of the nerve ring, the epithelium is greatly elevated and has long cilia (reported by Hamann in Spatangus purpureus; I have found them in Echinus melo).

In the three clypeasteroids that I have studied (Echinocyamus pusilus, Echinodiscus biforis, Peronella orbicularis), the constitution of the sphearidia is a little more complex. In order to study it well, radial sections are preferable (pl. XXVII, fig. 46). I have previously defined the position of the sphaeridium in its cavity. It is not attached to the wall by any muscle, no more in most of the preceding echinoids. It thus entirely lacks voluntary movement. The sphaeridial cavity and the sphaeridia are covered with a flat epithelium in which are seen only nuclear spaces in sections. But this changes in character around the base of the sphaeridium. It is a kind of ring, formed by numerous, dense, larger cells that rest on a bed of nerve fibrils. A small non-ganglionic nerve goes to this epithelial-nervous layer. I have not seen with certainty its point of origin. It goes to the radial band, to which it probably attaches. In clypeasteroids, the base of the sphaeridium is surrounded by an eminently sensorial zone, corresponding without doubt to the basal nerve rings of Spatangus and Echinus.

Functions of the statocysts and sphaeridia. - For the sphaeridia, Lovén, based on their location near the peristome, thought they could be an olfactory or gustatory organ (an opinion accepted by Agassiz). Ayers, without saying positively, attributed to the sphaeridia the ability to perceive chemical changes in the ambient environment. He said they were insensitive to sound. These hypotheses are inadmissible. They have in fact no relation at all to the distinct structure of the sphaeridia, whose sensoroy zone has no resemblance at all to an olfactory nervous ending. Moreover, in clypeasteroids, as we have seen, the sphaeridia are enclosed in closed cavities without any communication with the exterior. This in incompatible with the functions Lovén and Ayers attributed to them.

Hamann thought the sphaeridia as transformed spines possibly transmitted vibrations from the environment. There may be some truth in this, but it must be noted that such organs would be poorly placed on the oral surface where the water is constantly moved by the movement of the 
tube feet, spines or masticatory apparatus. The sphaeridia are also very large organs to perceive the small vibrations of the surrounding environment.

The distribution of the statocysts and sphaeridia give no very useful information. Statocysts are found in synaptids, apodus animals living in sand at a shallow depth, and in elpidids, animals of a greater depth that have lateral barely movable appendages, a kind of locomotory support. As for the sphaeridia, they are always without exception on the oral suface or the ambulacra in urchins. A sensory ring is found at their base that can respond to their movement or displacement. Statocysts, like sphaeridia, receive very small, non-ganglionic nerves that can only transmit perceived sensations. Their nature remains to be determined.

Delage $^{23}$ has shown in an indisputable way by experiments with some cephalopods, crustaceans, decapods, and schizopods, that statocysts, in addition to the function in perception of vibrations (which is not the same thing as hearing sound, as P. Bonnier correctly noted), plays a very important role as organs of perception of orientation. They inform the animal about its rotational movement, on the position of the medial plane in relation to the vertical and horizontal plane. When they are removed, the animal loses equilibrium. It is necessary to supplement the statocysts with organs of touch or light.

Statocysts of echinoderms, identical to those of mollusks, also probably inform the animals that have them on their orientation and movements of rotation. But it is very difficult to prove it experimentally. As for the sphaeridia, why could they not be organs of the sense of orientation? This accords very well with their constant existence on the ambulacral surface, the particular constitution of the calcite that seems to function to increase their weight, the special arrangement of the sensorial zone, the pendant position of the sphaeridia that allows them to follow like pendulums all the movement of the animal, etc. It would not be difficult to do experiments in this sensd by extirpation like Delage with the statocysts of mollusks and crustceans. Arbacia, which has only five sphaeridia, would be a very appropriate type for experimentation. In this hypothesis, the sphaeridia would give information on the inclination of the equatorial plane to the horizontal plane, on its movements of rotation, etc. It should be noted that Romanes and Ewart (155) have recognized in urchins the existence of a sense of "gravity" based on the precision and facility with which urchins placed on the aboral pole returns to the normal positon. The sphaeridia are not without resemblance to the sensory organs of hydromedusae and ctenophores (imappropriately called statocysts or otoliths). These are also heavy bodies resting on a more or less delicate pedicule, surrounded by neurral endings capable of responding to displacement. Chun ${ }^{24}$ has shown ctenophores that the central sensory organ was the regululator of movement of the cililated palets. I.e., it controls equilibrium like the statocysts of mollusks and crustaceans.

The hypothesis we propose for the sphaeridia is thus corroborated by some convincing facts. But is evidently experimentation that will give the last word.

Sphaeridia are lacking in cidaroids. This absence can be understood only if these organs have disappeared by regression. This regression is very probably in relation to the considerable development of the spines that have taken the locomotry function from the tube feet. Delage has, in fact, shown that the more the more numerous the supports of the body and more developed the organs of touch, the less importance the statocysts have as organs of equilibration. It could be the same for sphaeridia in the ancestors of cidaroids.

\footnotetext{
${ }^{23}$ Delage. Sur une function nouvelle des statocystes, etc. Archiv. Zool. Exp., $2^{e}$ série, t. 5, 1887, p. 1.

${ }^{24}$ CHUN. Die Ctenophoren, Fauna und Flora des Golfes von Neaple, 1880, Leipzig.
} 


\section{NERVE ENDINGS IN THE SKIN}

SYNAPTIDS. - When we examine a piece of the skin of Synapta inhorens, stained only with methyl green, destained with alcohol, a quantity of green patches is noted, relatively large and close to each other. Each of these patches coyresponds to a group of glandular cells. At the center of the group is nearly always a clear patch that we will soon examine. The glandular cells, as I have said, form small masses around this center.We found some in the integument.

Perpendicular sections of the skin gives excellent information (pl. XXIV, fig. 5). The accumulation of these cells produces a small, slightly projecting mamelon above the ordinary epithelium. The glandular cells are large and numerous. They show a finely granular protoplasm and a basal nucleus. In summary, they have all the characters of mucus cells. In their midst and occupying the most projecting point is a group of filiform epihelial cells that must be considered sensory. They are the clear patch that we reported in frontal view. Finally, the entire ensemble passes insensibly on the sides to the ordinay ectodermal epithelium.

The peripheral nerve plexus, located as is known in the thickness of the connective tissue layer and formed of anastomosing fibrillary cords, swells under each glandular mamelon in a large fusiform ganglion. It is richly supplied with nerve cells strongly stained by the dyes. A large fibrilar nerve goes from this ganglion into the central filiform cells where it ends. These are thus certainly sensory.

The glandular-sensory mamelons appear to occur in all species of the genus Synapta and also in Anapta gracilis (Semper) which, as is known, lacks anchors. They are not reported in neighboring types.

History. - The tactile mamelons were first reported by de Quatrefages (1842) who compared them to packets of nematocysts of coelenterates. Semper (1868) carefully described them, but he said nothing about their histological makeup. Finally, Hamann (1884) recognized the presence of glandular elements (Becherzellen et Schlauchdrüsen) and confirmed the existence of ganglia. But his figures are not very exact and very inferior to those of Semper. He notably believed that the gangion was mixed with the glandular mass and did not perceive the nerve it gives off. Petit also consider the organs a glandular mamelons (1884).

Functions. - The tactile mamelons have a very complex composition. The presence of glandular and sensory cells indicate two different functions. The presence of a basal ganglion is evidented related to those of particular reflexes, as for the spines, tentacles, etc.

In addition to their tactile functions that are indicated, I believe the mamelons, like most of the mucus glands of echinoderms are specific defensive organs. de Quatrefages noted a long time ago that the synaptids secrete a product that, following its release, made the sea water foamy. Semon spoke of a mucus permitting the body to disengaage the adherence of the anchors, an assertion I cannot accept. The quantity of mucus (?) secreted is extremely low and I have not been able, in living Synapta inhaerens, to convince myself satisfactorily of the production of this substance. Whatever it is, it is very probable the the product secreted by the cells of the tactile mamelonso plays a role in the protection of the animal, either in case of attack or to decrease harsh contact when the animal crosses sand grains. We should then see in the central sensory cells a warning mechanism and in the basal ganglion the center of the reflex for secretion. The mamelons have no relation with the anchors because they are perfectedly developed in Anapta gracilis Semper, which lack these organelles (Semper). 
HOLOTHUROIDS. - The epidermal endings are very simple. They have been well described in aspidochirotes by Jourdan and Hamann. In these, the peripheral plexus is in the connective tissue wall, divided into very fine branches that end for the most part at the ectoderm. The fibrils, accompanied by a number of more or less large nerve cells, disappears between the epidermal cells that have no special differentiation. There is no intraepithelial layer.

In the dendrochirotes (Cucumaria), the arrangement is a little different. In sections stained in a suitable way with picrocarmine and sufficiently thin (pl. XXIV, fig. 4), is seen a very dilicate fibrilar network that ends at each of the packets of ectodermal cells, as is known, in the conjunctive zone. On the netework is found a large number of nerve cells, but there is no part that one can consider as especially glanglionic. The fiibrils are buried in places between the cells, where it is impossible to follow them. These latter, although buried very deeply in the mesoderm are still in contact with the exterior by their filiform cellular body that ends at the cuticle. They can thus transmit, although weakly, tactile sensations.

CRINOIDS. - Perrier and Hamann have reported numerous nerve endings in the arms, pinnules and disk. The small nerve branches coming from the lateral cords (system of Jickeli) of axial cords (system of W. Carpetner) end simply at the external layer and merge with the superficial cells (figures in Hamann, 71, taf. 20, fig. 9; taf. 21, fig. 10.). On the festoons that border the ambulacral grooves, alternating with the triads of tentacles, there are numerous tactile endings. These are epithelial cells, of normal appearance, connected in groups of five or six, which have stiff and very delicate bristles. These are visible only in fresh preparations (figured in 23, pl. 18, fig. 20). Perrier appears to have seen them in $1873(139$, p. 51) in Antedon rosacea. Möbius has reported similar endings on the pinnules of Antedon Sarsii.

ECHINOIDS. - There are no special terminations to report in the epidermis. The nerves from the radial band going to the integument (pl. XXVII, fig. 38) spread out in a large cover and form a peripheral plexus running between the ectoderm cells described by various authors, Lovén, Pouho, Sarasin, Hamann, etc.The more specialized sensoroy parts are distinguished by the thicknes of the nervous layers (fascioles of spatangoids) but are not seen in epithelial modifications.

For the spines, we hav spoken of the ganglionic ring at their base.

For the pedicellariae, there are epithelial endings perfectly described by Hamann. Some groups of epithelial clls (tactile cushions of Sladen) have stiff cilia and below them the nervous network in a thick fibrillar cover. These sensory cells are dispersed in well defined groups in the interior of the valves and evidently represent the mechanism for sensation. I can only refer to the good figures of Hamann that I have verified for the most part and that are quite correct (69).

OPHIUROIDS. - The endings of the peripheral nerves are very difficult to observe. Their fibrils are dissociated, running on the organic framework of the calcareous pieces and it is nearly impossible to distinguish connective tissue fibrils oriented in the same direction. Hamamn is certainly confusing in some of his figures of nerve endings (71, taf. XIV, fig. 6). However, in favorable cases, the small nerve branches can be followed up to contact with the exterior layer. They spread slightly and their fibrils disappear in the midst of the peripheral cells of the tract (see figures of Hamann, taf. XIV, fig. 5, 7).

For the spines I will recall the existence of a basal ganglion (pl. XXIV, fig. 7). The radial nerve divides into branches and its ramifications go to the periphery where they probably end, but it is impossible to follow them. For the teeth, the ramification of the nerve is identical except it has no basal ganglion.

ASTEROIDS. - As in urchins, the peripheral plexus is formed by fibrils running between the ectodermal cells. It is continuous with the central nervous system that, as I have said, completely 
keeps its ectodermal character. The nervous layer is very thick in the dermal branches, the base of pediceellariae, etc., but there is no special sensory differentiation. According to Hamann, Sinneszellen are found in the integument whose filifom cellular bodies are continuous with the nerve fibrils. These sensitive cells are distinguished by this characer and by their delicateness. For my part, I do not believe in the existence of sensory cells thus defined. The causes of error are so numerous in the dissociations that it is nearly impossible to confirm that such cells are continuous with the nerve fibrils. Moreover, we tends now to believe that there is no continuity between the receptor element and the transmimtting element, but only cotinguity (Ehrlich, Dogiel, Retzius, Mitrofanoff, Fajersztaja, etc.). This is exactly what I support for asteroids. The delicacy of the cells had completely mechanical basis. I have found many times in dissociations some epithelial cells completely identical to the Siinneszellen of Hamann. Moreover, that there are no sensory cells (in the sense of Hamann) in the more differentiated regions, from the nervous point of view, as the tentacles, the eyes, etc. It is useless to remark here that the various authors who were occupied with this question after Hamann also did not find Sinneszellen (Prouho in urchins, Ludwig has proposed Keulen-Stacheln in ophiuroids).

\section{NERVE ENDINGS OF THE TENTACLES AND TUBE FEET}

As a general rule, all tentacles and tube feet depending on the water vascular system receive ganglionic nerves, i.e. covered with a layer of peripheral cells that should be considered nervous, as I have explained in regard to the nervous system. It is difficult to demonstrate the fact for Antedon and asteroids whose tube nervous system remains entirely ectodermal, but it is perfectly evident for synpatids, holothuroids, echinoids and ophiuroids.

SYNAPTIDS. - The only organs to consider are the buccal tentacles that are appendages of the water ring. They have two types of nerve endings: the first of special sensitivity, probably olfactory; the second simply tactile.

Each buccal tentacle, more or les ramified, has on its internal surface (that which is turned towars the mouth) some small knobs (about fifteen) assembled into two longitudinal groups, nearly in the middle of the tentacle. These are organs of special sensitivity (cupules sensitive, Sinnesknospen). To study their structure well, it is necessary to make sagittal sections. In a welldirected section (pl. XXVI, fig. 45), the tentaclar nerve can be seen, intercalated between the muscles and the connective tissue. As I have said above, it should be considered a ganglion. Indeed, it is covered on its external border with epithelial-ganglionic cells with an external nucleus and a fine cellular filament crossing the entire thickness of the nerve layer. This nerve gives off numerous fibrillary branches with some intercalated nerve cells that go to end at the periphery of the tentacle. The sensive cup is formed by a projecting epithelium. At the top is a small invagination with cells a little more delicate than the others. In sections parallel to the surface of the tentacle the cupules can be cut tangentially: we see in the center a cavity of invagination, then a ring formed by invaginated epithelium surrouonded by another ring formed by the projecting epithelium.

The nerve branches end at the base of the cupule in the epithelial clles. The living sensory cupules are very interesting to observe with a microscope. Increasing the number of preprations results in having tentacles approximately in profile. The invagination is evident. A group of very long and very active cilia is found at the base and brings in water. 
In addition to these special endings, there are also many ordinary tactile endings. The branches, a little smaller than the preceding, go toward the ectoderm and disappear into the epithelial cells without any appreciable differentiation (reported by Hamann (1883).

The sensitive cupules are found probably in all species of the genus Synapta. At least those of our coast and the Philippines (Semper) have them. Semper has also described them with long cilia in Anapta gracilis. Semon reported them in Chiridota venusta Semon (164). I cite this species only for reference because generally Chiridota lacks them.

The cupules were discovered by de Quatrefages (1842) in Snapta inharens. He took them for small suction cups, followed in that by J. Müller (1852) and Bauer and Semper (1868) who called them Saugnäpfchen. Hamann (1883) recognized their true nature and named them Siinnesknospen. He saw the nerve branche that goes there but the epithelial invagination completely escaped him. He attributed with reserve an olfactory function to them.

Semon (1887) was concerned only with their physiology. He made it the site of smell and taste, based on various observations. When crystals of chloral hydrate are placed near the tentacles, they retract immediately. From this he concluded the organs respond to odors.

Physiology. - I completely agree with the opinion of Hamann and Semon. These cupules have evidently a special sensitivity, very probably olfactory that functions to sense either a change in the constitution of the environment or the presence of noxious substances. The stimuli they experience, thanks to the ciliary current, are transmitted to the tentacle nerve, gangliated as is known and a reflex contraction occurs if appropriate. When the stimuli are sufficiently strong to be transmitted to the center, the animal react in some manner, either by fleeing, or secreting mucus, etc.

Holothuroids. - The tentacles of aspidochirotes and dendrochirotes, which appear so similar to those of Synapta, do not have special endings. The nerves end simply in the epithelium, very thin in Cucumaria, very thick on the internal border of tentacles of Holothuria impatiens. No functions of special sensitivity has been attributed to them. In the tube feet, the ganglionic nerve located in the connective tissue layer is mixed at its end with the epitheoial cell of the sucker (Jourdan, Hamann, Semon) and ends in a intraepithelial plexus that is very difficult to see.

CRINOIDS. - The tentacles have several irregular rows of very projecting papillae described in Antedon (W. Thomson), Pentacrinius (Joh. Müller), Bathycrinus (H. Carpenter), etc. Numerous successful studies have been done on these papillae, but it it especially Perrier and Jickeli who have established their structure. I do not add to their description, confirmed recently by Hamann.

The papillae, greatly expanded at their base that merges with the tentacular epithelium, looks like ribbed silk and ends in a small trilobed head on which are three very delicate straight cilia, discovered by Perrier. The basal epithelial cells (Jickeli), between which are nerve fibrils, are exended by very narrow filaments (producing the ribbed appearance) that end at the trilobed head and probably to the silk. Finally, a shiny fiber is found at the center. Its existence is well proven (Perrier, Jickeli). The fiber is often full of nuclei. It appears to be a muscle that retracts the papillae and that is lost at the base in the midst of the longitudinal fibers of the tentacle.

The flagellum described by Jickeli on the head of a papilla has not been seen by anyone else and its existence is considered as improbable. To this description, I shall add the following facts: When the papillae stained with safranin are examined with a microscope, the basal epithelial cells are very distinguishable. The large nucleus is strongly stained. The filaments they give off are more or less visible and are not seen at all in the central fiber. Nearly always in the grooved part that ends by the head, are found elongated corpuscles, very strongly stained by safranin. They at first could be taken for small nuclei but when a number of preparation have been examined, their 
variable form is so great that it is event they are not nuclei. Sometimes they have the appearance of small lentils placed on the side or of elongated spindles. Sometimes they extend into the basal cells where they are lost. Finally, their number is variable and they sometimes appear completely lacking. I do not know at all the significance of these strongly stained spindles. Certainly they have some importance because I have found them in tactile papillae of Pentacrinus and various ophiuroids.

The tactile function of the sensory papillae is evident. But it is not impossible that they are also have a role of olfaction.

OPHIUROIDS. - All the tube feet are innervaed in the same way. The radial band (or the oral ring) gives off a ganglionic nerve to the peripheral cells. This nerve goes to the tube foot and makes a semi-circle. It is much thicker than the nerve itself, equally rich in epithelial-nerve cells (pl. XXVI, fig. 36). As I have recognized in embryos of Amphiura squamata, all these parts are derived from ectoderm and primitively exterior. It is only by a secondary process that they are embedded in the tissue (compare figs. 27 and 36).

Very near the place where they nerve dilates to form the ring, leaves from the latter the properly so called tube foot nerve that is purely fibrilar. It is located in the connective tissue layer between the muscles and the epithelium and go to othe end of the amblacrum. There, it divides and its branches end at the external cells without having had any special differentiation.

There are only two exceptions: in Ophiothrix (O. fragilis, echinata, etc.), the entire tube foot is covered with small tactile cones, more or less projecting according to species (Apostolidès, Koehler, Cuénot, Hamann). In Ophiactis virens, as I have verified after Simroth, the tube foot ends in a rounded head and has a large number of projecting papillae on its cylindrical part. At the base of these papillae are the nuclei of the epithelial cells that extend by fine filaments to the end of the papilla, exactly as in Antedon. These filaments even cross the cuticle. I have not seen cilia on them (figure in Hamann, 71). In preparations stained with safranin are a large number of papillae with fusiform corpuscles, stained strongly in red and variable in form. They are located between the celluar filaments and are completely similar to those we have reported at the same location in Antedon rosacea (methyl green gives the same results, a little less marked however).

The nerve branches divide in a way to give a small branch to each papilla. Hamann has given good figures of them, perhaps a little schematic (71, taf. XV, fig. 3 and 4). Simroth gives a figure of the entire tentacle of Ophiactis virens (169, taf. 34, fig. 38). It is interesting to note that the tentacles of young individuals of Ophiothrix are absolutely identifical to those of Ophiactis virens.

Nothing is known about the physiology of the tentacles. If their tactile functions are easy to verify, it is not the same for odor and taste. The buccal tube feet, especially the internal ones (first buccal tube feet) are, in general, very different from the others. The epithelium is thicker. Perhaps they also have a physiological differentiation, olfactory for example. Indeed, Preyer has concluded from his experiments that the olfactory organs are locaed near the mouth.

It is proven that ophiuroids, like asteroids, perceive odors perfectly and use this sense to search for prey. Fishermen ofen find ophiuroids and Luidia in their nets devoring their bait (Roscoff).In aquaria, it is easy to see ophiuroids (Ophioderma) go in a straight line to a morsel of crab or fish that has just been put there as Preyer has observed (p. 224; 150, t. 7). The organs of olfaction can only be the tentacles and more specially those in the neighborhood of the mouth.

ECHINOIDS. - I confirm in large part the nice research in urchins of Hamann (69). In the three groups of regulars, clypeasteroids, spatangoids, the tube foot nerve from the radial band is ganglionic as usual (pl. XXVII, fig. 38). It crroses the test accompanied by the nerve that will murge with the peripheral plexus (Hamann has not seen the distinction of these two branches. 
Prouho has recognized them I Dorocidaris). At contact with the tube foot (proximal side in relation to the median line of the radius), it enters the epithelial layer and then goes to the free end. A little before reaching the terminal disk, it swells obviously and forms a ring around the tube foot. It is this ring that gives off radial fibrils going in the epithelium of the sucker. I refer to the excellent figure of Hamann (69, taf. 14, fig. 5). For the ordinary locmotory tube foot, I believe the arrangement is the same. I have not found in Strongylocentrotus lividus the complicated paths figured by Hamann. I have seen only a terminal ring from which a plexus innervates the sucker. The modified tube feet that are not lomotory (peristomial tentacles of spatangoids, respiratory tube feet of the petals of spatangoids and clypeasteroids. The sensory tube feet of Echinocyamus and Echinodoiscus biforids, etc.) have either warning sensory mamelons (petal tube feet) or sensory endings with tactile bristles (spatangoids), etc. The arrangements of the terminal nervous system will be considered better in the section on polymorphism of the tube feet.

Do tube feet, in addition to their roles in locotion and respiration, have spcial sensory functions? This is without doubt. They are first of all of great importance from the tactile point of view, especially those of the aoral surface of clypeasteroids, spatangoids and a large number of regulars. When an urchin is very quiet, even immobile, all the tube feet will extend and seem thus to explore the surroundings. At the least touch, they are retracted, the adjacent spines begin to move and are bent towards them to protect them. Tube feet and spines soon take their normal position when the cause of disturbance disappears.

The ten buccal tentacles of regulars and clypesteroids that have a different make up than the ordinarly tube feet and are richly innervated have been considered by Noll (135) as being perhaps taste or olfaction organs. In the absence of definitive experiments, I can only report this very reasonable opinion. The terminal disk of the buccal tube feet is covered with a thick epithelium that is lacking in the locomotory tube feet. They have no adhesive faculty. Without prejudging their functions, it is probable they also have an important tactile role and that they can inform the animal on the form and nature of the bottom.

In various clypeasteroids (Echinocyamus pusillus, Echinodiscus biforis) I have recognized small tube feet (pl. XXVIII, fig. 55) ending in a richly innervated epithelial mamelon close to the test. These tube feet that can serve no function in respiration or locomoition, are evidently organs of special sensibility. We have, so to say, no information on the physiological role (from a sensory point of view) of the diverse varieties of tube feet. There are numerous experiments to make that, I do not doubt, will give much of the expected results.

ASTEROIDS. - The epithelial covering of the tube feet is, as is known, continuous with the radial band (pl. XXV, fig. 21). In addition, there is a thick longitudinal layer of epithelial nervous fibrils on the entire height of the tube foot and its periphery (Ludwig, Hamann, Cuénot) without any ganglionic differentiation being noticed. A little before the sucker, this layer swells and forms a ring of circular fibrils as in urchins. From this ring radiates a larger number of fibrils placed between the epithelial cells of the sucker. The nerve layer is thicker on the sucker than on the body of the tube foot as can be expected because of the great sensitivity of this part.

Hamann described a large quantity of sensory cells (Sinneszellen) in the sucker and tube foot. I have previously given the reasons that make me doubt their existence in this cell type. In very good dissections (tentacles at the arm tip), I have always seen cellular filaments cross the nerve layer to attach to the connective tissue wall without have any continuity with the nerve fibrils.

The last tube feet pairs are completely different: these very long and slender appendges, lacking suckers, continually explore the surroundings like the tentacles of Helix. The nerve layer there is 
very thick from the base up to the end (see 28, pl. 3, fig. 21). These tube feet are also extremely delicate tactile organs.

Olfactory function of the tube feet. - It is known that the asteroids are very endowed from the olfactory point of view. They recognize at some distance the presence of dead prey, crabs or fish, and move in a straight line to them as Romanes and Ewart (155) showed. But there is no agreement on the localization of the olfactory function. The different tube feet do not have special sensory differentiation. According to Romanes (158) the sense of smell would be widespread over the entire rays, especially on the oral surface. In fact, asteroids whose arms have been cut and the rays thus shortened continue to pursue their prey. Preyer (150) also indicates the olfactory sense is diffuse. Prouho (152), who does not seem to have been aware of the previous studies, to the contrary localized it to the end of the arms, especially in the tactile tube feet without suckers. When the ends of the rays are cut off, the asteroid no longer seems to sense the prey placed nearby.

These experiments, done on well acclimated animals, are much more demonstrative than those of Romnes and Preyer.

\section{VISUAL ORGANS}

Ocular organs exist with an extreme degree of reduction in asteroids. At the base of the terminal tentacle is a small patch brightly colored red. This ocular patch is formed by the aggregation of a large quantity of small, conical hollow cavities covered wih a pigmented epithelium related to a thick layer of nerve fibers. The cuticle of the radial nerve goes down into each ocular pit. For the histological details and figures, I refer to the work of Hamann (68) and myself (28). There is no conformation that can be related to a refractory apparatus. The small "crystalline cones" of Lange are nothing other than the cuticular plates of pigmented cells. Finally the ocular pits are hollow (Lange, Hamann, Cuénot) and their cavity does not contain a lens, amorphous or not, as indicated by Hæckel (1860), Mettenheimer, Jourdain (1865), Hoffmann, Teuscher and more recently Carl Vogt and Yung. The small stiff cilium described by Carl Vogt and Yung on each pigmented cell must be an artifact because neither Hamann nor I have found it. The ocular patches of asteroids very vaguely inform these animals on the presence or absence of light. According to Romanes and Ewart (155) and Preyer (150), asteroids from which these visual organs are removed no longer move as usual toward lighted area of their aquarium.

Although well coordinated experiments have not been done on this subject, it is known that echinoderms sense light by the entire surface of their body (photodermal vision) and expecially by the points that are richest in nerve tissue (terminal tentacles of urchins?). According to Romanes and Ewart and Preyer, ophiuroids would be indifferent to light rays. Except for asteroids, there are no differentiated visual organs. It has been demonstrated that the diverse colored patches described under this name (terminal pores or oculars of urchins, intertentacular patches of synaptids) are only pigmented masses without any sensory importance ${ }^{25}$

The Sarasins (157) have considered the patches of sapphire blue that occur in great quantity on the integument of various Astropyga and Diadema visual organs or at least as points of greater sensitivity to light. As I have not examined the types involved, I cannot give a positive criticism. But after examining the text and figures of the Sarasins, it seems to me unlikely that the blue

\footnotetext{
${ }^{25}$ According to Ludwig and Bartels (Zool. Anz. 1891) the paired pigmented patches found at the base of the
} tentacles of Synapta vittata, Orsinii, lappa and vivipara receive small nerves and are certainly sensory organs. 
patches would be visual organs. They are first in considerable number (see the figures of the Sarasins) in the interradial zones, the periproct, etc., which does not make them very exceptional. The histological details are scarcely satisfactory and several figures seem to be more related to large mucous cells than of sensory conformation. I believe the conclusions of the Sarasins should not be accepted without reservation and that confirmation of their views would be far from useless.

\section{WATER VASCULAR SYSTEM}

The water vascular system is absolutely characteristic of echinoderms. Nothing is found in any other group that can be compared to it. The pseudo-vascular system of sipunculids has only a very superficial resemblance to the water vascular system of synaptids. We have shown (32) that this was mostly a glandular lymph gland. The dorsal pore of Balanoglossus, recalling in the first stages the water pore of echinoderms, opens in the adult state in one of the divisions of the enterocoel, and nothing else recalls the water vascular system. Finally, the homology that Hartog tried to establish with a left nephridum appears to me lacking in any foundation (see my note in response to Hartog, 30).

General development. - The water vascular system appears as a diverticulum of the left enterocoelic vesicle. The diverticulum or hydrocoel forms the oral ring, the five radial canals and the water canal that opens freely into the anterior enterocoel. This, in turn, opens to the exterior by a ciliated pore. Later, in the progress of development, the water canal approaches the external pore becomes continuous with it. The anterior enterocoel, interposed between the pore and the canal, persists in the adult, taking a great development (asteroids, ophiuroids and urchins) or nearly completely atrophies (holothuroids and crinoids). What is important to remember, as the good work of Ludwig and Bury has shown, is that the hydrocoel never opens directly to the exterior, and that it is only later that the water canal seems continuous with the external pore.

\section{SYNAPTIDS}

It is in the synaptids that the water vascular system has the greatest simplicity. Théel thins that this is consequently a regression. This is not our opinion. For us, the water vacular system of synaptids represents, or nearly, the form under which it appeared for the first time in echinoderms. We will first study its anatomy in the adult Synapta inhoerens (pl. XXVIII, fig. 52). It consists of a very large periesophgeal ring that gives off two diverticular that project to the exterior and constitute the buccal tentacles. Towards the interradius C D, the ring receives the water canal that opens freely into the coelom by a madreporite with few pores. Nearly opposite in radius A, it has a Polian vesicle with a long pedicel.

There is no trace of radial canals. I have made very close sections that have shown with perfect evidence that the oral ring does not give off any branches other than the tentacles. This is not the generally accepted opinion. Metschnikoff and Semon accepted their existence in the larva. 
Hamann has represented them in the adult, but the latter author was misled by the radial sinus (schizocoedl) that we will desribe in another section ${ }^{26}$.

\section{HOLOTHUROIDS}

I set aside the molpadids for which we unfortunately have no precise information. It appears (Sember, Sluiter, Teuscher, Danielssen and Koren) that the radial canals exist in these types (Haplodactyla, Caudina and Trochostoma, etc.) and that there are even lateral diverticula that stop at the edge of the skin instead of opening outside to form tube feet. Is will be completely indispensable to study molpadids again in order to know if the suppression of these appendages is really due to a regression, as Théel thought, or if it is, to the contrary, an intermediary state between synapids and holothuroids.

In the simplest holothuroid (Cucumaria), the oral water ring is very volulminous and has a Polian vesicle and a stonecanal that opens into the coelom by a more or less complicated madreporite. It gives off the five radial canals. It has been perfectly demonstrated (Hérouard) that the oral ring does not have tentacles, to the contrary of the synaptids. The Polian vesicles and the stone canals can be multiple but these are secondary. There are notably many water canals in Cucumaria maculate (Semper, taf. 14, fig. 5) and Holothuria chilensis (60-80 tubes).

In Cucumaria, Thyone, etc., the first pair of appendages of the radial canals are the ten peribuccal tentacles. These tentacles have a more or less ramified external portion and an internal portion or vesicle (tentacular cul-de-sac). I can confirm completely the excellent descriptions of Hérouard (73). In several aberrant dendrochirotes, the number of tentacles is greater and often not in multiples of five.

In some Holothuria, there are twenty buccal tentacles instead of ten, i.e. that these are two first pairs of tube feet that are transformed into tentacles. The separation of the two pairs is often visible because of their difference in size (Thyonidium, Pseudocucumis).

There are fifteen buccal tentacles in Haplodactyla molpadionides (Semper), twelve in Caudina Stimps.

In elasipods, the number of buccal tentacles varies according to species. It varies between ten and twenty. As in the preceding groups, these tentacles are clearly detached from the radial canals. (For greater detail on this subject, see the list of Ludwig in 114, page 93.

Along their entire length, the radial canals have numerous locomotory and tactile tube feet with an internal vesicle. The tube feet adjacent to the cloaca are only tactile. Finally, the radial canals around the anus pierce the integument and end in contact with the ectoederm and form the terminal tentacles, vestiges of the ancestral formation, and are little developed in adult holothuroids.

This is the normal type. In secondary adaptations, there are numerous modifications. The tube feet of the trivium take a great development because of their locomotory role. Those of the bivium become rudimentary (Colochirus, Holothuria, Stichopus, etc.). In elasipods, the differentiation goes further. Often the tube feet of the bivium and those of radius A have completely disappeared (Elpidia glacialis), while those of radii B and E have taken a more abnormal form (for details, I refer to special memoirs, Semper, Théel, etc.).

\footnotetext{
${ }^{26}$ Ludwig and Barthels (Zool. Anz., 1891), at nearly the same time as I, recognized the absence of radial canals in the synaptids they studied.
} 
Development (synaptids, holothuroids). - Study of development is indispensable to understand the water vascular system of synaptids and holothuroids and especially to see what remains to be studied. Imagine the already formed oral ring from the enterocoelic diverticulum, as is known, communicates with the exterior by a water canal with a tall ciliated epithelium. On the wall of this canal is a package of cells, described by Metschnikoff, and that, according to Bury, are the last remains of the enterocoel primitively interposed between the water canal and the external pore. As is known since the nice research of Theel, this stage of the water canal is fixed in various elasipods (see 180, page 137), by which the water canal opens to the exterior by several pores. It is probable that making sections in these speies, the rest of the enterocoel interposed on the canal wall will be found. For me part, I have not been successful in Elpidia glacialis that lends itself very poorly to this study.

The water canal opens to the exterior by a single pore and has on the sides the rest of the entercoel, evidently the ancestral form that existed in the ancestral holothuroids and synaptids and that we find identical in the other groups of echinoderms. But in the extant species of synaptids and holothuroids, evolution continues. The external pore is closed. The water canal, still engaged in the skin, ends in a coecum. This stage that Ludwig recognized in a young Chiridota rotiferaa Pourtalès $1 \mathrm{~mm}$ in length, is fixed in adults of various elasipods Oneirophanta mutabilis, Orphnurgus asper, Irpa abyssicola, Benthodytes papillifera, Elpidia glacialis), as can be seen by the studies of Théel and confirmed for Elpidia by Danielssen and Koren.

Finally, a more or less complicated madreporite is formed on the path of the canal (Semon in synaptids). The distal portion engaged in the skin, is resorbed and disappears producing thus the state in extant synaptids and holothuroids in which the stone canal opens freely into the coelom.

We pass now to the development of the tube feet. In synaptids, the oral ring produces five diverticula that are interradial because they are placed between the five radial nerve cords. The figures of Metchnikoff (126), Ludwig (108), Semper (165) show very clearly this relation and I do not understand why Semon wants to consider them radial. These five diverciular constitute the five primary tentacles that exist in all young synaptids (they are shown in the figures of Metschnikoff and Semon for Synapta and of Ludwig for Chiridota rotifer, etc.). Later, their number increases in a variable manner. There are twelve tentacles coming from the ring in the Synapta of our coasts, from ten to twenty in various synaptids (see list of Ludwig, 114, page 93).

According to Metschnikoff and Semon, the oral ring then produces five longitudinal canals that constitute the five radial water canals. (Bury also accepts these results). But these canals, as I said previously, certainly do not exist in the adult. This makes me believe that embryologists (which moreover are not based on sections) have been led to error by some other radial organ, muscle or nerve. Yet their figures are so clear that this is a question that it is indispensable to study again.

In holothuroids, there are also five primary tentacles coming directly from the oral ring. They are shown in the figures of Krohn, Joh. Müller (128), Danielssen and Koren (35) Selenka (162). Then are formed five longitudinal canals that constitute the radial water canals. The first formed bifurcate and forms two projecting tentacles with a sucker (Danielssen and Koren, Selenka). There still remains some obscurity on the importance of these different parts. The five primary tentacles appear to correspond well to those of synaptids, but I do not know if they are interradial. The figures of Selelnka are not very clear in this regard. As for the transformations that lead to the adult state, they have been followed only in Holothuria tremula Gunn. (by Daneilssen and Koren). The primordial tentacles appear to persist and new tentacles formed between them will constitute the 
first of the buccal tentacles. In adults, these always seem to be modified tube feet coming from the radial water canals and do not come from the water ring ${ }^{27}$.

In spite of the obscure points of development, it can be concluded that the holothuroids ontogenetically pass through a form analogous to synaptids, whose water vascular system is consequently a lower phyologenetic stage.

These five primary tentacles, persisting in synaptids, non-homologous to those of holothuroids, will no longer appear in other echinoderms. The first diverticula of the ring will form the five radial canals and nothing else. This is what led Semon to formulate (165) a theory that I hold unacceptable. For him, the five primary tentacles will correspond to the five radial vessels of other echinoderms. In addition to the impossibilities that are against the theory in holothuroids, where the two parts exist concurrently, it is very evident in synaptids, as Bury (17) pointed out that the five primary tentacles are interradial in relation to the nerves and muscles whose position determines the radius in all echinoderms. Semon also relies on the fact that the stone canal is placed between two primary tentacles. Because the first is interradial, he concludes that the second ones are radial. Bury has correctly opposed this way of thinking. In the embryo, the water canal is not intercalated between two tentacles, but is placed between one tentacle and the radius, i.e., "adradial." Likewise in the adult, the interradius of the stone canal passes exactly by a primary tentacle (pl. XXVIII, fig. 52).

\section{CRINOIDS}

Although I have nothing new to report, I will summarize the recent work of Bury (16) to show that crinoids at the beginning of development have a typical water vascular system. The hydrocoel forms a ring surrounding the esophagus. It gives off a water tube that opens into the anterior entercoel. This, in turn, opens to the exterior by a water pore. As in holothuroids, the interocoel is interposed between the tube and the pore and is not greatly developed. It remains in the body wall and soon its epithelium cannot be distinguished from the surrounding mesoderm (parietal canal of Perrier and Bury). At this moment, the arrangement is identical to that which is fixed in many adult echinoderms. The oral ring leaves the stone canal (columnar epithelium), which continues by a dilated portion with a flat epithelium, representing the enterocoel. A short canal with columnar epithelium leaves this and opens to the outside by a pore (16, p. 283).

The oral ring has five radial groups of tentacles, each with three tentacles. The median of each triade, larger than the others, will be the radial tube foot that bifurcates later into the arms, etc. The lateral tentacles remain on the disk.

At this moment, Antedon, except for the number of tube feet, is comparable with any echinoderm. But this stage, which is probably fixed in cystids and blastoids, is not found in any present species. It then forms a stone canal in each interradius similar to the first, which makes five in all (fixed stage in Rhizocrinus lofotensis, according to Ludwig and probably also in Actinocrinus verneuilranus ${ }^{28}$ ccording to Wachsmuth and Carpenter. Then the number of stone canals and pores multiply again and again, but there is not a great rigorous correspondence between them.

\footnotetext{
${ }^{27}$ According to recent studies by Ludwig (Sitzungsber. Akad. Wiss. Berlin, 1891), the first five tentacles of holothuroids coming from the radial canals are not at all comparable to the primary tentacles of synaptids. ${ }^{28}$ Fossil of the Upper Silurien with calcium carbonate.
} 
An important remark: the ciliated pores of crinoids does not represent the pores of a madreporite as is sometimes said, because each pore corresponds, at least at the beginning, to a stone canal.

\section{ECHINOIDS}

The general characateristics of the water vascular system of urchins is well known. Therefore I shall discuss only some specific points. I will begin with a summary of development.

Development. - When the urchin is still in the pluteus form, the oral ring or hydrocoel gives off a water canal that opens into the anterior entercoel. Little by little, this tube approaches the external pore of the enterocoel until it becomes nearly continuous with it. At this moment, it has a lateral orifice by which it opens into the rest of the enterocoel. These important relations have been figured well by Bury (197, pl. 38, fig. 7).

The enterocoel, instead of becoming completely obliterated as in synaptids, holothuroids and crinoids, has a great development while keeping its relationship with the water canal. It extents parallel to it and at its interior develops a glandular organ, the axial gland that nearly obliterates it except at the lower part. In Echinocyamus pusillus, the only clypeasteroid of our coasts, the stone canal completely keeps the ancestral physiognomy. But in the other urchins, the terminal portion of the tube is complicated. Instead of a single pore, it opens to the exterior by a more or less complicated network of canals and holes that constitutes the madreporite. The rest of the stone canal does not change and always keeps its lateral communication with the enterocoel (cavity of the axial gland). In Spatangus purpureus only, as shown by Prouho (151), the stone canal, a little above the point where it communicates with the axial gland, is obliterated and disappears. It splits into two parts: a proximal part connected to the oral ring and ended in a cecum. The distal part communicates with the axial enterocoel and the exterior.

Development of the tube feet. - The oral ring first gives off five very prominent radial diverticula that are the locomotory organs of the young urchins. These five primordial tentacles (not to be confused with the five primary tentacles of synaptids and young holothuroids) later will be the terminal tentacles. Between them and the mouth appears a pair of tube feet in each radius (which, in echinids and clypeasteroids will become the buccal tube feet. Development then continues. New pairs of tube feet form in contact with the terminal tentacles that move little by little towards the apex to stop against the terminal plates (oculars of the adult).

In all young urchins, regular or irregular (Lovén, Agassiz, etc.), the water vascular system is constituted in the following way: in each radius is found a pair of identical tube feet, communicating with their internal vesicle by a single pore. This ancestral form is fixed nearly intact in the genera Neolampas, Palaotropus and the family of Pourtalesia (Pourtalesia, Spatagocystis, Echinocrepis), Urechinus, Cysterchinus, Calymne. It is only later differentiated into petaloid and nonpetaloid zones, etc. It is thus secondarily that the tube foot communicates with its ampulla by two pores.

Anatomy. - The oral ring, where it gives off the stone canal and the five radial canals, has the simplest relation in the spatangoids where it is located at the edge of the periesophageal cavity. In gnathostome urchins, as a result of development of the jaws, it is far from the mouth, at the base of the matisticatory apparatus. In nearly all these latter, it enters into connection with the glandular 
system associated with the oral lacunar ring (Polian vesicles, glandular ring of authors) whose constitution and physiology we shall examine is a subsequent section.

In regulars and clypeasteroids, the five radial canals extend the length of the jaws (pl. XXVIII, fig. 53), passing under the auricles and down towards the apical pole where they end in the five ocular plaes that surround the periproct by one or two (arbcioids) rudimentary terminal tentacles. Where they pass under the auricles, the give off a recurrent branch (Perrier, Koehler, Prouho) that leads to the tube feet of the peristomial membrane.

The stone canal, bordered as is known by a tall ciliated epithelium, opens by a wide canal into the oral ring and descends towards the apical pole to end at the madreporite. It is necessary to study with care the relations it has with the enterocoel. As we have already said, the ancestral condition is best kept in Echinocyamus pusillus. It is thus we will begin with it (pl. XXX, fig. 71). A single pore is found towards the center of the aboral surface, reported in 1874 by Lovén. It is covered with a tall ciliated epithelium. After crossing the calcareous wall it opens into a very large flattened ampoule with a squamous epithelium. This ampoule is the remains of the original enterocoel interposed between the stone canal and the pore ${ }^{29}$. It communicates broadly with the cavity of the very reduced axial gland and the aboral sinus (going to the gonads). At the upper end of ampoule ends the sgone canal that crosses the entire coelom to end at the oral ring. We see thus that an injection made by the external pore would pass on one hand into the ampoule and its dependencies and on the other into the stone canal.

In regular urchins (young Echinus acutus, Strongylocentrotus lividus, etc.) the arrangement is a little more complex (pl. XXX, fig. 72). The numerous madroporite pores all end in a very vast cavity, a kind of bulb (not to be confused with the ampoule described before in Echinocyamus. The stone canal, covered with the characteristic epithelium, where it is continuous with the ampoule, has a very large opening on the side by which it communicates by a canal with the cavity of the aboral sinus ring that is also a dependency of the cavity of the axial gland. The columnar epithelium is interrupted abruptly at the opening to be replaced by the flat epithelium of the enterocoel. An injection into the cavity of the axial gland will thus pass one on hand into the stone canal and on the other hand to the exterior by the madreporite pores (Perrier, Koehler, Prouho, etc.). In Dorocidaris papillata, Prouho (151) has clearly recognized these facts. The work of Bury and the examination of Echinocyanus makes it possible to give a more exact interpretation. The stone canal annex of Prouho does not have an autonomous existence: it corresponds to the lateral opening of the stone canal, connecting the axial enterocoel with the stone canal and thus with the exterior. The Sarasins (159) have also recognized in Asthenosoma urens the connection of the ampoule on one side of the stone canal (Stammelblase) with the axial gland (that they interpret as a ureter). Into the "Sammelblase" opens from the other side the madreporite canals. From this interpretation, the facts are identical to those that we just described.

In Echinodiscus biforis (clypeasteroid), the sections show perfectly clearly (pl. XXX, fig. 69) that the stone canal opens into the axial enterocoel (cavity of the axial gland). It reforms a little lower to receive the numerous madreporite canals that cover nearly all the apex.

Finally, in spatangoids, the figures of Hamann (69) and Prouho (151) show that the stone canal, after having received the madreporite canals, both connect with the cavity of the axial gland. In Spatangus purpureus, as shown by Prouho, the stone canal disappears some millimeters above.

\footnotetext{
${ }^{29}$ In a figure of the urchin embryo, Bury shows the stone canal that communicates laterally with an "ampula" a diverticulum of the axial enterocoel. This transitory arrangement is absolutely fixed in Echinocyamus (see 17, pl. 38, fig. 9).
} 
Polymorphism of the tube feet. - In young urchins, as in all other echinoderms, the tube feet are all similar, elongated and ending in a kind of a more or less flat cone. But as the animal ages, there is a functional differentiation that results in some groups in a more remarkable polymorphism.

In regular urchins, the tube feet connect with the ampullae by a pair of pores and nearly always have a sucker. However, in diadematids and abacids, the tube feet of the aboral surface, that cannot function in locomotion, end in a point and lack all calcareous structure. Hamann has studied them well in Centrostephanus (69). There is little to note that the buccal tube feet (lacking in cidaroids and echinothuroids) end in a bilobed, non-adhesive swelling that is probably sensory.

In clypeasteroids, the polymorphism is very exaggerated. However, the tube feet (except those of the petaloid zones), keep the embryonic condition and connect with their ampulla only by a single pore. The tube feet that are near the mouth are larger than the others. The ordinary tube feet, distributed on all the test of the animal, are very long, covered with a thick epithelium and end in a round button (pl. XXVIII, fig. 55). With these are found partaicularly on the oral suface (Echinocyamus pusillus, Echionodiscus biforis) short and massive tube feet that end in a flat extremity in which the connective fibrils are mixed with the epitheial cells as in the ordinary sucker. These tube feet are very probably locomotory. Finally, in these two species, there is on the two surfaces a third type of tube foot, probably with special sensitivity. They are a round button located near the edge of the test, formed of tall, richly innervated epithelial cells. These small tube feet have an ampulla as usual. They are relatively more projecting in Echinodiscus than in Echinocyamus.

The tube feet of the petals, few in Echinocyamus (five to six pairs per radius), in very large number in other clypeastroids, are adapted for respiration. Their amapulla (pl. XXVIII, fig. 56) is very large and evidently involved in the production of a circulating current, as has been shown in the tube feet of regulars. In Echinodiscus biforis, the external portion has the form of a vesicle with a thin wall, crossed by tracts arranged radially in a fashion to force the liquid to circulate all around the wall. There are identical tracts in the ampulla. In Echinocyamus pusillus, these tracts are only in the external part. Moreover, the two canals that cross the test are covered with a dense epithelium, probably ciliated, that should produce the currents necessary for respiration. Finally, in these two species, the very thin epithelum that covers the external vesicle has in places projecting nipples, richly provided with nerve fibers that are evidently tactile warning organs ( $\mathrm{pl}$. XXVIII, fig. 56). The liquid that circulates in these respiratory tube feet is not renewed. It is saturated with oxyen in the external part, passes by one of the pores to go into the amulla where it gives its oxygen to the perivisceral fluid, then repeats the same path.

A. Agassiz has described macroscopically in several clypeasteroids the varities that we have just enumerated, except the rudimentary tube feet reduced to a small button that does not appear to have been observed by any author. We do not know for sure if they are truely locomotoy tube feet.

In spatangoids that are little differentiated (Echinoneus), the polymorphis of the tube feet is not great but it reaches a great degree in Spatangus, Echinocaridium, etc. Around the mouth are buccal tube feet, short and massive, ending in a bunch of small swollen branches, each with a calcareous skeleton. For their histological study, I refer to the figures of Hamann that I confirm in all regards (69). According to Robertson, Lovén, etc., these buccal tube feet search the sand and mud with their calcareous tufts to ingest large quantities into the digestive tubes. The tube feet of the four petals Oradii A, B, C, E), the only ones with two pores, are nearly the same as those of clypeasteroids (a little more ramified, however). The rest of the ambulacral zones have more or 
less long tube feet, ending in a conical non-adhesive part with the role of tactile organs. Those in the terminal part of radius D (median of the trivium) are often three large ones ending in a large disk (see the figure that Lovén has given of living Brissopsis lyrifera and those of Agassiz, Acdeste and Arope, 3, pl. 32 and 33.

Lovén (118) has studing in great detail the form and constitution of the tube feet of spatangoids. I can only refer to his beautiful figures.

\section{OPHIUROIDS}

The development of the water vascular system is slightly similar to that we just described for urchins. It is not much modified in the adult that keeps nearly entire the ancestral characters. We take as type a normal ophiuroid, Ophiothrix or Ophioglypha. We shall treat the water vascular system of Ophiactis virens in a special section.

The oral water ring has in four interradial Polian vesicles. In the fifth, it receives the stone canal whose path we shall describe later. The radial water canals have some pairs of tube feet lacking ampullae and that end in small terminal tube feet much more developed than in urchins. As especially the work of Simroth, Ludwig et al. has shown, there are twenty buccal tube feet located on the sides of the jaws that connect directly to the oral ring. From each side of the radial ring leaves a vessel that soon bifurcates to go into two superposed buccal tube feet.

The transverse canal that goes from the radial canal to the tube feet of the arms has a peculiarity whose importance escapes me. Sometimes it is truly transverse, i.e., it extends in a striaght line from the radial canal to the tube foot (Amphiura, Ophiothrix, Ophioglypha, Astrophyton), sometimes it forms a kind of $\mathrm{V}$ whose narrow angle is turned towards the aboral surface (Ophiocoma scolopendrina, Ophiactis, etc.). This V-shaped arrangement was reported by Teuscher in Ophiocoma crassispina and by Simroth in Ophiactis virens.

The stone canal is very interesting to examine, notably in Ophiothrix fragilis that has particularly clear arrangemetns (pl. XXIX, fig. 57). Its diameter is very small when it leaves the oral ring, but it bcomes a little more apparent when it enters into the sinus gland (that also encloses the axial gland. It is covered with the characteristic columnar epithelium. When it reaches the oral surface, it opens by a full canal into the sinus that surrounds it. Its epithelium is continuous with the flat epitelium of the enterocoelian sinus. The sinus continues, enters into the walls of the body and expands into a large flat ampulla covered with a cubic epithelium. A short ciliated canal leaves from this ampulla and opens to the exterior by a small pore placed at the edge of the bursal slit, completely at its end $\left({ }^{30}\right)$. This enterocoelic terminal ampulla is very complicated in form in Ophiactis virens, it is very reduced in Ophioglypha albida, but in every case that I have examined, the stone canal connects at its end with the enterolic sinus ni which it is enclosed. The exterior pore is asymmetric in ophiuroids being perforated at the edge of the bursa; slit. It is this that explains why it is impossible to see it from the exterior. Moreover, it is is extremely small.

According to J. Müller, Lyman, Lütken, and Le Conte, there are madreporites with more or less numerous pores in several species of the genera Amphiura, Ophiolepis, Ophioplocus, Ophionereis, and Ophiocnida. It is not the same in euryales. The pore on the madreporite (see the

\footnotetext{
${ }^{30}$ In my work of 1888 , I did not recognize this important relation, well recognized by Ludwig. I have shown the stone canal as opening a little before the bursa; slit. I have reviewed my preparation that probably belongs to a misformed specimen and that, in any case, remains completely isolated.
} 
figure I gave for Astrophyton clavatum, 29, pl. 5, fig. 1 and 2) is always found on the oral surface in the middle of the interradial zone. Finally, in Trichaster elegans (euryalid), according to Ludwig and Ophiactis virens, the stone canals become multiple (Trichaster has a stone canal in each interradius, reproducing in ophiuroids the situatin of Rhizocrinus in crinoids.

Development. - As shown by Bury, an intercoelic vesicle opens first at the exterior by a pore. The hydrocoel, formed later, opens in its turn into this enterocoel by a water canal. The external pore is first on the aboral surface (pl. XXV, fig 25) that recalls the fixed state in urchins and asteroids. But it fixed little by little toward the oral surface because of the migration of the oral plate that encloses it. Consequently I do not know the process by which it beomes lateral, instead of remaining in the sagittal plane. The enterocoeol, interposed between the stone canal and the external pore, forms the glandular sinus and the ampoule (at least in part). As we will see, it always remains in communication with a part of the stone canal and with the exterior. The adult ophiurod absolutely keeps the embryonic condidtion.

The five radial canals, ending in terminal tube feet, produce laterally first a pair of tube feet that open into the oral ring, then some others, intercalated between them and the terminal tube feet. The first pair, instead of following the movement and going into the arms, are the first pair of buccal tube feet in direct communication with the ring. The other buccal tube feet correspond to the second pair of tube feet of the arm. But I have not been able to see, in embryos of Amphiura, how the union of the two canals that originally opened into two superposed buccal tube feet occurs. Simroth figures (169, taf. 33, fig 27) in Ophiacatis virens, an interesting anomaly that shows a persistence of the embryonic state. In this specimen, the buccal tube feet of the first pair receive directly their canals from the oral ring. Those of the second from the radial canal as the other tube feet.

History. - I set aside the old authors to begin with the work of Simroth on Ophiacatis virens (1876), who one cannot admire too much the exactiness, who perfectly saw all that we shall describe (setting aside differences in interpretation). The communcation of the stone canal with the ampoule, and consequenty with the axial sinus (that Simroh called heart), did not escape him. But this indication was contradicted later by Ludwig, and since has not been seen. Ludwig has very well described the external pore and the path of the canal, but the connections of the ampoule has escaped him. He believed it was simply interposed bewtween the two parts of the stone canal and did not see that it connected with the axial sinus, of which it is only a dependency.

I pass in silence the fantastic work of Apostolidès (1882). Hamann (1889) has recently studied the question. He confirms the opinion of Ludwig regading the non-communication of the stone canal with the axial sinus, and describes again the ampoule in a very schmatic way. According to Hamann, the stone canal of Ophioglypha albida opens to the outside by two pores. For my part, I have seen only one, like Ludwig. Perhaps Hamann was mistaken because of an abnormal specimen. Finallly, the author describes likewise in Ophioglypha albida, an aboral pore (der Rükenporus) that connects directly the coelom with the exterior and that he compares to the ciliated pores of crinoids. I have carefully examined this extraordinary assertion with very close sections, both horizontal and vertical, and I must declare that I have not seen the least trace of a pore. Moreover, from the embryological point of view, as Semon has also remarked, the comparison of Hamann does not stand up because the stone canal has a perfectly distinct pore. Thus, in regards to the new affirmation of Hamann, I conclude there is little truth to the existence of a dorsal pore of ophiuroids. 


\section{ASTEROIDS}

The water vascular system of asteroids differs little from the ancestral form. The oral ring has some lymphatic glandular organs, Polian vesicles and Tiedemann's bodies (these latter are constant in the entire class, while the first is often missing). The five radial water canals, more or less moniliform, has a number of tube feet pairs, all with ampullae. The last pairs lack suckers and are transformed into tactile and sensory organs. The terminal tube feet are projecting and have at the base a bright red ocular cushion.

The tube feet, in young individuals, are always conical and lack suckers. They remain like this in adults of the genera Luidia, Astropecten, etc., and the ends of the arms in all general. However the tube feet of Luidia and Astropecten are adhesive, although very weakly. Most often, Luidia uses then for locomotion, like crutches. The ampulla is likewise simple or scarcely bilobed in all young individiuals. This is the condition in adult asterids, echinasterids, linckiads and Luidia. But in the other groups, and especially in those that we can call lower, they are divided into two very separated vesicles, both opening into a singe tube foot (asterinids, culcitids, astropectinids).

The stone canal has for the first time a singular complication. Its walls, until then membranous, are incrusted with calcaroues plates (from which the name sand canal has been given it) and moreover it is formed inside with more or less complicated calcareous folds that have the function of increasing the ciliated surface. This is at first a simple ridge of the internal wall (fixed phase in echinasterids, Asterias tenuispina). This ridge is birfucated at its ends and makes a kind of anchor (Asterina) whose points wrap around each other (Asterias glacials and rubens, Pentaceros, Gymnasterias). Sometimes the tube is divided into two by a septum with a fold on each surface in the form of an anchor (Astropecten platyacanthus, spinulosus, pentacanthus, young Astropecten aurantiacus). Finally, it can be crossed in all directions by irregular chambers in the form of a sponge (adult Astropecten aurantiacus and hystrix, Luidia, Culcita, Ophidiaster pyramidatus, etc.

The relations of the stone canal with the exterior and the enterocoel are the same in asteroids as in ithe other groups that we are going to study. The beautiful investigations of Ludwig on Asterina gibbosa (1882) aand Bury (1889) allow us to now understand well the known anatomical facts in adults. The stone canal is approached from the external pore, originally single, but always keeps its connection with the enterocoel (forming the axial sinus or glandular sinus that encloses the axial gland). Perrier has clearly recognized (114) in very young Asterias spirabilis, 8 to $20 \mathrm{~mm}$ in diameter, the hydrophore tube communicates "at the point where it is united with the end of the ciliated funnel, wiith the cavity that, I am sure of it, is certainly the same cavity of the sacciforme canal $^{31}$."

In adult asteroids, we have known for a long time (Greeff, Hoffmann, Teuscher, Romanes and Ewart, Perrier and Poirier) that an injection made by the madreporite penetrates both into the stone canal and into the glandular sinus. However, Sharpey, Tiedemann, L. Agassiz, Müller, Lludwig and Hamann have denied the fact. I have shown (1887) by sections, that in all the asteroids examined, there are madreporite pores that lead into the axial sinus and thus the latter and the stone canal are in communication with each other by the intermediary of the madreporite canals. Durham (1888) has shown, but as an anomaly, the same thing in Cribrella oculata. The fact is perfectly constant and it should be interpreted in the same way as in other echionderms, as being the vestige of the original communication of the stone canal with the enterocoel and the enterocoel with the interior. The difference that can be seen with urchins is more apparent than real. In urchins, the

\footnotetext{
${ }^{31}$ Synonymy of axial or glandular sinus.
} 
madreporite is formed by divertidula of the external pore so that, what ever the complexity, the stone canal always keeps its lateral connection with the enterocoel. In adult asteroids, to the contrary, the madreporite goes back a little higher, if I can express it thus, and encloses even the previously mentioned connection so that the stone canal seems to be perfectly continuous along its length and the axial sinus seems to open separately to the outside by special pores. The connection of the stone canal and the axial sinus occurs within the madreporite. Except for this secondary difference, one sees that the relations are identical to those in urchins and ophiuroids.

\section{TUBE FEET AND TENTACLES}

VALVE. - The diverticula of the water vascular system, tube feet or buccal tentacles have in all groups a special arrangement of valves that prevent the liquid contained in them from returning into the radial canals or the oral ring.

Ssynaptids. - Im Synapta, there are a dozen diverticula of the oral ring that go to a dozen exterior tube feet (pl. XXVIII, fig. 52). It is at the point where the internal portion meets the tube foot that the valve is found (pl. XXIX, fig. 62).

It was especially studied by Hamann (679) who only described it very incompletely (Senilunarklappe). In the middle of the very narrow passage that connects the tube foot and the internal reservoir, the connective tissue wall is reflected and forms a projecting button covered with an epithelium. On each side of the button is a supple, muscular membrane forming a kind of conical tube directed toward the exterior and to the interior which makes up the connective tissue ridge. When the tube foot is contracted, the liquid pulls down the two membranes on the median button and makes a hermetic seal. To the contrary, when the internal reservoir is contracted, the liquid opens the values of the flap and flows freely into the tube foot.

Holothuroids. - In holothuroids, the tube feet are an external part, projecting outside and an internal vesicle (tentacular cul-de-sac of Hérouard). The transverse canal from the radial canal opens where these two parts meet. This is where the valve is found, as Hérouard recognized in various dendrochirotes (Cucumaria) and myself in Holothuria impatiens. It consists, as Hérouard described very well (73, pl. 26, fig. 14; pl. 28, fig. 1, pl. 29, fig. 8), of two depressions surrounding the opening. When the tube foot or the vesicle contract, the liquid can pass freely from one into the other, but it cannot return to the transverse canal, the borders of the two depressions meeting and blocking the opening.

Crinoids. - In Antedon rosacea and Eschrichtii, Pentacrinus Wyville-Thomsoni, etc., there is no longer a free communication between the radial canal and the tentacles. In fact, these, at their greatest state of contraction, always remain full of liquid. The opening of communication is, iin fact, greatly narrowed and at this point is always found some muscular septa, analogous to those that separate the radial canals into chambers. These septa, when closed by tentacular liquid, probably form a valvular apparatus sufficient to close the opening.

Hamann said formerly that the valves do not exist in crinoids. However, several of his figures, like those of Ludwig and Perrier, show very clearly the valvular flanges we describe.

Echinoids. - The transverse canal coming from the radial canal opens directly into the ampulla (pl. XXVII, fig. 38). Its diameter is very small and the opening of communication itself strongly narrowed. In Dorocidaris papillata, a muscular circular membrane before the opening has borders attached to the walls and allow only a narrow opening. When the liquid of the tube foot tends to 
flow towards the transverse canal, the refolded membranes are applied onto the walls and stop all communication. I have found an analogous arrangement, although a little less evident in the buccal tube feet of Strongylocentrous lividus and Spatangus purpureus.

The valves of urchins were reported incidentally by Ludwig, after having described that of ophiuroids (107). He adds: "So will ich beilaüfig erwãhnen, dass ich eine ganz ãhnliche Vorrichtung auch bei Sphochinius granularis gefunden habe."

Ophiuroids. - The transverse canal is directly continuous with the tube foot. These is no, as one knows, ampulla. The valve (pl. XXVI, fig. 36) is found at the confluence of the canal and the tube foot. It has been very well described by Ludwig (107) and Koehler (88). Hamann exactly figures it (791, taf. XVI, fig. 9), but I do not see why, in his summary, he writes the following phrase (p. 365): "Den Ophiuren wie den Crinoiden fehlen die Klappen." Because of its small size, it is very difficult to recognize, but its existence in indisputable, both for the buccal tube feet and the radial tube feet (Ophiothrix, Opiocoma, Ophiactis, etc.). As in the holothuroids, the walls of the transverse canal are prolonged a little into the tube foot making a kind of truncate-conical tube. When the tube foot contracts, the walls of the tube are applied against each other in a way to close (very incompletely, as sections of the contracted tube feet show) the opening of communication.

Asteroids. - The valve, reported first by Jourdain (1866), then studied by Lange (1876), Ludwig, Hamann, Carl Vogt and Yung, is located in the transverse canal, not far for its opening with the radial canal. One can even recognize it by dissection in large species as Astropecten aurantiacus. The valve is a kind of membranous truncated cone attached by its base at the periphery of the canal and having at its truncated end, turned toward the tube foot, the opening that gives access to this latter. When the pressure increases in the tube feet or the ampulla, this membrane is folded and completely blocks the very small opening. One can, in fact, make an injection into the tube foot, even up to making it burst, without any passing into the radial canal. To the contrary, the injection passes easily into the entire system when it is injected by the radial canal. The valve has muscular walls, and perhaps adds its contraction to the pressure of the liquid.

The figures of Lange (95) and Hamann (68) are a little schematic. My sections have always shown more complicated images. As for Carl Vogt and Yung, they have been mistaken by poor preparation and probably have not seen the true valve.

Histological CONSTITUTION. - As histological investigations in the different groups have shown, the tube feet and buccal tentacles always have the same constitution: exteriorally, the more or less thick ectodermal epitheium ciliaited or not; a connective tissue layer often having an elastic differentiation and sometimes containing calcareous plates; a layer of longitudinal muscular fibers and finally the ciliated epithelium. These different layers are modified according to function. In the respiratory tube feet, they are reduced to their minimum thickness; the muscles, so thick in the powerful locomotory tube feet of asteroids and urchins, form a simple layer in ophiuroids, crinoids and holothuroids. The external epithelium is differentiated into organs of special sensitivity: cupules of synaptids, tactile cones of crinoids and various ophiuroids, etc. For the details, I can only refer to monographs of the different classes.

Suckers. - In three groups, the end of the tube foot is differentiated into a sucker, developed independently in most holothuroids, urchins and steroids. Numerous auothors have studied them: Jourdan, Semon and Hamann in the holothuroids; Hoffmann, Teuscher, Koehler, Niemiec, Hamann and Prouho in urchins; Greeff, Hoffmann, Teuscher, Joudan, Niemiec and Hamann in asteroids. It is essential to bring together these studies that complement each other. I shall add some new or poorly knowon details. 
Urchins. - I shall take most especially, as example, the locomotry tube feet of Strongylocentrotus lividus, but the description is probably appropriate for all urchins. The ectodermal epithelium, very clear in the column of the tube foot, encloses on one side the tube foot nerve whose fibrils run between the epithelial filaments. A little before reaching the sucker, the nerve is folded and forms a ring with circular fibers (Hamann), surrounding the tube foot. On all the cup of the disk, except in the very central depths, fibrous elements are intimately mixed with the epithelial cells so that it is impossible to trace the limits of the two parts (Niemiec, Hamann). The fibrils pass between the epithelial cells and go to insert onto the cuticle that is at this point a finely striated region formed of small brightly colored granules.There are two kinds of muscles: $1^{\circ}$ very short radiating fibers inserting on one hand the center of the sucker on a small connective tissue plate; $2^{\circ}$ the longitudnal muscles from the tube foot, inserting between the first, around the internal cavity so that with a superficial examination we could believe that they are only a continuation of the others.

The functioning of the sucker is easy to understand. They are applied closely onto a foreign body by its surface made rigid by the epithelium and fibrous tissue (without counting the calcareous pieces). The radiating muscles contract, pulling the center behind and producing thus adherence. By means of the longitudinal muscles, the urchin can "pull" on the suckers as on a solid mooring. To detach, the radiating muscles are relaxed and the sucker retakes its normal form because of its elasticity.

I shall not discuss the theory of Niemiec (134) who took fibrous bunds for muscles. The radiating muscles that alone makes it possible to understand the functioning of the suckers, have been reported until now only by Lovén in Toxopneustes (seen by transparency, 118) and Proho in Dorocidaris.

Asteroids. - The suckers of asteroids (Asterias, Echinaster, Pentaceros, Asterina, etc.) is identical to that of urchins, the same arrangement of epithelial tissues and fibers of the sucker; the same finely striated region under the cuticle; all the epithelium of the tube foot enclosing a thick nerve layer forming a thick ring below the sucker (Hamann, 68, taf. 2, fig. 14). There are radiating muscles to raise it, absolutely as in urchins, very distinct from the longitudinal muscles of the tube foot. Niemiec has seen fibrils mixed with epithelium of the sucker that seem to have escaped Hamann. But no author speaks of radiating muscles.

The conical suckers of Astropecten, whose adhesive power is very weak, are constructed completely differently (see the excellent figure of Hamann, 68, taf. 2, fig. 9). The fibrous layer, much thicker than in the column, is no longe mixed with the epithelium. There are no longer separated radiating muscles.

$\delta$. The functioning of the sucker is identical in asteroids and urchins. I thus shall not return to it. Given the independent existence of the longitudinal and radiating muscles, it is easy to understand the following observations: One can strongly grasp a tube foot and even cut it without the sucker detaching. But if one touches the periphery of the sucker, it detaches immediately (because of the relaxation of the radiating muscles); the fluid in the tube foot functions to extend the tube foot and expanding the disk; the tube feet whose amulla is broken can remain fixed and detach at will, but once detached, they cannot attach again. This proves clearly that the ampulla is only involved in the extension of the tube. This is what one finds well developed in the tactile and respiratory tube feet of asteroids and some urchins, the lateral feet of elasipods, the feet of the bivium of aspidochirotes, Colochirus, etc.

Holothuroids. - The sucker of holothuroids is very complicated and it is necessary to state that one does not understand its functioning very well. I have studied it in Cucumaria cucumis and 
Lacazii and in Holothuria impatiens and Sanctorii. The ectodermal epithelium, thin and poorly defined on the column, thickens considerably on the disk as all authors have reported. It rests on a layer of calcareous pieces. On the entire surface of the disk, it is mixed with packets of vertical fibrils (Jourdan) of fibrous nature that insert on the cuticle as in asteroids and urchins. The arrangement of these fibrils is very complicated and are not, in brief, of great interest.

The muscular fibers determine by the insertions into more or less deep cavities, rows around the central cavity. I have not seen separate radiating muscles.

Jourdan (86) has thoroughly studied the epithelium of the sucker. The descriptions of Hamann and Semon do not appear to me to be very exact. Hérouard is particularly concerned with the functions of the tube foot, but I do not accept without resrervation the interpretation that he has given to the process of adhesion.

\title{
GLANDULAR APPENDAGES OF THE WATER RING.
}

\author{
SYNAPTIDS AND HOLOTHUROIDS.
}

In nearly all echinoderms, the oral ring is in relation with lymmp glands that produce amoebocytes to the water vascular system. In synaptids and holothuroids (pl. XXVIII, fig 52), these glands are represented by the Polian vesicles. In the two groups, nearly in front of radius A., is appended to the oral ring a large hollow bladder that appears very early in development in the form of a sixth diverticula of the hydrocoel (the five others being the primary tube feet. Sometimes there are several Polian vesicles instead of one, either as an anomaly as often occurs in Cucumaria Planci or in a constant manner in the same species (see for enumeration, Ludwig, 114, p. 114).

Histology and physiology. - The Polian vesicle, as has been shown by all atuthors who have studied it, has inside and out a peritoneal epithelium, a fibrous layer, a circular muscular layer and an internal epithelium This internal epithelium, that Semon incorrectly described as ciliated, forms a nearly single layer as Hérouard describes, but in places the cells are dense. One often finds in the Polian vesicle masses of brown grnanules (products of excretion) and always a large quantity of free coelomocytes, connected by pseudo-plasmodia or isolated. In fact, as I showed for the first time in 1887, the cells of the internal wall become amoeboid, separate from the others and fall into the vesicle to soon pass into the water vascular system where they are amebocytes. The Polian vesicle plays also a role, but of little importance as a reservoir of liquid in the radial water canal (Hérouard).

\section{ECHINOIDS.}

In crinoids, there is no glandular system annexed to the water vascular system.

In urchins, the arrangement is very exceptional and, to be well interpreted, requires some attention and especially the examination of a number of different forms.

In all spatangoids and in some clypasteroids (Echinocyamus pusillus), the tube feet have no glandular system (p. XXVIII, fig. 54). 
In Dorocidaris papillata, Prouho has shown that the water ring and the oral lacunar ring are intimately entangled. Moreover, the lacunar ring formed of lacunae locaed in the wall of the water ring is continuious with the tissue of the axial gland. In brief, it has a glandular structure.

The water ring lacks any particiularly glandular organ, but consequently from its intimate association with the glandular lacunar ring, diapedesis of amoebocygtes from one into the other ring is greatly facilitated. Prouho has perfectly demonstrated, following myself, that the two rings do not really communicate as one would tend to believe. In fact, other than the continuity of the characteristic epithelium of the water ring, one recognizes perfectly in sections that the contents of the two rings are completely different. Injections made with low pressure fill one of the two rings without ever passing into the other. According to the Sarassins, (159), Asthenosoma urens has an oral ring slightly similar to those of Dorocidaris. Its tissue is glandular and continuous with that of the axial gland.

I have found in a clypasteroid Peronella orbicularis, a spongy ring identical to that of Dorocidaris. The lacunar ring (pl. XXIX, fig 63) is formed of a glandular cushion all around the esopohagus. It is filled with small alveoli with nuclei, recalling completely those of the axial gland, with which its tissue is moreover perfectly continuous. The water ring is intimately associated with it. It has on its periphery diverticula lined with epithelium that sinks into it and even ramifies into the spongy ring.

I naturally have not been able to make injections into this species preserved in alcohol, but it is quite probable, and sections sufficiently show it, that, as in Dorocidaris, the mixing of the two rings permits diffusion and especially facilitates diapedesis, but that there is no direct communication of the liquid contents.

In another clypeasteroid, Echinodiscus biforis, the spongy ring is differentiated a little more and approaches that in most regulars. The oral lacunar ring, instead of being glandular around its periphery, has some spongy bodies, irregular, projecting, located in the interradii. For the rest of its path, the lacunar ring is completely free. The water ring, at the level of these spongy bodies, sends diverticula that penetrate into their mass, just as in Peronella. It is quite certain that the two rings do not communicate because the respective contents are very different.

In echinids, each interradius has a well defined spongy mass (pl. XXVII, fig. 53), that is improperly called the Polian vesicle $\left({ }^{32}\right)$. We know that the two oral rings, lacunar and water, send small branches that are ramified to their interior without mixing (Kœhler). Horizontal and vertical sections show that these spongy vesicles are slighty similar to those of Echinodiscus. They are covered by a membrane that surrounds all the masticatory apparatus and goes to fuse with the esophageal wall. The glandular part (Teuscher, Kœhler), formed by many meshes of connective tissue, enclosing numerous nuclei and often with products of excretion (yellow granules), is identical in brief to the tissue of the axial gland. The glandular zone, thicker on the part turned towad the apex, is part of the lacunar ring. Injections made into the latter enter the interior of the fibrous meshes where we find sections of characteristic coagulum. The water ring from its side sends closed branaches, covered interiorly, at least at the origin, with a very clear epithelium. They ramify between the meshes of cellular tissue. When an injection is made with little pressure into the rings, the colored liquid does not penetrate far into the Polian vesicels and never mixes with it. To the contrary, when one increases the pressure, the injected liquid completely fills the vesicle, making clear the fine walls of separation, and passes indifferently into the other ring (Kœhler). In the echinids studied, the lacunar ring has only these five glandular masses. Its surface is perfectly free $n$ othe entire periphery. The functions of these sponogy vesicles are evident. In addition to

\footnotetext{
${ }^{32}$ Tjeu were first described by Valentin and it is, I believe, Teuscher who first called the Poli'sche Blasen.
} 
diffusion that occurs at this level between the water vascular and lacunar systems, they also provide entry to amoebocytes into their cavity either directy or by diapedesis.

Prohou (1886-87) proposed to call the Polian ring the ensemble formed by the lacunar and water rings of Dorocidaris to indicate that it is "made up on its entire periphery a Polian vesicle". Perrier (1888) associates the "Polian vesicles" of urchins with the Tiedemann bodies of asteroids and consequently called them Tiedemann vesicles or plastidogenes. The oral lacunar ring is designated as the ring of Tiedemann. Kowalsky (1889) also gave them the name of Tiedemann bodies.

These designations seem very inappropriate. Prouho has moreover recognized, like Carl Vogt and Yung, that the "Polian vesicles" of urchins do not correspond in any way to the Polian vesicles of holothuroids and asteroids that are only related to the water ring while the "Polian vesicles" of urchins come from a differentiation of the lacunar ring, originaly glandular on the entire periphery. The same observation applies a fortiori to the homology with the Tiedemann bodies (asteroids), always arranged in pairs in the interradius, and uniquely in relation with the water ring. The observation of Semper, who was successful in injecting the Tiedemann bodies of Pteraster by way of the axial sinus, proves nothing at all, if it is true. The injection could pass by the stone canal. The oral lacunar ring, whether is is glandular or not, can keep its name as "Polian vesicles" only by maintaining a regrettable confusion. They should change its name. We shall henceforth call them spongy bodies.

\section{OPHIIUROIDS.}

The Polian vesicles reappear in ophiuroids. There is generally one per interradius, except in the interradius of the stone canal. In Ophiactis virens, to the contrary, there are two, three or four per interradius (Fœttinger has reported only two) both in those with stone canals as well as in others. They are connected to the water ring by a very narrow hollow pedicle (pl. XXIX, fig. 61).

Their histology is very simple: a peritoneal epithelium, a layer of fibrous tissue (fibrils and fundamental substanace), a layer of circular muscular fibers, lacking in Amphiura, Ophiactis, Ophicoma scolopendrina, well developed in Ophiohrix fragilis, Ophioglypha albida), and an internal cellular covering. As in holothuroids, the latter appears to be formed of a single layer of cells. In places are small masses ready to be detached. In the cavity of the ampulla are always mature amoebocytes, ready to move into the water vascular system. The Polian vesicles of ophiuroids are, in fact, lymph glands as I reported in 1887 (28, p. 76). Those of Ophiactis form both amoebocytes and red blood cells.

I have been able to follow its development in embryos of Amphiura squamataa: the Polian vesicles appear as hollow diverticula of the water ring covered interioraly with the same epithelium of the ring. Later this epithelium differentiates to fulfil its special functions.

\section{ASTEROIDS.}


In asteroids, the glandular ring has several glandular attachments: the Tiedemann bodies in all species, located in pairs in the interradii and the Polian vesicles, single or mutiple that one finds in astropectenids, culcitids and asterinids.

The histology of the Polian vesicles is nearly the same as in the preceding groups, except that the muscular layers are more developed and the internal covdering has the form of a fibrous maze with included cells. The Tiedemann bodies are formed by a mass of hollow tubes opening into the water ring, whose cubic epithelium detaches to form amoebocyges as Hoffmann was the first to suggest. I have described in detail these glands in my work on asteroids. I ask the reader to refer to it for a more compete study (28).

$\delta$ In summary, extant crinoids, spatangoids and some clyperasteroids excepted, the water ring is always in relation to the lymph glands, either that they are part of it (synaptids, holohturoids, ophiuroids, asteroids), or that it sends diverticula to facilitate diapedesis into the glands dependent from the lacunar ring (gnathostome urchins). The Polian vesicles of synpatids probably have been transmitted to holothuroids, but it probable that those of asteroids and ophiuroids have no phylogentic relations with the first and that they have an independent formation as is shown by differences in number and position.

History. - The Polian vesicles of synaptids, holothuroids, ophiuroids and asteroids have always been considred as reservoirs of water vascular system fluid. I believe I was the first to have attributed to them the role of lymph glands. Hérouard has accepted this point of view for holothuroids (1889).

The spongy bodies of echinoids (Polian vesicles of some authors) have been interpreted as reservoirs by Teuscher, as excretory organs by Kœhler (who has certainly recognized their identity of structure with the axial gland) and as respiratory organs by Hamann. Kowaleskey (1889) attributed an excretory role to them according to his experiments. Their function is the same as that of the axial gland, of which they are moreover an extension.

For the Tidemann bodies, Hoffmann was the first to suggest that the amoebocytes of the water vascular system develop in their interior. Ludwig and Hamann have nearly accepted this point of view. In 1887, I supported the position of Hoffmann by showing it was the internal epithelium of the tubes of Tiedemann that are detached to form amoebocytes.I recall for the record the opinion of Krukenberg who saw in the Tiedemann bodies of Astropecten aurantiacus organs producing enzymes (pepsin and diastase). These enzymes would pass into the coelomic cavity and then would be absorbed by the digestive tube. I must ackowledge that I have not tried to verify thse assertions that appear very remarkable. Kowalsky (1889) has attributed an excretory fuction to these organs, based on their avidity for various colored material injected into the water-vascular system.

\section{DEVELOPMENT AND HOMOLOGY OF THE MADREPORITE.}

In all echinoderms, the water-vascuar system opened originally to the exterior by a singe pore. In Echinocyamus pusilus, most ophiuroids and some elasopods, this is the definitive stage. In some elasipods and ophiuroids, urchins and asteroids, the pore is transformed into a madreporite, a complex ensemble of canals and pores corresponding to a singe stone canal.

My observations on the development of the madreporite agree with those of Lovén and A. Agassiz: the pore, after having crossed the integument, is slightly dilated to be continuous with the entercoel and the stone canal. From this dilated portion leave canals that perforate inside and out 
the calcareous wall that opens to the exterior. These canals multiply little by little, anastomosing and ending to form the complex ensemble known in the adult. Consequently, in the middle of the numerous pores of a madreporite, there is one that should represent the first opening formed in the embryo.

Perrier, afer his observations on young Asterias spirabilis, describes the formation of the madreporite otherwise: the original pore has folds on the surface that form tubes in the deep part. Then thse folds connect little by little the interior to the exterior to form separate canals. In this point of view, a madreporite would thus be formed by division of a single pore throughout its length. While waiting for Perrier to pubish supporting figures, I can only refer to that I described above.

Is there a need to establish a homology between perforated calcareous plates or the madreporite pores? Ludwig once tried it without success. The pore is always at the beginning pierced in the soft integument (fixed stage in elasipods). It is only secondarily that an interradial calcaroues plate comes in contact with and completely surrounds it. We easily understand that this plate cannot be the same in the various echinoderms. It is that which is formed nearest the pore that mechanically surrounds it.

In Antedon, it is one of the oral plates that surrounds the first pore. In its migration towads the mouth, the pore, originally on the aboral surface, ends up in the interradius of the oral surface.

In urchins, the original pore is enclosed by a basal. As the basals are at the apex, we conclude that the stone canal extends in a nearly straight line from the mouth to the aboral side.

In ophiuroids, as shown by H. Carpenter, Sladen, Bury etc., contrary to the opinonn of Ludwig, the orginal pore on the aboral surface (fig. 25, pl. XXV) is surrounded by oral plates and moved by the migration of these plates to the oral surface, very near the mouth ${ }^{33}$.

In asteroids, to the contrary, it is one of the basals that is transformed into the madreporite. This plates is at the periphery of the disk on the aboral surface (extant asteroids, fossil Paleaster and Palasterina). In some palaeozoic astroids, the madreporite moves towards the oral suface, approaching more or less the mouth. This is the case in Aspidosoma, Cheiropteraster, Palasteriscus, Echinasterella, Helianthaster rhenanus (Stürta. 177).

The extension of the madreporite varies greatly. In asteroids, the madreporite pores remain located in the large basal CD. It is not the same in urchins: in the endocyclic regulars, Collyritides and exocyclic Ananchydæ, the pores are generally bordered by the basal CD, but they leave it easily: the three basals BC. CD. DE of Micropedina Cotteaui Coq. (Cenomanien) are filled with pores. It the same for the five basals of Discoïdea cylindrical and infera (Cotteau, Peron and Gauthier, Duncan and Sladen). In Echinoconus and extant spatangoids, they escape the dorsocentral plate and often even the other basals (Echinoconus, Holaster Munier,-Chalmas, 132), exceptionally the terminals (anomaly reported by J. Lambert ${ }^{34}$. Hemipneustes has pores on two of four basals and all three terminals C, D. E (Munier-Chalmas). There are also in this respect numerous variations and individual anomalies. We know that in clypasteroids (Clypeaster, Laganum, Peronella, Rotula etc.) the entire calyx, dorsocentral basals and termials are filled with madreporite pores. Finally, it occurs sometimes that the pores leave from the calyx and establish themselves on the coronal plates. Lovén has figured some specimens of Brissue canariensis

\footnotetext{
${ }^{33}$ According to Wright, Protaster Miltoni Salter (palaeozoic ophiroid) has a madreporite plate on the dorsal side. This fixed stage in the type is only transitory in extant ophiroids. But it is not certain that this Protaster is truly an ophiuroid.

${ }^{34}$ Note on a case of monstrosity of the apex of Echinocorys vlgaris, Bulletin de la Société des sciences de l'Yonne, $1^{45}$ semestre 1890.
} 
Haeckel, Spatangus purpureus and Brissopsis lyrifera, in which a small number of pores go beyond the dorsocentral onto the first plates of interradius AB (188, p. 75). Ch. Janet and I described and figured (34) a specimen of Arbacia punctulata Desmoulins (South Carolina) ${ }^{35}$, which has the highest known escape. Not only are the basal CD and the adjacent two terminals C and $\mathrm{D}$ filled with pores, but the adjacent first five interambulacral plates also have a large number.

\section{MULTIPLICITY OF STONE CANALS AND MADREPORITES}

Originally echinoderms had only one stone canal, but in many species, as a consequence of secondary adaptatons, a more or less large number of stone canals have formed beside the first that obviously have neither the same morphological value nor the same origin as the primary canal but that are made up in exactly the same way.

In holothuroids, there are often numerous stone canals attached to the water ring that all end in the coelom by a small madreporite. It is probable that all these tubes primitively had an external pore, as Selenk showed in Cucumaria Planlci (162, taf. 23, fig. 24). But no one has closely followed their development.

In extant crinoids, the number of stone canals is never less than five, one per interradius (extant Rhizocrinus lofotensis, fossil Actinocrinus vernewilianus). The number remains small in Hyocrinus, Holopus and Bathycrinus (H. Carpenter), but becomes very large in Antedon, Actinometra and Pentacrinus (more than 1500, Ludwig). We know the stone canals in the latter open freely into the coelom. The only difference with holothuroids is that in them the external pores have disappeared while they persist in crinoids. Probably as a consequence of an acceleration of development, the calycinal pores (except the first) form independently of the stone canals of the oral ring.

In urchins, as in the hexamerous or tetramerous monstrosities and whatever the number of madreporites, there is never more than one stone canal. The supplementary madreporite, found by Haacke in interradius DE of eight species of Amblypneustes (regular echinid) is very probably due to an anomalous extension of the water pores and proves only that there is a duality of the tube.

In asteroids and ophiroids, although one is the most frequent, there are numerous species that have from 2 to 5 , of even more stone canals. Sometimes they are normal and, as in holothuroids and crinoids, one can find no reason for the multiplicity. But very often they coincide with an anomaly that makes their distribution very interesting to study. The normal types with five arms and several canals are, in brief, not very numerous. Trichaster elegans (Ludwig, 99) has five stone canals. It reproduces in euryalids, the case of Rhizocrinus in crinoids.

$1^{\circ}$ The number of madreporites has no regular relation with the number of arms, no more in species that have normally more than five than in the monstrosities of pentarradial species. Sometimes it is necessary to recognize that often variable ray number (either normal for a species or anomalous for an individual) is accompanied by an anomaly in the number of madreporites.

Asteria capensis Ed. Perr., that has 5 or 6 arms, has 3 madreporites. Asterias polyplax, whose number of arms is variable, has 1 to 5 madreporites (Perrier). Echinaster eridanella with 5 arms has only one plate. When they have 6 or 7 arms, there are 2 madreporites (Müller and Troschel, Perrier). Ophidiaster with 6 or 7 arms has two madreporites (Lütken). Ophidiaster Germani Ed.

\footnotetext{
${ }^{35}$ The specimen is part of the collection Ch. Janet at Beauvais (Oise).
} 
Perr. with five or seven arms also has two of them. Acanthaster echinites and Ellisii that have 11 to 20 arms have from 5 to 16 madreporites (Lütken), etc. Couch has described a specimen of Asterias rubens with 8 arms and 3 madreporites. Giard has stated several six-armed Asterias rubens had two stone canals in the same interradius. I have found at Banyuls an abnormal specimen of Asterias glacialis with six arms and two very separated madreporites and two stone canals contained side by side in the same axial sinus, with a single axial gland. An abnormal specimen of Asterina gibbosa (Banyuls) with seven arms (of which one did not go to the mouth) had two madreporites and two stone canals placed in opposite interradii.

In contrast, Asterias Rudolphi and Vancouveri Ed. Perr. have 6 or 7 arms and only one madreporite. Likewise, Brisinga coronata Sars has 9 arms (Ludwig), Solaster, Heliaster and Luidia have numerous rays and only one madreporite ${ }^{36}$.

$2^{\circ}$ Species reproducing asexually by schizogony - As Lütken was the first to note, all these species have multiple stone canals. At least up until now we have not cited a verified exception to this rule.

Ophiactis virens, that reproduces by median division and that never has more than six arms, has 1 to 5 canals (reported by Simroth). The number seems to increase with age: Indeed, in the largest $(\mathrm{D}=2 \mathrm{~mm})$, with mature gonads, there are up to five. All of the interradii except one have some. We have not examined in this regard other ophiuroids that reproduce by division.

Asterias tenuispina (Mediterranean), which also reproduces by median division, has seven to nine arms. Individuals that are dividing often have only one madreportie, but it immediately forms one or two new plates in the regenerating part, always with 2 or 3 madreporites.Stichaster albulus (Ast. problema) that is in the same condition also has 2 madreporites (Lütken). Asterias calamaria with 6 to 12 arms have up to 4 madreporites. Perrier noted that most individuals with 7 arms have only one plate (141, p. 308). Cribella sexradiata that also seems to be dividing has 6 arms and 2 madreporites.

We have no details on the number of madreporites in other species dividing by median division (Asterias acutispina, macrodiscus, atlantica and Asterina Wega). In the latter species, the specimen I examined that had just divided (figure in 28) has only one madreporite.

Species that reproduce by radial division (comet form) likewise have several madreporites (Lütken, Haeckel). Linckia diplax, ornithopus, multiforis, Ehrenbergii and Guildingii ordinarily have 2, sometimes 3 plates although the number of arms is most often 5 .

$\delta$ In asteroids and ophiuroids, there is thus no fixed relation between the number of arms and that of the canals, although normal or abnormal irregular ray number coincides most often with the presence of several stone canals. A single fact seems constant, it is the multiplicity of canals in the species that reproduce by division (at least in complete individuals). I have studied the organization of these canals in Asterina tenuispina, Ophiactis virens and several abnormal species of pentarradial species. I have been able to confirm that they are identical to the first stone canal. It is very unexpected because they together do not form at the expense of the same parts. Before opening outside, the stone canal connects as usual with the enterocoelic sinus that surrounds it. This, connecting above with the oral schizocoilic ring, below with the aboral ring that goes to the gonads, encloses a normal axial gland.

\footnotetext{
${ }^{36}$ I have found in the collections of the Faculty of Sciences of Nancy, a Heliaster Kubinjji Xantus (from Mazatlan) with 22 arms and two, nearly equal madreporites in an interradius. Each of the two opens into a stone canal. The two canals are united in the same axial sinius, as in the abnormal specimen of Asterias glacialis cited above.
} 


\section{PHYSIOLOGY OF THE STONE CANAL}

The exact functions of the stone canal and the exterior opening are still very controversial. The predictions based on the anatomical findings are not always in agreement with experimental results. I believe it is perfectly useless to connect the stone canals to other very different systems. Among others, the homology with nephridia, indicated by Hartog (72) and nearly accepted by Bury, seems to me without any foundation. The canal and its pore are a special formation in echinoderms, as the dorsal pore of Balanoglossus, the dorsal pore of oligochaetes and others.

We set aside the holothuroids and crinoids to focus on the normal forms, urchins, ophiuroids and asteroids. Do the cilia of the madreporite and the stone canal determine the current? If there is one, is this current directed from the interior to the exterior (exhalant current) or to the contrary from the exterior to the interior (inhalant current)? Finally, what can be the function of such an arrangement?

A. A priori, it is certainly probably that a canal covered its entire length with cilia should have a current of liquid, but it is not easy to confirm experimentally. Perrier has tried without results with Echinus sphara (1875) and more recently with Solaster papposus (1890). My experiments with asteroids (1877) and those of Prouho with Dorocidaris (1888) have given negative results. Moreover, because the water vascular system is closed, the entering current should be accompanied by an exit current and vice versa, something completely unacceptable. Thus, in the normal state, there is not a continuous current demonstrated experimentally. This conclusion seems to me completely indisputable.

B. With this accepted result, it is quite natural to remove the water vascular system and to make experiments on it alone (with its madreporite) thereby to open it at its two ends. This is what Hertog (72) and Ludwig (116) tried. Ludwig (1890), who worked with various species of asteroids and urchins, says he clearly proved a current from the outside to the inside (inhalant current) of small colored particles entering the madreporite pores and leaving by the cut end. As a result, in the intact animal, the cilia tend to produce a current from the outside to the inside, a current that is without effect because the water vascular system is filled with liquid. I completely agree with this point of view as do most authors. As Perrier (1888) pointed out, the arrangement of the madreporite canalicules is absolutely that of an inhalant system, the diameter decreasing from outside to inside. In sections, we can note that the stone canal contains neither coagulum nor blood corpuscles that are so numerous in the rest of the water vascular system. This shows well that the liquid it contains tends to repel the liquid in the water vascular system and not to mix with it. The best demonstration of this is furnished by Ophiactis virens. In this species, the water vascular system is filled with red blood cells appearing injected naturally into the sections. There are never red blood cells in the stone canals, although they open into a large canal in the oral ring. These examples show in a positive fashion that the pressure of the stone canals is directed from the outside to the inside.

Hartog has made exactly opposite conclusions. For him, the current is exhalant. This opinion, that repeats the theories Perrier gave in 1875, those of Williams, Kohler and Hamann have been accepted nearly comply by Bury and the Sarasin cousins. It is however not sustainable. The anatomical arrangements and the diverse reasons I have given above, speak very strongly against them. As for the experiments of Hartog, they have been sufficiently refuted by Perrier (147), myself (30) and Ludwig (116), so I shall not discuss it further here. The fact that particles in suspension in the water are repelled when they approach the ciliated pores (Hartog, Bury), does not indicate at all the presence of an exhalant current, but is evidently the result of the presence of 
cilia. The beat the water in a way to direct the pressure towards the interior, completely preventing the solid bodies from entering into the madreporite. In fact, whatever the conditions in which we place the animal, the stone canal never contains either infusorians or particles although the surrounding water is full of them.

In summary, here are the facts that appear to me well established on the subject of the stone canals:

$1^{\circ}$ The beating of the cilia produces a pressure from the outside to the inside.

$2^{\circ}$ There is no, in the normal state, any detectable incurrent in spite of the action of the cilia because the water vascular system is closed.

$3^{\circ}$ The cilia of the pore openings are arranged so that they repel all suspended particles in the water and prevents obstruction of the stone canal.

C. If these conclusions that I have just listed are nearly indisputable, it is less easy to interpret and deduce from them the physiological role of the stone canals. In this chapter we are entirely reduced to hypotheses:

$1^{\circ}$ As the stone canal always connects with the axial enterocoel (cavity of the axial gland of urchins, axial sinus of asteroids and ophiuroids), it is probable that it plays a role in respiration and excretion of the axial gland by the means of currents of diffusion that are produced at the opening of the connection. The proposal is nearly demonstrated by the very interesting case of Spatangus purpureus (Prouho, 151). The stone canal disappears shortly after its connection with the cavity of the axial gland so that it can be considered as directly emptying into the outside. We understand that in this way the gland can easily eliminate gaseous or salt wastes. But it is important to remark that there is no continuous current in the sinus enterocoel, no more than in the stone canal. There are only simply currents of diffusion, too weak to entrain suspended amoebocytes in the axial sinus.

$2^{\circ}$ The role of the stone canal, considered in itself, is still very hypothetical: It insures the continuous turgidty of the water vascular system. In fact, when an arm of an asteroid is detached from the animal (and consequently lacking the stone canal), we see that the tube feet and their ampullae deflate little by little even though the valvular apparatus prevents complete loss of liquid by the radial canal. It is probable that the internal liquid, compressed by the muscles, tends to escape across the wall in order to balance the exterior and interior pressures. In this way there would be a slight but constant loss as one would suppose, which it or the stone canals would remedy. We have seen, in fact, that in their interior, the pressure is directed from outside to inside. This constant import of liquid, too minimal to be detected experimentally, counterbalances the constant loss that occurs by the tube feet. This hypothesis is very reasonable. It agrees well with the fact that we have reported above, the increase in number of stone canals in species that reproduce by division. It is natural, in order to counterbalance the inevitable loss resulting from ruptures, that there develops in these species a greater number of compensatory systems. In contrast, the case of the spatangoid is more difficult to explain.

It would not be difficult to make decisive experiments on living animals along the sea. One could occlude the madreporite pores with cement and observe the result for an asteroid or urchin.

$3^{\circ}$ Finally, it is not impossible that in urchins, the stone canal can have some role in maintaining the internal pressure during spawning or absorption of large quantities of food (see hydrostatics).

Crionoids. - In the absence of conclusive experiments, it is difficult to make anything other than hypotheses on the role of water in the physiology of crinoids. I also make no precise opinion in this regard. However, it appears doubtful to me that the organism has a constant current of water 
as in sponges. In fact, in crinoids as in other echinoderms (in which such a current certainly does not exist), there are blood cells, products of waste in the coelom, a lacunar system with contents very rich in albumen, etc. There is no difference in this point of view of the internal medium between Antedon and any other echinoderm.

I thus do not believe in the circulation of water in crinoids. However, the ciliated pits produce a current of water, exhalant according to Hartog, inhalant according to Ludwig. The anatomical arrangement, as pointed out by Perrier, supports the inhalant current hyopothesis that is accepted by most authors. The stone canals, which freely open into the coelom, can certainly play a role in maintaining the turgidity of the tube feet.

Holothuroids and Synpatids. - In holothuroids and synaptiids, the stone canal opens freely into the coelom by a more or less complicated madreporite. This is no question of the introduction of sea water as in urchins, ophiuroids and asteroids.

The stone canal constantly maintains the equilibrium between the coelomic liquid and the liquid in the water vascular system. It is the site of a very active inhalant current directed from its free end towards its point of reaching the ring. In fact, one finds in sections, and especially around the madreporite.amoebocyte masses entrained by the ciliary current. In Cucumaria Planci, the red blood cells of the coelomic cavity pass in more or less large numbers into the water vascular system, probably by means of the stone canal. Finally, Ludwig (116) has shown experimentally the direction of the inhalant current, and I can confirm his observations for Cucumaria Planci.

It is obvious that the conclusions that we have adopted on the subject of the role of the stone canals are in all ways applicable to holothuroids and synaptids. Only, instead of exterior water, it is the coelomic fluid that is propelled by the cilia and that maintains a sufficient pressure in the water vascular system.

If the stone canals can provide passage to an inhalant current, the inverse does not take place. In fact, although it has no valvular arrangement at the two ends, one knows that liquids injected into the water vascular system rarely goes outside, except with an exaggerated pressure (Romanes and Ewart, Cuénot, in asteroids; Hérouard in holoothuroids, etc.). It is probable that blood cells, introduced by injection, form plugs in the madreporite canlicules and prevent exit of the liquid. When the oral ring is filled with liquid, as a consequence of the contraction of the Polian vesicles, for example, it does not leave by the stone canal. These observations confirm absolutely the hypotheses that we made previously.

\section{WATER VASCULAR SYSTEM OF OPHIACTIS VIRENS.}

We need to study completely separately the water vascular system of Ophiactis virens that shows a large number of exceptional peculiarities. This small ophiuroid, very abundant in some bottoms in the Gulf of Naples, divides as we know by median division. Ophiactis has six arms instead of five. Simroth has devoted a special monograph (1876) of rare accuracy. But at the period he made the study, normal ophiuroids were too poorly known for him to give an account of the differencs. Foettinger (1880) discovered blood cells with hemoglobin in the fluid of the water vascular system. Other authors, notably H. Carpenter, Ludwig, Apostolidès. Hamann and Preyer have also spoken of Ophiactis, but especially to attack the conclusions of 'Simroth and Foettinger that did not appear to them to be compatible with the results obtained with normal ophiuroids. In summary, the study of this species needs to be nearly entirely repeated. 
Anatomy of the water vascular system. - We shall study first an adult Ophiacatis virens, whose disk is approximately $4 \mathrm{~mm}$ in diameter. The gonads are well developed and fill the interradial pouches (two testes or ovaries per interradius, pl. XIX, fig. 59). The oval water ring, larger than usual, has many diverticula: $1^{\circ}$ several stone canals (five in the specimen I am describing). $2^{\circ}$ Six radial canals. $3^{\circ}$ In each interradius are multiple Polian vesicles. $4^{\circ}$ From ten to fifteen long vessels that bypass the digestive tube or are lost in the midst of the gonads. All this system (except for the stone canal) is filled with blood cells with hemoglobin, lacking nuclei, accompanied by some amoebocytes. Thanks to this kind of natural injection, one can easily follow the small canals in the sections.

$1^{\circ}$ The number of stone canals increases with age. In the youngest individuals, I have found only one. In three others, two canals in adjacent interradii. Finally, in an adult, five canals. They are all alike. The stone canal, covered with a characteristic ciliated epithelium, opens at its distal end into a very complicated ampoule with a squamous epithelium (diverticulum of the axial sinus enterocoel). This ampoule gives off a short canal with a ciliated epithelium that opens on one side of the interradial pouch. These relations were certainly seen by Simroth, although they were later misunderstood by Ludwig and Hamann.

The axial sinus enterocoel that surrounds each stone canal encloses a rudimentary axial gland that Simroth did not see, but which has all the usual connections. We shall return elsewhere to this point, concerning the glandular system.

$2^{\circ}$ The six radial water canals, with a diameter larger than usual, extend into each tube foot ossicle transverse canals in the from of a very narrow $\mathrm{V}$ that lead to the tube foot covered with sensitive mamelons (Simroth). At the point where the transverse canal opens into the tube foot, is a small normal valve.

$3^{\circ}$ The number of Polian vesicles is very variable. There are usually more than two (Foettinger) or three, that can fuse with each other in such a way that they do not have, so to speak, a definite form. Some rest on the ring or they are connected to it by a more or less long peduncle (pl. XXIX, fig. 61). The presence of the stone canals does not result in, as usual, the suppression of the corresponding Polian vesicle. There is an equal number of them in the different interradii. The blood cells and amoebocytes of the water vascular system are formed in the Polian vesicles. They are also filled with red blood cells in process of development. Cells with very large nuclei are found on the wall of the cells that are evidently the origin of amoebocytes. Finally, there are always in the vesicles a quantity of of more or less large, yellow, irregular granules that are the products of excretion as in the Polian vesicles of holothuroids.

$4^{\circ}$ From the oral ring and even the peduncle of the Polian vesicles are detached in each interradius some small hollow canals, long and bending, go towards the periphery of the disk and end in a caecum. There are six to fifteen. In young individiuals, while the the gonads are not yet developed, many of them go to the digestive sac and extend onto its surface without however reaching the aboral surface. The other vessels, very bending, simply cross the cavity of the bursae and end in any point. The number of these canals seems to increase with age. In large specimens, with ripe gonads, there are many at the surface of the digestive tube, located in all the folds of the membranes. The gonads (pl. XXX, fig 59) develop between the vessels that we have seen are freely extended into the bursae.

The structure of the canals is very simple. Their wall is a thin connective membrane, covered exteriorally with the peritoneal epithelium and interiorally with small flat cells (ciliated?). They are filled with red blood cells mixed with some amoebocytes. 
Physiology and morphology. - The canals that we just described, in relation with the digestive tube and the gonads, have been reported by Simroth (169) under the name "Wassergefässe der Bauchhöhle (Vasa ambulacrala cavi)". Their significance has greatly intrigued authors. Simroth related them to the Tiedemann bodies and Polian vesicles of asteroids and regarded them as very elongated glandular appendges that probably would form the structured elements of the water vascular system. H. Carpenter (19) had previously compared them to stone canals of crinoids, likewise appendages of the water ring. Ludwig (107) resumed the hypothesis of Simroth and homologized these vesicles with very elongated Polian vesicles. Apostolidès denied their existence (5) without having examined Ophiactis.

To better understand their importance, it is necessary to refer to the physiology of Ophiactis. As one knows, this species has a high degree of schizogonial reproduction by median division. It is this process of reproduction that should be attributed very probably the disappearance of bursae. In fact, these, so prominent a characteristic of ophiuroids and euryalids is totally lacking in Ophiactis virens. Their delicate wall would inevitably be torn with the separation of the two halves, and one knows that, in normal ophiuroids. the animal dies rapidly when it establishes in this way communication between the ambient environment and the coelomic fluid.

Because of the disappearance of the bursae, we can expect that their usual function, i.e., respiration, is attributed to another organ. It is in fact to the water vascular sustem that takes this role. On one hand, it is filled with red blood cells with hemoglobin that binds with oxygen. On the other hand, it gives off vessels (vasa ambulacralia cavi) that goes to distribute oxygen to all the body regions: coelom, digestive tube, and gonads. It is natural to find numerous Polian vesicles because the number of corpuscles is much greater than usual.

Although there is no heart annexed to this singular water vascular system system, the corpuscles it contains are constantly in movement because of the contractions of the body and especially the presence of cilia. In the extended tube feet, the corpuscles have a strong gyration produced by internal cilia. In spite of the presence of the valve, it is quite probable that it should have there a continuous influx of new blood cels and a corresponding exit current. In the vessels coming from the water ring, as Fœttinger noted, the corpuscles are moved constantly back and forth Oxygen could thus move by degrees from the tube feet where is is taken up from the external environement up to the last ends of the vessels. From there, it passes into the coelomic fluid, the walls of the digesive tube and the gonads. One sees thus that for us, contrary to the opinions of the authors cited, the water vascular system is highly modified in Ophiactis virens, filling the respiratory functions in place of the bursae that are missing in this species. Perhaps it also has a role in absorptin (by the canals of the digestive tube) and the nutrtioin of the tissues it passes? It is very probable, although in the other ophiuroids, it is especially the coelommic fluid that is the pathway of nutritive albuminoid bodies ${ }^{37}$.

I do not know at this time of studies on the other species of ophiuoids (Ophiactis, Ophiocnida, Ophiothela, Ophiocoma) that also reproduoce by median division. It is possible that there also is in these species a special differentiation of the water vascular system.

\footnotetext{
${ }^{37} \mathrm{~A}$ fact that I must note is that one often finds in the coelom or even in the interior of the tissues, some red blood cells (in small number) completely like those of the vessels. It is improbable that it is by accident of preparation, because I have confirmed it in total sections of individuials of different sizes. Is there a normal dipedesis across the walls, or would it not be instead at the moment of schizogonial division that the red blood cells can move out of the vessels.
} 


\section{CAVITIES OF IRRIGATION}

The cavities of irrigation in relation to the nutrition of organs are very complex in echinoderms. This makes their study still more difficult. There is no known formation to which one can compare them. The lacunar system, with its ramifications and capilliform lacunae, do not correspond at all to a vascular or circulatory system, because there is no propelling organ, heart or cilia. The intermixing of this system with the frankly glandular parts that produce amoebocytes or give rise to the gonads only add to the difficulty.

In each class we shall study separately:

$1^{\circ}$ The cavities of schizocoelic origin, in regard to the nutrition of the neural centers of the oral surface, comprised of a ring and five radial sinuses. These more or less developed cavities exist in all echinoderms and it is very probable that they have been inherited from one group to another.

$2^{\circ}$ The cavities (other than the coelom) of enterocoelic origin, well defied only in the urchins, ophiuroids and asteroids. This system is in relation with a lymph gland (the axial gland) and the gonads originating more or less directly for the latter. In asteroids and ophiuroids, this enterocoelic system connects to the schizocoelic system in a way to form an inseperable ensemble.

$3^{\circ}$ The lacunar system, well developed only in synaptids, holothuroids, urchins and crinoids. It contains an absorbing system that receives products of digestion and the network that distributes them to the gonads, certain glands (axial organ of crinoids, axial gland), and to the radius (radial lacunae). In ophiuroids and asteroids, the lacunar system in rudimentary, there no absorbing lacunae at all. I think that the lacunary system is formed independently in each class, there has not been an inheritance from one type to the other. This wold explain the numerous differences in position and development.

\section{SYNAPTIDS}

In synaptids, the enterocoelic system dos not exist. In fact, it derives from the entercoelic vesicle interposed between the stone canal and the external pore. Now, the latter atrophies during the course of development (Bury), even before the stone canal opens into the coelom. We thus have to concern ourselves only with the schizocoelic and and lacunary systems (type: Synapta inharens).

Schizocoelic cavities (pl. XXVIII, fig. 52). - One can study them by sagittal sections of the radius that one can verify by transverse sections. The neural ring covers a ring cavity perfect closed that is the oral schizocoelic sinus, covdred by a squamous epithelium and often crossed by fine connective tissue strands.

The radial sinuses, likewise of schizocoelic origin, begins at contact with the ring, but are separated from the latter by a small septum that prevents all communication. Their lumen is crossed by numerous connective tissue tracts. These sinus do not extend very far. They are occluded little by little so that in nearly their entire length the nerve fibers are located between the wall of the bodies and the radial muscle with an interposed cavity. 
Lacunar system (pl. XXVIII, fig. 52). - The lacunar system is also very simple. The absorbing lacunae of the intestine is composed of two large lacunae along two opposite sides of the intestine. These two lacunae soon form only one, located in the mesentery of interradius C D.

This lacuna is very large and encloses a slightly pink liquid, very rich in dissolved albuminoids, in which are a few amoebocytes. It is limited by a very thin connective tissue layer with longitudinal muscle fibers covered with the peritoneal epithelium. Sections show it does not have a visible internal endothelium (I must say that I have not tried staining with silver). The lacunae go the length of the digestive tube and, reaching the gonads, send a large canal into their wall. It is not, however, thick. It continues go for some millimeters while gradually becoming small and ends by inserting its end into one of the peripheral tracts against the wall of the water ring exactly where the stone canal opens into the ring. This terminal part of the lacuna changes gradually in nature. From numerous connective tissue tracts it becomes filled with a very large number ofo nuclei and free cells. It is not impossible that this part is a place for the production of amoebocytes of the lacunar system.

The wall of the gonads, at the point where they have contact with the lacuna, is nearly split (pl. XXX, fig. 77). Between the internal very thin layer and the thicker external layer is a circurlar cavity crossed by connecting tissue tracts and filled (in the sections) with the coagulum characteristic of the lacunar system. This cavity extends above and below a very great distance (see the figure, pl. XXVIII, fig. 52).

We see how the lacunar system is simple in synaptids.. The products of digestion, collected by the absorbing intestines, are led directly to the gonads whose development is so great and so rapid.

The small extension that goes to be lost in the peripharyngeal tracts while taking on a glandular structure probably shows plasticity. I must note that I have only studied the lacunar system of Synapta by sections, with great care it is true. This is to say that it would be useful to verify the resuls obtained by injections.

History. - Hamann (67) appears to have seen the radial schizocoelic cavities but, by a singular error, he interpreted them as tube feet canals that opened into the five tube feet ampullae located opposite the radius. I have shown, in the chapter on the water vascular system, that the ring canal does not give off any other branch than the twelve tentacles. The radial canals of Hamann can only be the schizocoelic sinuses that, in fact, begin with slight contact with the tentacular vesicles but without any connection with them.

The intestinal lacunae have been reported by Joh. Müller, Baur, Semper, etc. Hamann studied them with care from the histological point of view. For each tentacle, he likewise shows a blood lacuna that runs the length of the internal border of the tentaclar vesicle. At their base, these twelve lacunae open into a hemal ring whose connection with the intestinal lacuna was unknown to him. (Nach dem Ringkanal zu verschmälern sich die zwölf Lankunen, uns auf der Peripherie desselben, durch eine ringförmig verlaufende Blutlakune zu kommuniciren, (67, p. 54). I have investigated with care thse so-called tentacular lacunae and I have never seen in the wall of the tentacular vesicles that can be related to the descriptions of Hamann. There is no oral lacunar ring. Semper, in exotic Synapta (168), has also described an oral ring and tentacular lacunae.

HOLOTHUROIDS 
As in the synaptids, the enterocoelic vesicle, originally interposed between the stone canal and the external pore, atrophies during development (Burry). It is probable that we will find traces of it in the elasipods where the stone canal keeps its ancestral characteristics, but this investigation remains to be done. In any case, in ordinary holothuroids, there remains no trace of this enterocoelic cavity.

Schizocoel. - The underlying schizocoelic cavities form five sinuses between the nerve bands and the water canals (pl. XXVII, fig. 39). The sinuses end in a caecum with two ends: below, in contact with the integument at the same time that the deep nerve layer disappears (pl. XXVII, fig. 41); above, where the radial bands connect to the nerve ring. This latter is completely enclosed in the tissues and is not covered by a schizocoelic ring. It is probable that the latter exists at first and later disappears.

The History of the radial sinuses, discovered by Joh. Müller, is completely treated in the work of Ludwig $(114$, p. 232) to which I refer.

Lacunar system. - The lacunar system appears to me now well known and understood in all its details. Tiedemann, Müller, Selenka, Semper, Greeff, Teuscher, Jourdan, Semon, Hamann, and lastly Hérouard have brought successively their share of discoveries. Hérouard (73) has noted precisely the relations of the differeont parts of the system. I disagree with him only for having brought together in his descriptions the true lacunar system, containing the nutritious fluid, all the permeable areas of the various organs, where migrating amoebocytes are displaced. The first has constant arrangements while the second varies greatly according to species. This is easily understood because this is a simple differentiaton of tissues that facilitate migration of reserve amoebocoytes. The union of these two parts, which can be perfectly supported from the physiological point of view, has no other reason for being, morphologically speaking, and can only lead to unfortunate confusion. I shall concern myself here only with the true lacunar system.

The intestinal absorbing areas are united in two marginal lacunae.that run the length of the intestine in two opposite generators. One, opposite the interradius CD (dorsal lacuna), much larger than the other, is connected to the gonads either directly (aspidochirotes) or by an intermediary of a genital lacuna (dendrochirotes). At the upper part, the two lacunae open into a diffuse oral ring, sunken into the wall of the esophagus and the peripharyngeal tracts (annular plexus of Théel), nearly at the level of the water vascular system. From this oral ring leave five radial lacunae located in the wall that separates the radial water canal from the radial sinus and emits laterally branches that go to the buccal tentacles and tube feet. As for lacunae of the stone canal or the Polian vesicle, (Semper, Danielssen and Koren, Tiedemann), I consider their existence improbable.

$1^{\circ}$ Marginal and gondal lacunae. - I set aside here the network of absorbing lacunae that have nearly similar arrangements in aspidochirotes, dendrochirotes and elasipods in order to carefully consider the marginal and gonadal lacunae. We find good figures in Semper (168), Hérouard (73) and Ludwig (114, pl. XI). To have complete ideas of the lacunar system, it is indispensable to study by serial sections that is tedious in large specimens. I have thus followed the path of the gonad lacuna from the gonads up to the oral ring and then up to the origin of the radial lacunae.

We take first as an example an adult Cucumaria Planci. If we open the animal in a way to show the mesentery of the interradius $C D$, we can see without preparation a large part of the lacunar system. From the oral lacunar ring, immediately below the point where the stone canal leaves the water ring, is detached a large lacuna, with thick undulating walls that follow the intestine for some millimeters, then is recurved to go obliquely towards the gonads, in the base of which it disappears. . At the base where it changes direction, it is continuous with the marginal 
lacuna of the intestine, very small and with a much thinner wall. From the opposite side of the lacunar ring is detached naturally the other marginal lacuna, with equally thin walls.

We thus see that from the oral ring to the gonads there is a complete lacuna that gives off at some point of its path the dorsal marginal lacuna. I have found the same relations in Cucumaria cucumis and Lacazii.

In Elpidia glacialis, as Théel has also shown well, the arrangements are slightly different (179). The two marginal lacunae both empty into the oral ring. From this, exactly below the water ring is detached a genital lacuna, larger than the marginal lacunae that goes to end at the base of the gonads. It is the same in Kolga hyaline (Danielssen and Koren, 36).

In aspidochirotes (Holothuria, Stichopus) there is no longer a distinct genital lacuna. The gonads being very near the intestine are vascularized directly by the marginal lacunae. As in the dendrochirotes, this is very voluminous between the oral ring and the gonadal group (pl. XXX, fig.76) to decrease volume and thickness the rest of its path.

We now go to the study of the sections, especially in Cucumaria Planci. At the contact with the gonads, the lacuna separates into small ramifications that are soon lost in the connective tissue of the walls. In a long series of sections that go to the gonads in the area of the pharyngeal bulb, the lacuna has nearly the same characaaters. Its walls are very thin and simply connective tissue. It is subdivided by small connective tissue tracts (Joh. Müller has clearly noted this plexiform structure in the gonads of Cucumaria Planci and frondosa), and contains an albuminoid coagulum with amoebocytes. This makes it easy to follow its path. Well before entering the bulb, the lacuna begins to change its nature. The connective tissue tracts increase at the periphery and is full of cells. This character increases more and more so that a little below the water ring, the lacuna is transformed into a compact true gland, very voluminous that goes into the peripharyngeal cavity. After some millimeters, it becomes very irregular, divided into small convoluted lobes ( $\mathrm{pl}$. XXX, fig. 74) and ends by mingling with the esophageal tracts, exactly at place where the stone canal opens into the water ring.

This terminal gland continues for same time to the center of the lacunar cavity filled with coagulum, but this disappears towards the upper end. The glandular part is formed of a fine connective tissue network enclosing in its mesh a large number of nuclei and cells of the same dimension as the amoebocytes of the coelomic fluid and also packets of yellow granules (waste products). It has completely the structure of a lymph gland. I have not studied it in vivo, but I consider it very probable that its function is to form amoebocytes (probably also red blood cells in Cucumaria Planci) that are released into the perihryngeal fluid and from there into the coelom.

The marginal lacuna opposite (ventral lacuna) has no glandular differentiation and is simply lost in the diffuse lacunar ring made up of the walls and radiating tracts of the esophagus.

In Cucumaria Lacazii and cucumis, there is no well developed lacunar gland. The marginal lacuna is likewise subdivided by connective tissue tracts that become a little more numerous, as well as adjacent cells towards the terminal end that are mixed with a peripharygeal tract, exactly at the point of origin of the stone canal. The glandular differentiation is infinitely less marked than in Cucumaria Planci.

In Holothuria impatiens, the arrangements are a little different. The marginal lacunae disappear at their end, nearly at the level of the water ring, in a glandular ring that surrounds the esophagus and from which leave above the radial lacunae. This circular gland, a true spongy ring filled with cells with exactly the same structure as the terminal gland of Cucumaria Plancid. It is very probable that it is also a lymph gland. The spongy ring (pl. XXX, fig. 75) emits by it external surface a number of small hollow villosities, filled with coagulum, that extends into the coelom. 
On its internal surface, it is bathed by the peripharygeal liquid. The free space found between the ring and the esophagous is crossed by peripharyngeal tracts. The cells of the ring are pressed against each other, so that is is very compact. There is also, as is the case in all lymph glands, masses of waste products.

It is probable that the spongy ring exists in other holothuroids. Jäger ${ }^{38}$ called the lacunar ring of Holothuria atra Jäg. "annulus glandularum hepatic analogus". Mertens, in Stichopus ananas Jäg.and Holothuria marmorata Jäg., described it as a glandular organ surrounding the intestine. Finally, the appendages described by Selenka in Mülleria varians (161) as small pedunculated vesicles attached to the oral ring and filled with "Fettröpchen" could well be glandular appendages with excretory products.

$2^{\circ}$ Radial lacunae - For the radial lacunae, reported by Semper, Teuscher and especially Semon, I can only confirm the excellent description by Hérouard, to which I refer (73). All along their path, these lacunae give small bundles to the buccal tentacles and the tube feet (Hérouard). It is easy to demonstrate these lacunae by staining sections with a triple mixture (see Technique). Their albuminous contents strongly fixes the orange. Under thse conditions, we clearly see that the tentacular lacunae have a very short path, to the base of the tentacle.

History. - Semper has given the best description of the lacunar sysgem of Holothuria and Stichopus. He has perfectly shown the genital lacuna in Colochirus anceps. This lacuna has also been described, more or less correctly by Tiedemann, Joh. Müller, Selenka and Hamann. Carl Vogt and Yung, in Cucumaria Planci, have completely ignored it: "this problematic canal is closed at both ends. We have found no opening, neither towards the genital canal nor towards the esophagous. We consider it as an organ in regression....etc. (182, p. 654).

Hérouard (73) says that "the problematic canal opens from one side into the external maginal lacuna of the intestine at the lower end of the stomach, while the other end narrows gradually toward the body wall, but goes, contrary to what we thought, beyond the gonads that consequently are placed in its path and not to its end (p. 117, from the separate print). It is unfortunate that Hérouard does not give more details on the path of this genital lacuna. For my part, like Müller, Semper and Hamann, I have always seen it go to the gonads and not beyond.

The glands of the lacunar system have not been reported until here by any author. However, Hérouard shows in a young Cucumaria Planci, in the angle formed by the stone canal and the marginal lacuna, "a very lacunar tissue filled with ameobocytes that could very well represent a rudimentary axial gland (73, p. 129). "But he doe not give details on the connections of this tissue.

Development of the gonads. Synaptids and holothuroids. - The gonads appear relatively late, when the lacunar system is already well developed.

In young synaptids, Semon (165) does not say much about the development of these organs. He describes them as sacciform diverticulae with a coelomic wall projecting into the body cavity and with the interior containing mesoderm cells that later become gonad cells.

Hamann (70) says nothing more about the origin of gonads. At their youngest stage, there are caeca lined interiorally with a single layer of large cells (Urkeimzellen).

According to Hérouard (78), the bud producing the gonads is formed by a mass of spherical cells located in the connective tissue of the mesentery, tangential to the genital lacuna. This large bud pushes the wall of the mesentery before it and produces the gonadal caecum whose internal cavity gradually appears.

I unfortunately have not been able to follow all the development of the gonads. The youngest stage I have encounted was in a Holothuria impatiens a third of its size (the specimen measured

\footnotetext{
${ }^{38}$ Jäger. De Holothuriis, Diss. Inaug. $4^{\circ}$ Turici, 1833.
} 
$0.085 \mathrm{~m}$ in length while the adult, according to Semper, measures 0.360 meters and according to Carus, 0.250). The gonads were already developed in the form of four or five small caeca (pl. XXX, fig. 76). The marginal lacunae of the intestine are very clear. One of them, the dorsal, has a large dilation at the level of the gonzds. It then continues along the intestine, its diameter being considerably reduced. At the interior of this dilation is found a cellular mass whose limits I could not determine. At their base, as shown in figure 76, they are surrounded by a free space (extension from the lacuna caused by the development of the caeca). The caeca are clearly limited by a thin connective tissue blade covered with a single layer of cells. There are also numerous free cellular masses in the cavity of the caeca. From the genital group leaves the excretory duct, already well defined but obstructed in large part by the cells.

Because I have not followed all the first stages, I cannot make a hypothesis. All occurs as if the initial cells of the gonads were placed in the interior of the marginal lacuna. The buds that they form develop, pushing before them the lacunar wall.

These conclusions do not completely agree with those of Hérouard. However, as a result of his description, the genital bud in Cucumaria Lacazii is in contact with the lacuna.

\section{CRINOIDS}

No longer as in synaptids and holothuroids, we do not have to concern ourselves with enterocoelic cavities annexed to the stone canals. In fact, these are mixed with the coelom.

Schizocoel. - Strictly speaking, there are only five extremely reduced radial sinuses. The oral schizocoelic ring is impossible to recognize. The sniuses are simple spaces between the water canal and the epidermal nerve band. It is necessary to have good prepartions in order to have evidence. These are, as a matter of fact, more like vestiges than functional cavities. Although their existence as normal cavities has been doubted (Perrier, Carl Vogt and Yung), it seems indisputable to me. Ludwig and H. Carpenter have seen them in Antedon, Actinometra and Pentacrinus. Hamann (71) figures them with care, and in my turn, I entirely confirm these results.

There is no internal epithelium. It is a simple schizocoelic sinus. It is wrong that Ludwig and H. Carpenter have joined them to the lacunar system.

Lacunar system. - The lacunar system is well lknown, especially since the beautiful work of Ludwig, H. Carpenter, Perrier nd Hamann. It includes a system of intestinal absorbing system, a plexus that is found around a special glandular organ (axial organ or genital stolon) and a periesophaeal ring of plexiform nature. The periesophageal ring is transformed into a lymph gland and then constitutes the spongy organ.

The axial organ, formed of coiled tubes, lined with a special epithelium and apparently containing an albuminous coagulum, produces at a young age genital cords that are located in the arms and whose later ramifcations become, in the pinnules, ovaries and testes as Perrier (145) showed. In the adult, it forms sexual cells all along the length of the cords (Urkeimzellen of Hamann) that eimigarte probably to the interior of the gonads to mature (71).

The axial organ does not have the structure of a lymph gland and moreover its cells are very different from amoebocytes. I thus believe its role can be considered as very problematic.

ENTEROCOELIC CAVITIES (URCHINS, OPHIIUROIDS, ASTEROIDS). 
Instead of studying separately the enterocoelic cavities of urchins, ophiuroids and asteroids, it is preferable to combine them in the same chapter. What is not very clear in one group becomes sometimes better in another.With the enterocoel is associated the study oof the axial organ and the development of the gonads. These have given some results so very interesting, not only for the echinodoeroms but also for general morphology.

The enterocoelomic vesicle, originally interposed between the stone canal and the madreporite, conserve the same connections in the three classes. The stone canal is near the madreporite but always keeps a more or less reduced connection with the enterocoel. We have sufficiently insisted on these facts, indicated by Bury (917) so that is not necessary to return to it. When the echinoderm separates from the larva, the enterocoelic sac extends the length of the stone canal, up to the region of the water ring. At the distal end it connects laterally with the stone canal (see the excellent figures in Bury). Now, in urchins, ophiuroids and adult asteroids, there is a cavity that has exactly the same connections. This is the axial sinus (sacciform canal, hydrophilic sac of Perier, Schlauchförmiger Kanal of Hamann), very recognizable in asteroids and ophiuroids, nearly entirely obscured by the axial gland in urchins. Although we have not rigorously followed its development, it is nearly certain that the axial sinus represents the enterocoelic vesicle of the larva. This is what Bury said: "....The same figure also indicates what I shall prove more fully in a future paper, that the left anterior entercoel becomes the so-called 'Schlauchförmiger Kanal' of the adult (17, p. 443)." In 1885, Hamann also considered his "Schlauchförmiger Kanal" as a cavity of enterocoelomic origin

As for the pulsating organ described by Metschnikoff and Bury beside the madreporite (urchins), we do not find it in asteroids and ophiuroids and we know only what it becomes in the adult.

Formation of the axial gland. - The first differentiation that appears in the axial enterocoel is the production of a glandular organ, the axial gland (Herz of Tiedemann, Centralblutgeflecht of Ludwig, colored organ, Drüsige Organ of Hamann, dorsal organ, madreporic gland of Koehler; collateral organ, plastidogen organ, axial organ of Perrier, etc.).

The authors are not very explicit about the mode of formation of this organ. Ludwig in Asterina gibbosa $(110,1882)$ says that that axial gland is formed very near the stone canal in a mesenterial cavity (Spalgtraum) (this cavity can only be our axial sinus). In all his figures, unfortunately very schematic, he always represents the gland beside the stone canal. Finally, he insists in several places on the constant association of these two organs.

Hamann $(68,1855)$, in young Asterias rubens 1 to $3 \mathrm{~mm}$ in diameter, describes the axial gland as a swelling of he internal wall of the axial sinus. This swelling is hollow and its cavity is lined with large granular cells.

Perrier $(144,1886)$, in young Asterieas spirabilis $2 \mathrm{~mm}$ in diameter, says that the axial gland "is seen as a conical lateral extension of the peritoneal membrane of the digestive tube coming from the upper part of this tube and enclosing a large number of vitellin bodies identical to those of the same wall of the digestive tube. This extension goes down the length of the tube that envelopes the hydropore canal, presses against a part of it, is enclosed in its interior and finally penetrates into the underlying peribuccal cavity ${ }^{39}$ to contribute to the formation of the chamber of this cavity,....etc.”. If I understand this description, which Perrier has not supported with figures, the axial gland is formed outside the axial sinus, against the digestive tube and latter invaginates,

\footnotetext{
${ }^{39}$ Our oral schizocoelic ring.
} 
so to say, to the interior of the enterocoel. This point, if it were well demonstrated, would have considerable interest because it would permit homologizing the axial organ of crinoids with the axial gland of urchins, ophiuroids and asteroids, a homology that I consider now as impossible to accept. In other works, Perrier appears to consider the gland to be produced "by the membrane on which it rests".

I have studied the development of the axial gland in embryos of Amphiura squamata and in the half of the disk in process of regeneration of Asterias tenuispina. I conclude from this, as can moreover be presumed from the study of adults, that the axial gland is formed in the interior of the axial sinus and results from a particular differentiation of its walls.

In Amphiura squamata measuring $240 \mu$ in diameter, there is no trace of the axial gland. The axial sinus is moreover very reduced and difficult to see well (at this stage the madreporite is found still on the aboral surface, pl. XXV, fig. 25). When the disk attains nearly $700 \mu$, we begin to see the rudiments of the organ. The axial sinus, limited by a thin connective tissue blade, encloses already the stone canal as it seems to me (pl. XXIX, fig. 64). On the internal surface of the free wall are found some mesodermal cells forming a very poorly defined longitudinal mass that is evidently the rudiment of the axial gland. This stage of development is, so to say, fixed in adult Ophiactis virens. In this species, the rudimentary axial gland consists simply of a cellular-fibrous thickening of the internal wall of the axial sinus. As we examine Amphiura more and more advanced in age, the number of these cells increases so that we soon have a glandular organ filling in part the axial sinus and covering the stone canal nearly its entire length.

In Asterias tenuispina, in the half of the disk formed after autotomy, there is always one or two newly formed stone canals accompanied by a well formed axial sinus. The axial gland is developed very early in the form of a projection from the internal wall, in which accumulate mesodermal cells. This projection increases more and more in a fashion to form a gland hanging in the cavity of the axial sinus to the wall of which it is connected by a mesenterial blade that is only the original peduncle.

Axial gland in adults. - Imagine the axial sinus and the completely developed gland, disregarding their relations to the gonads on one hand and the oral schizocoelic ring on the other hand.

A. In urchins the axial gland develops circularly and fills nearly completely sinus, especially the oral part. At the center persists a very capacious form, ending in a cul de sac from the oral side and known as the cavity of the axial gland. As we approach the madreporite, the internal cavity increases and the gland is reduced in proportion so that at the end the wall of the sinus is nearly entirely free (pl. XXX, fig. 69, 71, 72).

Under the madreporite, the axial sinus ends in a vast cavity that communicates with it in at a young age but that is separated later by a transverse septum (pl. XXX, fig. 69, 72). The axial gland penetrates into this cavity in crossing the chamber and is terminated in the form of a rounded, more or less voluminous mass attached to the wall by connective tissue strands: this is what Prouho has called the glandular process (regular urchins and spatangoides). I have likewise found it in clypasteroids where it attains a great development. The glandular process has nearly the same histological constitution as the axial gland. It is thus very probable that, as the latter, it produces amoebocyotes. The importance of the vast cavity beneath the madreporite where it is enclosed is still very obscure.

History - After the works of Hoffmann, Perrier, Kœhler, it is Prouho (151) who has best clarified the constitution of the axial gland of urchins. He has described the exact relations of the 
internal cavity, discovered by Valentin, the cavity underlying the madreporite and the glandular process. The histological descriptions are very exact.

Hamann (69) has misunderstood in part the cavity under the madrreporite with his process, although one can recognize them by a simple dissection.

The Sarasins (159) have studied the axial gland of Asthenosoma urens, but with the idea that it was an excretory organ. Consequently, the cavity of the gland becomes the renal cavity and the glandular process a "Nebenniere". Histologically, they made an error that has been refuted for a long time. They have taken for cells the small rectangular cavities resulting from the cononective tissue strands and enclosing the true lymph cells. Finally, the ciliated funnels that are enclosed in the interior of the gland are nothing other than small invaginationns of the peritoneal layer that appear to have no other function than to facilitate the diapedesis between the contents of the gland and the coelom. They have been well described by Prouho in Dorocidaris papillata. I have found then, with less development, in Strongylocentrotus lividus and Echinus microtuberculatus.

B. In ophiuroids and euryalids, the axial sinus is a slightly pyriform sac whose narrow end opens into the oral schizocoelic ring. The sinus extends into the wall of the body by a more or less complicaed ampulr (pl. XXIX, fig. 58) lined with the same pavement epithelium as the sinus. We know that this ampoule opens from a part of the stone canal that leads to the water pore. These relations, unknown to most authors, have been exactly described by Simroth in Ophiactis virens. The very compact axial gland that partly surrounds the stone canal, nearly completely filling the cavity of the sinus (pl. XXIX, fig. 57), leaving only a small free space between it and the wall. At its aboral end, its tissue becomes loose and it is attached to the integument by connective tissue strands. There is no cavity beneath the madreporite, nor a glandular process.

C. In asteroids, the axial sinus is a vast sac with resistant walls, in which are suspended the stone canal and the axial gland, leaving empty a large part of the cavity. The axial gland is attached to the wall by a mesenterial blade. At its aboral end, it ends in a long glandular process located as in urchins in a vast, entirely closed cavity (figures in 28). I have shown that the axial glands has one or two glandular extensions that enter the wall of the axial sinus to spread out in the general cavity to which they give amoebocytes. These extensions are generally considered to be vessels that go to the digestive tube (Tiedemann, Ludwig, Hamann). Only Greeff and Hoffmann suspected their glandular nature.

The histology of the axial gland in ophiuroids and asteroids is extremely simple. The gland crossed by a very dense connective tissue network with abundant amoebocytes in process of formation and dividing nuclei in its mesh. Very often, there is abundant coagulum in its glandular cavities, especially at its ends, where plastidogenesis is less than in the central part.

\section{DEVELOPMENT OF THE GONADS.}

Now that we know the general features of the enterocoelic axial sinus and the axial gland formed in its interior, it remains for us to study the development of the gonads. The investigations of Prouho, Hamann and myself do not agree in all parts. This question is very interesting because I have not examined it carefully. Despite these difficulties, I hope this time to reach a satisfactory result that reconciles for the most part the reported opinions.

ASTEROIDS. - In young asteroids, when the gonads begin to form, it appears first as an

extension of the axial gland, filled with cells slightly different from cells of the gland. This 
extension, or genital cord, is covered with a pavement epithelium, pushing before it in its development the wall of the axial sinus. These two parts, cord and sinus, go around the aboral surface, producing in each interradius two branches on which bud the gonads. This results in a great growth of the cord, enveloped as always by the peripheral enterocoelic sinus. The sexual cells are nothing other than the lymph cells of the genital cord.

In the asteroid at sexual maturity, we find thus on the aboral surface of the body a hollow ring, more or less complicated, opening from one part into the axial sinus and emitting into each interradius two canals that surround each sexual organ of a genital sinus. From the axial gland leaves a complete cellular cord that runs around the aboral ring and goes to attach to the base of the gonads (figures in 28).

We now study a transverse section of the aboral ring (Asterias glacialis, pl. XXIX, fig. 68). The genital cord is attached to the wall of the sinus by a thick connective tissue blade. It is greatly lobed and subdivided in all directions by connecting tissue compartments. In these irregular cavities thus set off are found islands of coagulated liquid and especially very numerous nuclei identical to those of the axial gland. Moreover, generally there are, at the base of the partition, irregular masses of larger cells with nucleolated nuclei. These are the sexual cells (Urkeimzellen, Hamann). This mass of differentitated cells, identical to the mother cells of eggs or sperm, are found the entire length of the cord. From time to time, it detaches small branches that go into the lymph tissue of the cord.

The separation of the sexual cells and of the glandular part is scarecely encountered in Asterias. I have found no trace of it in Astropecten, Echinaster and Asterina. It thus is not necessary to exaggerate its importance.

OPHIUROIDS. - The development of the gonads begins very early in ophiuroids. They are already very clear in Ophiothrix fragilis with a disk of 2 millimeters diameter (in the adult D $=10$ $\mathrm{mm}$ ). The youngest stage that I have encountered is an Ophioglypha albida, whose $\mathrm{D}=3.5 \mathrm{~mm}$ (in the adult, $\mathrm{D}=12 \mathrm{~mm}$ ).

At its aboral end, the axial gland is formed of a very loose tissue containing much coagulum and few cells (pl. XXIX, fig. 65). A complete cord is produced in evident continuity with the gland, but whose cells have differentiated. In fact, some cells are trnsfored into sexual cells (oogonia, Urkeimzellen), whose large granular nucleus often has a nucleolus. These cells appear as soon as the cord leaves the axial gland. We find them its entire length, mixed with the usual small lymph nuclei. As in asteroids, the genital cord is surrounded by an enterocoelic cavity, a diverticulum of the axial sinus. The formation of the gonads is very simple. In places, the genital cord has swellings in which the sexual cells accumulate. These swellings push the sinus wall before them, so that the ovary or the testis is surrounded by a genital sinus. In the adult, exactly as in asteroids, the gonad remains always in communication with the cord that formed it, just as this one is continuous with the axial gland (pl. XXIX, fig. 67).

We now study the constitution of the abora ring in adults by serial sections (pl. XXIX, fig. $66,67)$. The cavity of the ring is very large and in one corner, as we know, is found the genital nerve center. Opposite the nerve center, we see the genital cord attached to the wall by a connective tissue blade. The sexual cells, easily recognized by their large granular nucleus, are assembled in a small mass very near the point of attachment of the cord. The rest is formed by a loose tissue, identical to that of the axial gland, enclosing a more or less large number of lymph cells with a small nucleus and a fine coagulum (fundamental gelatinous substance?). At the base of each gonad, the genital cord is attached by its wall (pl. XXIX, fig. 67). The mass of sexual cells is continuous 
with the sexual cells of the organ, future eggs or sperm. The rest of the cord is lost in the connective tissue wall.

The mass formed by the sexual cells, Genitalrohre of Hamann, is very clear in Ophiothrix fragilis, Ophioglypha lacertosa, Ophiocoma scolpendrina. They are very rarely free in the rest of the cord. In Ophioglypha albida, Amphiura squamata, Ophiactis virens, to the contrary, the sexual cells are mixed with small lymph cells (in the two latter species, the differentiation between the two kinds of cells is even negligible). Hamann (71) in Ophioglypha albida, sometimes figures a well-defined Genitalroohre (perhaps by error?). In other figures, he represents the two kinds of cells intimately mixed.

Functions of the genital cords and the axial gland. - As several authors have suspecgted, and as I have demonstrated in 1887, the axial gland of asteroids and ophiuroids is a lymph gland (or organ plastidogene). It is also this gland that produces the sexual sells that will give rise to the gonads.

In adults, the genital cord that connects the gonads to the axial gland nearly always contains a mass of differentiated cells (seuxal cells), forming a kind of continuous tube (Genitalrohre), enclosed by a cellular-fiibrous stroma indentical to that of the axial gland. The mass of sexual cells appears in the cord nearly in contact with the axial gland and ends at the gonads, continuous with their internal cells, mother cells of spermatogonia and oogonia. According to Hamann, the sexual cells are amoeboid and can move in the cord up to the gonads, where they develop naturally into sexual products. Although we cannot verify this directly, this theory appears to me completely acceptable, at least for the ophiuroids and Asterias glacialis. The sexual cells, derived from the cells of the axial gland, thus form a complex annular ensemble. It would be only on the appendages of this ring (gonads) that they reach maturity.

After spawning, the cells of new formation come probably in part from the genital cords. The rest is formed by the layers of renewal that remain in the ovaries and testes. It is naturally the latter that form all the new oogonia or spermatogonia in numerous asteroids (Asterina, Astropecten, etc.), whose genital cords do not contain errant sexual cells.

As for the cellular-fibrous stroma that forms the major part of the genital cord, I have aleady said that it is identical to the constitution of the axial gland. Like the latter, it contains in its lacunae an abundant coagulum (ophiuroids, Asterias glacialis), that has been interpreted as "Blutlacune" by Hamann. In most ophiuroids and asteroids, this stroma acts like a lymph gland.Amoebocytes form in its thicknesss and move into the cavities or surrounding tissues. If we want, we can consider the genital cord as formed of three intimately mixed parts: $1^{\circ}$ sexual cells forming all along the cord and moving toward the gonads; $2^{\circ}$ lymph cells resting on a fibrous reticulum, and developing into amoebocytes that move into the surrounding enterocoel; $3^{\circ}$ interstitial lacunae containing like the lacunae of the axial gand a liquid rich in proteinaceous material that moves by diffusion into the aboral ring and thus serve for the nutrition of the surrounding tissues and the gonads. I shall study later the lacunae in regard to the lacunar system.

History: - The complex system that unites in asteroids and ophiuroids the gonads and axial gland has been described exactly, nearly at the same time, by Hamann and myself (1886 to 1888). Several authors, notably Carl Vogt and Yung (182) and Koehler (88) have suspected its true importance. I have especially studied the relations of the cord with the axial gland and the production of the gonads $(28,29)$. Hamann has stressed especially the sexual cells and their movement (after having giving them wrongly an excretory function in 1885). For him, each cord is formed of a blood lacuna surrounding the mass of sexual cells. We have seen that the cords are 
quite certainly complete extensions of the axial gland, and that they do not always contain differentiated sexual cells.

ECHINOIDS. - In this class, development of the gonads has been studied only by Prouho, who has obtained results little different from those we have discussed above. It is advisable to consider this very closely.

In young Strongylocentrotus lividus of $3 \mathrm{~mm}$, the axial sinus nearly entirely filled by the axial gland, is limited by a connective tissue membrane containing like all the tissues mesodermal cells. It is in the thickness of this membrane (pl. XXX, fig. 72), on the side of the axial sinus turned toward the vertical axis of the urchin, i.e., below the hollow madreporite, that the first sexual cells develop, easily recognizable by their large granulated nucleolated nucleus. They probably derive from mesodermal cells of the wall, but as we see they have no direct immediate connection with the axial gland. Also they are not mixed with the lymph nuclei. This sexual bud, that forms a rounded projection on the wall of the axial sinus, goes around it in a fashion to pass onto the external surface (see the scheme of serial sections of Prouho, 151).

From this moment, development, so to say, is identical to that we have described in asteroids and ophiuroids. The genital cord, this time formed only of sexual cells, goes around the aboral surface. Between it and the test, the axial enterocoel extends in a way to form a hollow ring (pl XXX, fig. 69, 71, 72). If we make a section of this ring, we see the arrangement fixed in adult asteroids and ophiuroids. It is a vast cavity lined with an enterocoelic epithelium, limited on the side of the coelom by a thick partition. In the thickness of this partition is found the mass of sexual cells that will make a more or less pronounced projection (Hamann appears to have seen this stage in a young Sphorechinus granularis, 70). In the five interradii, the genital cord forms a large bud whose connective tissue wall appears split (pl. XXX, fig. 69, 72). It is not strictly speaking a genital sinus as in asteroids and ophiuroids. In order to finish with the sexual cells, we shall say immediately that they all move into the five buds, lining the wall with a single layer of large cells that are later oogonia and spermatogonia. In the partition of the aboral ring, we no longer find a trace of the genital cord. One, the original sexual bud produced in the wall of the axial sinus persists longer (pl. XXX, fig. 72) to atrophiy a little later. In a young urchin, immediately after the formation of the gonads, we find on the aboral surface a hollow ring communicating with the enterocoelic axial sinus (it remains thus in adult Echinocyamus pusillus, etc. pl. XXX, fig. 71). In the connective tissue wall of the gland is found a lacunar network (pl. XXX, fig. 69 and 72) that will become more and more clear as the animal ages. This network provides a lacework of lacunae that makes up the wall of the aboral ring, in which we can easily demonstrate in sections the presence of a characteristic coagulum (see the injections in Prouho, 151). The gonad emits a hollow extension that perforates the test at a right angle and is a gonoduct. Prouho has shown it at the very beginning (151, pl. 22, fig. 1). Fig. 72, pl. XXX, shows it at a more advanced stage, a little before it opens to the outside.

The aboral enterocoelic ring has a form a little different according to the urchins. In regular urchins (pl. XXX, fig. 72) it goes around the aboral surface, whose center is occupied by the rectum and periproctal cavity. In irregular urchins, it is relatively larger (pl. XXX, fig. 69) because of the absence of the rectum. In the internal circle are the stone canal and the axial sinus. With age, the ring develops some modifications. In most species, it constitutes a closed cavity, its communication with the axial sinus being obliterated. Finally in Dorocidaris papillata, as Prouho (151) has shown, the connective tissue wall that limits it is perforated with small holes that make free communication between the interior of the ring with the coelom. 
Morphological considerations. - We see that in urchins (at least in those that have been studied), the origin of the primitive bud is not absolutely the same as in asteroids and ophiuroids. Is there a fundamental difference between these two processes? Like Perrier, I do not think so. In fact, in both cases, the sexual cells come from the wall of the axial enterocoel, either directly (urchins) or indirectly at the expense of a formation derived from the latter (axial gland). The axial gland, as we have tried to demonstrate, can be considered ontogenetically as a considerable thickening of the wall of the axial sinus. It does not matter whether the sexual cells are formed in a still simple area or in another already differentiated into a gland.

For the rest of the development, we see that the urchins pass transitorily by the stage fixed in adult asteroids and ophiuroids: aboral ring communicating with the axial sinus (cavity of the axial gland); genital cord making a more or less projection into the ring. But soom the resemblance ceases: the genital cord disappears. In its place develops a system of lacunae lacking in asteroids and ophiuroids. The aboral ring itself develops some secondary modfications that we have enumerated above.

Another consequence follows the precocious atrophy of the genital cords. The layers of renewal are strongly localized in the gonads because there are no longer sexual cells migrating outside of them.

\section{SCHIZOCOELIC CAVITIES.}

ECHINOIDS. - In all echinoids we find five well developed schizocoelic radial sinuses, intercalated as usual beween the nerve band and the the water canals. At each tube foot, the sinus emits a small diverticulum that accompanies the nerve, but which is obliterated a little before it enters the test (pl. XXVII, fig. 38). The radial sinus ends in a cul de sac at the apical pole at the place where the nerve band enters into the terminal pores (pl. XXVII, fig. 42).

When we inject a radial sinus, we show that it is also closed on the side of the mouth and does not communicate with the four other sinuses. The colored liquid stops a little before reaching the nerve ring (see pl. XXVIII, fig. 53). Serial sections show this fact. In gnathostomes, regulars or clypeasteroids, we easily follow the sinus up to the place where it approaches the masticatory apparatus. The radial lacuna that separates the sinus from the nerve band approaches progressively the latter and ends up on its surface, the sinus being completely obliterated. The nerve ring is freely bathed by the peripharyngeal liquid.

In spatangoids (pl. XXVIII, fig. 54), the arrangement is nearly the same. The five radial sinuses end in a caecum, in contact with the membrane of the periesophgeal cavigty in which is found the nerve ring. Koehler (87) claims that the radial sinus communicates with this cavity. But injections and my sections have never shown this to me. In most specimens sectioned, the contents of the cavity and the sinus are very different.

As for the coelom, I have already spoken of the possible homology between the oral schizocoelic ring, which is lacking in urchins, and at least part of the periesophageal cavity of spatangoids.

History. - The very confusing history of the schizocolic sinus is very well treated by Perrier (147). In summary, whatever opinions have been expressed, there is absolute identity between the radial sinuses of urchins and those of other echinoderms. As in holothuroids and Antedon, they 
end individually in a caecum, instead of leading to an oral schizocoelic ring underlying the nervous system.

OPHIUROIDS AND ASTEROIDS. - In ophiuroids and asteroids, the schizocoelic system attains a high degree of development and nearly simulates a vascular system because of the branches it emits. It communicates, on one hand, with the axial enterocoel and consequently with the ensemble of the genital cavities, and, on the other hand, with the coelom by numerous holes, so that injecting by a radial sinus the liquid fills not only the schizocoelic ensemble (oral ring and sinus), but also the axial entercoel and its genital dependencies and then passes into the coelom.

In ophiuroids, the radial sinuses are well defined in all the species eamined (pl. XXVI, fig. $35,36)$. They accompany each ambulacral nerve up to the place where it reaches the tube foot, as in urchins. A little after each tube foot, they emit a small diverticiulum that goes to open on each side in the coelom of the arms, as we can easily demonstrate by injections and sections. The oral ring is no longer missing (XXV, fig. 28, 29). Although a thin partition separates it from the coelom (Ophiactis, Ophiocoma), I have never seen it communicate freely with the latter and still less, as Hamann said incorrectly, with the periesophageal space limited by a mesenteric partition. The axial sinus opens into the oral ring, but this communication is very insignificant because the sinus is nearly filled with the axial gland.

In asteroids, the schhizocoelic cavites are crossed by very complex septa in which the axial gland (genus Asteris) is sometimes extended. The radial septa (pl. XXV, fig. 21) constituted in the simplest case by a thin vertical connective tissue blade (Asterina gibbosa), going into the oral ring with an oblique septum (pl. XXV, fig. 22) on which the axial gland is implanted in an interradius. The oral ring is thus divided into two superposed stages, of which the most internal communicates mainly with the axial sinius. The septa do not obstruct the passage of injections except sometimes in large species (Asterias glacialis).

At each tube foot, the radial sinus emits a hollow diverticula that crosses the axis of the arm and goes to open into the coelom. The schizocoel and the enterocoel communicate thus with each other by numerous openings as injections have indisputably demonstrated. Likewise, the external and internal walls of the oral ring communicate with the coelom of the disk by five interradial openings, perfectly recognizable in dissections and sections.

Finallly, the entire path of the radial sinus sends to the tube feet wall vessels (two for each tube foot, produced at two opposite sites).

For a detailed description of the system and figues, I refer only to work on asteroids (28). This is well treated in the history of Perrier $(147, \mathrm{p} .7)$. There is no other schizocoel than that I just described. The cavities in the wall of the body described by Ludwig, Hamann, etc., are accidental cavities due to poor methods of preparation and have no relation to true schizocoelic sinuses.

Development. - In very young Asterias rubens, as shown by Hamann, there is no radial sinus. The nerve band is still very little differentiated and applied directly to the connective tissue layer of the arm. Little by little it separates from it, making the projecting roof that we note in the adult. The cavity is found thus formed in the midst of connective tissue, still obstructed in large part by the connective tissue tracts (see in 28, pl. 6, fig.1, the section of the arm of a young Echinaster sepositus with $\mathrm{R}=18 \mathrm{~mm}$ ). These tracts completely disappear except one that constitutes the septum.

In ophiuroids, the development of the schizocoel is somewhat similar. In Amphiura squamata, with the disk measuring $240 \mu$ (pl. XXV, fig. 26), the radial water canal is applied directly to the internal surface of the nerve ring. In another individual $560 \mu$ in diameter, it is a little separated from it and a poorly delimited cavity, half filled with mesodermal cells appears 
beween thse two organs. This cavity becomes regular little by little and soon has a considerable development. Sometimes in adults, it is crossed by small connective tissue septa (Simroth, Cuénot). The oral sinus has the same development.

The communicaton with the coelom on one hand and the axial sinus on the other hand is produced secondarily in the course of development.

\section{Lacunar-plastidogenic system.}

We have aleady seen that in holothuroids and crinoids, some parts of the lacunar sysgem are transformed into lymph glands: $1^{\circ}$ the end of the dorsal marginal lacuna in Cucumaria Planci; $2^{\circ}$ the entire oral plexus in Holothuria impatiens; $3^{\circ}$ some parts of the oral plexus (spongy organ) in crinoids. An analogous phenomenon is present in urchins, in which the distinction between true lacuna for circulation and glandular parts (plastidogen system of Perrier) is nearly impossible to make. In ophiuroids and some asteroids, the glandular dependencies of the axial gland containing a liquid rich in albuminoids and apparently playing a role comparable to that of true lacunae of urchins. We see that it is imposible to make a line of absolute separation between the lacunar part and the plastidogen part.

ECHINOIDS. - The lacunar system of urchins is easy to schematize: the absorbing intestine goes to an oral ring. This ring produces: $1^{\circ}$ five radial lacunae; $2^{\circ}$ a lacunar network for the axial gland, which itself produces a genital network.

In spatangoids (pl. XXVIII, fig. 54), I absolutely confirm the description of Prouho (11) in disagreeing with that of Hamann. The marginal lacuna of the intestine (end of the absorbing system) opens into an oral ring located below the water ring. In the sections, it is easy to show the lacunar ring, whose walls are very thick and that contains abundant coagulum. From the oral ring leave five large radial lacunae, located in the partition that separates the water canal from the radial schizocoel. At each tube foot, each radial lacuna produces a small branch that goes to the base of the tube foot where it crosses the test to the outside. From the oral ring also leaves the network of the axial gland that, at its lower end, produces a genital network located in the wall of the enterocoelic ring whose development we have studied (figures of the absorbing system in Kœhler, 87; figures of the complete system and schematics in Prouho, 151). We see that the lacunar system of spatangoids is perfecty clear and comprehensible in all its details. It is exclusively lacunar and shows no glandular differentiation.

In regular urchins and clypeasteroids, there is to note some important differences: The lacunar ring, generally locaed below the water ring, sometimes becomes glandular, either entirely (Dorocidaris papillata, Asthenosoma urens, Peonella orbicularis) or on only a part (spongy vesicles of most regulars and Echinodiscus biforis (pl. XXVIII, fig. 53). In these glandular parts, whose constitutioni is identical to that of the axial gland, the water ring has diverticula, facilitating diffusion and diapedesis.

The lacunar network of the axial gland, located in the peripheral zoneof this gland, has been very completely described byProuho (151) and I shall not return to it. At the aboral end, this network is continuous in the thickness of the membranes of the genital pentagon (Hamann, Prouho). The very irregularly arranged lacunate continue very far on the wall of each gonad (pl. XXX, fig. 69, 72). In the sections, this wall is split, nearly like that in synaptids. The circular cavity thus formed is crossed by numerous connective tissue tracts and contains the coagulum 
characteristic of the lacunar system. Besides Dorocidaris and the regulars cited by Prouho and Hamann, I have found these genital lacuna in Arbacia pustulosa and clypeasteroids.

I shall emphasize a little more on the radial lacunae that, up to here, have been described only by Prouho (151). We begin first with the normal regulars (Strongylocentrotus, Echinus, Spharchinus). Teuscher, Kœhler, and Prouho have reported along the pharynx the presence of five "pharyngeal vessels" that go to the oral ring. According to Prouho, these five pharyngeal vessels are continued into the radii by five hollow lacunae, as in spantangoids, in the thickness of the membrane that separates the water canal from the radial sinus. What is remarkable is that no one has been able to inject the pharyngeal and radial lacunae, although the oral ring can be injected easily. There is thus something else to investigate. To study in a sure way the path of these lacunae, I have cut into serial sections the entire masticatory apparatus of young urchins from the esophagus to the mouth (it is by the means of these transverse sections that the scheme, fig. 53, was made).

The first sections contain ithe water and lacunar rings. The latter is very recognizable with its contents of coagulate albumin. Then, the sections cut the pharyngeal lacuna. These appear as large rectangular cavities, separated from the oral ring by a continuous membrane. This arrangement that explains why injections do not pass from the ring into the lacunae is perfectly evident in the sections. For verification, we can see that the pharyngeal lacunae do not contain coagulum. Their cavity is always nearly empty.

The pharyngeal lacunae, accompanied by two muscular straps, continue along the length of the pharynx, gradually narrowing. When they reach the nerve ring, they are very small. They are applied then on the internal surface of the five radial bands as well as the two muscular cords (pl. XXVII, fig. 37). Some millimeters further, the radial schizocoelic sinus begins to appear. It gradually separates the lacuna from the nerve band. Finally, at the exit of the pharyngeal chamber, the lacuna is obviously in the partition that separates the radial sinus from the water canal (pl. XXVII, fig. 38). The radial lacuna thus constituted contains a fine coagulum with some included amoebocytes. At each tube foot, it emits a small branch that is lost in the tissues at the place where the tube foot enters into the test. I have seen the presence of the tube foot lacunae (described by Prouho in Echinus sphara, Strongylocentrotus lividus, Spharechinus granularis and clypeasteroids. Their existence is very probably general.

In Dorocidaris papillata, the arrangements are a little different (see the scheme of Prouho, 151, pl. XIX, fig. 1). The oral ring, the pharyngeal and radial lacunae, instead of being tubular cavities with an empty lumen, have taken a glandular character. They are nearly entirely filled with a connective tissue padding full of nucleated cells, completely like the tissue of the axial gland. The pharyngeal lacunae are constituted of glandular tracts, located in the thickess of the connective tissue layer of the pharynx and continuous with the tracts of the oral ring. Injections pass there only with difficulty and do not go far, the lacunae being in large part obstructed by the cells they contain. The radial lacunae strictly speaking following the pharyngeal lacunae, are likewise very different from those we have seen in the echinids. They are no longer hollow cavities in the partition that separates the water canal and the radial sinus, but a true glandular stroma with irregular edges, lying freely in the radial sinus. They emit some extensions that cross the cavity of the sinus and also of the tube foot branches (see the figures of Pouho). The pharyngeal and radial lacunae are formed of a connective tissue network, enclosing abundant coagulum with very numerous nuclei and cells in its meshes, completely like those of the axial gland. It is evident that the ring and the radial lacunae of Dorocidaris, while transporting absorbed protinaceous material from the intestine, plays the role of a lymph gland. 
In Peronella orbicularis, whose oral ring is glandular like that of Dorocidaris, the radial lacunae are hollow cavities like in echinids. It barely extends some glandular tracts into the pharyngeal portion.

OPHIUROIDS. - We know that the axial sinus is nearly entirely filled by the axial gland. This, in reaching the oral side, is reduced to a thin peduncle that goes to the internal or lower border of the nerve ring. From this peduncle leaves a ring that goes around the mouth that we shall call the oral lacunar ring. In Ophioglypha albida (Hamann) and lacertosa (Koehler), and Ophiothrix fragilis, the oral ring is located on the lower border of the nerve ring gand enclosed with it in the oral sinus. In Ophiocoma scolopendrina (pl. XXV, fig. 28), the lacunar ring is located outside the oral sinus in one of the periesophageal cavities.

In each radius, the lacunar ring emits a radial lacuna that is located under the nerve band ( $\mathrm{pl}$. XXVI, fig. 35). At each tube foot, the radial lacuna emits a transverse lacuna (pl. XXVI, fig. 36) that accompanies the ambulacral and peripheral nerves is lost at the base of the tube foot (Ophiothrix, Ophioglypha, Ophiocoma, Ophiactis, Amphiura, Astrophyton).

From the aboral side, we know that the axial gland produces the genital cords that, after a very complicated trajectory, goes to the gonads (pl. XXIX, fig. 67).

What is the histology and importance of this ensemble of the lacunar cords? We know that the axial gland takes up a liquid very rich in albuminoid material. Also we find abundant coagulums in the sections. The oral ring and the radial lacunae are extensions of the axial gland having kept in part its glandular structure but always filled with the same nutritious liquid. In Ophiocoma scolopendrina (pl. XXV, fig. 28), the lumen of the oral lacunar ring is crossed by small connective tissue septa that are generally missing in the other species. The radial and tube feet lacuna always have the same constitution. They enclose an abundant very characteristic albumen and some cells are completely like the cells of the axial gland. It is not doubtful that the lacunae can function as lymph glands. This is not surprising because they are direct extensions of the axial gland.

In most species, the nerve bands have a structural detail related to the radial lacunae. Toward the middle of the band (pl. XXVI, fig. 36), we often see small irregular cords, staining brightly with carmine, that leave the peripheral nuclei and go to the radial lacuna. Hamann was the first to report them in Ophioglypha albida. I have found them very clearly in Ophiothrix fragilis and Ophiocoma scolopendrina. These cords are certainly not of nervous nature. I think that they are cellular filaments transformed into a permeable tissue that permits the contents of the lacuna to penetrate by imbibition into the thickness of the nerve tissue. That is near the opinion of Hamann.

In small species, Ophiactis virens, Amphiura squamata and even Ophioglypha albida, the genital cords contained in the aboral ring are entirely cellular. But in large species, notably Ophiogthrix fragilis, Ophiocoa scolopendrina, Ophioglypha laacertosa, etc., the sesual cells are separated to form a separate cord. The rest of the cord is formed of a connective tissue-cellular tissue enclosing, like the radial lacuna, a fine albuminous coagulum (pl. XXIX, fig. 66).

In summary, if we envisage the relations of the radial lacunae and the oral ring on one hand, of the genital cords on the other hand, with the axial gland as well as their glandular constitution, it appears natural to consider all as a complicated plastidogen system (Koehler, Perrier). In contrast, fwe give more importance to their contents, that often recall in a complete way the contents of the lacunae of urchins, crinoids and holothuroids, it will be no less logical, in spite of the absence of an absorbing system, to make them a "Blutlakunesystem" (Lange, Ludwig, Hamann). The truth is that this system combines the two functions. Throughout its path, it produces 
amoebocytes (and also sexual cells). It functions likewise to carry in some parts of the organism a nourishing liquid produced in the axial gland.

History. - Simroth has not recognized the lacunar system of Ophiactis virens (1876). It is true that in this species of small size, it is not easy to document. Teuscher (1876) has reconized the radial lacunae and oral ring, but he considers them to be nerve cords, an error that can be easily explained because the fine coagulum of the lacunae greatly resembles transverse sections of nerve fibers. Lange (1876) found in various ophiuroids the radial lacune (radiale Bauchgefäss). Ludwig (1878) describes completely the ensemble of the system, aboral ring, oral ring and radial branches but in an extremely schematic way. He considers all as a vascular system, wih the axial gland as a heart. Apostolidès has made only errors refuted mostly by Koehler (1877). This last author has described with precision the "vascular system". Perhaps he did not see the lacunae clearly. He attributes a glandular importance to the oral ring and to the radial lacunae. Perrier (1888) accepts Koehler's ideas from this point of view and gives the name plastidogen tubes to the radial lacunae. In my work on ophiuroids (1888), I am very little concerned with the lacunar system. I thought wrongly that the radial lacunae were constituted of complete cords without importance, kinds of connective tissue tracts. Hamann has studied with his usual precision the "Blutlakunensystem" of ophiuroids (1889). He has perfectly described from the histological point of view the radial lacunae and the oral ring. He considers them, too exclusively in my opinion, as true lacunae. For the aboral ring, Hamann describes the sexual cord (Genitalröhre), as surrounded by a "Blutlakune". We have seen that this lacuna is nothing other than a glandular stroma, continuous with the axial gland that, it is true, encloses in several species a nourishing liquid like the radial lacunae. Finally, I assured myself that the lacuna that according to Hamann would go to the digestive tube did not really exist. He has been without doubt deceived by an oblique section of the aboral ring where it extends over the surface of the digestive tube.

ASTEROIDS. - In only some species of asteroids are there rudimens of the lacunar system in the thickness of various extensions of the axial gland, as in the ophiuroids. In the great majority of species, the septa that go through the schizocoelic sinus are complete connective tissue blades, sometimes even calcified (Gymnasteria carinifera), not containing a cavity. The axial gland is implanted on the septum of the oral schizocoelic ring. There is thus neither radial lacunae nor an oral lacnar ring. The genital cords derived from the axial gland are likewise complete cellular cords in which we find no characteristic coagulum. There is thus no trace of the lacunar system in most asteroids, notably Asterina gibbosa, Echinaster sepositus, Astropecten, Luidia, etc. I insist on this point that is unknown in all classical books or recent works relative to asteroids.

But in the genus Asterias appears an interesting differentiation. The axial gland, instead of simply implanting on the septum of the oral ring, is continuous all around the ring and from there into the five radial septa. When the axial gland reaches the mouth, its tissue is no longer very compact. It is hollow with more or less irregular cavities, containing a fine albuminous coagulum. The oral plastidogen lacunae (pl. XXV, fig. 22), very irregular in form, is divided by connective tissue tracts into small secondary cavities containing, like the axial gland, numerous cells and an albuminous coagulum. Likewise for the radial plastidogen lacunae (pl. XXV, fig 21), hollowed into the thickness of the radial septum. They do not send branches to the tube feet. The genital cords (pl. XXIX, fig. 68) show likewise irregular cavities filled with the same coagulum.

This entire ensemble derived from the axial gland, aboveo and below, has clearly over its entire course the importance of the lymph gland (28). But as for ophiuroids, we are forced to admit that it intervenes in some way in the transport of the nourishing liqid that seems to have its center of formation in the axial gland. It is in this sense that we can consider the plastidogen organs as a 
rudiment of the lacunar systm. As for the two vessels going to the stomach sac (Giedemann, Hoffmann, Ludwig, Hamann), I have shown in 1887 that these were glandular extensions coming from the axial gland and function to furnish amoebocytes to the coelomic liquid.

The oral plastidogen ring iand the radial lacunae appear constant in the genus Asterias. They are very well developed in Asterias rubens, glacialis and tenuispina. Perrier reported them in Aserias spirabilis. Their development is very late. At a young age, the oral and radial septa are complete connective tissue blades (fixed stage in most other asteroids) and the axial gland does not emit ramifications. This is why Hamann has not recognized the system in young Asterias rubens $(2 \mathrm{~mm})$ that he studied. According to Perrier, it is the same for very young Asterias spirabilis $^{40}$.

MORPHOLOGY AND PHYSIOLOGY OF THE LACUNAR SYSTEM. - All authors since Ludwig agree in homologizing the lacunar system of the various classes in the same ways as the water vascular system, which is to say that they were inherited from one class to the other. This is not our opinion. In spite of the incontestable resemblances, we consider these various systems as being developed independently in each class. They have among them only a purely physiological homology. It is easy to explain why they seem built on the same plan. It is that they always respond to the same needs. I.e., to carry nutritious liquids (coming from the digestive tube) to the lymph glands, gonads, tube feet and nerve cords. They are simple resemblances from convergence.

$1^{\circ}$ Lacunar system with absorbing intestines. - We first examine the types in which the lacunar system has principally absorbing lacunae of the digestive tube.

In synaptids, it has its greatest state of simplicity. The collecting lacuna goes directly to the gonads. A small branch is detached and is lost in the periesophaeal tracs (pl. XXVIII, fig. 52).

In holothuroids, the two maginal lacunae go to a diffuse oral ring, from which leave five radial lacunae that give branches to all the tube feet. The genital lacunae go either to the oral ring or to the dorsal lmarginal lacuna (pl. XXX, fig. 76). One part of the lacunae (the complete ring in Holothuria impatiens, fig. 75, the oral portion of the dorsal marginal lacuna in Cucumaria Planci, fig. 74) is transformed into a lymph gland in the meshes of which flows the nutritious liquid.

In crinoids, the intestinal lacunae end at an equally diffuse oral ring (labial plexus), which is transformed in places into a lymph gland (spongy organ). A lacunar plexus surrounds the genital stolon (axial organ) whose functions are very problematic.

In urchins, the intestinal lacunae go to a well defined oral ring, form whence leave five radial lacunae identical to those of holothuroids and a lacunar network that goes to the axial gland, an organ that appears to us for the first time. At its aboral end, the network of the axial gland extends into a plexus ring that nourishes the gonads. Often the lacunar system transforms into a lymph gland over a more or less large part of its course, this tissue being continuous or not with the axial gland. This is the case of the oral ring and radial lacunae of Dorocidaris papilla, the oral ring of Peronella orbicularis, the spongy vesicles of echinids and Echinodiscus biforis.

$\delta$. How can this lacunar system function? This seems very understandable to me. The absorbing lacunae are filled with digestive products, liquids very rich in albuminoids ${ }^{41}$, Then by a vis a tergo impossible to show directly, but we can completely accept that the nutritious liquid

\footnotetext{
40 This that Ludwig describes (110) in the embryos of Asterias gibbosa as oral lacunar ring is nothing but the schizocoelic ring (Hamann).

${ }^{41}$ This fact, between parentheses, is a very strong confirmation of the theories of Neumeister, Nadina Popoff and Julia Brin. For these authors, the transformation of peptones from ingested quaternary material and the reconstitution of the peptone in assimilable albumin, is produced in the intestinal epithelium. In this hypothesis, one easily understands why the absorbing lacunae on the digestive wall has from their beginning a liquid very rich in albumin.
} 
goes little by little towards the oral ring, aided more or less by the contraction ofo the lacunae (shown well in holothuroids) and by the call from the ends following continuous absorption. At the oral ring, there appears to be considerable diffusion of the nutritious liquid into the surrounding parts, enriching the liquid of the water vascular system and the coelomic contents. Iin fact, the oral ring is always more of less diffuse and provides a large surface of exchange, as in holothuroids and crinoids, or is intimately mixed with the water ring as in gnathostomous urchins. However, the radial lacunae still leave from the oral ring very rich in proteinaceous material that go to the end of the radii, emitting small branches that are lost in the tissue of the tube feet. Over their course, without doubt, diffusion occurs between their contents and that of the schizocoelic sinus in a way to assure the nutrition of the nerve cords. Moreover, in urchins, the axial gland and the gonads are richly vascularized (let me use this catchrese in speaking of the lacunae) at the expense of the oral ring.

$2^{\circ}$ Lacunar system lacking absorbing intestines - In urchins and some higher asteroids, the conditions are very different. There is no absorbing system at all nor anything equivalent (although the fact is accepted without question, I have verified it by sections in a very rigorous way). However, the cavities of the axial gland and its branches that leave it (oral lacunar ring, radial lacunae, genital cords) contain a liquid very rich in proteinaceous material, completely identical to that of the true lacunar system of the preceding echinoderms and even in ophuroids. Although the whole ensemble has the glandular character, it does not stop having (at least for the radial and tube feet lacunae) a superficial resemblance to the true lacunar system. What is the source of this nutricious liquid that does not come directly from the intestine? I thought in 1887 (28), and I still think, that the amoebocytes that formed the nutritious albumenoids from the products that passed by the intestine into the liquid cavity. In this hypothesis that Cattaneo has accepted and that disagrees with that of Neumeister, Brink and Popoff, we easily explain that the axial gland and its branches, that are the sites of formation of amoebocytes, contains a liquid as rich in albuminoids as the aborbing lacunae of synaptids, holothuroids, crinoids and urchins. Thus is formed a kind of rudimentary lacunar system that plays nearly the same role as the lacunar system with absorbants of the preceding echinoderms.

Homologies of appended glands. - Are the glandular organs in the different classes that are appended to the lacunar system, axial gland, genital stolon, spongy organs really homologs of each other as most authors think? This is a good question. I am going to evaluate and resolve it based on the criterion of organogenesis.

A. In urchins, ophiuroids and asteroids, the axial gland is completely homologous and we have never doubted this. There are in the three classes the same connections to the stone canal. A more important fact is that they certainly dvelop on the internal wall of the axial enterocoel. The gland, or by default, the enteroceolic wall from which it derives, emits extensions where sexual cells multiply and emigrate to form the gonads. Finally, it always has the same plstidogenic role. The homology is thus perfect.

B. We pass to the crinoids. The glandular wall that crosses vertically the disk (plexiform gland, axial orogan, dorsal organ, genital stolon, etc.) is considered nearly unanimously ( $\mathrm{H}$. Carpenter, Perrier, etc.) as homologous to the axial gland of the preceding echinoderms. And this homology has appeared to receive its later confirmation when I showed in asteroid the axial gland forms the genital cords as Perrier had describd previously for the genital stolon of crinoids. However I am convinced that there is not really a homology beween these two formations, that the genital stolon is developed independently in crinoids and that there is nothing in them that one can homologize to the axial gland. It is not difficult to demonstrate this. 
$1^{\circ}$ The best argument is taken from organogenesis. In urchins, ophiuroids and asteroids, the axial gland develops in the interior of the axial enterocoel, in connection with the early stone canal. Now in crinoids, as Ludwig and especially Bury have shown, the early stone canal is related to an identical enterocoelic vesicle. But we know very well that this vesicle, at first very large, is then included in the wall of the body (parietal sac of Perrier) and is nearly completely obliterated. The genital stolon or axial organ, on the other hand, develops without any connection with the enterocoelic vesicle. It forms in the thickness of a longitudinal mesentery in contact with the digestive sac, making a curve that leaves from the center of the calyx, goes into interradius BC and ends opposite radius $\mathrm{C}$. The axial organ thus is not located in the same interradius as the axial enterocoel (int. CD) of urchins, ophiuroids and asteroids. Consequently, because the axial enterocoel that produces the axial gland in these three classes, atrophies in crinoids and that the axial organ of these animals produces on a quite different enterocoelic wall, it follows that it cannot have any homology between thee two orders of organs.

$2^{\circ}$ Many other differences in detail support this conclusion. The axial organ does not have the constitution typical of the axial gland being formed of twisted tubes lined with a special epithelium. It is nearly certain that this is not a lymph gland.

It is true that the gonads form on extensions from the axial organ. But these extensions leave from the oral end of the gland, while the genital cords always detach from the aboral end of the axial gland (it is this comparison that led Perrier to return to the comatulid to compare to asteroids and urchins). There is thus only a quite superficial resemblance

C. In holothuroids, Hérouard (73) considers as a rudiment of the axial gland (Cucumaria Planci) a glandular differentiation located at the level of the stone canal and that we have seen formed by the end of the dorsal marginal lacuna (pl. XXX, fig 74). Is this point of view acceptable? For us, no more than in crinoids, there is no part corresponding exactly to the axial gland. We note, first of all, that this glandular differentiation is completely inconstant, that it is lacking in neighboring species or can occur in a different place (Holothuria impatiens). Bury has shown that the axial enterocoel, which exists at the beginning of developent as in the other echinoderms, is completely obliterated. It thus cannot form in its interior an organ comparable to the axial gland. Finally, it is proven that these plastidogen masses have no role in the formation of the gonads, which separates them completely from the axial gland.

$\S$ In summary, In synapatids, holothuroids and crinoids, the axial enterocoel, originaly interposed between the stone canal and its external pore, is more of less completely obliterated in the course of development. To the contrary, in urchins, ophiuroids and asteroids, it persists and has a great development. In its interior, a lymph gland develops, the axial gland, which is the center of formation of sexual cells. In the first three groups, it is developed into the coelom or lacunary system, of analogous organs that nearly physiologically correspond to this gland (either as organs forming amoebocytes or as the center of formation of sexual cells) but that cannot have any acutal homology with it.

Considerations on the origin of gonads. - In echinoderms, as in other coelomates, the gonads develop on the wall of the enterocoel, at the expense of the stroma derived from the enterocoelic covering. In synaptids and holothuroids, the first sexual mass is in the mesenterial partition called dorsal. In crinoids, the gonads derive from a preexisting gland, the axial organ or genital stolon whose function is still not known. In urchins, the primordial bud forms in the thickness of the axial sinus, close by the axial gland. Finally, in ophiuroids and asteroids, it is this latter gland that produces the genital cordons. In other words, it is a lymph gland that is the center of formation of sexual cells. We find a similar relation in some trochozoids, Aphrodite aculeata 
and Hermione hystrix among annelids, Bonellia among the gyphryriens and finally the bryozoans. In all these types, the sexual organs are formed either in the stroma of an enterocoelic lymph gland or in its extension (32).

What is special in echinoderms, as Hamann pointed out, is the formation in adults of sexual cells outside the gonads and the progressive movement of these cells to its interior. In the genital cords of neocrinoids, some ophiroids and Asterias glacialis we find masses of cells completely like early sexual cells (Urkeimzellen) that end up in the terminal gonads, where they probably migrate there to form either eggs or sperm. In hydroids, there is a similar migration of sexual cells derived from the ectoderm that reach maturity in the sporosacr of medusoid buds.

\section{GONADS}

Development of eggs. - At the beginning, the ovaries are formed of a mass of completely similar cells. Only some develop into eggs. The others constitute yolk cells, often amoeboid, making various albumenoids destined to pass into the protoplasm of the eggs. Without going into detail, I am going to summarize the relation of the eggs and the yolk cells in the different groups.

In asteroids, yolk accumulates in the cells of the connective tissue tracts in the ovary. It goes into the eggs by a kind of contact digestion. The yolk cells are applied closely to the surface of the latter (figures in 28). As the egg increases in age, we see very clearly that yolk is accumulated in the protoplasma and makes it less transparent. There is a yolk in some species (probably all those whose development from the larva is very condensed, Asterina gibbosa, Echinaster sepositus). Jatta (80) has described well the eggs of Asterias glacialis. He says he found in the vitellus a yolk nuceus (Dotterker) analogous to those that we have described in the araneids and numerous animals. Jatta is probably wrong, because I have not seen the yolk nucleus, no more than Fol and Hertwig.

In ophiuroids, the egg is continous with the yolk cells by the intermediary of a protoplasmic pedicle (figures in 29). It is directly by this way that the yolk granules enter the egg. When it is mature, the pedicle atrophies and the egg becomes regularly spherical.

In urchins, as we have known for a long time (Ludwig, etc.) the ovary is covered in the interior by a single layer of germinal cells (figures in Koehler, 87). A large number of them become eggs. The others reach a large size and ae filled with large proteinaceous granules. These yolk cells are intercalated between the eggs or spread out on their surface. We recognize this easily by the use of the appropriate stain that the yolk granules are little by little digested by the egg as they increase in size. When the eggs are mature, the yolk membrane being formed, they detach from the wall to fall into the ovarian cavity. The vesicle and the germinal patch then completely disappear. We find in their place only a small rounded mass of chromatin that is difficult to demonstrate. This peculiarity appears general for uchins. It was first reported by Hertwig in Strongylocentrotus lividus. It has been found by Koehler and myself in all studied species of regular urhins, clypeasteroids and spatangoids.

In Antedon, development of the eggs recalls what we have seen in asteroids and ophiuroids (pl. XXX, fig. 78). The very numerous eggs extend a long pedicle that goes into the yolk cells. We see very clearly (osmic acid) the yellowish granules that go into the pedicle and accumulate in the protoplasm of the egg. It is probable that the migration of the granules is due to protoplasmic currents. Other eggs do not have a pedicle. The contact with the yolk cells is then immediate. Often 
the protoplasm of the egg appears fused with them. In staining with a triple mixture (see Technique), the eggs take according to their age very characteristic colors. The cell body of young eggs is moe or less greenish and become compleely orange in mature eggs according to the accumulation of proteinaceous granules that fix orange 3. The mature eggs of Antedon Eschrichii no longer have the germinal vesicle. All the chromatin is located in a small female pronucleus, as in urchins.

I have not studied the development of eggs of holothuroids. It can be found in the figures of Hamann (67).

Egg. - When the egg is expelled from the animal, it is simply coveed with a primary ovular membrane always formed by the secretion of protoplasm from the egg. There is never a defined follicle around the free egg. The cells that are sometimes reported that are nothing other than yolk cells spread on the surface of the egg in process of absorption.

The egg membrane is sometimes a clear membrane (oolemma pelucida), more or less thick of gelatinous consistency (Synapta, Antedon, ophiuroids, asteroids), and sometimes a radiating zone with fine radial canals (holothuroids, Asterias glacialis) and likewise of mucilaginous consistency. The membrane of the egg forms only very late when it is ready to reach maturity.

The egg of echinoderms has no very interesting particularities. In Synapta digitate, according to Leydig, the germinal spot is still attached to the nuclear membrane. In Synapta inharens (pl. $\mathrm{XXX}$, fig. 77), the early germinal spot produces a quantity of small secondary nucleoli that go into the clear protoplasm of the germinal vesicle. Nearly always the spot has a mamelated aspect because of the formation of these nucleoli. According to Jensen (81), in Cucumaria frondosa Forbes, each nucleus of the mature egg has 15 to 30 germinal spots, always located under the nuclear membrane.

Development of the Spermatogonia. - Because of the small size of the seminal elements, their study is very difficult in echinoderms. I have pushed analysis of development as far as I have been able in asteroids and ophiuroids. My concusions do not differ greatly from those of O. Jensen in holothuroids, but there still remain many obscurities to dispel.

The male ovules or spermatogonia are very large cells in general (especially ophiuroids and holothuroids) with large granular nuclei, forming several layers at the internal surface of the testis. The most internal, by repeated divison, produce masses of nuclei a little smaller, the spermatocytes, that form a group more or less well defined, the spermatogen. In holothuroids, according to Jensen, the spermtocytes are not arranged regularly, one behind the other and we can say only that there are defined spermatogems that we can attribute to segmentation of a single spermatogonium. In asteroids and perhaps ophiuroids, the spermatogens are clearer and isolated (figures in 28 and 29). As we move away from the layer of spermatogonia, the spermatocytes become smaller and smaller. The smallest are reduced to a simple globule of chromatin.

The transformation of spermatocytes in the sperm occurs from inside out. After their release, there remain on the internal wall several seats of spermatogonia that will serve to generate testicular cells.

All the sperm of echinoderms have the classic form. Before maturity, the head has a small clear appendage or a refringent globule (nucleolus, stalk of Jensen, caudal segment) that disappears or appears to be expelled when the free sperm become definitively mature. Because of the difficulty of these cytological studies, I shall be content to call attention to this particularity, that I shall not try to attach to the analogous results obtained by various histologies.

Gonopores. - The gonopores, little apparent in the periods of sexual maturity, are to the contrary very clear at the moment of spawning. 
In holothuroids, the male or female gonopore is found, as we know, at a variable location in interradius CD. In some species (see the list in Ludwig, 114, p. 185) and especially in males (Thyone aurantiaca and fusus, Cucumaria elongata, etc.), the gonopore is located at the top of a, very projecting papilla in the form of a penis that evidently assures the dissemination of the gametes. In this regard, Hérouard (73) remarks that during several years in a row, Thyone aurantiaca have been taken at Banyuls in the first days of March. He asked himself if this was a coincidence or if the fact had a relation to the biology of the animal, notably with reproduction. I believe it is a coincidence because in 1889, we collected at Banyuls a Thyone near 17 April, another near 27 of the same month and a third toward 25 May.

Rarely the gonopores are multiple for a single gonad (Elpidida and Deimatida).

In echinoids, gonopores in variable number are always on the aboral surface, most often in relation to basal (genital of authors) plates. This relation is only secondary. It is very probable that in the ancestors of urchins the gonopores were located near the plates but not enclosed in them. In numerous urchins, this characteristic remains intact. In Laganum putanami, Peronella Peronii Encope, Mellita, etc., the pores are between the basal plates and the last two interambulacrals. In Clypaster rosaceus, they are entirely in the interradial sutures, separated from the apex by the two or three last pairs of interambulacral plates (Lovén). In Asthenosoma urens (according to Sarasin), Goniocidaris canaliculata, (according to Studer), and Porocidaris purpurta (according to Aassiz), the gonopores are also in the interradial areas. In a large number of Goniopygus (Cotteau), Acropeltis and Hemipygus, they are in contact with the basal plates. In other species of the same genus they ae included in them, but completely on the border towrd the oral pole. In a specimen of Colobocentrotus atratus Brandt (Senegal) that I have had in my hands, the pores are notches on the oral border of the basals, but without going into their interior (Agassiz has not reported this character in his Revision, 2). This stage appears to be the primordial form of the openings. I have often found it in young specimens of Strongylocentrotus lividus. We thus see that the gonopores have no strong morphological relation with the basals and originally they opened into the peristome as in the other echinoderms.

The gonoduct develops from the inside out by absorbing little by little before it the calcite of the underlying intgument. Sometimes from anomaly, the gonoduct is double or even triple, and on each basal ae two or three openings. Ch. Janet and I have reported in our note (34) all described cases by authors and some new forms ${ }^{42}$. This anomaly is almost constant in Salenia folium-querci Desor (of the Neocomien) ${ }^{43}$ and some palechinids (Melonites, Palechiniius). In Salenia, there are two pores on each basal. There are three in Palechinus elegans and spharixua (Baily and de Koninck); two, three, four or five in Melonites multipora (Römer, Meek and Worthen). It is interesting to note in the oldest known urchins the presence of a character as secondary as this one. This example shows us, among a thousand others, how the information from the order of paleontological appearance contradicts morphological deductions.

In some urchins, there is a genital papilla as in holothuroids. It occurs in male and female Echinocardium (Hamann), Echinus acutus and Ddorocidaris papillata (Prouho, Echinocyamus pusillus and Echinodiscus biforis (I have only males of the last two species). In the clypasteasteroids studied, the papillae are lined inside with a tall ciliated epithelium (Hamann figures the same thing in Echinocardium). But although there are free sperm in its canal, the papilla

\footnotetext{
42 I found an example in Echinus miliaris O. F. Müller from Portel (Pas de Calais). The basal AE has two very separated gonopores, with each going to an gonoduct, although the ovary is single.

${ }^{43}$ LAMBERT. Note sur un cas de monstrosité de l'apex chez l'Echinocorys vulgaris. Bulletin Soc. des Sciences del'Yonnoe, 1er semester 1890 (see p. 34).
} 
(pl. XXX, fig. 69) is clearly closed at the end. It is probable the opening is formed by dehiscence, perhaps beause of the pressure exerted by mature sperm. The thick wall is simply connective tissue without musle fibers. There is no reason to regard these papilla as penises. Instead they are organs of disseminaton of sperm and eggs.

In nearly all ophiuroids, the gonads end in the wall of the bursae. In the periods of sexual maturity, there are really no gonopores, as we show in fig. 67, pl. XXIX. It is only at the moment of spawning that these virtual openings dilate to allow the eggs and sperm to pass.

In Ophiactis virens, as I have said above, there are no bursae. The gonads (two per interradius) open directly outside on the interradius sides. In the adult specimen figure pl. XXIX, fig. 59, the small gonoduct and the opening are very clear and sperm even in the process going to the outside.

In asteroids, I have nothing to add to that we know of the gonopores (see 38). They are located on the aboral surface of the ams and the disk, always in the intervals of the perisomatic skeleton. The openings ae sometimes multiple for a single gonad (Asterias, Solaster ${ }^{44}$. In Asterias gibbosa (Ludwig, 102), the pores are on the oral suface, particularly related to the special spawning of this species.

Hermaphroditism. - In echinoderms, we know with certainty some hermaphrodites. All the studied species of the genus Synapta and Anapta (de Quatrefages, Leydig, Joh. Müller, Selenka and Semper), some species of Chiridota (notably Ch. Rotifera Pourt.), Amphiura squamata (Metschnikoff) and Asterina gibbosa (Cuénot). The other hermaphrodites reported by Semper (Haplodactyla molpadioides, Caudina arenata) are considered very doubtful (see in Ludwig, 114, p. 180, an excellent history of this question ${ }^{45}$. Hermaphroditism in echinoderms thus appears to be exceptional. It is only in synaptids that it becomes a little more general (without being a character of the class). It is advisable to examine with care if the hermaphroditism is real, i.e., if there is selffertilization or if it is simply anatomical.

Synapta inihorens. - The genietal caeca contain both eggs and sperm. When we make sections of the indifferent stage, we see that the sexual cells are divided into two layers. The more internal has eggs, the more external has spermatogonia. The eggs mature first and are expelled outside. After spawning, we can no longer find a single one in the gonad. The spermatogonia develop in their turn and produce a large number of sperm that are also expelled into the ambient water. The remaining cells will form the future eggs and spermatogonia. We see thus that selffertilization is absolutely impossible. The eggs are mature and spawned although there is not a single sperm formed. The sperm mature in their turn when there is no longer an egg in the caecum. Physiologically speaking, the synaptids are first females, then males and thus one after the other for each period of sexual maturity.

What is very singular is that all synaptids collected the same day and in the same locality are in exactly the same stage, whatever their respective age. In the first lot I examined, the gonads were all in the indifferent stage, i.e., containing immature eggs and undeveloped spermatogonia. In the second and third lots, collected at Roscoff the $1^{\text {st }}$ of July and the $1^{\text {st }}$ of August 1890, the synaptids were esclusively males and contained large quantity of mature spermatogonia. In a fourth lot, collected at Roscoff on December 1890 (pl. XXX, fig. 77, the gonads of all specimens

\footnotetext{
${ }^{44}$ In my work of 1887, I considered the gonopores of Solaster papposs to be single. I have just recognized in a large specimen that each of them is crossed by small, more or less numerous calcareous tracts so that there are several openings for each gonad. (Müller and Troschel.)

${ }^{45}$ Hermaphroditism could be presented as an anomaly in a normally dioecious species. I have reported an example in Asterias glacialis (28).
} 
examined were ovaries and contained only nearly mature eggs or in the process of development, as well as the spermatogonial masses. But I have not seen a single living sperm. After these results, that coincide with the results of de Quatrefages, the eggs would be spawned first and remain for some time outside before being fertilized by the sperm that are expelled much later. If I have not been mistaken by a coincidence, which would surprise me, there is a curious biological fact to confirm.

Amphiura squamata. - Hermaphroditism of Amphiura is completely different from that of synaptids. As first reported by Metchnikoff, the same animal contains distinct ovaries and testes (126). They are small rounded glands that extend into the bursae, very near the exterior opening. The testes are located at the periphery of the disk and generally project into the interior of the arms. The ovaries, to the contrary, are located in the interradius, very near the peristome. Consequently, the animal in its natural position, the testes ae higher than the ovaries. Their number is variable. As a general rule, there is one ovary and testes for each bursa, but nearly all the specimens have some irregularities (pl. XXX, fig. 79). The overies contain a small number of eggs (Schultze). There are generally only two or three mature ones at at the same time in each gonad. In the testes, the spermatogonia ae likewise few. We know that the eggs are expelled outside but are spawned into the bursa where they remain until their complete development into young ophiuroids.

Individuals whose disk measures $1.5 \mathrm{~mm}$, the bursae are very small and the gonads are in the process of development. When the disk attains $2 \mathrm{~mm}$, the individuals are reproductively mature but there are no embryos in the bursae. It is only when a diameter of $2 \mathrm{~mm}$ is surpassed that the bursae begin to bcome incubators and take a very great development. All the specimens of this size that I have examined (Naples, April-May) have 2 or 3 embryos per bursa, but scarcely more. The ovaries and the testes are not mature at the same time, although there does not appear to be a very regular succession as in synaptids. In several specimens examined, whose bursae were filled with young embryos (which shows that the season of the next spawning must be very far), most ovaries have nearly mature eggs. The testes contain well developed sperm, ready to be expelled. It is quite evident that in this case, there could be no self -fertilization and that the sperm of these individuals would surely fertilize eggs of other Amphiura. In summary, in Amphiura squamata, there is no physiological impossibility of self-fertilization as in Synapta inhaerens, but this should be extremely rare, the sperm being expelled at the moment when the bursae contain embryos and when the eggs are not mature. To resolve the question with absolute certainty, it would be necessary to raise in captivity isolated Amphiura and see if they can really self -fertilize themselves.

Asterina gibbosa. - I have previously studied hermaphroditism of Asterina gibbosa (28). I shall thus only summarize the question. The eggs and the sperm dvelop in the same gonad. In young individuals, whose $\mathrm{R}=12 \mathrm{~mm}$, the genital caeca contain rudimentary eggs and completely mature sperm. They are thus physiologically males. To the contrary, the adults whose $\mathrm{R}=26 \mathrm{~mm}$, there are no longer sperematogonia. To the contrary, the eggs reach complete maturity. The adults are thus exclusively females. In summary, young individuals function as males, the adults as females. Self -fertilization is physiologically impossible.

General considerations. - It is interesting to note that in two hermaphroditic species, Amphiura and Asteriana, there is an anomaly in the mode of development of the embryos that are provided with a larval yolk and have a very short larval stage (H. de Lacaze-Duthiers, Metshnikoff). Moreover, Amphiura is viviparous.

In his beautiful research on parasitic castration Giard (59), has called attention to the fact that hermaphroditic echinoderms (Amphiura and Synapta) have especially numerous parasites. For the 
synaptids, a mollusk Entoconcha, brown bodies (gregarines) reported by Leydig and Belin in 1853, very numerous infusorians of the group of urceolarians free in the coelom, etc. for Amphiura, some crustacans, Cancerilla tubulata Dal., and another copepod reported by Fewkes, an orthonecid, Rhopalura Giardii, etc. In most of the parasitized individuals, as usually happens, the gonads are atrophied because of the expense occasioned by the parasites. Now, in Amphiura, according to Metscnikoff, it sometimes happens that the ovaries along are castrated and the testes always remain active. Giard concludes that parasitic castration is more favorable than unfavorable for Amphiura because it prevents the disastrous results of self-fertilization in making physiologically dioecious a species originally hermaphroditic.

I cannot associate myself completely with these conclusions. First of all, the number of parasitized individuals is extremely minimal and there are no dioecious echinoderms in which the parasites are at least as numerous as in Synapta and Amphinura ${ }^{46}$

I have not found parasites in Asterina gibbosa that is also hermaphroditic. I thus believe authorized to say that the preference of parasites for the hermaphroditic species is much more apparent than real.

As for the case of Amphiura, it is useful to remark that cross fertilization is very probably the rule. Parasitic castration of the ovaries in some individuals thus does not change much from the physiological point of view and can have only the favorable result that Giard suggests. It is easy to understand why in the case of parasitic castration, the ovaries alone disappear and the testes remain active. The animal, exhausted by parasites, cannot be equal to the very considerable expense because of the large size of the eggs and their richness in yolk. The ovaries thus fail to develop whie the testes that require much less can keep their activity.

Amphiura squamata is a very cosmopolitan species (Atlantic Ocean, Mediterranean Sea) and vey abundant in localities whee they exist. This is not surprising. If it true that it spawns a very small number of eggs, it must not be forgotten that all or nearly all do well. The embryos enclosed in the bursae pass there the critical period of their existence, by escaping the multiple causes of destruction to which the free plutei are exposed. An Amphiura contains a minimum of 10 or 12 embryos and produces sometimes several spawns per year. It thus is actually much more favored than ophuroids that produce a large number of eggs, of which a large number are perhaps not fertilized and of which many embryos perish during the free period. Thus is explained the considerable distribution of this small species.

It is curious to note that the three hermaphroditic echinoderms that we just studied have different types of hermaphroditism. In Synapta, the hermaphroditism is the general case where the gametes, while formed in the same gland, are not mature at the same time (pulmonates, several lamellibranchs). In Amphiura, the male and female organs are separated in the same animal, as in numerous worms. As in the cestodes, self-fertilization is possible although probably it does not happen often. The case of Asterina gibbosa is most interesting. It is protandric hermaphroditism, the animal first being male, then exclusively female in the adult state. According to Cunningham and F. Nansen, it is the same in a vertebrate, Myxine glutinos $a^{47}$. Up to a length of 0.32 to $0.33 \mathrm{~m}$, it functions as a male. Past this size, it produces only eggs. It is the same in the cymothoides $(\mathrm{P}$.

\footnotetext{
${ }^{46}$ According to Schneider, Holothuria tubulosa often has numerous parasites (gregarines, crustaceans, and turbellarians). Crinoids have a very large number (Myzostoma, Stylifer, Stylina, various crustaceans and protozoans). Ophiothrix fragilis from Roscoff often contains numerous Distomes enkystes (probably a new spcecies. I have not seen it repored in Linstow and Monticelli), etc.

${ }^{47}$ F. NANSEN. Un hermaphrodite protandrique, Myxine glutinosa, parmi les Vertebrés. Bulletin scientifique de la France et de la Belgique., v. 20, 1880, p.315., (Translation)
} 
Mayer) among the crustaceans and rhabodonemids (Rhabdonema nigrovenosum, etc.) among the nematodes. This protandric hermaphroditism can be compared to the existence of complementary dwarf males (progenetic males) of ciripedes (Darwin, Hock, etc.). In fact, these dwarf males are considered as a persistence of the young or larval state (progenesis) of the hermaphroditic form.

\section{ASEXUAL REPRODUCTION}

We know that some ophiuroids and asteroids reproduce by simple autotomy, each fragment containing a part of the three layers, endoderm, mesoderm and ectoderm. The autotomy is called medial when the animal divides into two nearly equal parts, as in the ophiuroids Ophiocnida sexradia Duncan (according to Duncan and Ludwig), Ophiothela isidicola Lütken and dividua von Martens, Ophiocoma pumila Ltk. and Valenciae M. and T., Ophiactis virens Sars, Mülleri Ltk., Savignyi M. and T. (according to Sars, Steenstrup, Verrill, von Martens and especially Lütken) and a large number of asteroids: Asterias tenuispina Lmk., calamaria, microdiscus Stimpson, acutispina Stimps., atlantica Verrill, Stichaster albulus, Cribrella sexrdiata Perr. (143), Asterina Wega Perr. (according to Perrier, Cuénot, figures in 28), etc.

The schizogony is called radial when the arms are detached from the disk and each forms a new individual as in the Linckiadae, (Ophidiaster cribrarius Ltk., Linckia diplax, ornithopus. multiforis, Ehrenbergii, Guildingii).

The process of regeneration has been especially studied by Simroth (169). It is anyway not complicated and I have nothing to add to the descriptions of the German author. In Ophiactis virens, sexual reproduction does not coincide with asexual reproduction. In fact, in individuals whose $\mathrm{D}=1$ to $2.5 \mathrm{~mm}$ and that certainy divide constantly, there is no trace of gonads. I have found the mature stage only in an individual whose $\mathrm{D}=4 \mathrm{~mm}$ and consequently at the maximum size and showing no trace of recent schizogony. Perhaps sexual reproduction occurs only when the individual reproduces many times by autotomy. Lütken makes an analogous remark for Ophiocoma pumila and Valenciae. All young individuals (up to $4 \mathrm{~mm}$ ) have six unequal arms and reproduces evidently by autotomy. To the contrary, those reaching $5 \mathrm{~mm}$ have no more than 5 arms and no longer appear to divide. There would thus be for these species a kind of alternation of generations in the literal and original sense of the word. Young individuals reproduce in an asexual way, the adults by the sexual way.

In Asterias tenuispina, Asterina Wega and according to Lütken in Stichaster albulus (Asterias problema), it is not so. The dividing individuals have perfectly developed gonads.

Specificity of autotomy. - It is probable that autotomy is a true specific character for the species that I have just listed. Can it be an anomaly in the other species that do not usualy reproduce by autotomy? The few examples that we have cited are still very doubtful. It is probable that the authors have had in their hands individuals in the process of regeneration after a great trauma. Comet specimens (those coming from radial autotomy) have been described by Martens Echinaster fallax (with six arms), by Esmark, John Dalyell, Lütken, Perrier, Schleiden in Asterias rubens and glacialis, by Perrier in Mithrodia clavigera, by Sars in Brisinga coronata, by Studer in LabidiasterI, etc. It is possible that in the number, there are some that really represent reproduction (abnormal) by radial autotomy, but I must note with Lütken, at least for Asterias, that the alleged comet specimens have a normal central disk. They have evidently lost by autotomy four of their arms. The central disk alone remains with a ray that procedes to regenerate the missing 
parts, which gives a superficial resemblance to the comet form of Linckiadæ I can confirm that this happens, at least for all the comet specimens of Asterias rubens and glacialis that I have had in my hands.

As for the specimen of Ophiopsila aranea described by Semon (166), in which a new disk is formed in the middle of a large arm, I completely agree with the conclusions of Ludwig that we see there a regeneratin of three arms and part of the disk (113).

\section{MORPHOLOGICAL VALUE OF THE ARMS AND RADIUS}

Because of the presence of five nerve bands that run the length of the body, the body of echinoderms is divided into five sections. In synaptids, holothurids, pelmatozoans, primitive urchins, the division of the body into five sections is completely exterior, the body keeps its globulose form. Moreover, in all these types, the pentagonal symmetry is absolutely constant and normal. All the monstrosities described keep the characters of anomalies confirming the rule. They are anyway very rare. The monstrosities by default (tetramerous or trimerous examples) and those in excess (hexamerous examples) probably owe their origin to a primordial anomaly of the water ring that has produced a number of buds more or less than five. Sometimes the anomaly of number of ambulacral zones is accompanied by an anomaly of internal organs or of the apical pole. But often it does not retain the organization of the animal. Finally, when there is an increase or decrease in an ambulacral zone, it does not occupy a fixed place and can be found between any two zones.

Ludwig (111) has described five hexaerous individual Cucumaria Planci. The supplementary ray is intercalated between $\mathrm{C}$ and $\mathrm{D}$ of the bivium, sometimes to the right, sometimes to the left of the interradius CD. Carpenter and Dendy have encountered hexamerous Antedon and Actinometra.

Hexamerous individuals are particularly numerous in Amblypeustes (Stewart ${ }^{48}$, Haacke (64), Discoïdes $^{49}$, Hemiaster (Cotteau in H. batnensi ${ }^{50}$, Gauthier in H. latigrunda ${ }^{51}$, etc.

$\mathrm{V}$ Koenen ${ }^{52}$ mentions two tetraradial species of Encrinus liliformis, Carpenter three tetraradial specimens of Antedon and Actinometra. Haacke (64) and Bell have found tetramerous Amblypneustes. Cotteau figures a Discoïdea cylindrica with four ambulacra (Paléontologie française, t. 7, 1862-67), Echinides du terrain crétacé). Finally, we know even an Echinoconus vulgaris having only three radial zones.

We see that these anomalies keep an exceptional character. It is completely different in asteroids and ophiuroids. In these animals and in crinoids, the body hitherto globulous narrows in the interradius and takes a more or less star-shaped form. The disk and the arms are differentiated. But the arms are nothing else than a simple indentation of the disk. It is completely impossible to increase the value of buds, analogous to those of a salp or a syllidian. In fact, no one will dispute that an ophiuroid or an asteroid is absolutely homologous to an urchin for example and there is nothing added. The form is simply different. Now, as it is impossible to pretend an urchin has buds, it is equally impossible to say it of an asteroid or an ophiuroid. Finally, a bud, in the strict

\footnotetext{
48 STEWART (175) in Amblypneustes griscus; Haacke in undetermined Amblypneustes.

49 DESOR. Monographie d'Échinodermes (3e livr Galerites). Neuchatel, 1812.

50 COTTEAU. Echinides nouveaux, 1869, p. 150, pl. 20.

${ }^{51}$ GAUTHIER. Assoc. franc. pour l'Avanc. Des Sc., t. 13 (see pl. 7).

${ }^{52}$ V. KoEnen. Uber Muschelkalk-Encriniten, N. Jahr. Min. Geol. Pal., bd. 2, 1887, p. 86.
} 
sense of the word, contains the three layers: ectoderm, mesoderm and endoderm. The buds of salps, syllidiens, etc. have these three parts, but is not the same for the arms of crinoids, ophiuroids, young asteroids and adult Hymenodiscus (Perrier). In fact, these have only the ectoderm and the mesoderm. It is only in the adult asteroid that the endoderm is extended into the arm in the form of radial caeca (it is not rare to find arms that lack digestive caeca). Haacke (63) and I have found this in Asterias rubens and glacialis). We see thus that in crinoids, ophiuroids and asteroids, the radius, instead of constituing simple layers of the body, are separated more or less. Consequently, we can remove them without the animal suffering greatly, and they can regenerate them very rapidly. In asteroids, another process takes place. Not only are the arms very cleary separated from the disk, but consequenty the endoderm enters into their interior. They have secondarily acquired the value of individuals, of merides. If we detach them, they can continue to live for some time and in which case (Linckiada), they can produce a new animal, which is understandable because they contain all the organic systems and even gonads.

In summary, the radii that are first of all, do not forget, simple superficial divisions of the disk, can little by little form rays and acquire in higher forms a true individuality (asteroids), so much so that, separated or not from the disk, they can sometimes produce a new organism (see notably the various monstrosities figured by Sarasin (158) in Linckia multiform, showing all the intermediaries between bifurcation of an arm and the formation of a new asteroid at the distal end of the radius). Naturally, there is nothing there that resembles a colony of animals or a budding at the expense of the central animal. It is simply a decentralization (Semon and Perrier have reached analogous considerations).

In asteroids and ophiuroids, another phenomenon occurs: The normal number of rays is no longer necessarily five. It can reach up to 40. Among the ophiuroids (leaving aside those that reproduce by autotomy), Ophioglypha hexactis Smith, Ophiacantha anomala Sars and vivparai Lgm., normally have 6,7 or 8. The anomalies of number in the five-armed asteroids are extremely frequent (Asterias, Asterina, etc.). The new arms can be either produced directly from the edge of the mouth or result from a branching of an old arm, a branching that develops and ends in turn by producing a mouth so that one cannot distinguish the new arm from that which produced it. It is by this process that new arms are produced in well-developed Labidiaster radiosus (Perrier). We find all intermediaries between the formation of new arms between two older arms and the traumatic or normal bifurcation of an arm (see notably in Sarasin, a very complete history of asteroids with bifurcated arms, 158). This phenomenon is absolutely distinct from true budding (because the endoderm does not intervene). It is rather, as Herdmann says, an irregular tendency to dichotomy.

We see that the asteroids that we have considered as the terminal group of echinoderms have indications of a paticular evolution: $1^{\circ}$ the animal is decentralized to take a radial appearance (like crinoids and ophiuroids). $2^{\circ}$ the various antimeres formed three layers, ectoderm, mesoderm, and endoderm, become relatively independent and can by separation become a new animal. $3^{\circ}$ The number 5 no longer has its fateful value. The rays can be any number, variable even in individals of the same species. Finally, the rays can bifurcate of even trifurcate at their end or at any point along their path, processes that can end in the formation of new arms intercalated between the old ones. This phenomenon is always inconstant and irregular and never reaches dichotomous division so regular in the arms of crinoids or euryalids.

It is useful to note that all these differentiations are secondary and that in their young age, all asteroids and ophiuroids show a stage if not globulose, at least pentagonal that remains fixed in 
adult Astrophiura Sladen, Palmipes, Asterina, Ctenodiscus, Pentagonaster, Nidorellia and Culcita.

\section{SECOND PART}

\section{PHYLOGENY OF ECHINODERMS}

To my mind, the long preceding study is in a way only an introduction to the phylogeny of the group. Now we are going to try to use the accumulated material and revised with all possible care in order to deduce the path of evolution of echinoderms. These animals lend themselves better than all the others to such speculation. Indeed, they are separated in such an absolute way from all other families that there is not a doubtful echinoderm, not a single transitional type to forms more or less related. The original source is certainy unique and the question is presented in the most simple form that one can imagine. Finally, thanks to their skeletal covering, many echinoderms of geological times are preserved up to now. Paleontology gives precious indications that are generally lacking in other groups. We see that all are united to make the work relatively easy.

It is necessary to indicate the means by which we can reconstruct the genealogical tree of echinoderms.

From the preceding, it follows that this work is based on the evolutionary theory that has been formulated by Lamarck. If the transformational theories that investigate the causes of this evolution are all more or less questionable, it is not the same with the evolutionary theory that is too often confused with them. I am absolutely convinced that all echinoderms descended from a common ancestral form and that we are perfectly justified in investigating, dismissing all explanatory theories, what was the path of this descent. Paleontology will be of no help to us. In fact, all echinoderms appear perfectly distinct from each other from the most distant past, from the Cambrian and the Silurian. The small differences in appearance that we have noted between the various groups have no importance because of the difficulty of the investigations and the relative rarity of specimens. We have only the celebrated law of parallelism between phylogeny (development over time) and ontogeny (development of the individual)) or the fundamental biogenetic law that is, it seems to me, very poorly understood. We accept that an individual shows during its normal development (i.e., not condensed by secondary reasons, so that a formation of yolk, an intra-maternal development, etc.) passes very rapidly through the various phases that its ancestors have gone through over time. The point of view is completely wrong, as Carl Vogt has noted in his clever Hérésies Darwinistes ${ }^{53}$. It is wrong for the type considered in itself, but not for its organs. I explain what I mean. A mammal, for example, in the course of its ontogenetic development, does not pass all the stages taken by its ancestors. There is nothing comparable to a tunicate, a cyclstome or a reptile, certainly. But, and this is the point I am trying to make, all its organs separately pass through the ancestral stages. Thus the vertebral column obviously passes through a series of fixed stages of the adult animals (tunicates, fish and reptiles. The same branchial arcs, the heart, the limbs, etc. But at the moment where the heart, for example, is at the fish stage,

${ }^{53}$ CARL VOGt. Congrès des Naturalistes suisses à Genève, 12 Aoât 1880 (Revue Scientifique). 
if I can express myself in this way, it is necessary for the other organs, the skeleton, the nervous sysem, the limbs to be in comparable stages.

Each organ or each system develops on its own, conforming to the laws of heredity, but while some go very quickly, because they are indispensable to a short time, others go more slowly, This produces a mixture of very developed organs and undeveloped organs, absolutely incomprehensible if we follow to the letter the fundamental biogenetic law, perfectly clear and explicable if we accept that it is true only for the isolated organ alone.It follows that the only way to investigate evolution of a group is compare the organology of different organic systems without taking account of the relative order of appearance. To better understand this, I am going to take an example among the echinoderms. Without wanting to prejudge the relation of crionoids to the other groups, it is perfectly evident that crinoids with a stalk derive from species without a stalk that had the rest of their organs more or less similar to those of their successors: a water vascular system, a nervous system, gonads, etc. If the biogenetic law were true to the letter, we would find at a certain moment a well developed crinoid, but without a stalk, then a little after, another stage with a stalk in the process of formation, etc. It is far from being thus. The stalk becomes indispensable as a means of fixation. By a series of steps, to accelerate development, it is formed earlier and earlier in the young, so that now in Antedon rosacea, the stalk is formed and then attaches when the ciliated bands still exist, before the skeletal plates are connected, before the mouth is open and the tube feet tentacles are formed. We thus see very clearly that it is not necessary to consider the relative order of appearance of organs and that it is necessary only to study in themselves to deduce phylogenetic conclusions.

In summary, by comparison of different stages taken by the organs and their fixation in the in the different types, $1^{\circ}$ I have sought to establish the genealogical tree of the group; $2^{\circ}$ I have accepted as actual homologies only various modifications of the same organ existing in the ancestor, all the rest being ony more or less complete analogies.

Paleontological results. - Another word about the use of information provided by paleontology. Many authors and notably Darwin have emphasized how fragmentary is the information it provides. We must utilize it but not make it a base of operation. It is even truer for the relative date of appearance of the various forms. The anti-evolutionists, Barrande foremost, have not lost the opportunity to note how little they agree with extant forms. In fact, sometimes they agree with them, sometimes they absolutely contradict the most well-founded predictions of zoologists. It is that the date of appearance of a fossil sometimes does not correspond at all with the real apperance of the type on the globe, as it is taught in an all too absolute way, but represents only the period where has become abundarnt for one reason or another, so that it is found in synchronous layers that have become characteristic. But this does not mean that it did not exist before in a more or less sporadic state. I am going to demonstrate it by a typical example. It is undemiable that all the urchins descended from a primitive form whose stone canal opened outside by a single pore. When young, all have this stage. Now, a single urchin, Echinocyamus pusillus, has as an adult this ancestral character, and so clear that it does not seem to me possible to explain the fact by retrogradation, a stop in development, etc., especially since this species keeps a large number of primitive characters (a single sphaeridia per radius; nearly all the tube feet connect with their ampula by a single pore, very projecting terminal tentacles, a digestive tube with a simple spire, spines having kept the primitive lattice form). Logically, this Echinocyamus that has kept these traits characteristic of the ancestors should appear very early, before all those that have a more complicated madreporite, numerous sphaeridia, etc. It is not the case. Echinocyamus appears for the first time in the Upper Cretaceous, after a large number of regular or irregular urchins with 
compex madreporites. From the evolutionary point of view, an uninterrupted chain should connect Cretaceous Echinocyamus with Precambrian ancestors with a single madreporite pore. However, so far no one has discovered a mesh. What should we conclude from this? Quite simply that paleontology gives only very incomplete information and what is considered the time of appearance of a species can correspond only to the moment when this species becomes sufficiently abundant that in the small surface of explorable land we have some chance of encountering its remains. That is to say, to the contrary of Agassiz and Lovén, we shall use mainly the deductions furnished by the study of living animals and that the paleontological information will take only a second place.

Phylogenetic theories. - We have given some phylogenetic theories that scarcely agree among themelves. It is necessary to recognize it. I shall concern myself only with those exclusively related to echinoderms without searching their relations with coelenterates or worms.

The first of these by date is that of Hockel (1866). He considers the asteroids (formed by the fusion of five worms) as the origin. The crinoids are separated first, then the echinoids and in the last place the holothuroids (adopted by Gegenbaur, O. Sars, Lange). A very large number of authors have accepted the first proposition of Hœckel, especially considering the nervous system of these animals that has the most primitive characters, notably Marshall (1888), Hamann (1887) and Perrier (1888). This view seems all the more sustainable because the asteroids appear very early in Cambrian deposits.

Semper (18868) tends to derive the asteroids and echinoids from the holothuroids, the holothuroids having themselves by synaptids many connections with gyphyriiens.

A. Agassiz (1872) found in the young stages of echinoids, asteroids and ophiuroids an archaic form that he did not define, but that is very similar to a synaptid. These animals, as well as the crinoids, will go through a "holothuroid stage."

The crinoids strictly speakinig have often been considered as the souce of urchins, asteroids and ophiuroids, especially in investigations of the homologies of the skeleton (Lovén, H. Capenter, P. Sladen, etc). Perrier spoke often of the cystids or the fixed crinoids as the origin of all echinoderms.

Semon (1888) based himself on the fact already reported by Agassiz and perfectly correct that all echinoderms go through in their young age a similar larval form approaching that of the synaptid (Pentactula of Semon), Imagine a hypothetical type, fixed to the soil by a stalk, the Pentactea, from which all the others would be derived.

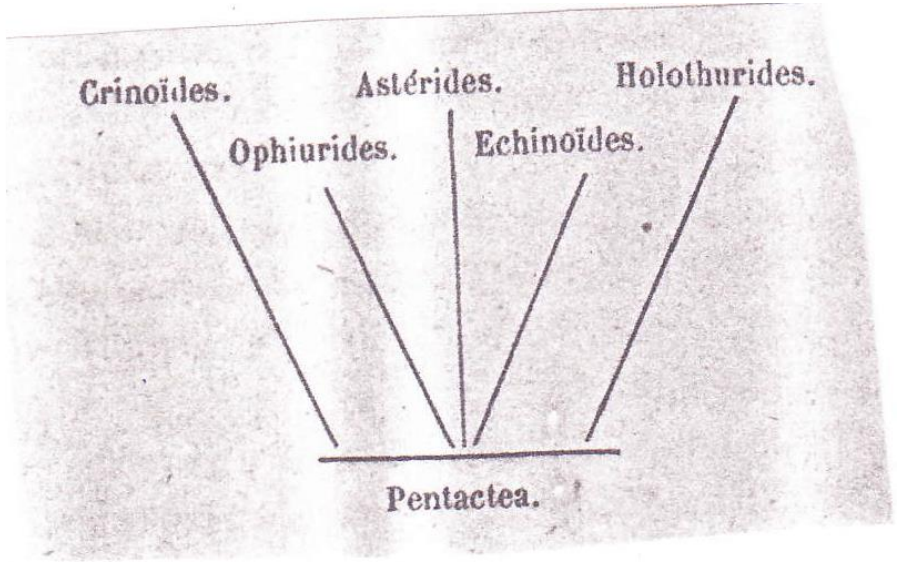


But Semon has made a gross error that discredits his results. The primary tentacles of the synapta (interradial tentacles) are homologous with the radial water canals of other echionoderms. No more than Bury, I cannot accept this point of view that led Semon to unacceptable results: notably to propose that the holothuroids on one hand and the other echinoderms on the other hand have diverged immediately after the formation of the primary tentacles and that the nerves and radial water canals are produced independently in each group. Hamann has likewise criticized Semon's ideas from this point of view. The young urchins, ophiuroids and asteroids are still identical to each other, well after the "Pentactea" phase has passed. It is evident that the radial water canals with their terminal tentacles and their tube feet have been transmitted from one group to the other, while in the hypothesis of Semon, it is necessary to regard them as having independent formationl This is why, while accepting as true the type Pentactea, we reject completely the genealogical tree proposed by Semon.

The same year, I have tried to establish the phyologenetic relatioins between urchins, ophiuroids and asteroids. I can now confirm and clarify what I published at that time.

Neumayr (1888), mostly according to paleontological documens, considered the cystids as the original form. On one side, they gave rise to the blastoides and crinoids by the intermediary of Codaster and Cystoblastus on one hand and Porocriniius on the other hand. From the other side, they gave rise to the ophiuroids and asteroids by Paleodiscus and Agelacrinus and to echinoids by Cystocidaris. Naturally, the holothuroids have no place in this picture. The first proposition seems completely acceptable to me, but it is not the same for the second.

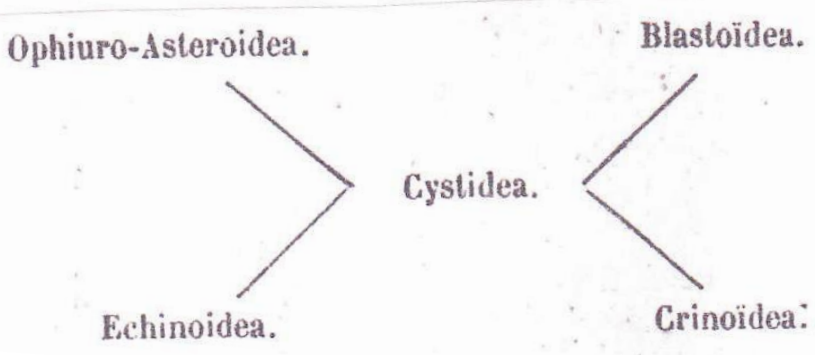

The urchins, ophiuroids and asteroids have too many similarities among them to have diverged separately from all the cystids. These three forms are obviously related to each other (radial gonads, axial gland, apical skeleton, etc). The ophiuroids and the asteroids do not appear to be dirieved directly from the cystids. There are too great real differences for us to accept this hypothesis.

Sturtz (177) accepted the views of Neumayr about the descent of asteroids (Ophiuridæ and Stelleridæ). It is the same for Hoernes (Traité de Paléontolgie).

For the cousins Sarasin (1888), it is the holothuroids that represent the original form. One one side detach the cystids (source of the Pelmatozoa), and another the echinoids, and a third probably the ophiuroids and asteroids. 


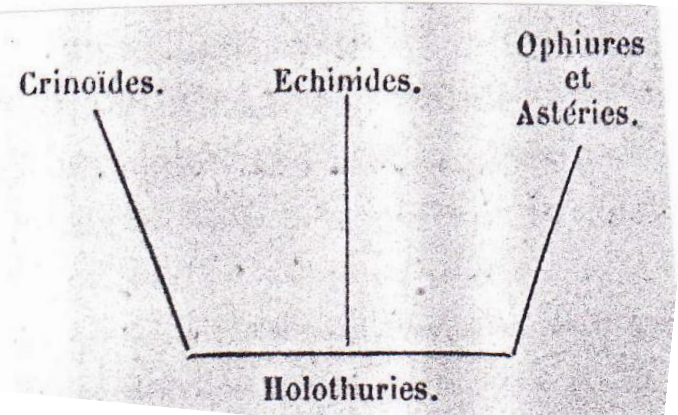

The authors were led to this conclusion by comparison of echinothuroids on one hand and the cystids on the other hand with some extant holothuroids, notablyPsolus. But I will criticize the Sarasins for having compared some details of structure that are not even homologues, such as the feeding apparatus of urchins and the pharyngeal bulb of holothuroids, the blastopore of young holothuroids and the secondary anus of cystids. This greatly reduces the value of their deductions.

Hamann (1889), while having some reservations about the subjective nature of genealogical investigations, produced a theory that seems to me little compatible with morphological observations. For him, the parental stock of echinoderms is formed of two branches. One of them is that of asteroids, with echinids represent a derived form. The holothuroids descended in their turn from the echinids by retrogradation. The second is that of the crinoids that produced the branch of ophiuroids.



I think that Hamann has based his comparison only on the nervous system, but he has reached conclusions truly impossible to accept. It is obvious that ophiuroids are very near asteroids and not at all to crinoids.

None of the preceding phylogenetic theories have had a rigorous starting point. Sometimes they have the error of making extant groups descend from each other like Hœekle and the Sarasin cousins. Sometimes they are based on the examination of some organismal sysgems without including all, like Semon and Hamann. I shall proced completely otherwise. Each group, synaptids, holothuroids, pelmaozoans (cysideans, blastoids, crinoids), echinoids, ophiuroides and asteroids has an ancestral form that can be will defined. These are the diverse ancestral forms A, B. C. D. E that descent from each other and not from extant groups. Or to say it better, there is no transitional form between the synaptids, holothuroids, pelmatozoans, etc., while there are beween thir respective ancestors $\mathrm{A}, \mathrm{B}, \mathrm{C}$ etc. These are thus the first ones that must be defined. 
A. The common ancestor of synaptids will be Prosynapta (identical or very near the Pentactea of Semon), whose characters can be defined in this way: globulose of elongated body with calcareous spicules, straight digestive tube with the blastopore as the anus, superficial nervous system formed of five thick ectodermal bands joining an oral ring, continuous with the endodermal wall of the esophagous (stage present in young synapids, Semon), water apparataus formed of an oral ring with five interradial tentacles and a stone canal opening to the exterior by a single pore (form shown in all young Synapta and Chirodota studied, probably a Polian vesicle opposite the stone canal. Five radial schizocoelic sinuses. No lacuna system. Gonads forming a group in the holothuroid plane, as in adult synaptids.

B. The common ancestor of holothuroids (elasipods, molpadids, holothuroids) will be Proholothuria: globulous or elongated body with unconnected calcareous plates; straight or spiral digestive tube, with the blastopore as the anus. Nervous system like Prosynapta. Water system formed of an oral ring with five radial branches with tube feet; stone canal opening to the exterior by a single pore (fixed stage in some elasipods), probably a Polian vesicle opposite it, the radial water canals ending in projecting tentacles, arranged in circle around the blastopore (terminal tentacles atrophied in part in adult holothuroids). Five radial schizocoelic sinises. No lacunar system. Gonads like Prosynapta.

C. The common ancestor of pelmatozoans (cystids, blastoids, crinoids) will be Procystus: gloobulous body (resembling more or less cystids or blastoids) lacking a stalk, integument incrusted with calcareous plates (one dorso-central and several superimposed ranges and alternating with symmetrical penetamerous plates). Digestive tube in form a globulous sac (we find this form in young Antedon before the opening of the secondary anus), no anal opening (the blastopore is closed in Antedon and it is only later that the secondary anus opens). Superficial nervous system (fixed stage in extant crinoids for the ectodermal system). Water system formed of an oral ring with five radial branches with tube feet (stage shown by cystids and blastoids with arms); single stone canal (stage shown temporarily by Antedon and probably fixed in cystids ${ }^{54}$. Five radial schizocoelic sinuses (persisting in neocrinoids). Gonads placed in the holothurian plane (it is there we find inn the cystids the opening that all authors interpret as the gonopore).

D. The common ancestor of echinoids would be Proechinus: globulose body entirely covered with calcareous plates, forming at the apical pole a defined ensemble; a dorso-central, a row of five interradial plates (basals), a row of five radial plates (terminals). Digestive tube without anus (the blastopore is closed as in the pelmatozoans and there is a secondary anus opening at a different place from that of pelmatozoans). Superficial nervous system. Water system formed of an oral ring with five radial branches with tube feet and ending in an unpaired tentacle in contact with the terminal plates (stage in all young urchins); stone canal opening to the exterior by a single pore (stage in all young urchins, fixed in Echinocyanus pusillus), probably without relation to a calcareous plate. Five radial schizocoelic sinuses and perhaps an oral schizocoelic ring. No masticatory apparatus (fixed in Atelostomata) nor lacunar system. The axial enterocoel, rudimentary in Prosynapta, Proholothuria and Procystus, takes a great development. In its interior is developed a lymph gland (axial gland). The gonads, always formed on the wall of an enterocoelic cavity, are radial.

E. The common ancestor of asteroids and ophiuroids will be Proaster: body having a pentagonal form (transitory in all young asteroids and ophiuroids, fixed in Culcita, Asterina,

\footnotetext{
${ }^{54}$ In Aristocystites Bohemicus, according to Barrande, there are four openings: the central that is the mouth; one lateral, covered with a valve of five plates that corresponds to an anus; between them are two very small openings (gonopore and stone canal?).
} 
Palmipes, Astrophiurida Sladen, etc.), covered with calcareous plates. At the apical pole is a dorsocentral, a row of basals, a row of terminals; between the two latter is a row of new radial plates, the radials. Digestive tube in form of a globulose sac without an anus (fixed stage in ophiuroids and some asteroids). Superficial nervous system (fixed stage in asteroids). Water system identical to that of urchins (fixed in adults, with terminal tentacles (conserved in adults) and stone canal with a single pore (fixed ini many ophiuroids). Five radial schizocoelic sinuses, opening into an oral ring; this system is in communication with the coelom on one part and the axial enterocoel on the other. The latter is well developed and encloses the axial gland that produces the gonads. Radial gonads.

However hypothetical it may appear, the reconstruction of ancestral types rests on morphological principles accepted by everyone. For prudence, I have not wanted to push too far the details of the systems, but I am convinced that by the process of organogenesis, compared with the fixed stages in adults, we shall get to know them as well as the extant types.

In the order that I have arranged them, we can note that the ancestors A, B, C, D, and E follow perfectly and form an uninterrupted chain without sensible gaps. This is what I show graphically in the adjacent genealogical tree.

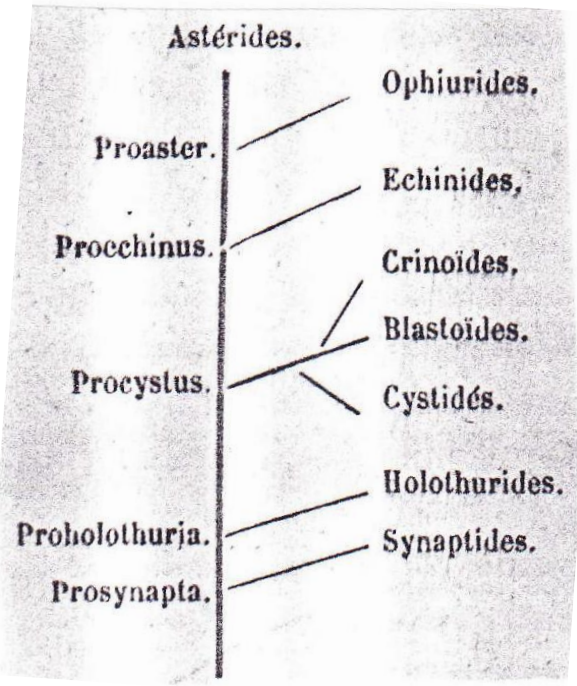

In order to prove the reality, it is necessary to find in each group a reminder of immediately preceding ancestral types: so the asteroids must pass ontogenetically by the forms Prosynapta, Proholothuria, Procystus and Proechinus. That is what I am going to try to demonstrate.

Prosynapta or Pentactea, as we would like to call it, is found in young holothuroids, while the radial canals are not at all developed and the five primordial tentacles alone exist. Then this stage is passed. The radial canals and the tube feet take a great development, the peribuccals are strongly differentiated from the others.

In pelmatozoans, the question is a little more difficult because there are at the present time only crinoids much more separated from the primitive group than the fossil groups. Sometimes it is evident that the cystids, as pointed out by Walther (183) and the Sarasins (159), show holothuroid symmetry (gonopore in the same vertical plane as the anus, the mouth and the apex). The cystids and the blastoids have the globulose form characteristic of synaptids and holothuroids. It is certain that in Antedon the blastopore is closed: the digestive tube has thus to be deprived of an anus; it reopens only a little later, no longer at the apex but in interradius BC. It is possible that in Procystus the occlusion of the first anus is related to the exaggerated development of the 
calcareous plates. The superficial nervous system of Prosynapta and Proholothuria is perfectly conserved in extant crinoids. The water system of neocrinoids, while there is only a single stone canal, is identical with that of the preceding types except for one dissimilarity: the first interradial tentacles, fixed in synaptids and transitory in holothuroids, no longer appear, at least in Antedon rosacea. It is also the same in the following echinoderms, but this can be explained rigorously by an acceleration of development that suppresses useless organs. Before bifurcation of the arms, the young Antedon has five terminal tentacles like Proholothuria.

In echinoids, the blastopore, at first the primitive anus (Pluteus) is closed as in the pelmatozoa. It is only later that forms in variable places a secondary anus. It is quite certain, although this has not be directly confirmed, that at its origin, the nervous system is entirely superficial, as in Procystus. The water system first is a simple oral ring (Prosynapta stage), becomes identical to that of Proholothuriia. The terminal tentacles are well developed and persist even to the adult state. The stone canal opens to the exterior by a single pore as in the preceding ancestral types (persisting in Echinocyamus pusillus). That which very clearly separates the urchins from the preceding types is the very rapid appearance of the gonads and the development of the axial gland, an organ appearing for the first time.

In asteroids and ophiuroids, the blastopore, at first the first anus, is closed as in Procystus and Proechinus. The digestive sac remains closed in a large number of species. The seconday anus opens into the interradius BC. The apical skeleton is at first completely identical to that of urchins. In young asteroids, as concordant studies by Lovén, Ludwig, Bury and Fewkes, we find at the apex a dorso-central, a row of basals and a row of terminals, i.e., an apical pole of the urchin. The radials that take a great development appear later. There is sometimes a contradiction reported for the ophiuroids: the apical skeleton is formed at the beginning, from the dorso-central, a row of radials, and a row of terminals (Ludwig, Bury, Fewkes). The basals form a little later. In young Ophiothrix echinata, whose disk diameter measures a half-millimeter and the arms a millimeter, the dorsocentral and the five radials fill completely the aboral surface of the disk. The basals appear at this moment in the form of very small plates. Their appearance is thus very late. Perhaps we can explain this precocious formation of the radials (according to Fewkes, they would appear first in Amphiura) by the great importance that they take in ophiuroids. It is they, in fact, that consolidate first of all the aboral surface of the disk.

The tube foot nervous system remains superficial in adult asteroids. It is the same in the young (ophiuroids). The water system is first formed of a simple oral ring (Prosynapta stage), becoming identical to that of Proholothuria or Proechinus. In the young, the stone canal opens to the exterior by a single pore (persisting in numerous ophiuroids). The terminal tentacles persist throughout life. The relations of the gonads with the axial enterocoel and the axial gland are identical to those that exist in urchins.

$\S$ We see that the phylogenetic grouping that I just outlined is verified by ontogeny. We can still bring other arguments in its favor. I think we cannot dispute that the synaptids and the holothuroids represent well derivatives of the most primitive forms, as shown by the reduction of the dermal skeleton, the persistance of the blastopore as the anal opening, etc. This is what Semper, Agassiz, Sarasin and Semon thought, the differences in detail set aside. On the other hand, it is equally indisputable that the urchins, ophiuroids and asteroids form one completly having obvious affinities (axial gland, axial enterocoel, radial gonads, apical skeleton, etc) that force considering them as coming from two or three very near ancestral types.

Finally the cousins Sarasin (159) have brought out the resemblance of holothuroids and cystids, whie Lovén and other authors have described the transition form (apparent!) between 
blastoids and urchins (Tiarechinus princeps Laube). All these results are a priori perfectly in agreement with my genealogical tree.

If we accept it as true, we can make some unexpected and truly interesting consequences: $1^{\circ}$ the most ancient types, i.e., the synaptids and holothuroids, are also the most differentiated and those whose organs are separated more from the echinoderm type. We can say that the organs, having had more time to evolve, are transformed more than in the recent groups. It is true for the nervous system that has lost all original connections with the ectoderm and esophagus. For the water system, whose stone canal what now opens into the coelom, etc. To the contrary, the more recent types (asteroids and ophiuroids) have kept intact a larger number of ancestral characters (nervous system, water system, etc.).

$2^{\circ}$ The special differentiations and new formations of organs seem nearly constant in relation to the respective age of the groups. Thus, in the three most ancient, synaptids, holothuroids and crinoids (except some abysal exceptions), the stone canal opens into the coelom, while it has kept its connections with the exterior in the three recent groups. The enterocoel annexed to the stone canal, rudimentary and transitory in the synaptids, holothuroids and crinoids, takes a great development and encloses a glandular organ in urchins, ophiuroids and asteroids. In the four ancient groups, it has developed a lacunar system (absorbing intestines, etc.), that again is lacking in the two recent groups. The enterocoelic nervous system, in contrast, which is missing in the two ancient groups, is developed in the others, crinoids, asteroids ophiuroids and urchins. The gonads, bilaterally symmetrical in synaptids, holothuroids and probably cystids, have become radial in urchins, ophiuroids and asteroids. There is not even the form of the body that seems to evolve equally. The organism is more or less globulose in synaptids, holothuroids, cystids, blastoids and urchins, to become clearly radial in ophiuroids and asteroids, the projection of the radius being weak in the young to gradually increase. I could multiply these examples that agree very remarkably with the genaology that I propose.

$\S$ To complete this phylogenic history of echinoderms, we must refer back to the above. We can easily recognize a gastrular stagr (when the archenteron of the gastrula is still simple), a coelenteric stage (Metschnikoff), when the archenteron has two peritoneal vesicles (this stage will be very near to that which is fixed in young ctenophores, Cydippe among others ${ }^{55}$, and finally a larva with a digestive tube and a well defined coelom with bilateral symmetry, with a circumoral ciliated ring, and a particular nervous system, also bilateral ${ }^{56}$. The different larval forms of echinoderms (Auricularia, Bipinnaria, Pluteus, etc.) represent only coenogenetic modifications of the Dipleurula stage (Simroth). The Dipleurula is derived from the hypothetical Prosynapta, which differs especially in the formation of the water system and the differentiation of five ectodermal nerve bands.

It is obvious that from the Dipleurula form is separated only the stem of echinoderoms, which has no transition type to neighboring phyla. As a consequence, it is the Dipleurula alone that can have affinities with the other bilateral larvae. It is to it that attention should be addressed when we try to attach them to the other diverse phyla that make up the Animal Kingdom.

\footnotetext{
${ }^{55}$ METSCHNIKOFF. Studien ueber die Entwickkung der Medusen und Siphonophoren, Zeitschr. für Zool. für wiss. Zool., Bd. 24, 1874, p. 13.

KOWALEVSKY and MARION. Documents pour l'histoire embryogénique des Alcyonaires, Ann. du Musée d'hist. nat. de Marseille, t. 1, 1883, mém. $n^{\circ} 4$.

${ }^{56}$ METSCHNIKOFF. Embryologische Mittheilungen über Echinodermen, Zool. Anz., Jahrg. 7, 1884.

SEMON. Zur Morphologie der bilateralen Wimperschnüre der Echinodermenlarven. Jenaische Zeits.für Naturw., bd. 25, 1890, p. 16.
} 
A fact that is very certain and accepted by all is that the echinoderms are derived from a clearly bilateral form probably allied to other bilateral larvae of enteropneuses, trochozoans, etc. How has it acquired radial symmetry? Some think that it is because of fixaton. I do not think so. Radial is in control in Prosynapta because of the presence of five primary tentacles and five longitudinal nerve bands allthough the digestive tube, gonads, etc. have kept bilateral symmetry. We can easily conceive how the skeleton later took a radial symmery, to which the gonads and finally the digestive tube yielded. We see that in the last analysis, the appearance of radial symmetry is due to the presence of five equal tentacles emitted by the water ring and the existence of five ectodermal thickenings making up the nervous sysem. As to the cause of this development, naturally we can know nothing about it.

Finally, I shall only raise a queston, entirely metaphysical. Has the evolution of echinoderms ended in our time? I do not believe it. I think the the asteroids can still evolve and be profoundly modified, especially in the sense of decentralization of the arms and protection of the still exterior nervous system.

\section{ClasSifiCATION.}

It is not useful to insist on the fact, now accepted by everyone, that natural classification must be solely based on phylogenetic relations that exist between the different forms that concern us. It is according to this principle that we shall divide the echinoderms into six classes: I. Synaptida; II. Holothurioidea; III. Pelmaozoa; IV. Echinoidea; V. Ophiuroidea; VI. Asteroidea.

I. Synapatida (Apeumona of Semper and Théel). - All authors combine this order or suborder of synaptids to the holothuroids. However, in our present state of knowledge, it seems indispensable to me to separate these two types because they have two distinct ancestors ${ }^{57}$.Either the synaptids are degraded holthuroids as Théel thinks and then the ancestral Prosynapta must be suppressed, or the synaptids derived from a different ancestor from that of holothuroids. Here are the reasons that I reject the first opinion. $1^{\circ}$ The primary tentacles kept in adult synaptids are no longer clearly found in the holothuroids. $2^{\circ}$ Radial water canals are lacking in synaptids. Its water system is completely primordial. It would be incomprehensible for it to descend from holothuroids. In fact, the radial canals exist in all known species of the latter group with the doubtful exception of Eupyrgus (Echinosoma Semper, Even in molpadids, that are surely degraded holothuroids, there are buccal tentacles, radial canals with lateral rudimentary tube feet and probably terminal tentacles. $3^{\circ}$ The schizocoelic sinuses and the lacunar system are very different in synaptids and holothuroids. This would be incomprehensible in the hypothesis of a direct descent. Thus, with Semon and the Sarasins, I think the synaptids represent descent from the most ancient source (Prosynapta) and that they have no direct ancestral relation with holothuroids. I insist on this point that is essential for the construction of the genealogical tree of echinoderms. As for the common characteristics of the two classes (calcareous crown, longitudinal muscles, spiral digestive tube, Polian vesicle, stone canal opening into the coelom, etc.) either they result either from convergence or quite simply these systems existed in the same state in the ancestral Prosynapta and Proholothuria. The calcareous crown that has no other reason for being but to provide for an insertion for the radial longitudinal muscles can very well have been acquired separately in each group.

\footnotetext{
${ }^{57}$ It is for the same reason tht Delage has separated the Kentrogonides (Sacculina) from the cirripedes.
} 
II. Holothurioidea. - This class is distinguished from the preceding by the modification of the primary interradial tentacles and especially by the acquisition of radial waer canals, tube feet and terminal tentacles.

The first group that is separated from the common source is obviously that of the elasipods (Théel). Several of its representatives have kept the ancestral character of the stone canal.The calcareous crown is often at an embryonic state. There are no long respiratory trees. As for their very obvious bilateral symmetry, I think, to the contrary of Théel (180), that it has been secondarily acquired, as in Stichopus, Mülleria, Psolus and Colochirus, and that it not at all primitive. It is obviously an adaptation, in the same way that embryos of Cucumaria have first a much more marked bilateral symmetry than that of the adult with a very sensible dominance of the ventral water canal of radius $\mathrm{A}$.

All holothuroids other than the elasipods are characterized by the acquisition of respiratory trees and their stone canal opening in the coelom. These are Pneumophora (Semper), divided naturally into two groups: the Pedata (aspidochrotes and dendrochirotes) and the Apoda (molpadids) that are represented by the degenerate pedatids in which a large part of the radial water canal is atrophied.

In summary, our conclusions in regard to the holothuroids and synaptids agree in broad lines with those of Semper (168, p. 185),

III. Pelmatozoa. - Following H. Carpenter, Wachsmuth and Springer, etc., I have taken the name Pelmatozoa created by Leuckart in 1848.This class contains three orders: cystids, blastoids and crinoids (Eucrinoidea Zittel). If it is already very difficult to disentangle the phyletic relations of the present groups, we can think that the thing is nearly impossible for the extinct groups of which we know only a few species. It is certain that there is a considerable hiatus between the pelmatozoans and the preceding echinoderms so that we are reduced to conjectures about the primitive forms of the group. The soft body of Proholothuria is encrusted with calcareous plates so much that the blastopore is closed. The animal is attached by the aboral pole and a new anus is opened in interradius $\mathrm{CD}$. The ambulacral grooves are sensibly shortened, all remaining superficial (as in the cystids Glyptospharites, Callocoystites, Agelacrinius, Edrioaster, Hamicsites, etc.). The cystids and blastoids show in addition, particular appendages (that we call very improperly arms and pinnules) that certainly de not correspond (as least the arms of cystids) to that we designate by the same name in crinoids. There is no reason to consider, with Lovén (118), the ambulacral groove of cysgtids as lowered arms fused to the calyx.

I willingly consider the blastoids (such as Pentremites) as less separated from the origin than the cystids as least in the simple composition of the calyx. It is true that we find very clearly transitional forms between these two orders. As for the eucrinoids, characterized by the predominance of the calyx and the entire ambulacral zones that become arms ramified into pinules, some authors have derived them directly from cystids while others (Wachsmith and Springer, Walther, Zittel) think that the cystids and crinoids diverge from a common source with bilateral symmetry. Walther thinks that the genera Atelocystites from the Lower Silurian and Macrosystella from the Cambrian belong to this hypothetical primordial order. The point of view seems to me much the most reasonable. All there is for ceratin is that there still is much to clarify regarding this question.

IV. Echinoidea. - To divide the urchins, I shall take as the fundamental character the presence or absence of a masticatory apparatus that which determines two orders: Atelostomata and Gnathotomata. This classification is necessarily artificial, but I believe that it is best at this time because the phylogeny of urchins is extremely complex and obscure. 
A. Atelostomata. - It is extremely probable that all atelostomes descended from a form with a masticatory apparatus because we have found no trace of its ontogenetic development. But, on the other hand, many authors think that the cassiduloids without jaws, that have so great a resemblance to the gnthostome echinoconids, are separated from the latter group by atrophy of the masticatory apparatus $^{58}$. It is thus very possible that the order of atelostomes is artificial in that it contains groups (like spatangoids and holasteroids) descended from an ataelostome ancester and others (like cassiduloids) descended from an ancestral gnathostome whose masticatory apparatus atrophied little by little. For the moment, I consider this question as insoluble.

The atelosome ancestor would have as characters: the mouth at the center of the oral surface and pentagonal in form (young spatngoids pass through this stage, which is fixed in Paleostoma and numerouds casssiduloids); the anus at the apical pole, either endocyclic (see studies of Lovén on Hemiaster cavenosus) or more probably exocyclic in contact with the basal AB (all young spatangoids pass through this stage, fixed in Hyboclypus); tube feet communicating with the ampoule by a single pore (fixed stage in Pourtalesia); straight ambulacral zones, all alike. The various families have separated little by little from the ancestral form by differentiation of the petaloid zones and especially by the accentuation of bilateral symmetry due to the emigration of the anus and the mouth.

B. All the urchins with jaws derive very probably from a common ancestor differing only from the atelostome ancestor by the acquisition of the masticatory apparatus. They are divided naturally into three orders. $1^{\circ}$ Irregulars or clypeasteroids that have kept on one hand a large number of ancestral characters (one spheridea per radius, most tube feet communicating with their ampulla by a single pore, gonopores ouside the apical system, digestive tube making a single spiral, stone canal and terminal tenticles of Echinocyamus pusillus), and on the other hand, are differentiated by the formation of petaloid zones, migration of the anus, mixing of calicinal pieces and accentuation of bilateral symmetry. It is very possible that the order of irregulars is artificial because the echinoconids, which resemble so much the regulars by their straight ambulacra, their rounded form and buccal gills, could well derive from another source than the clypeasteroids strictly speaking. As for the origin of the cassiduloids, I content myself with asking the question that appears to me extremely difficult to resolve.

$2^{\circ}$ The regulars form the second order of gnathostomes. They have clearly conserved the radial symmetry of the ancestor, but they are separated from it by the structure of the tube feet, communicating with the ampulla by a pair of pores, complication of the digestive tube, multiplication of the sphaeridia, etc.

$3^{\circ}$ The palechinids form the third order, entirely extinct and predominating primarily in the Paleozoic period, is considered by most authors as the source of all gnathostomids. I believe instead that it is a lateral branch completely separated at the beginning of the source of regulars. In fact, it has a large number of secondary characters that nothing indicates they could be considered primitive (multiplication of interambulacral plates in the perischoechnids, often imbricated as in Lepidocentrus; multiplication of the terminal and gonadal pores in Melonites and Palaechinus. In the true regulars, these characters show from another time attempts, so to say, that are essentially adaptive and secondary. The multiplicity of the interambulacral plates exists in Tetracidaris Reynesi Cotteau (Neocomien). The imbrication of the plates in the echinothurids and a diademid, Pelanechinus corallines (Upper Jurassic). The multiple termina pores in the

\footnotetext{
${ }^{58}$ The fact is that for many urchins (for esample Craterolampas Cotteau), we do not know of we should place them after the gnathostomids or in the atelostomids, although we have no information on the presence or absence of a masticatory apparatus.
} 
arbacioids, the multiple gonadopores in a large number of urchins (anomaly). We see that the palechinids, far from appearing, in spite of their ancientness, as primitive forms, have traces of a long evolution that, in summary, has moved them much farther from the ancestral type than the present regulars.

V. Ophiuroidea. - The ophiuroids are clearly separated into two orders, connected by diverse transitory forms: the true ophiuroids with simple arms and the euryalids with ramified arms. In some Paleozoic ophiuroids (Ophio-Encrinasteriæ Stürtz), the discoid ossicles are divided into two halves that, instead of corresponding exactly, alternate with each other. These are Protaster (Forbes, Billings, Hall, Gregory; Taniaster Billngs, Eugaster Hall, Paleophiura and Bundenbachia Stürtz, This is not a special group that is set off because, in very close species (Protaster Salter), the halves of the ambulacrals correspond perfectly. They are rather attempts of adaptation that have taken place simultaneously in several families. Also, like Stürtz, we leave these aberrant ophiuroids in the group of true ophiuroids.

VI. Asteroidea. - The asteroids or stelleroids are clearly distinguished from the preceding groups by the form of the skeleton, the regularly radiated appearance and the superficial nervous system. It is a very homogeneous class and it seems to me useless to divide it into large artificial sections as attempted by authors. I shall discuss only the classification of Bronn, adopted by Zittel and Stürz. Bronn separates from the normal stelleroids (true asteroids) the Paleozoic order Encrinasteriæ in which the ambulacral pieces alternate instead of corresponding. For us, the encrinasteries are not a defined group, clearly separated from true asteroids. They are rather adaptations that have been produced separately into various groups of asteroids. In fact, most of the species completely resemble each other except for the character stated above, with diverse species with corresponding ambulacral pieces. Paleasater, notably, has completely the features of Pentaceros and even for many others. It is this that Stürz perceived. He placed his encrinasteries into the families of Palebrisingidae (Loriolaser, Cheiropteraster), Palegoniasteridae (Aspidosoma, Paleaster), Palasterinidae (Palasterina), Palechinasteridae (Palasteriscus), etc.

The encrinasteries often have another secondary character, the madreorite is located on the oral side, between the corners of the mouth (Cheiropteraster, Pakasteriscus, Aspidosoma). But this character is far from being constant. It is the same in a true Paleozoic asteoroid, Echinasterella Stürz and in Helianthaster rhenanus (that Stürtz referred to the euryales, but that seems to us must be referred to the true asteroids because of the large number of ams). On the other hand, the madreporite is in its normal location, on the aboral side, in numerous encrinasteries (Paleaster, Palasgterina), We see that it is much more logical to consider the asteroids with alternating ambulacrals as being isolated adaptations of normal asteroids and not at all a separated order descended from a single ancestor.

$\S$ It is truly curious to note that the three classes of echinoids, ophiuroids and asteroids are represented in the early times by aberrant branches that have taken to this time a very great development and then disappear after the Paleozoic period. These aberrant branches, palechinids, ophio-encrinasteries, encrinasteries that most authors consider wrongly as the source of echinoids, ophiuroids and asteroids, show very numerous secondary characteristics of a kind that the forms that continue until now have more the ancestral appearance than the Paleozoic forms. These aberrant branches, very differentiated, already witness a long evolution.

I summarize, in the form of a table, the classification I propose: 
VI. Asteroidea.

V. Ophiuroidea. $\quad$ Ophiuræ.

Euryalæ.

IV. Echinoidea.

\begin{tabular}{|c|c|c|c|}
\hline & $\begin{array}{l}\text { Gnathostomat } \\
\text { a } \\
\text { Atelostomata. }\end{array}$ & $\begin{array}{l}\text { Palechinoiden } \\
\text { Regulares. } \\
\text { Irregulares. }\end{array}$ & \\
\hline III. Pelmatozoa. & $\begin{array}{l}\text { Cystidean. } \\
\text { Blastoidea. } \\
\text { Crinoidea. }\end{array}$ & & \\
\hline II. Holothuroidea. & $\begin{array}{l}\text { Elasipoda. } \\
\text { Pneumophora. }\end{array}$ & Pedata. & $\begin{array}{l}\text { Aspidochirota. } \\
\text { Dendrochirota. }\end{array}$ \\
\hline
\end{tabular}

I. Synapatida.

I do not conceal the imperfections from myself. I have based it on some hypotheses. But perhaps some of them are correct. Anyway, all classification is by its nature temporary and indefinite and attempts of adaptation that have taken place simultaneously in several families. In spite of the iimmense number of known facts, we never know so well those that remain to be learned as when we attempt the synthesis of a group. In summary, the preceding list is nearly in agreement with the classifications proposed b various specialists, Semper for the holothuroids, $\mathrm{H}$. Carpenter for the pelmatooans, Agassiz for the echinoids, etc. It differs especially from the usual classifications adopted: $1^{\circ}$ by the separation of the synaptids that I have tried to justify above; $2^{\circ}$ by the relative order of the different classes in relation to the succession of the respective ancestors.

I do not believe it is useful for me to give a detailed critique of the various classifications propsed by the authors. They are all more or less acceptable. But as none has taken for the point of departure the phylogenetic sequence of the different classes, it follows that they are very artificial.

Comparison of our conclusions with paleontological information. - We have already stated our reservations on the subject of the value of paleontological information. Because of their fragmentary state, it is impossible to build a reasonable theory of evolution of echinoderms as for the other phyla.

For the origin of the different classes, paleontology provides no useful information. In fact, from the most ancient formations known, the various types of echionoderoms appear well developed and little different basically from extant forms. The crinoids and cystids appear in the Cambrian (Lingula flags) and the Lower Silurian (Llandeilo and Caradoc), the echinoids in the Lower Silurian (Bothriocidaris of Estonia), the asteroids and ophiuroids in theCambrian (schist of Bala in Wales). Given the rarity of specimens, there is no conclusion to draw from the small 
differences in the order of appearance, as Zittel has correctly noted. It is very possible that the urchins existed in the Cambrian although we have not found them. It is thus since the Cambrian (which represent an enormous amount of time) that the echinoderms evolved and were transformed.

As for the phylogeny of each particular class, I am sorry to say that paleontology is nearly always contradictory with the best established deductions. Of two, chose one. Either the morphological theories on which we now rely are singularly erroneous or the paleontological data are so incomplete that we cannot take any account of the order and time of appearance of the species or groups. For my accouont, I prefer naturally the second interpretation. We add that if we want to base it solely on paleontology, we arrive at absurdities. It appears to me unlikely, for example, that urchins with two pores per tube foot appeared before those with only one pore, while this is the inverse of what occurs in ontogeny, or that a genus that goes from the Zechstein, the Triassic, the Jurassic and the Lower Cretaceous becomes extinct in the Cretaceous to reappear in the Eocene (Hemicidaris).

Among the pelmatozoans, the cystids appear in the Cambrian of England, Bohemia and Canada, i.e., in the most ancient fossiliferous layers. The crinoids probably existed also in the Cambrian but are recognizable only in the Lower Silurian of Wales. As for the blastoids, their venue is later, because there are ony two species known in the Upper Silurian of America. In summary, these facts are in near agreement with the morphological predictions. The cystids, by their conserved bilateral symmetry, the minimal development of the stalk, sometimes even absent, and the form of the ambulacral grooves are obviously much closer to the ancestral form.

Among the echinoids, we find during the entire Paleozoic period only palechinid gnathosomes, having numerous secondary characters that we cannot consider in any way as precursors to extant urchins. The gnathostome regulars that according to theory, should exist at the same time and even before the palechinids appear only in the Triassic (perhaps the Permian), with Cidaris, Hemicidais, Tiarechinus, etc. The most ancient genus of the irregulars (Pygaster) goes back only to the Lias (it is true that the branch of echinoconides is perhaps detached separately from the regular line). The best example of contradiction between theoretical prediction and paleontology is given by Echinocyamus. This species has characters so primitive that we should encounter it before the regulars and the known palechinids, appearing only in the Upper Cretaceous! The other clypeasteroids develop only after this period. This confirms the opinion that we gave above, the group of gnathostome irregulars is artificial because it contains two families separated from the common line at different times and without relation between them.

Among the Ateostomtata, I set aside the cassiduloids that could come from the line of regulars by atrophy of the jaws. Ther first genus (Galeropygus) appears in the Lias at the same time as the echinoconides, which they resemble so much. But the true atelostomes (holasteroids and spatangoids) that should precede all gnathostomes because they come from an ancestor with jaws, are found for the first time in the Middle Jurassic, represented by a slightly aberrant form (Collyrites). We see that the contradiction is complete in ithe current state of science. Perhaps it will disappear later. In any case, the purely paleontological theories on the phylogeny of urchins bring out the obscurity that rules on the origin of the great divisions, gnathostomes and ateolostomes.

The first asteroids and ophiuroids come from the Cambrian (schist of Bala). It is notable that these are aberrant forms, with alternating ambulacral pieces (Paleaster, Protaster). The normal asteroids (Senaser, Echinasterella, Helianthaster rhenanus, etc.) appear only in the Lower Devonian. The first euryalid (Eucladia) in the Upper Silurian. According to the theory, we should 
find at the same time normal asgeroids and those with alternating ambulacrals. But, as the fossils are very rare and often poorly preserved, the slight contradiction between the predictions and paleontology is not important.

In summary paleontology, except for the urchins, is not in contradiction with the phylogenetic theory developed above. But, for this class, it is impossible to reconcile at this time the theoretical predictions and the data. 


\section{EXPLANATION OF THE PLATES.}

\section{PLATE XXIV.}

Fig. 1. - Calcareous plate in process of developing in an embryo of Amphiura squamata, with many mesodermal cells arranged irregularly (alcohol, methyl green).

Fig. 2. - Biscuit-shaped corpuscles, Synapta inhorens, in various stages of development (alcohol, carmine). Mag. 540 times.

Fig. 3. - Decalcified section of the body wall, Ophiactis virens; $c u$, cuticle; $p$, peripheral layer strewn with black pigment and numerous nuclei; $x$, holes corresponding to the calcite removed by acid; $r$, reserve cells with proteinaceous granules; $e x$, scum granules

Fig. 4. - Section of the body wall, Cucumaria cucumis (picrocarmine, methylene blue); cu, cuticle encrusted with pigment; me, fibrillar connective tissue layer underlying the cuticle; $e c$, packets of ectodermal cells sunken into the mesoderm; lo, spaces filled with fundamental gelatinous substance; $n p$, branches of the peripheral nerve plesus leading to the ectoderm; $r$, migrating reserve amoebocyte. Mag. 375 times.

Fig. 5. - Section of the body wall, Synapta iniharens, passing through a glandular-sensorial mamelon; $n p$, peripheral nerve; $g n$, ganglion of he mamelon; $g l$, glandular cells; $s$, group of sensory cells. Mag. 375 times.

Fig. 6. - Protruding anchor of the skin, Synapta inharens (alcohol, methylene green); me, Structureless membrane of the anchor; $d$, membrane draped on the anchor and forming strong connective tissue bundles on its borders $f ; e p$, mass of mesodermal cells (pseudo-epithelium of Semper). Mag. 210 times.

Fig. 7. - Schematic section of a spine; $n p$, peripheral nerve; $g n$, ganglion of the spine; $n r$, spinal nerve; $f$; section of the ring of ligaments connecting the rod to the articulating mamelon; $m c$, central muscle of the spine.

Fig. 8. - Schematic section of a spine bordering the ambulacral groove of Asterias glacialis; ma, lowering muscle; $m r$, raising muscle whose fibers are mixed with connective tissue fibrils $f$.

Fig. 9. - Tridactyl pedicellaria of Echinocyamus pusillus; $f$, small muscle bundle connecting the valves of the calcareous shaft. Mag. 810 times.

Fig. 10. - Lower surface of the masticatory apparatus and beginning of the digestive tube, Peronella orbicularis; St, Stewart's organ; si, intestinal siphon; $g$, axial gland with a glandular oral ring.

Fig. 11. -Section of a ciliated urn perpencular to the longitudinal axis, Synapta inhoerens; en, peritoneal epithelium; $u$, urn in process of development; $p l$, mass of amoebocytes entrained in the ciliary curents; $m e$, longitudinal mesenteric strap; $m c$ circular muscles of the body wall. Mag. 210 times.

Fig. 12. - Wall of a ciliary urn, Synapta inharens (Flemming's solution, safarin); ex, granule of rabut; brightly colored by safranin. Mag. 625 times.

Fig 13. - Wall of the coelom, in a section at the anterior end of the body showing the enigmatic formations, Synapta inhorens; en, peritoneal epithelium, non-modified; f, small connective tissue nodule emitting radial fibrils. Mag. 1250 times. 
Fig. 14. - Section of the wall of a bursa, Amphiura squamata (alcohol, safranin); en peritoneal epithelium; ep, packets of cells with nuclei brighty colored by safranin. Mag. 540 times.

Fig. 15. - Amoebocytes from the body cavity, Synapta inhorens; $a$ and $b$, in vivo; $c$ and $d$, Flemmings's solution and safranin; $a$, muriform amoebocyte with colorless granules; $b$ amoebocyte with echinochrome granules; $c$, normal amoebocytes containing some granules of rabut, stained with safranin; $d$ normal amoebocyte.

Fig. 16. - Digestive tube of Echinocyamus pusillus; si, intestinal siphon connected to the intestine by mesenteric septum; an, anus; Mag. 7 times.

Fig. 17. - Section of a saccule, not yet completely mature, Antedon rosaceus; ep, internal epithelium. Mag. 400 times.

Fig. 18. - Cells of the saccule, in different states of development (osmic acid, distilled water, methyl geen); $e p$, basal cell; $p y$, pyriform mass of refringent granules; $f$, terminal filament.

Fig. 19. - Longitudinal sections of a tube of Cuvier, still attached to the cloaca, Holothuria impatiens; $g l$, glandular epithelium of cells in the gutter; $m l$, longitudinal muscle bundles; $m c$, circular muscle bundles (spiral muscle); $f$, spiral connective tissue; $c$, central cavity of the tube of Cuvier; $p$, basal portion of the tube lacking the glandular epithelium; $v$, basal vesicle, opening $d$ into the cloaca; $m c$ ', circular muscles of the basal vesicle; $f c$, cellular-connective tissue mass projecting into the basal vesicle. Mag. 40 times.

\section{PLATE XXV.}

Fig. 20. - Transverse section of the radial nerve band, Astropecten aurantiacus; lateral part of this section showing the nerve $n p$ ' leaving the deep nerve mass $n p r ; g n$, ganglionic nerve part (Lange's ganglion); $m l$, longitudinal muscles; $n$, epidermal nerve band continuous with the ectoderm $n p$.

Fig. 21. - Transverse section of the radial nerve band, Asterias glacialis; $n$, epidermal nerve band; $n a$, epithelial-nerve covering of a tube foot; $n p r$, deep nerve mass (Lange's nerve); $m l$, longitudinal muscles; $l r$, glandular septum of a radial sinus $s ; s$ ' diverticulum of the radial sinus going into the wall of the tube foot. Mag. 100 times.

Fig. 22. - Vertical section of the oral nerve ring (near the axial gland), Asterias glacialis; $n$, epidermal nerve ring; $n d$, epithelial nerve covering of the esophagus; $n p$, epithelial-nerve covering of the peribucccal pieces; $n p c$, deep nerve mass innervating the peribuccal pieces; $n p d$, deep nerve mass (perhaps inconstant) innervating the esophageal wall; $m$ circular muscles of the esophagus; $m c$, underlying circular muscles of the nerve ring; $s$, oral sinus; $s b$, transverse septum of the oral ring having in $a l$, a glandular ring; $a$, section of the water ring. Mag. 100 times.

Fig. 23. - Section of the coelomic wall passing through the longitudinal muscle of the arm, $m l$, and the central enterocoelic nerve ne; section made perpendicularly to the axis of the arm (osmic acid, alcohol, safranin), Asterias glacialis. Mag. 580 times.

Fig. 24. - Schematic section of an arm of an asteroid, showing the three nervous systems: $n$, epidermal nervous system, extending in $n a$ onto the tube feet and in $n p$, onto the wall of the body; $n p r$, deep nervous system; ne, enterocoelic nervous center covering the radial muscle of the arm $m l$. 
Fig. 25. - Vertical section of an embryo of Amphiura squamata in the bursa of the parent; $n$, oral nerve ring; still superficial and continuous with the wall of the digestive sac D; am, buccal tube feet; $t$, terminal tentacles; $a$, section of the water ring; $t$, stone canal; $p$, its external pore, still on the aboral surface (the embryo is in stage with 15 tentacles, measuring $240 \mu$ ). Mag. 312 times.

Fig. 26. - Transverse section of an arm of an embryo, Amphiura squamata (this embryo, still in the bursa, has a diameter of $250 \mu$ ); $n$, radial nerve band, still superficial; $r p$ calcareous fold bordering each side of the band; $b$, section of the radial water canal; $c u$, cuticle. Mag. 660 times.

Fig. 27. - Buccal tube foot of an embryo of Amphiura squamata represented in fig. 25; $a$, water ring; gna, tube foot ganglion; $r p$, calcareous fold surrounding the base of the tube foot.

Fig. 28. - Vertical section of the oral nerve ring, passing through an interradius, Ophiocoma scolopendrina; $n$, epidermal nerve ring; $n p c$, deep nerve ring; $n m$ ', nerve of peribuccal pieces; $n d$, nerve of the digestive tube; $\propto$, esophagus; $s$, oral schizocoeloic sinus; $s n$, epineural sinus; al, glandular-lacunar ring. Mag. 120 times.

Fig. 29. - Vertical section of the peristome, Ophiocoma scolopoendrina (passing thrugh line XY, pl. XXVI, fig. 30); $\mathrm{nm}^{\prime}$, muscle nerve, for the interrdial muscle $m i$, and the intra-muscle diverticula of the bursa $\mathrm{br} ; \mathrm{npm}$, nerve plexus underying the adoral interradial muscles (mia); $n d e$, dental nerves; $m d$, dental muscles (upper adoral interradius of Simroth); $n d$, nerve of the esophagus $\propto ; x$ and $y$, closed spaces determined by circular mesenteric septa; $p$, Polian vesicle; $n i$, interradial nerve; $n e$, enterocoelic nerve ring, located on the wall of the aboral sinus enclosing the genital cord $g$ "; $d$, teeth. Mag. 27 times.

\section{PLATE XXVI.}

Fig. 30. - Schematic of the arrangement of the nervous system, in the disk and the beginning of the arms, Ophiogypha lacertosa; the aboral wall has been removed; the animal is assumed to be entirely transparent; the schemataic has been constituted according a series of sections done in different directions; $p$, Polian avsicle, $o g$, gonads; $b r$, slit of the bursa; The Roman numbers give the order of the tube feet; I and II are the two pairs of the buccal tube feet; nlu, Ludwig's nerve; $n t$, integument nerve; $n m$, muscle nerve, for the muscle pairs uniting the disc ossicles; $n r s$, nerve of the unpaired radialis superior; $n l$, lateral nerve; $n i$, interradial nerve; nm', nerve of the interradial musce (interradialis aboralis of Simroth); npm, nerve of the dental muscles and of the teeth; ne, entercoelic nerve ring, indicated by a series of hyphens; $n p$ ', peripheral nerve of the aboral wall of the disk; XXY, direction of the vertical section represented in pl. XXV, fig. 29. Mag. 5 times.

Fig. 31. - Schematic of the nervous system, Ophiothrix fragilis; same letters as the preceding; $\mathrm{AB}$, direction of the vertical section in fig. 33. Mag. 5 times.

Fig. 32. - Schematic of the nervous system, Ophioglypha albida; same letters as the preceding

Fig. 33. - Transverse section of a radius, a little before the point where it leaves the disk (following AB, fig. 32), Ophiothri fragilis; mi, muscle connecting the disk ossicles; og, ovary; $b r$, end of the slit of the bursa; en, portion of the coelom, including the wall of the disk, the arm, and the vertical calcareous pillars $p i ; n a$, tube foot nerve; $n p$, peripheral nerve; $n l$, lateral 
nerve; $n p^{\prime}$, peripheral nerve passing into the aboral wall of the disk; ne, enterocoelic nerve ring, enclosed in the genital ring, with the genital cord $g$ ". Mag. 26 times.

Fig. 34. - Section of an arm, Ophioglypha albida; $n p$, branches of the peripheral nerve; $n a$, tube foot nerve; $n m$, ending of the muscle nerve; en, coelom of the arm (dorsal canal of authors). Mag. 50 times.

Fig. 35. - Section of the radial nerve band, Ophiocoma scolopendrina in the space including two successive tube feet; $n$, epidermal nerve band; $n p r$, deep nerve mass (Lange's ganglion), emitting muscle nerves $\mathrm{nm}$ (to the left, the section passes exactly by the origin of the nerve; to the right, a little beyond), $l r$, radial glandular lacuna; $s$, radial schizocoelic sinus; sn, epineural sinus; $b$, radial water canal. Mag. 200 times.

Fig. 36. - Section of the radial nerve band, Ophiocoma scolopendrina, at the level of a tube foot; $n$, epidermal nerve band emitting one after the other the tube foot nerve $n a$, and the peripheral nerve $n p$; gna, tube foot ganglion; $n a$ ', tube foot nerve; gn, spine ganglion formed on the peripheral nerve; $s n$, radial epineural sinus; $s n$ ', small epineural ring surrounding the base of the tube foot (compare with fig. 27); $m a$, muscle layer of the tube foot; $f$, connective tissue layer; $e$, epithelium of the tube foot; $b$, radial water canal; $b$ ', transverse branch ending at the tube foot; $s$, radial schizocoelic sinus; $l r$, radial glandular lacuna; $l r$ ', branch of the lacuna losing itself at the base of the tube foot; en, coelom of the arm; mi, bundles of muscle connecting the disk ossicles. Mag. 200 times.

\section{PLATE XXVII.}

Fig. 37. - Perpendicular section at the radius, touching the nerve ring to show the deep ganglion mass $n p r ; n m$, muscle nerve leaving the deep nerve ring; $m d$, muscles that transversely connect the pyramids of the masticatory apparatus; $n$, epidermal nerve band; $s n$, epineural sinius; $x$, portion of the peripharyngeal cavity; $l r$, radial lacuna applied against the nerve band, accompanied by two muscle cords $m$; Strongylocentrotus lividus. Mag. 175 times.

Fig. 38. - Transverse section of a radius, Strongylocentrotus lividus; sn, epineural sinus; $n$, radial nerve band; $s$, radial sinus; $l r$, radial lacuna, from which leaves a lacuna $l r$ ' that is lost at the base of the tube foot; $b$, radial water canal; $v$, valve at the end of the ampulla $v a ; b$ ' and $b$ ', the two canals connecting the ampulla with the tube foot; $m a$, layer of longitudinal muscle fibers; $f$, connective tissue layer; $e$, epithelium of the tube foot; $n a$, tube foot nerve passing $n a$ ' into the epithelium of the tube foot; $n p$, peripheral nerve mixed with the ectoderm enp; $s u$, suture of the ambulacral plates. Mag. 175 times.

Fig. 39. - Transverse section of a radius, Cucumaria cucumis, passing through the origin of the peripheral nerves and tube feet; $n$, epidermal nerve band; $n p r$, deep nervous system; $n p$, peripheral nerve dividing into numerous branches, of which one $\mathrm{nm}$ goes to the layer of circular muscles fibers $m c$; $n a$, tube foot nerve; $s n$, epineural sinus emitting a small cavity $s n$ ' accompanying the nerve of the tube foot; $s$, radial sinus; $l r$, radial lacuna; $b$, radial water canal; $r$, reserve amoebocyte in the nerve band. Mag. 212 times.

Fig. 40. - Radial section of the aboral pole, Synapta inharens, to show the end of the radial nerve band $n ; m l$, radial longitudinal muscles; $e$, ectoderm; $a n$, anal opening; $b c l$, straps connecting the cloacal dilation to the body wall. Mag. 32 times. 
Fig. 41. - Section slightly tangential to the aboral pole showing the terminal tentacles, Cucumaria cucumis; $t$, rudimentary terminal tentacles; $e c$, packets of ectodermal cells (see fig. 4 ); $\mathrm{am}^{l}$ and $\mathrm{am}^{2}$, the lat two tube feet of the radial zones. The other letters as before. Mag. 36 times.

Fig. 42. - Radial section passing through the terminal tentacle $t$, Echinocyamus pusillus; sn, epineural sinus; $n$, radial nerve band mixed at its end with the ectoderm $e ; s$ radial sinus; $b$, radial water canal; $c g$, cavity of the aboral ring (genital ring). Mag. 365 times.

Fig. 43. - Section perpendicular to a radius, Arbacia pustulosa, to show the two terminal tentacles, $t$ and $t$; $n$, radial nerve band; $b$, radial water canal that bifurcates to end at the two terminal pits. Mag. 44 times.

Fig. 44. - Two papillae of tentacles, Antedon rosacea, stained with safranin $e$, cells of the base of the papillae; $r$, filaments of unknown importance, brightly stained by safranin.Mag. 2500 times. Fig. 45. - Section of a buccal tentacle, Synapta inhoerens, passing through the nerve of the tentacle $n a$ ' and the sensory pits so and so', the first is sectioned exactly in the middle; the cilia have been figured according to a preparation in vivo; the second pit so' is sectioned a little tangentially; $n p$, branch of the nerve detached from the tentacular nerve; snp, numerous tactile endings going to the epithelium $e ; f$, connective tissue of the tentacle; $m a$, layer of longitudinal muscle fibers; $e i$, internal epithelium of the tentacle. Mag. 150 times.

Fig. 46. - Radial section of the peristome passing throuogh a spheridea, Peronella orbicularis; csp, cavity of the sphaeridia, $s p$, sphaeridia; gn, ganglionic nerve ring to which leads a nerve branch $n s p$; $e$, external epitheium; $s n$, epineural sinus; $n$, radial nerve band; $s$, radial sinus; $b$, radial water canal. Mag. 300 times.

Fig. 47. - Cavity of the sphaerida cut tangentially, showing the sphaerida and the ganglionic nerve ring gn, Peronella orbicularis. Mag. 800 times.

\section{PLATE XXVIII.}

Fig. 48. - Transverse section of the radial band passing through the two statocysts, Synapta inharens; $m l$, radial muscle divided at this point into two separate halves (compare with fig. 52); $n$, radial nerve band; note, nerve of the statocyst; ote, statocyst cut exactly in its middle on the left, a little trangentially on the right; otl, otolith; $s$, schizocoelic sinus crossed by the small connective tissue tracts; sn, epineural cavity, probably an artifact. Mag. 260 times.

Fig. 49. - Radial nerve with a statocyst, Elpidia glacialis; preparation obtained by removing the spicular layer; $n$, radial nerve band; $n p$, peripheral nerve losing itself in the skin. Mag. 145 times. Fig. 50. - Statoocyst of Elpidia glacialis. Mag. 720 times.

Fig. 51. - Statocyst of Synapta inhroerens. Mag. 1000 times.

Fig. 52. - Vertical section of the upper end, Synapta inhorens, passing through radius A and the middle of interradius $\mathrm{CD}$; to the left, the section has met a buccal tentacle; to the right the section passes exactly by the axis of the opposite tentacle; $a$, water ring; as, oral schizocoelic ring; $c$, calcareous crown; lge, genital lacuna, located between the divided wall of the gonad; $l m$, marginal lacuna of the intestine; Im', end of the marginal lacuna on one of the esophageal tracts; med, dorsal mesentery connecting the intestine to the body wall and enclosing within it the gonad and the marginal lacuna; $m e v$, small free mesentery; $m l$, radial muscle, $m p$, madreporite; $n$, radial nerve band; $n a$, nerve of the buccal tentacle; $o$, gonopore; $\alpha$, esophagus; og, cavity of the gonad; otc, statocyst not cut by the section; $p$, Polian vesicle; $s$, radial schizocoelic sinus; so, sensory pit of the 
buccal tentacle; $t$, stone canal; $v$, valve between the internal ampulla and the tentacle; $v a$, internal tentacular ampulla; $v a$, ampulla of the tentacle cut tangentially.by the section; $x$, periesophageal space communicating at several points with the coelom as indicaed by the arrows. Mag. 20 times. Fig. 53. - Vertical section of the oral pole in a gnathostomous urchin (reconstituted according to preparations of Strongylocentrotus lividus) passing through radius A and the middle of interradius $\mathrm{CD}$; $a$, oral water ring; $a l$, lacunar ring; $a m$, buccal tube foot not cut by the section; $a u$, section of the auricle; $b$, radial water canal; $b$ ' branch emitted by the canal going to the buccal tube feet; $b p h$, pharyngeal folds; $b r$, external gill, not encountered by the section; $d$, teeth; $f$, false; $l b$, peribuccal lip; $l g$, lacuna going to the axial gland; $l i$, large ligamentous mass supporting in the radius the pharyngeal folds (fusiform organ of Valenin); $l r$, radial lacuna separated by a septum of the lacunar ring and very dilated in its lower portion (pharyngeal lacuna); $m d$, muscular bundles transversely connecting the pyramids of the masticatory apparatus (interpyramidal muscles of Valentin); me, ligament on which rests the nervous system where it passes under the auricle; mpe, peristomial membrane; $m t$, muscles transversely connecting the Y-shaped pieces (musculi transversi of Valentini); $m x$, membrane surrounding the peripharyngeal cavity (membrane of the lantern of Valentin); $n$, radial nerve band; $n p r$, deep ganglionic mass (see transverse section, fig. 37); $\alpha$, esophagug; $p d$, tooth plume; $s$, radial schizocoelic sinus, obliterated where the nerve band passes under the masticatory apparatus; $s n$, epineural sinus; $s p d$, membranous sac enclosing the tooth plume (dental sac); $t$, stone canal; $v s p$, spongy vesicle; $x$, peripharyngeal chamber; $y$, compass $(\mathrm{y}-$ shaped piece).

Fig. 54. - Vertical section of the mouth of Spatangus purpureus passing through radius D and the middle of interradius AB; $a$, water ring; $a l$, lacunar ring; $b$, radial water canal; $l r$, radial lacuna; $m c$, muscles of buccal pieces; $m x$, membrane of the periesophageal cavity; $n$, radial nerve band; $\propto$, esophagus; s, radial schizocoelic sinus; sn, epineural sinus; sn', section of the epineural ring underlying the nerve ring; $x$, periesophageal cavity, separated from the radial sinus by a septum $s b$,

Fig. 55. - Transverse section of a radius on the oral surface, showing the polymorphism of the tube feet, Echinocyamus pusillus; am and am', tactile tube feet (perhaps locomotory); ams, sensory tube foot redued to an epithelial button; an, nerve ring at the end of the tube foot; $n$, radial nerve band; va, tube foot ampulla. Mag. 210 times.

Fig. 56. - Transverse section of a respiratory tube foot, petaloid zone of Echinodiscus biforis; $b$ ' and $b$ ", the two canals connecting the internal and external part of the ampulla; $e$, tactile mamelon, rich in nerve fibrils; enp, point where the peripheral nerve mixes with the ectoderm; $t r$, tract that separates the internal ampulla and the external tube foot. The arrows indicate the hypothetical direction of the current in the respiratory tube foot. Mag. 100 times.

\section{PLATE XXIX.}

Fig. 57. - Vertical section directed following the arrow $\mathrm{X}$ (fig. 58), passing exactly through the point whre the stone canal communicates with the enterocoelic axial sinus, Ophiothrix fragilis; amp, ampulla, probably of enterocoeic origin; $g$, axial gland; $g$ ", extension of the gland that produces the genital cords; $m$, small muscular cord sectioned transversely; $m i$, bundles of interradial muscle; $n i$, end of the interradial nerve; sea, cavity of the axial enterocoelic cavity; $t$, stone canal; $z$, opening of the connection of the tube with the axial sinus. Mag. 170 times. 
Fig. 58. - Schematic of interradius CD in Ophiothrix fragilis, reconstituted according to serial vertical sections; $a$, water ring; amp, ampoule a; $b r$, bursa; slit; $b r$ ', origin of he intramuscular diverticulum; $g$, axial gland; $g$ ", genital cord; $m i$, path of the interradial muscle; $p$, external pore of the stone canal; $t$, stone canal; $z$, point where the stone canal opens into the enterocoelic siniius; $X$, direction of the vertical section represented in fig 57 .

Fig. 59. - Vertical and tangential section of the disk, perpendicular to a radius, directed following arrow X (fig. 61), Ophiactis virens $(\mathrm{D}=4 \mathrm{~mm}) ; b$, radial water canal; $g$ ”, genital cord; $n l$, lateral nerve (compae with fig. 30); $o$, gonopore; for the one on the right, we see sperm escaping outside; $s d$, digestive sac sectioned tangentially; te, very convoluted testis and encountered several times by the section, especially in the interradial pouch to the right; vac, water vessels of the coelom (vasa ambulacralia cavi of Simroth); vac', water vessels of the coelom passing across the gonads. Mag. 34 times.

Fig. 60. - Red blood cells without nucleus of Ophiactis virens.

Fig. 61. - A slightly schematic section of an Ophiactis virens whose $\mathrm{D}=2 \mathrm{~mm} ; a$, water ring, $a m$, first pair of buccal tube feet; $b$, radial water canal; $d$, tooth; $p$, Polian vesicles; $s d$, portion of the digesive sac encountered in the section; $t$, stone canal; vac, vessels of the coelom; $X$, direction of the vertical section represented in fig. 59.

Fig. 62. - Vertical section of a buccal tentacle of Synapta inharens, almost cutting the calcareous crown (compae with the right tentacle of fig. 52); am, cavity ofo the buccal tentacle; $c$, calcareous crown; $m a$, longitudinal muscles of the tentacle; $r p$, connective tissue projection, on which rests the blades of the valve $v ; v a$, internal tentacular vesicle. Mag. 35 times.

Fig. 63. - Vertical section of the oral rings and the stone canal, Peronella orbiciularis; $a$, water ring intricated with the spongy ring $a l$; $œ$, wall of the esophagus; $t$, stone canal. Mag. 180 times.

Fig. 64. - Vertical section of the stone canal in an embryo of Amphiura squamata whose disk measures $680 \mu$; amp, terminal ampoule; $g$, axial gland in process of develment; $m i$, interradial muscle; $p$, water pore; sea, wall of the enterocoelic axial sinus; $t$, stone canal. Mag. 812 times.

Fig. 65. - Vertical section passing through the point of origin of the genital cords, Ophioglypha albida whose $\mathrm{D}=3.5 \mathrm{~mm}$; $c g$, cavity of the enterocoelic aboral sinus (aboral ring); $g$, axial gland; $g$ ”, genital cord full of sexual cells; sea, cavity of the axial sinus; $t$, stone canal sectioned transversely. Mag. 200 times.

Fig. 66. - Transverse section of the aboral rings, Ophiocoma scolopendrina; $c g$, cavity of the ring; cs, mass of sexual cells (Genitalröhre of Hamann); $g$ ”, genital cord; ne, enterocoelic nerve ring. Mag. 190 times.

Fig. 67. - Transverse section of the aboral ring at the point where it supports an ovary, Ophioglypha lacertosa; $b r$, wall of the bursa; $c s$, mass of sexual cells continuous with the internal epitheium of the ovary; $c g$, cavity of the aboral ring; $g$ ”, portion of the glandular-lacuna of the genital cord; $m$, small muscle bundle sectioned transversely (compare with fig. 57, $m$ ); $n e$, enterocoelic nerve ring; $o$, gonopore, still incomplete; $o v$, cavity of the ovary; $s g$, genital sinus. Mag. 190 times.

Fig. 68. - Transverse section of the aboral ring, made exactly in the middle of a radius, Asterias glacialis; $c g$, cavity of the aboral sinius; $c s$, mass of sexual sells; $c s^{\prime}$, poorly defined mass of sexual cdlls mixed with lymph nuclei; $g$ ”, glandular portion of the genital cord; $l g$ ", irregular cavities filled with fine albuminous coagulum; $m l$, longitudinal muscle of the arm; $n e$, enterocoelic nerve center. Mag. 125 times. 


\section{PLATE XXX.}

Fig. 69. - Vertical section of the madreporite of Echinodiscus biforis, direction following the arrow X (fig. 70); $c g$, cavity of the enterocoelic aboral ring; $c g^{\prime}$ ', portion of this cavity that goes around the gonad; $g$, axial gland; $g$, glandular process; $l c g$, lacuna in the wall of the aboral ring; $l g$, lacunae in the axial gland and the wall of the axial sinus; lge, genital lacuna; $m p$, madreporite; $n e$, genital nerve ring; $p g$, genital papilla; $r$, protecting spines; $s b$, small septum connecting the glandular process to the wall of the axial sinus; of the aial siniuios; sea, cavity of the axial sinus; sea', terminal cavity in which is located the glandular processes; $t e$, testis filled with mature sperm; $t$, stone canal; $t t$, terminal tentacle; $z$, point where the stone canal communicates with the axial sinus, as indicated by the arrow. Mag. 45 times.

Fig. 70. - Schematic of the apical pole of Echinodiscus biforis, seen from the external surface and assumed transparent; the radii have been designated by the letters A, B, C, D, E; $c g$, outline of the aboral ring; $g$ ', place occupied by the glandular process; $m p$, madreporite pores; $o$, gonopore; $t$, location of the stone canal; $t t$, terminal pore.

Fig 71. - Vertical section of the water pore, Echinocyamus pussillus; amp, ampoule of the stone canal (compare with fig. 58); $c g$, cavity of the aboral ring; $g$, axial gland; $g$ ', glandular process; $p$, single water pore; $r$, spine; $t$, stone canal; $z$, point where it communicates with the axial sinus. Mag. 250 times.

Fig. 72. - Vertical section of the madreporite of a very young Strongylocentrotus lividus at the beginning of the formation of the gonads; $c g$, cavity of the aboral ring, communicating with that of the axial sinius as indicated by the arrow; cs, primordial sexual mass produced on the enerocoelic wall; $g$, axial gland; $g$ ', glandular process; lge, genital lacuna; $m p$, madreporite canalicules; ne, genital nerve ring; $o g$, gonad whose wall is covered with a single layer of nondifferentiated seual cells; $o$, gonopore; $s b$, septum connecting the glandular process to the wall of the axial sinus; sea, cavity of the axial sinus; sea', terminal cavity in which is located the glandular process; $t$, stone canal not cut by the section; $z$, lateral opening by which the stone canal communicates with the cavity of the axial sinius. Mag. 250 times.

Fig. 73. - Cells of the primordial sexual mass, Strongylocentrotus lividus.

Fig. 74. - Horizontal section of the pharyngeal water bulb of Cucumaria Planci, passing exactly through the point of origin of the stone canal; $a$, water ring; $e x$, mass of yellow granules (excretory products) accumulated in the connective tissue; $l m d$, dorsal marginal lacuna entirely transformed into a compact gland; $m c$, circular muscles of the intestine; $m l$, longitudinal muscles; $n d$, connective tissue wall containing numerous nerve branches; $\alpha$, epithelial wall of the esophagus; $o t$, opening of the stone canal into the ring; $t$, stone canal; $t r$, esophageal tract; $x$, peripharyngeal cavity. Mag. 40 times.

Fig. 75. Horizontal section of the pharyngeal waer bulb of Holothuria impatiens, passing a little above the water ring; al, lacuna ring transformed into a compact lymph gland; med, dorsal mesentery containing the gonoduct, $o$; $\alpha$, section of the esophagus; tr, esophageal tract; $x$, peripharyngeal space; $v$ small villosities of the glandular ring. Mag. 45 times.

Fig. 76. - Formation of the gonads in young Holothuria impatiens (length $0.085 \mathrm{~m}$ ); cs, poorly defined mass of sexual cells, enclosed in the lacuna that produces the gential caeca; lge, lacuna in the wall of the genital caeca; Imd, dorsal marginal lacuna; $\operatorname{lm} v$, ventral marginal lacuna; $i$, intestine; med, dorsal mesentery; $o$, gonoduct. Mag. 20 times. 
Fig. 77. - Section of the genital caecum at the ovarian stage, Synapta inharens (chromic-aceticosmic solution of Flemming, safranini); $a$, amoebocyte of the genital lacuna; en, peritoneal epitheliu; $c v$, mass of yolk cells and indifferent spermatoagonia; lge, genital lacuna; $c g$, cavity of the caecum (specimen collected at Roscoff, 20 Dember 1890). Mag. 900 times.

Fig. 78. - Developing eggs of an ovary of Antedon rosacea (osmic acid, distilled water); $c v$, yolk cells; $v$, grains of yolk moving into the protoplasm of eggs.

Fig. 79. - Schemataic of an adult Amphiura squamata; $b r$, bursal slit; $p$, Polian vesicle; $t$, stone canal; ov, ovaries; te, testes. Mag. 12 times.

\section{PLATE XXXI.}

In all these figures, the echinoderm rests on the aboral pole. The mouth is thus above. It is supposed projected on the horizontal plane. The median plane is the holothuroid plane, except in the spantangoids; $x y$, line indicating the plane of Lovén (plane of bilateral symmetry) if we have oriented the spatangoid like other echinoderms; an, anus; $m$ mesenterial septa. Most of these schematics are modifications of the analogous schematics of Ludwig (106). The dotted lines respresent the traces of the various planes of symmetry studied in the chapter on orientation. 


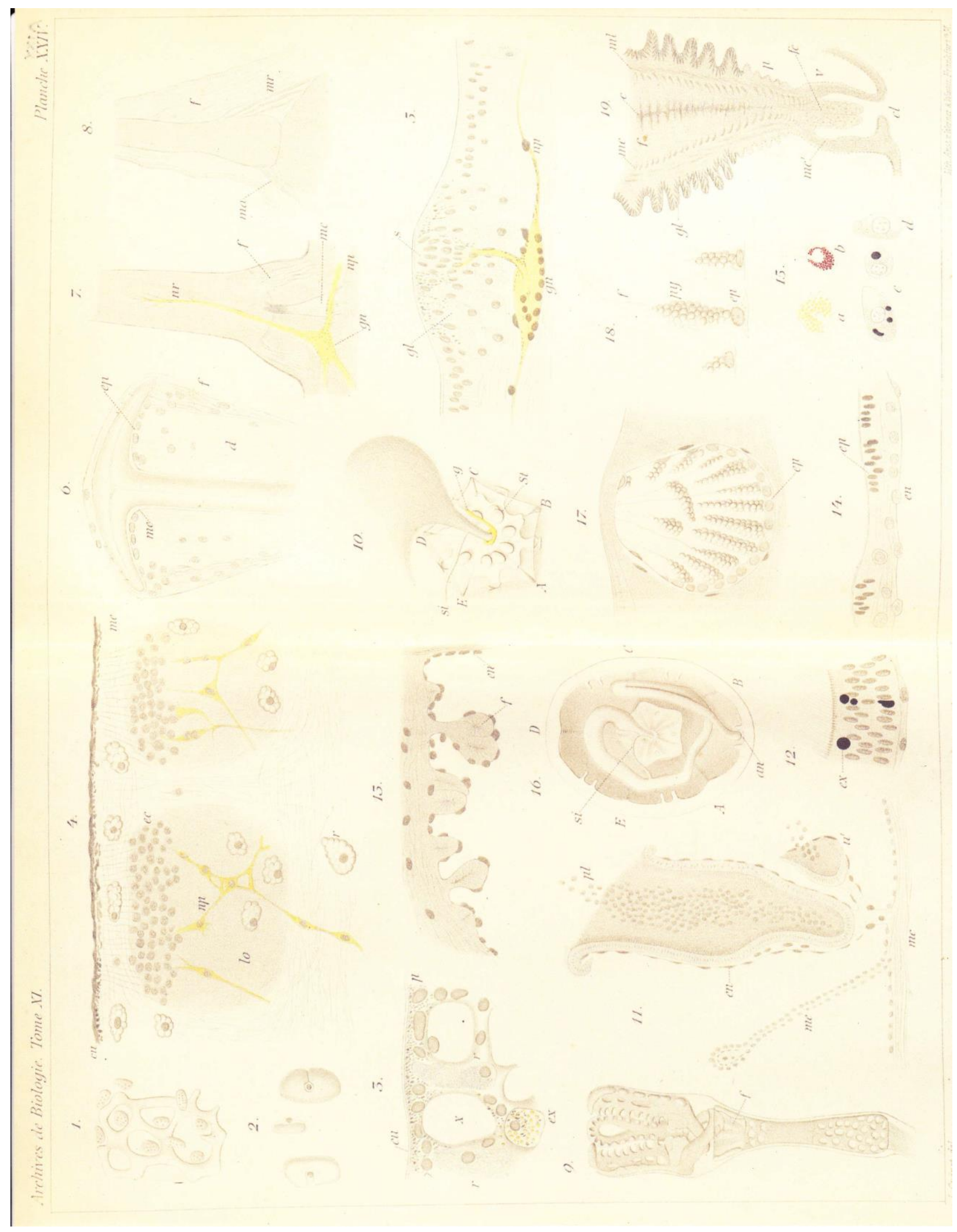









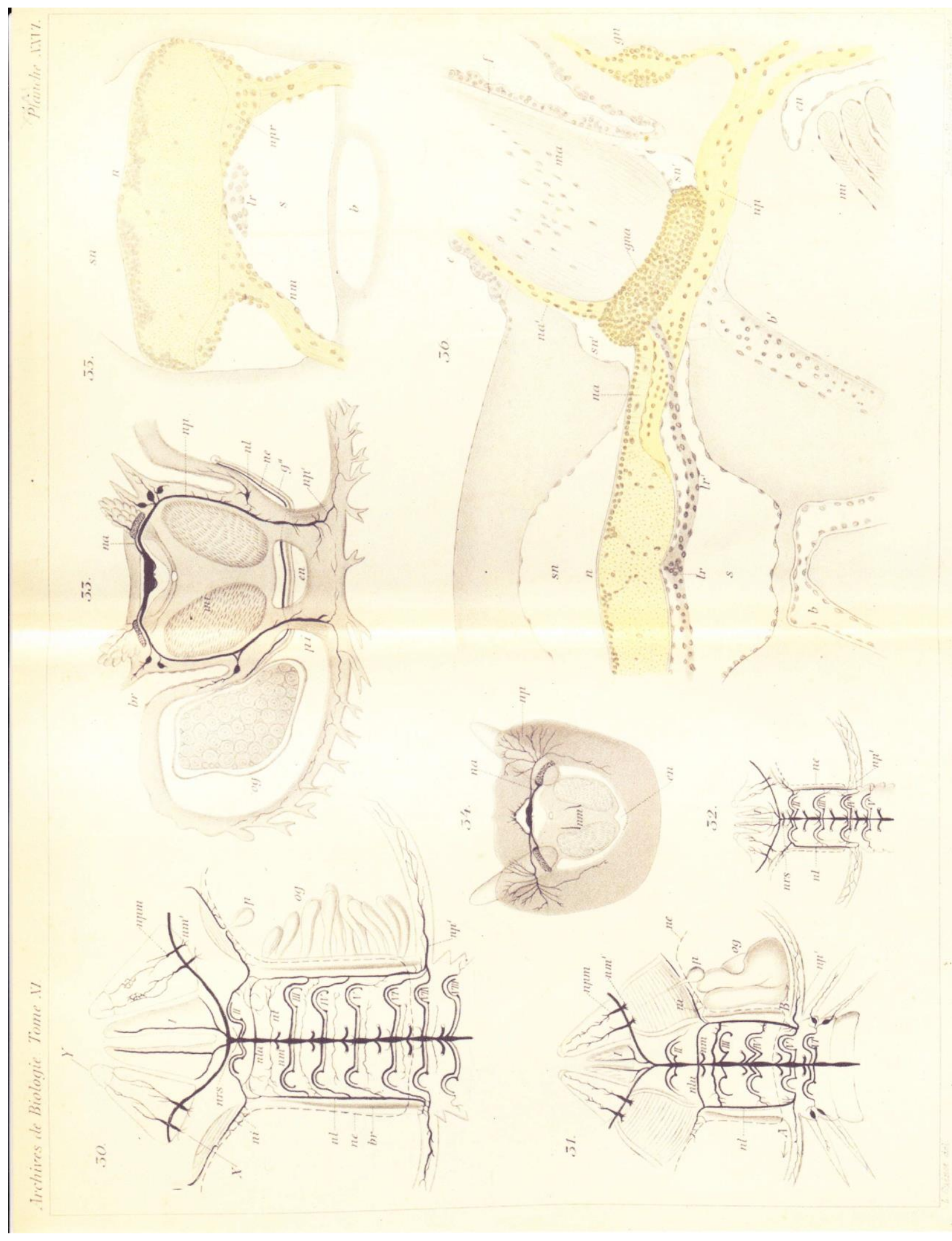




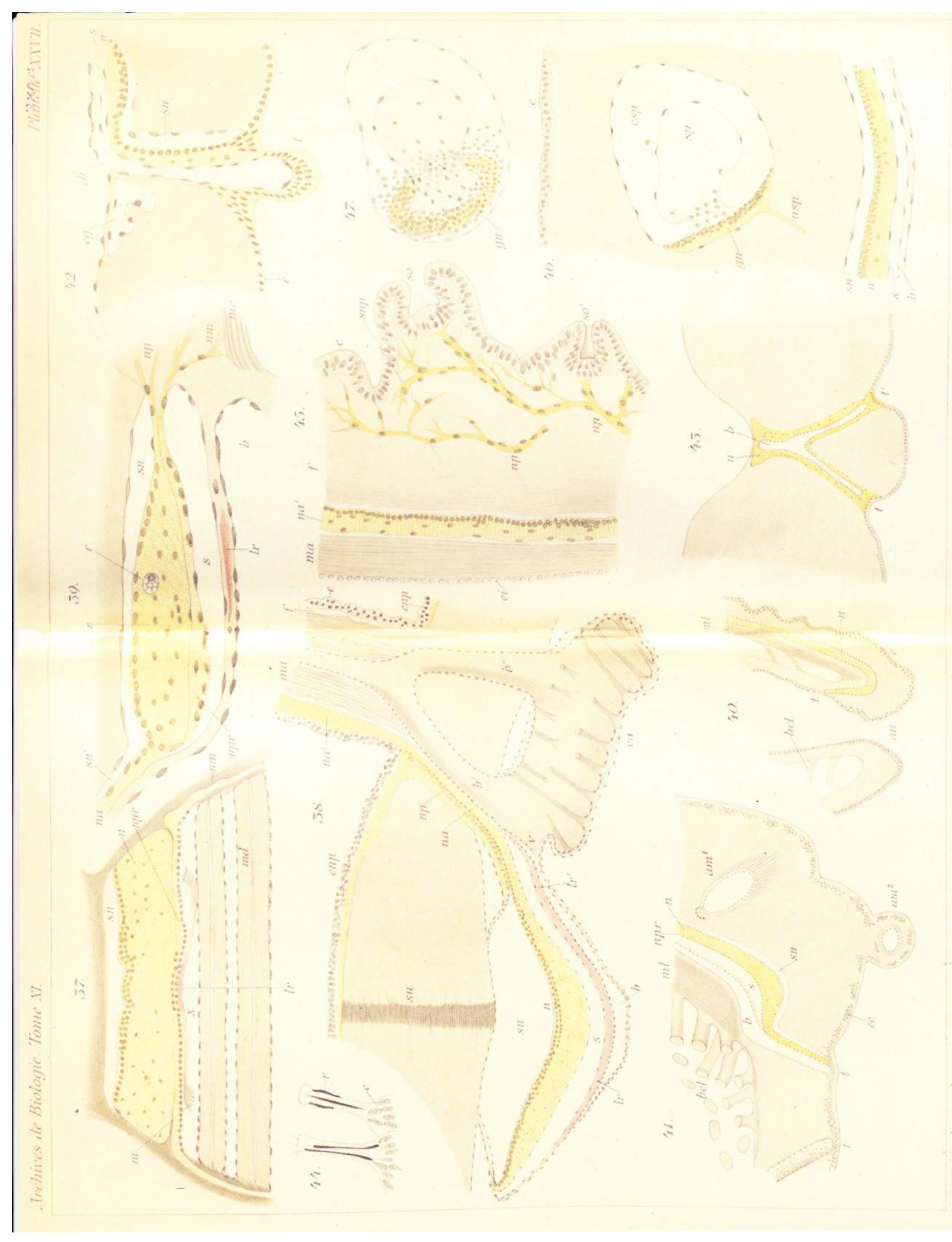









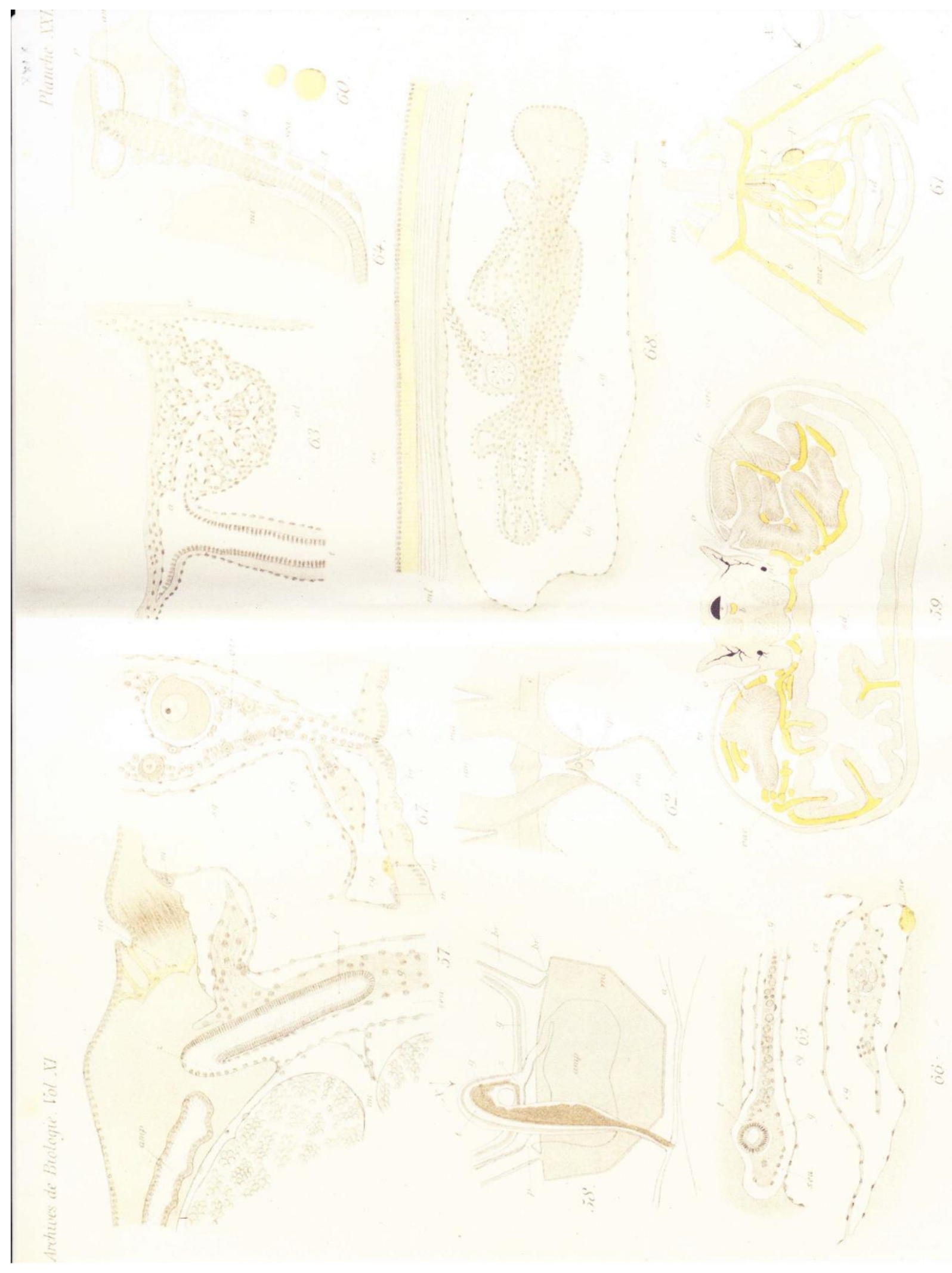




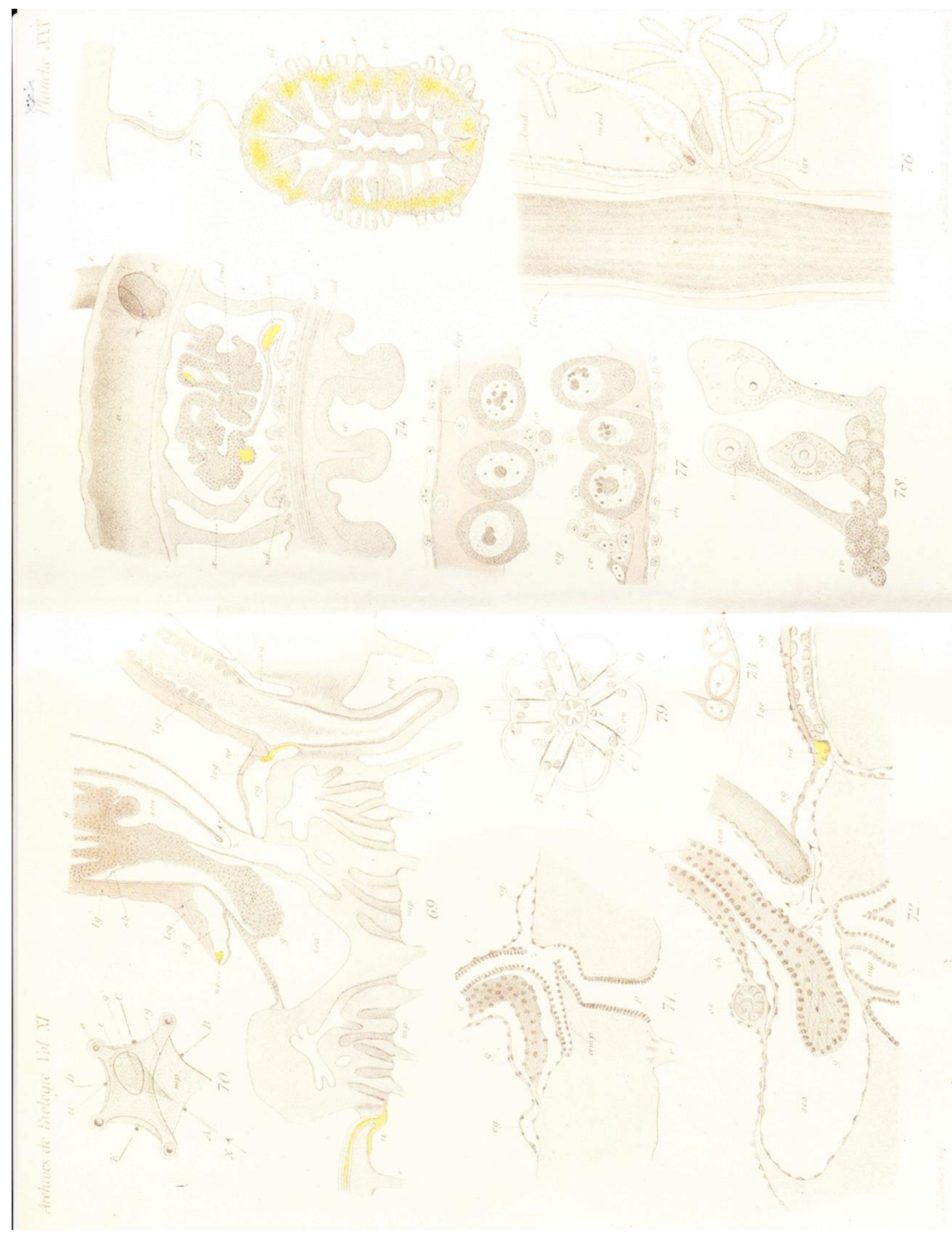




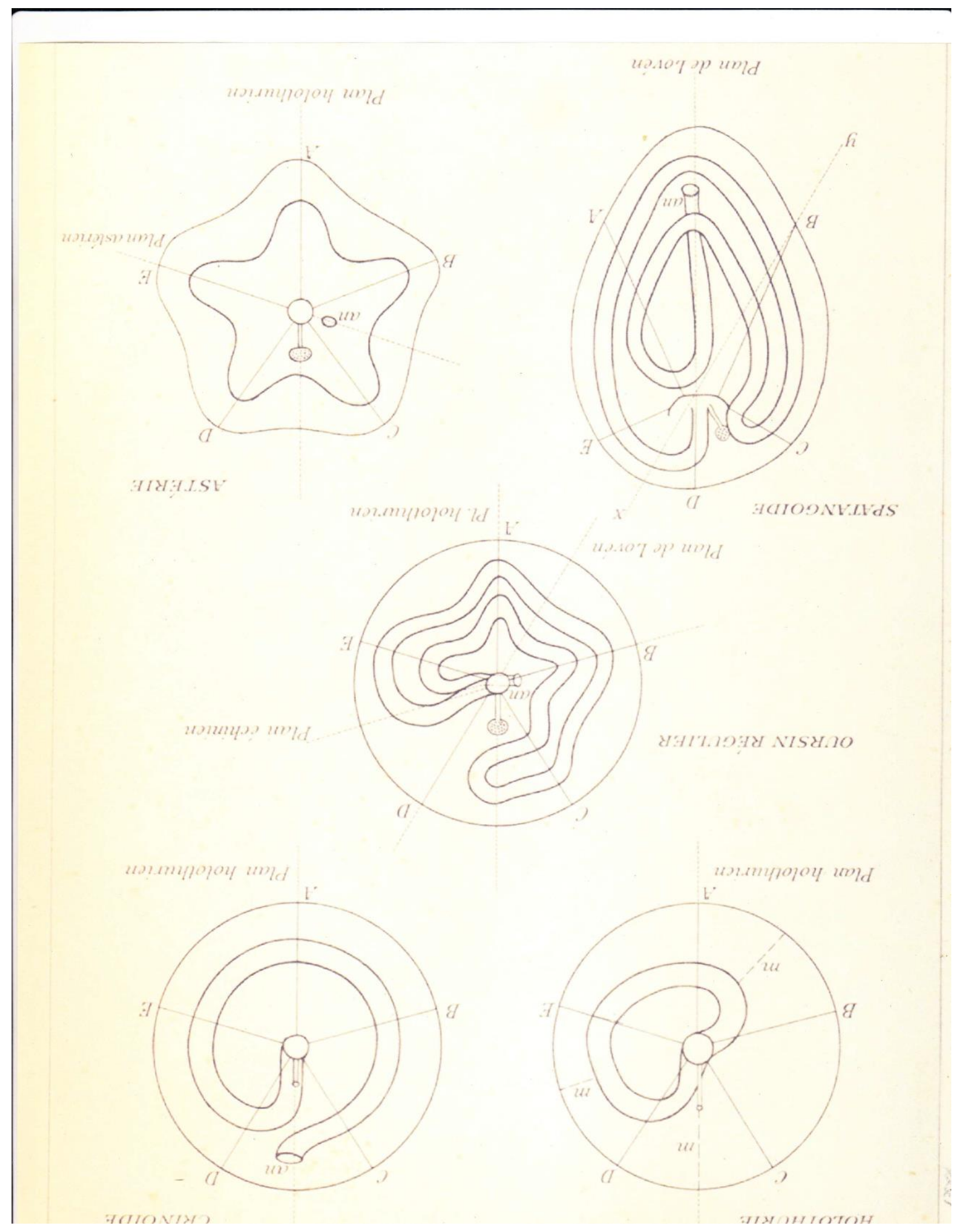


